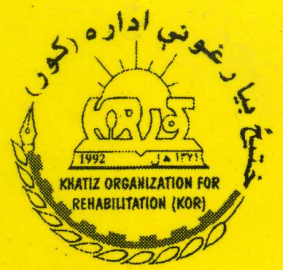

ختيخ بيارغونب اداره (كور)، خيرونو خانكه

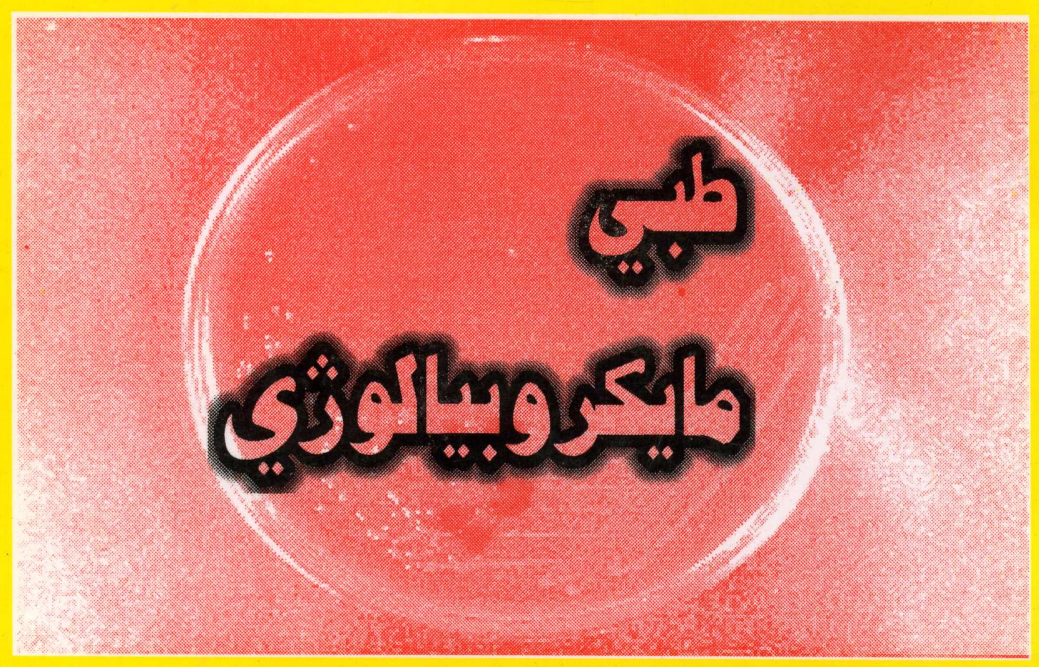

د منخخيو طبي زده كرو زده كوونكو لِاره

ليكوال: محمد عمر درمان

دطبي عالي تكالوزثىشف تككالوزيسن 

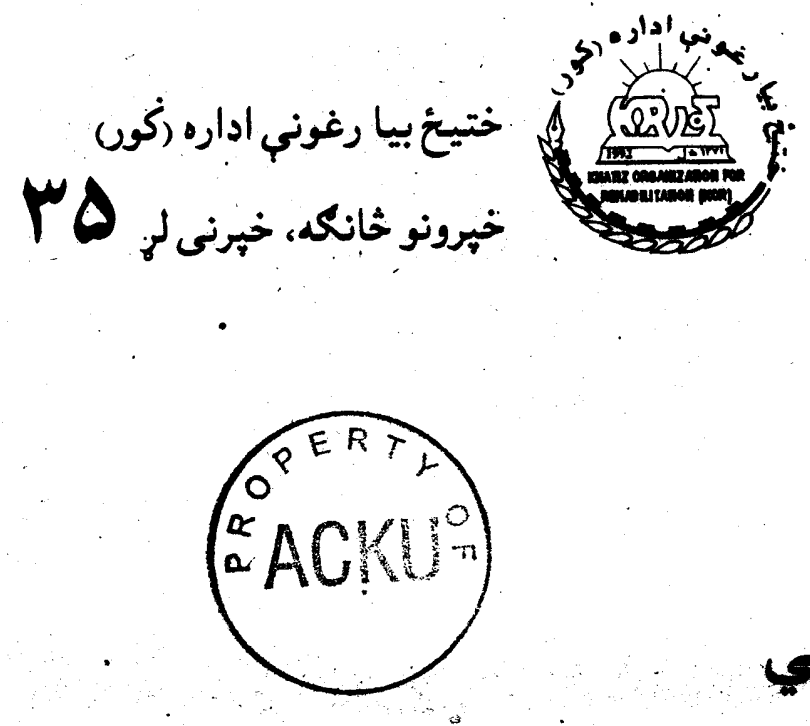

\section{هايكرو بايولوثي}

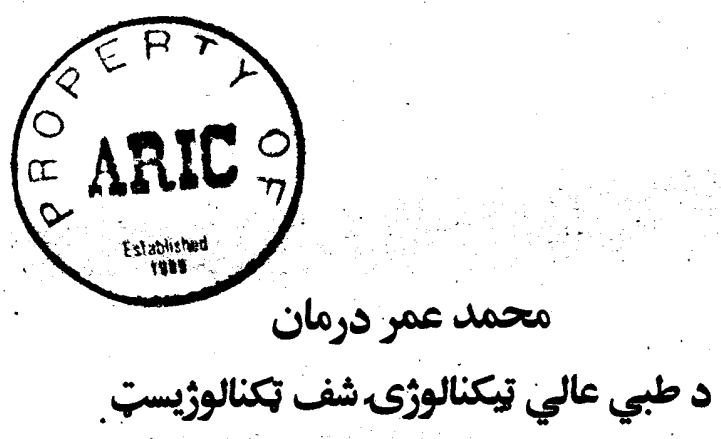




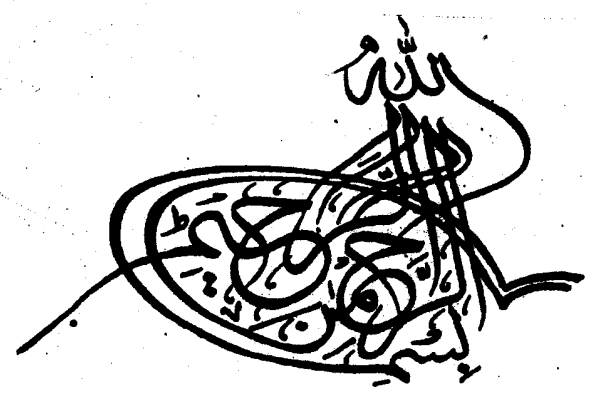

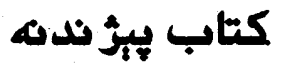
كتابنوم :طبي ميكوريبولوئي

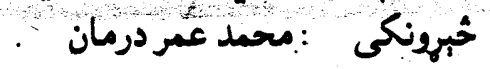
خبرونكى : ختئيبارغوني اداره كون تائي: حفيظ الذهراب

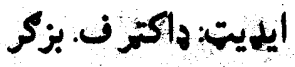

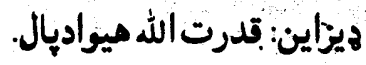

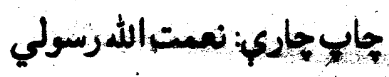
جابلكبنت : كور او اكتر ابن امين

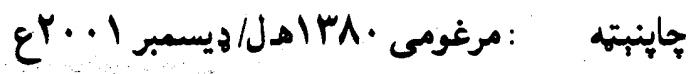

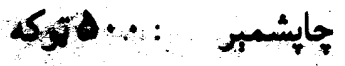
ro: : خيرنى له (C) د جاب تول حقوق خوندي نيا

زمور بته: GPO Box 607, Peshawar, Pakistan E-mail: kor_bazger@hotmail.com د ارتباط نوري يتي د كتاب به باى كي وكورئ! 


\section{من:لـ}

د ختبح بيا رغوني اداري" (كور) د محترمين اداري له تولو بنباغلو كاركونكو

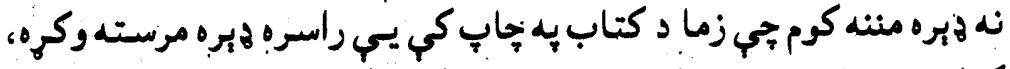

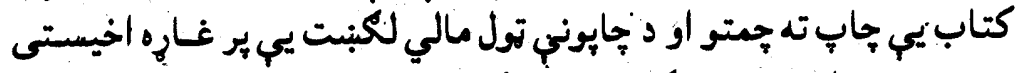

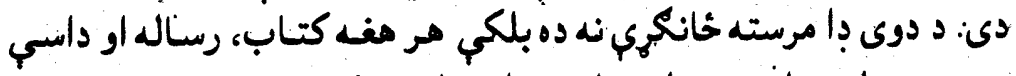

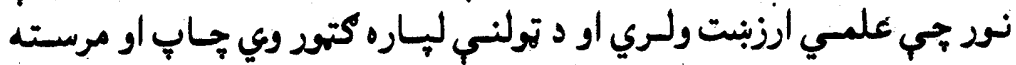

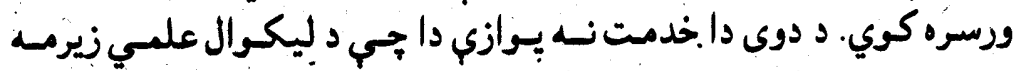

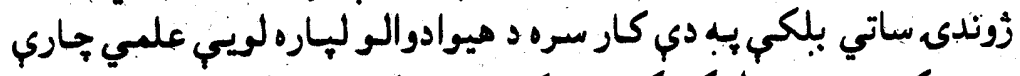

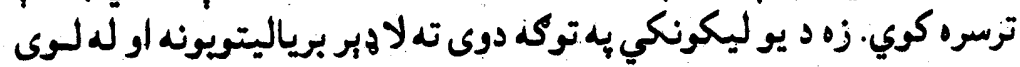

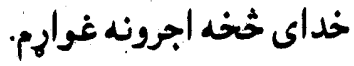

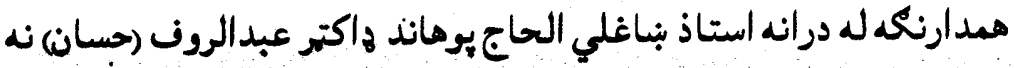

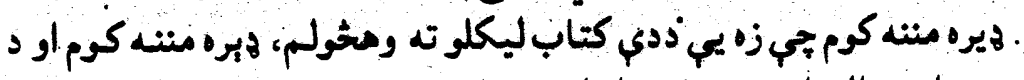

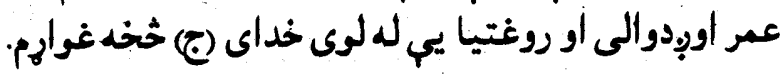
والسلام محمد عمر درمان د طبي عالي تكنالوذيى شبف تكنالوزيسبت دمان 


\section{سر لبكونه}

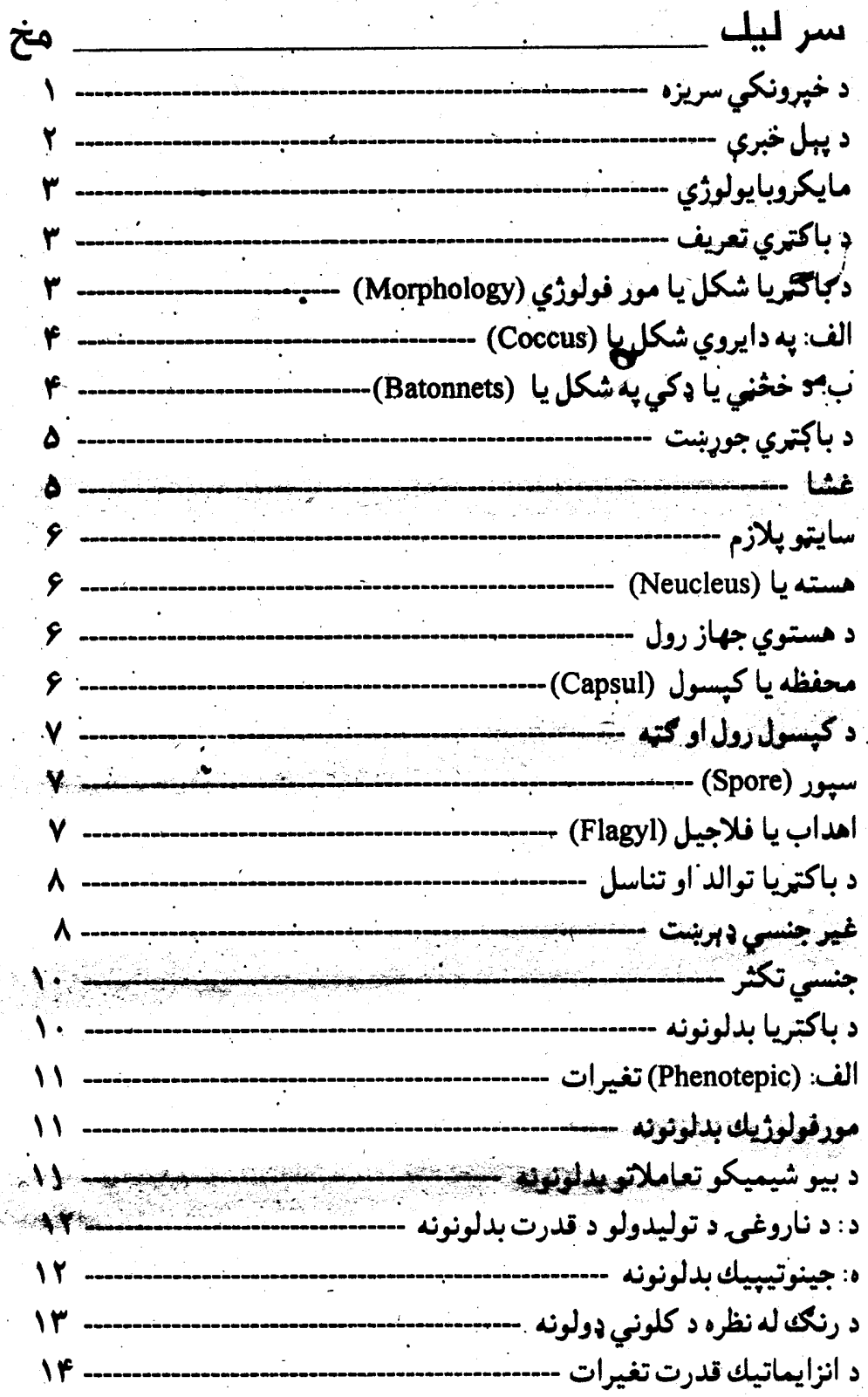




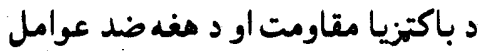

18 له باكتريوفاز سره حسناسنيت 19 ميبوتيشن (Meutation) د باكترياكانو فنيالوزئي 19

IV

IV

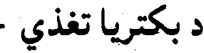
الف: مطلق اوتوتروف بكترياكاني in

in

in in

IA ب: ميزوتروف بكترياكاني (Mezotrophe)

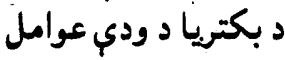
in 'د نشونما عوامل حقيقي منبد ودى عوامل

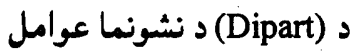
$r$

$r$. (Burning method) سوخهدو به طزيقه تعقيم يا $r$. م شعله وركوبو ميتود يا (Flame Method)

$r$.

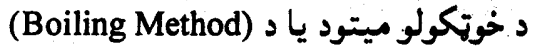

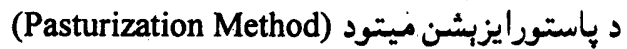

YI

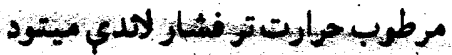

Yr د كيمياوي موادو د استعمال ميتود rY

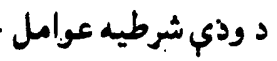
(Strielization) تعقيم ياميا

r. $r \cdot$

M. (n) 
P ر 1

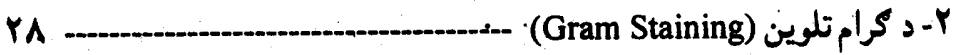

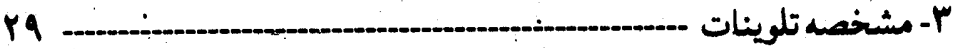

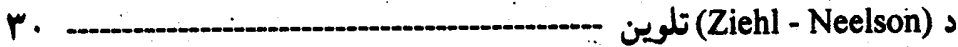

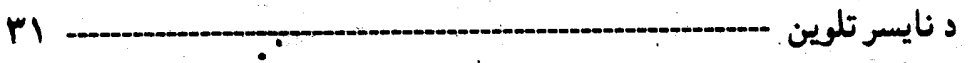

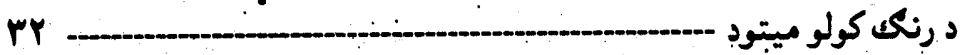

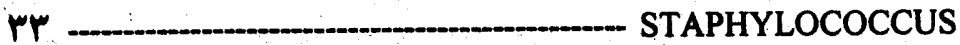

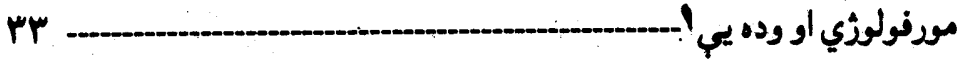

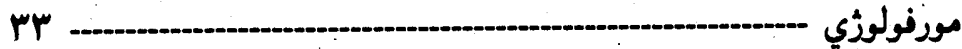

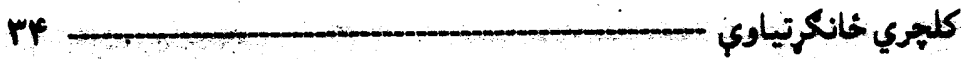

rF. د ستفيلوكوك اوريس متاومت

ro

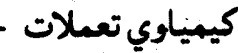

ro مولدالمرضي خانكرتياوي

ro د ستفيلو كوك اوريس انزايم او توكسين

rV

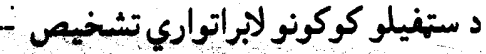

PV

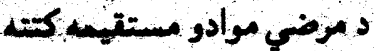

rV ج كرام تلوين سامان او ريجنيت يني ميني

rV د تلوين ميتبوة

rA

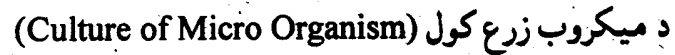

لد كله rq ئ

Fr ستزيبتو كوكونه (Streptococcus)

Fr مورفوليزي مئي FY د متريتو كوكو ويشنه

tit

Pr شكري تخمرات - pr Bile solability fr Heat resistance

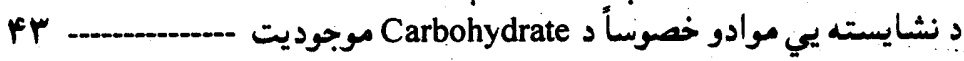




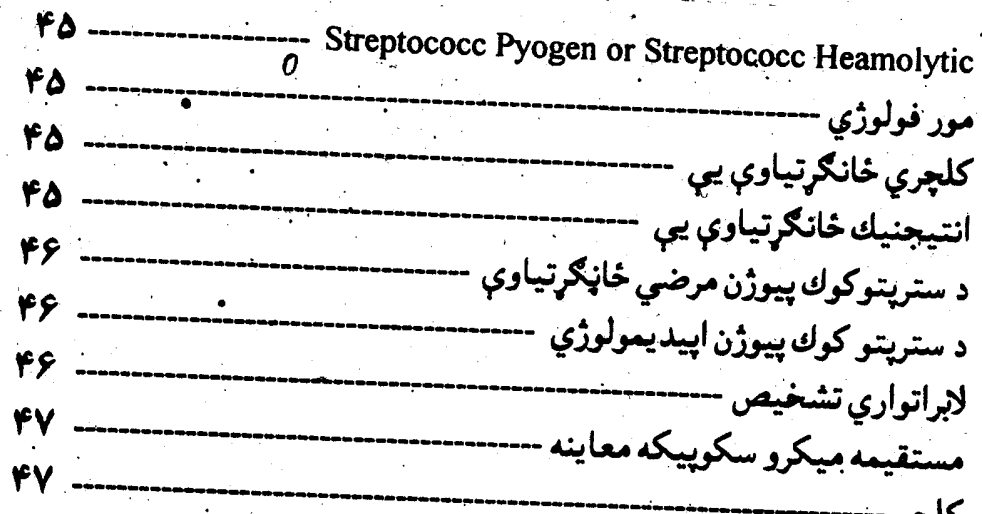

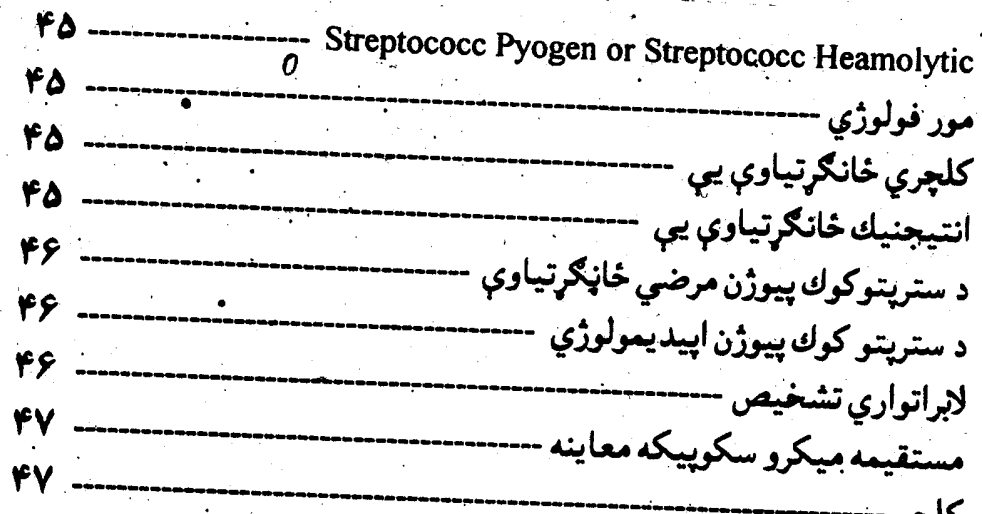

$\Delta r$

د ستريتو كوك يولونبه

نموكوكونه (Pneumococcus)

$\Delta r$

or

$\Delta r$

مورفولوزي

د نموكول اتتي جينيك جورينبت د نموكوك مرضي كانكرتياوي

$\Delta r$ لابراتواري تشخخيص ييب

$\Delta P$

$\Delta \Delta$

$\Delta 8$

$\Delta 8$

مستقيسه كتنه

حيواني تلقيح (به موبِكانو كي)

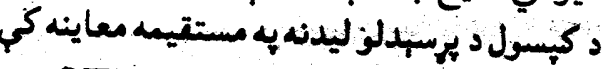
د د د ديسيريا كروب (NEISSERIA GROUP)

$\Delta$

$\Delta v$

$\Delta V$ د د نايسريا د كروب مود فولودئي او تلوين

$\Delta A$

$\Delta A$

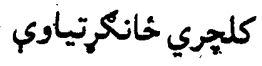

$\Delta \wedge$

$\Delta A$

كبمياوي تعاملات

$\Delta q$

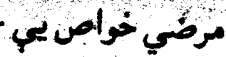

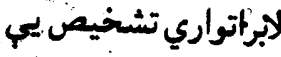

مستقيمه معاينه

د كونو كوك كلجر

د تيستب د اجرا مبتود كون

$\Delta 9$

منيكوكوكونه (Meningococcus)

s.

\section{كلجزي خواص يبي}

شكري خواص 


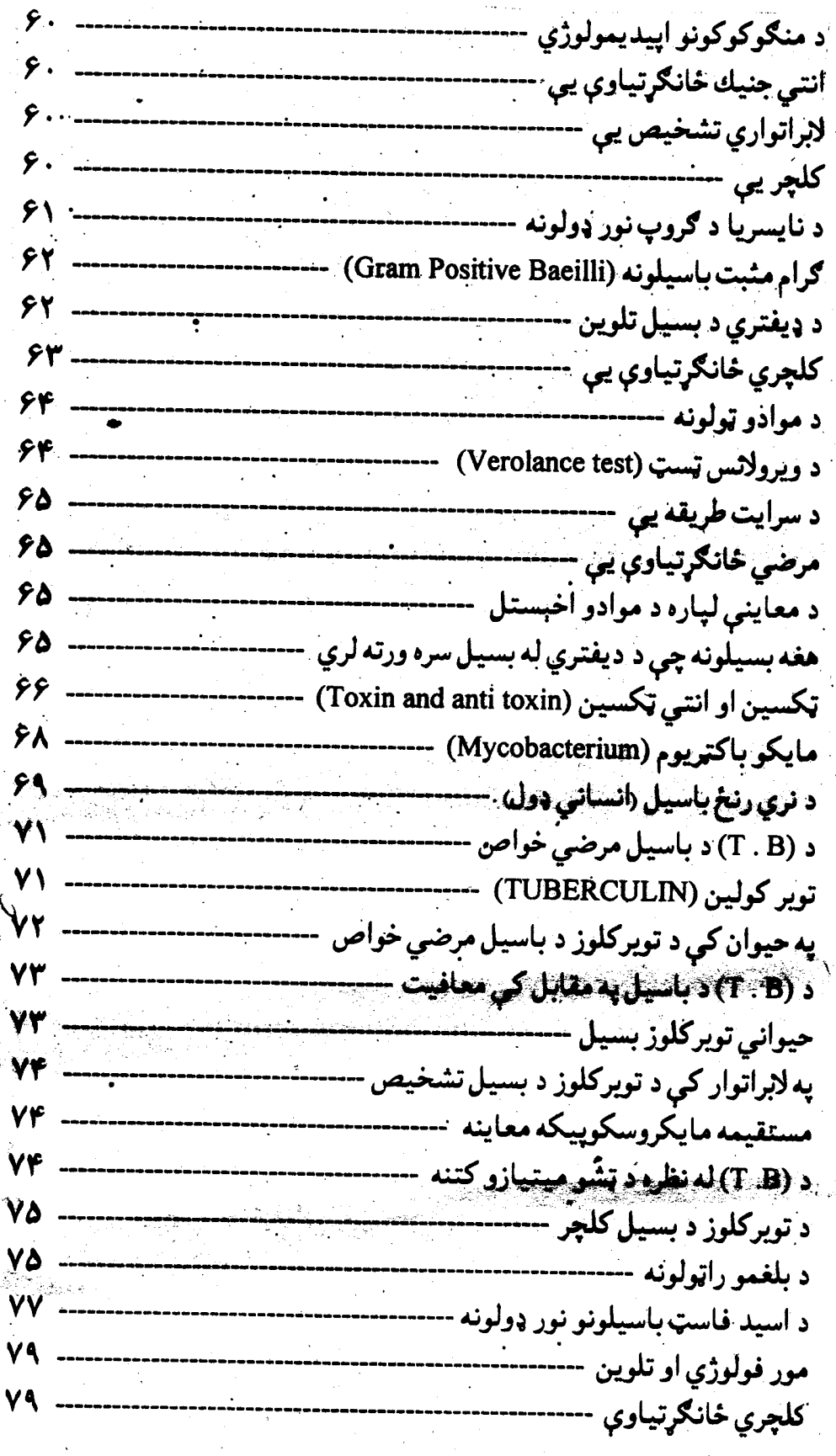




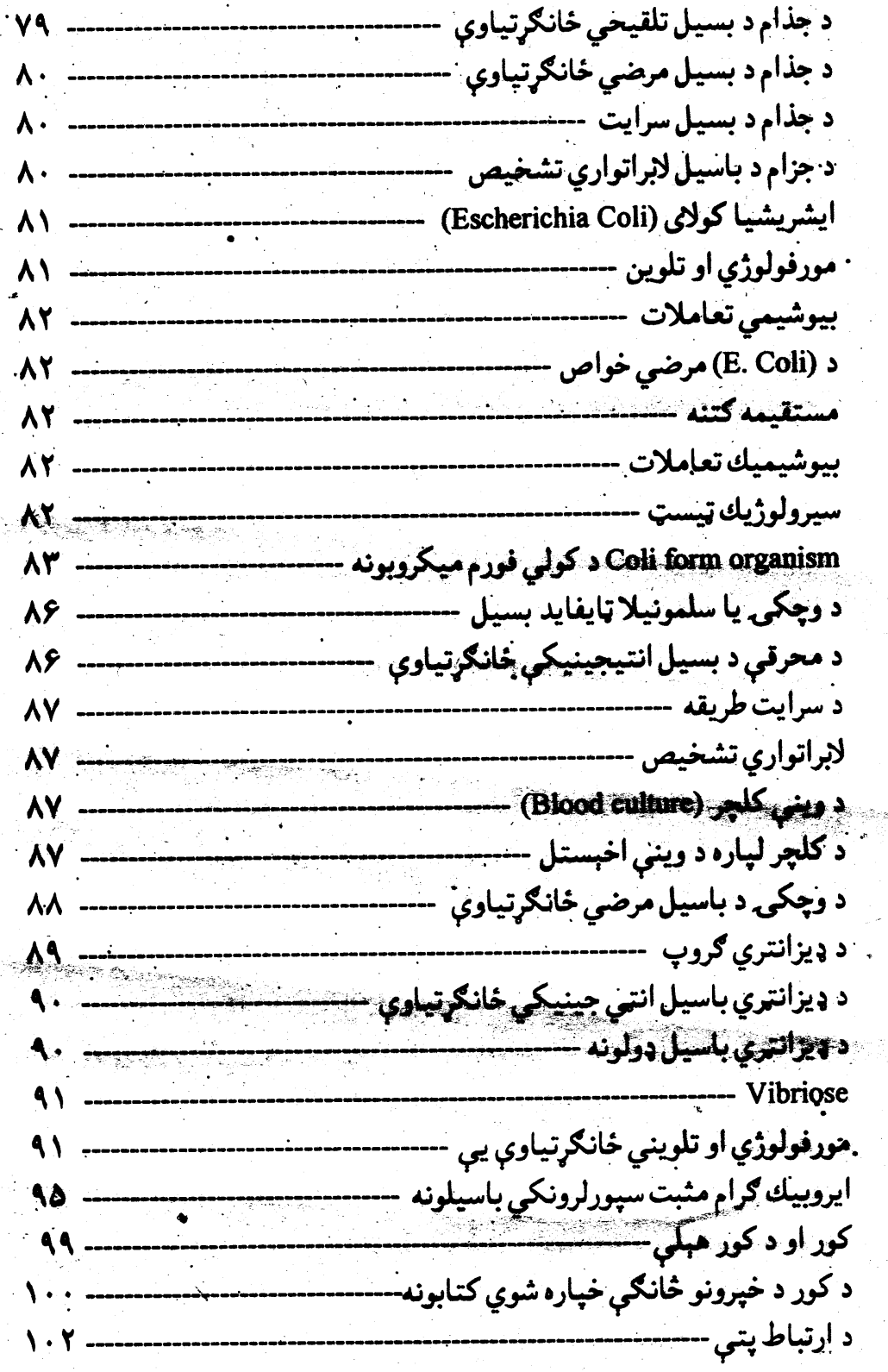




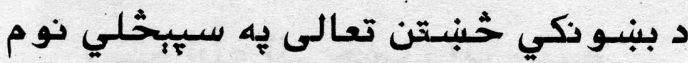

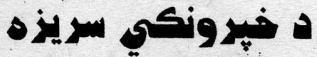

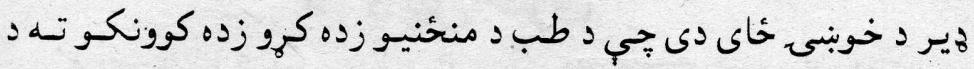

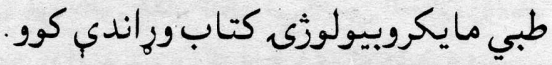

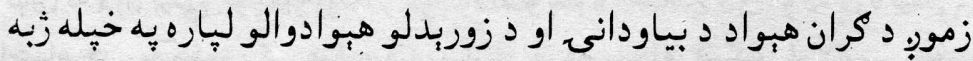

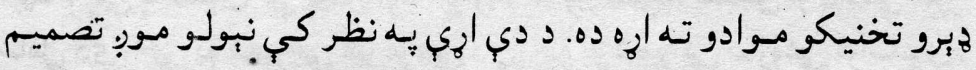

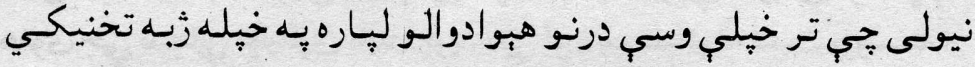

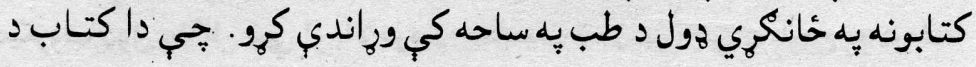

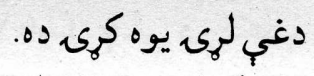

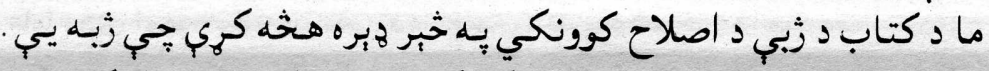

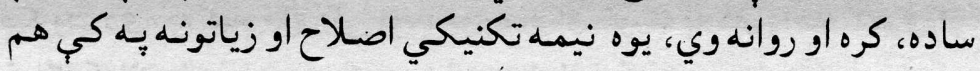

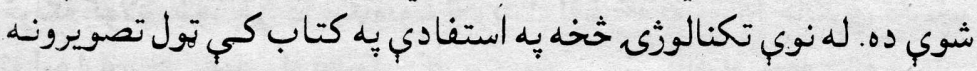

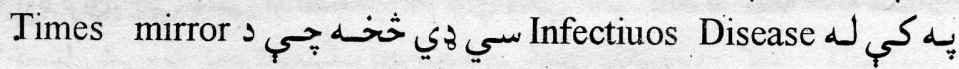
company

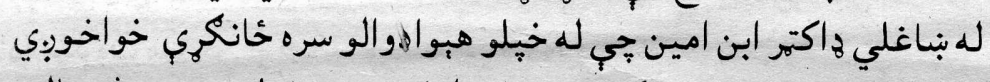

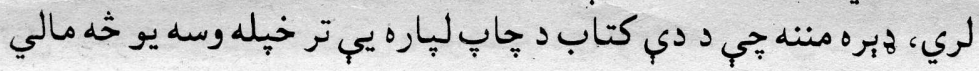
مرسته برابره كرها

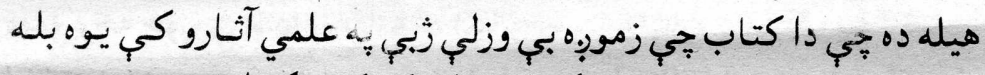

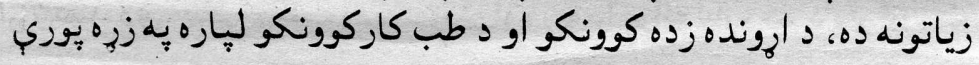
او و هغوى د استفادي ورن وكرخي.

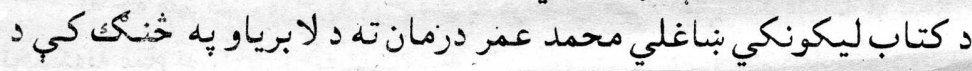

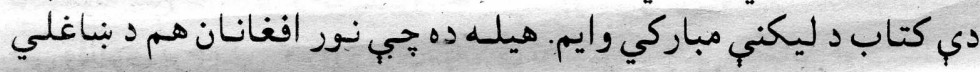

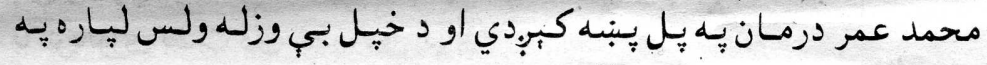
ارونده رشتو كي كتابونه او آثار وليكي.

خورا درنبنت

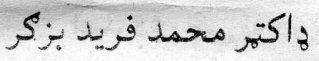

ن ختيز بيارغوني اداري (كور) مشر فريد 


\section{بسـم الله الر حمن الر حيهم}

\section{د بيل خبري}

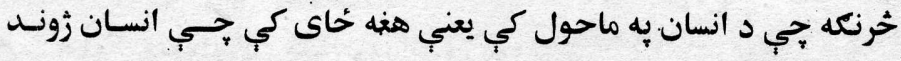

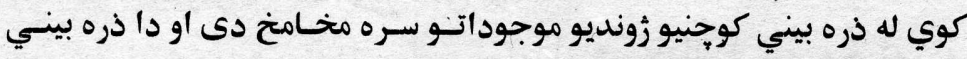

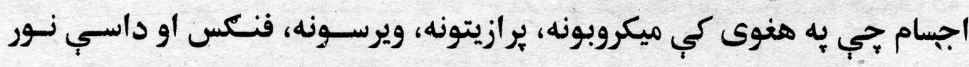

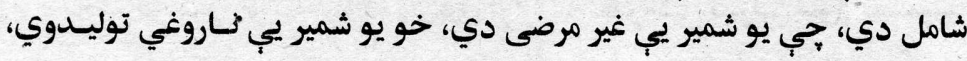

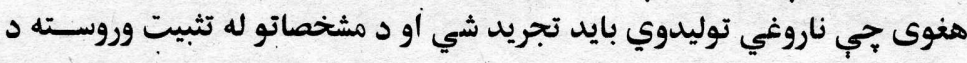

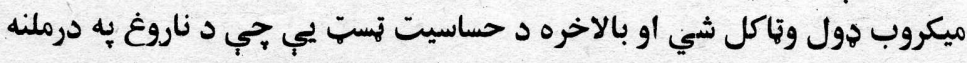

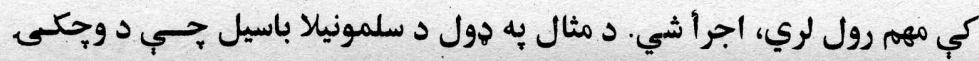

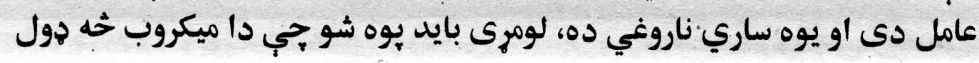

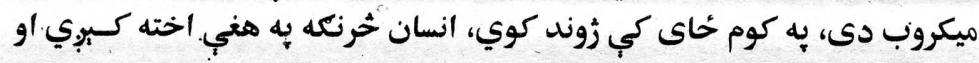

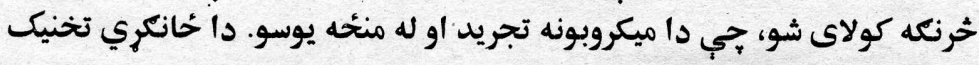

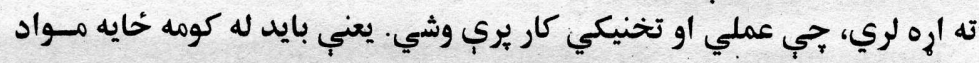

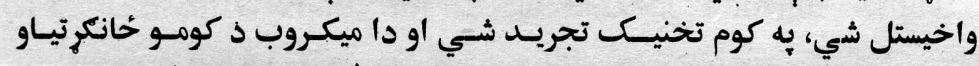

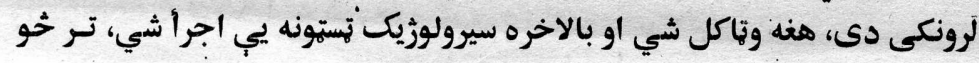

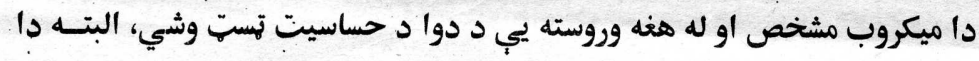

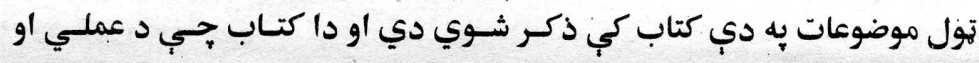

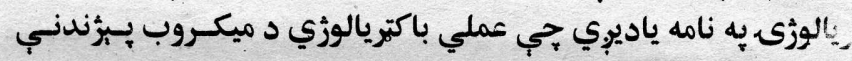

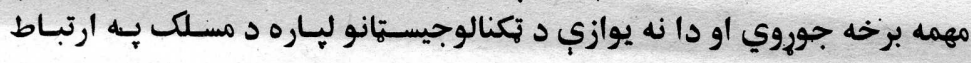

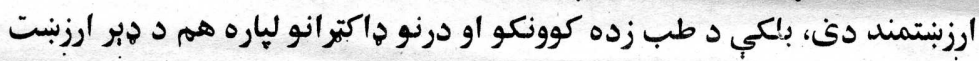

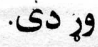

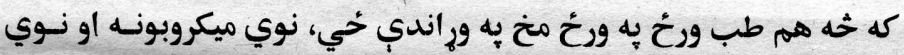

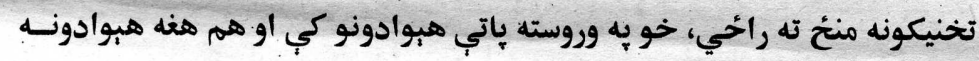

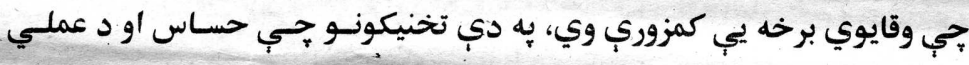

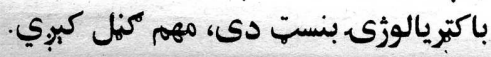

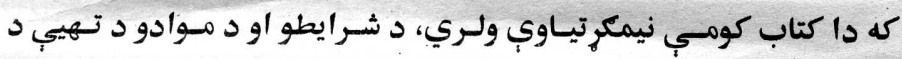

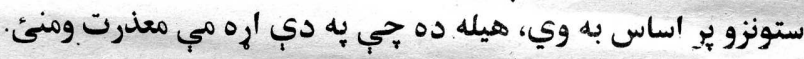

$$
\begin{aligned}
& \text { اميد دى جحب له دي كتاب خخخه بنه استفاده وشي. }
\end{aligned}
$$

درناوى 


\section{بسم الله الرحمن الرحيم}

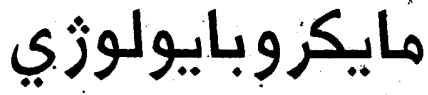

ذ مايكر بايولوزي تعريف:

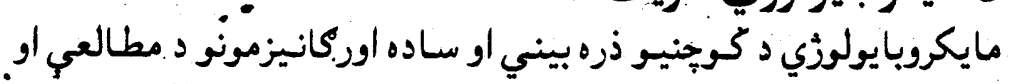

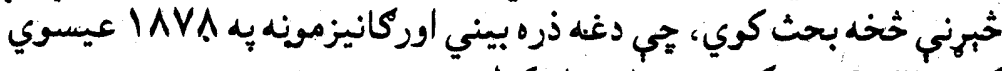

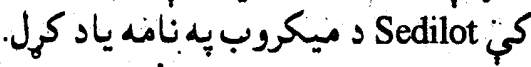

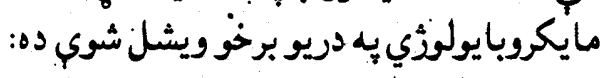

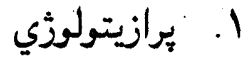

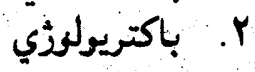

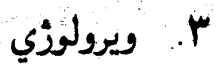

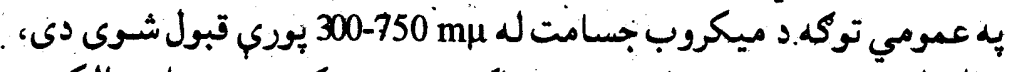

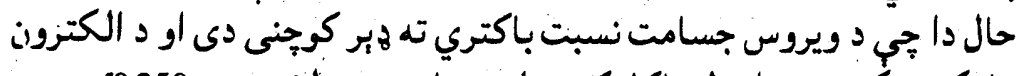

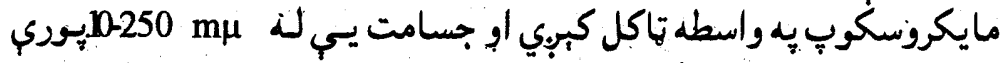

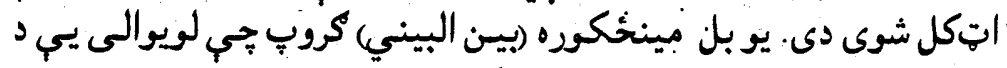

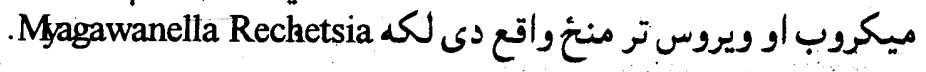
د باكتري تعريفي

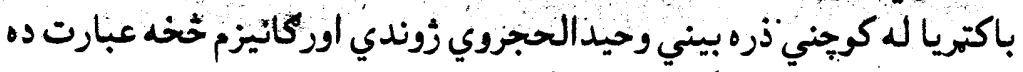

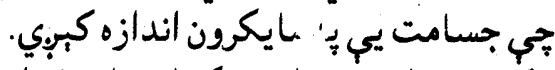

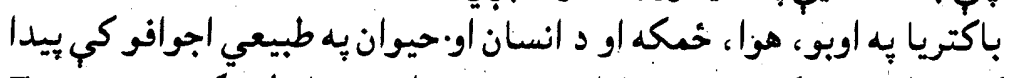

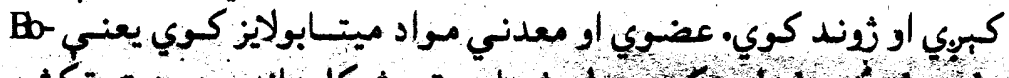

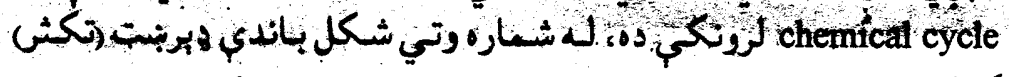
كوي.

د دباكتريا شكل يا مورفولوزي (Morphology):

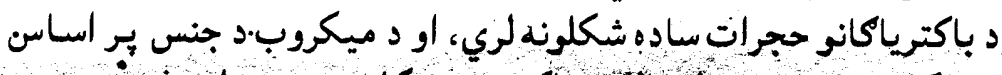

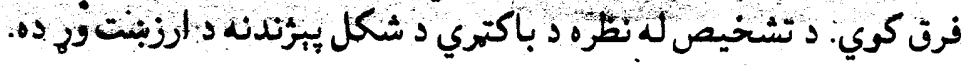

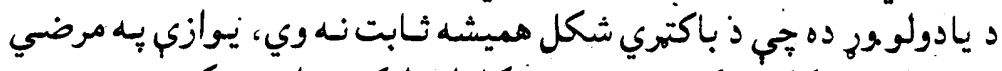

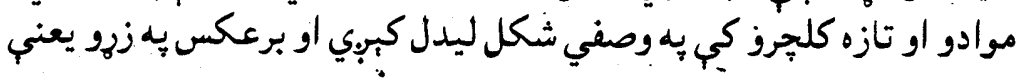




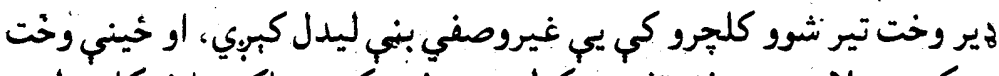

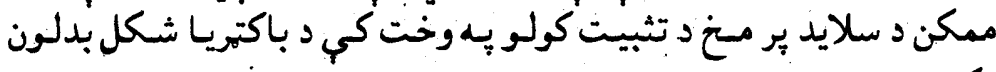
وكري. ميكرويونه د شكل له نظره به لالدي هولونو ويشل شوي دي:

:Euobacteries - 1

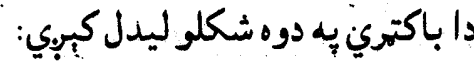
الف: به دابروي شكل يا (Coccus):

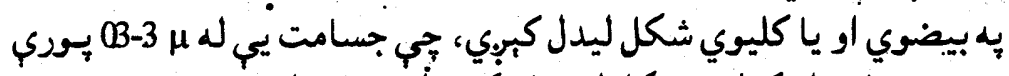

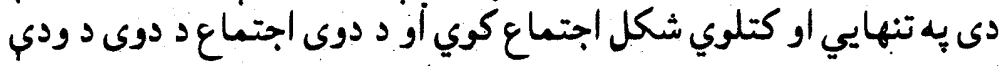

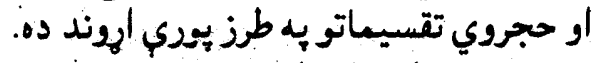

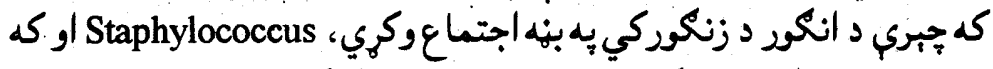

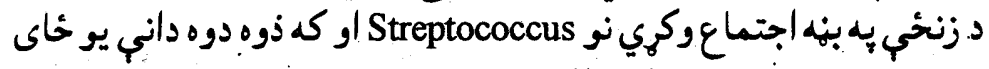

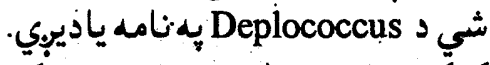

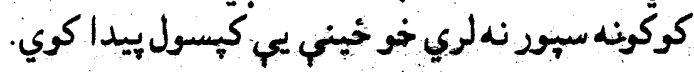

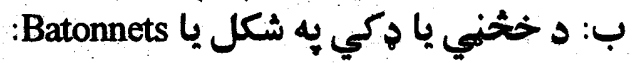

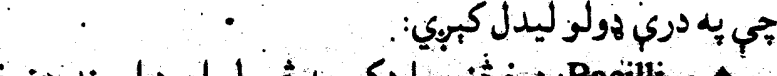

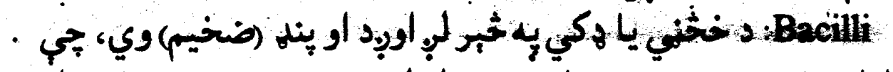

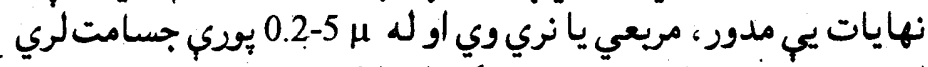

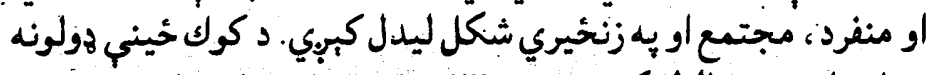

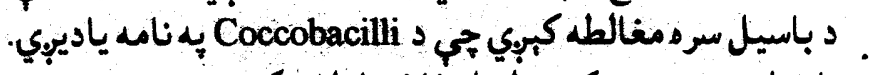

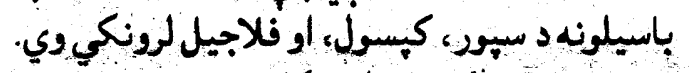

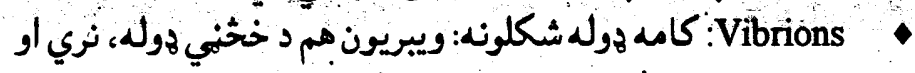

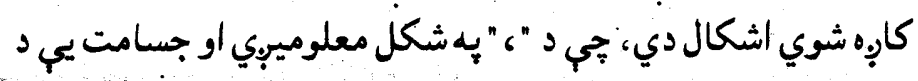

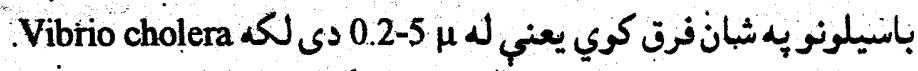

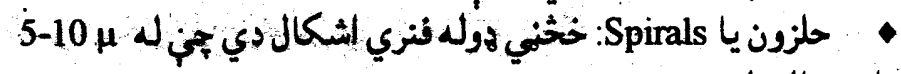
اوبجدوالى لري. :Miycobacteries - $r$ يه منتئيم يا Batonnet يا لو مدحدب شكل ليدل كبري لكه مايكوياكتريوم تويركلوز او.مايكوياكتريوم لبر. 


\section{:Protozoares $-r$}

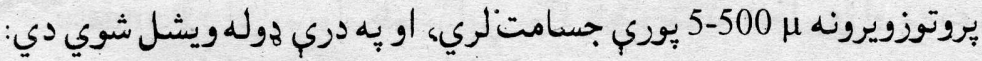

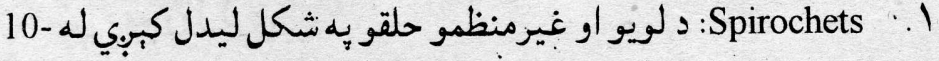

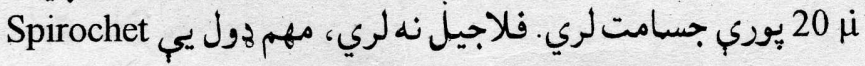

recorrents

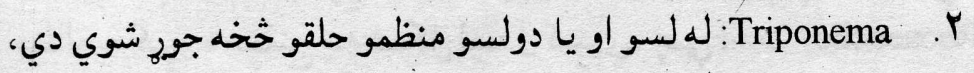

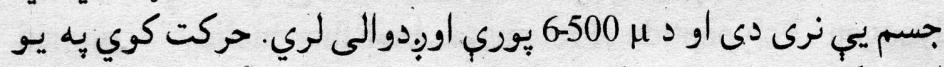

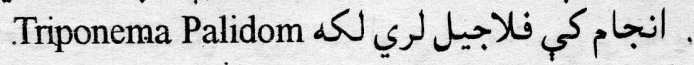

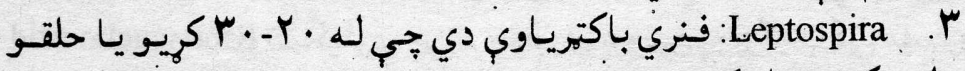

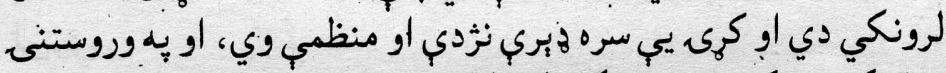

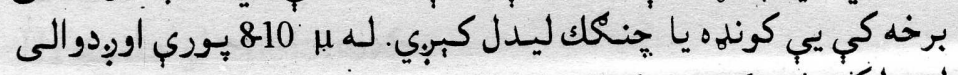

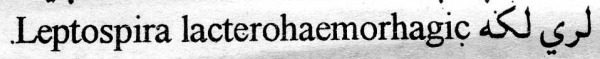

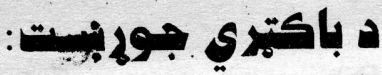

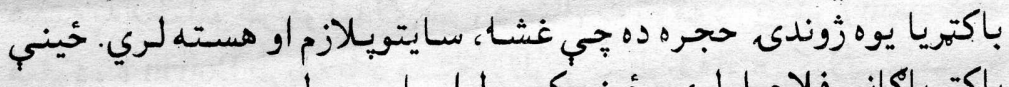

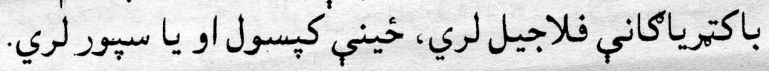

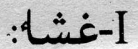

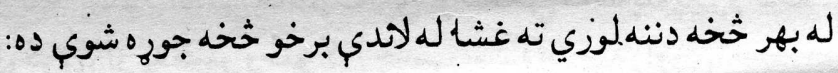

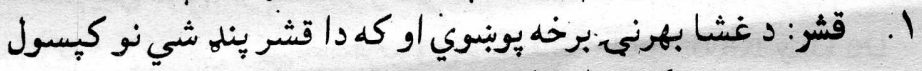

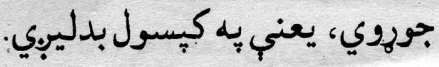

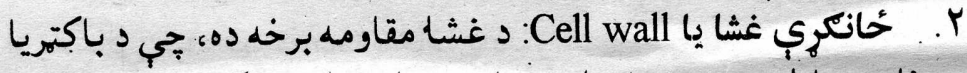

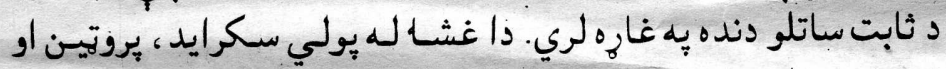

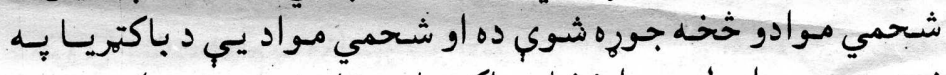

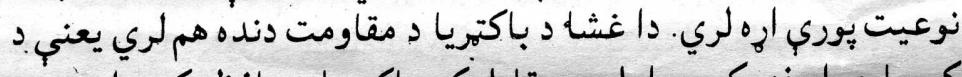

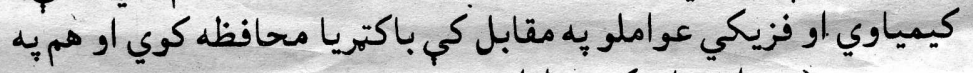

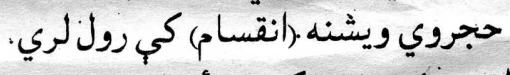

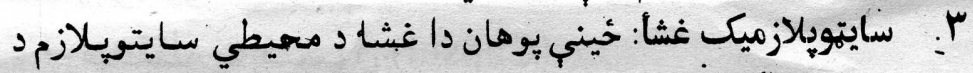

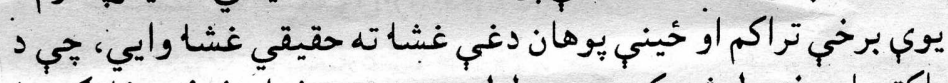

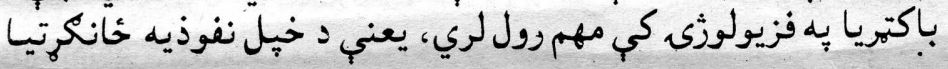




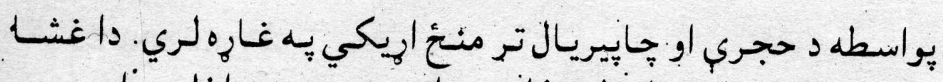
Permiase

$$
\begin{aligned}
& \text { كي مهم رول لري. } \\
& \text {-II }
\end{aligned}
$$

سايتوبلازم Coloìdal لري او و الكترونيك مايكروسكوب بو بواسطه يبي كه

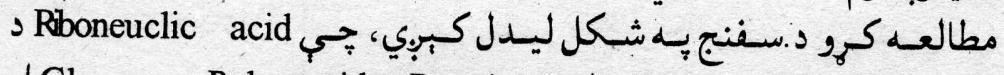
| مغلــRiboneuclic protied

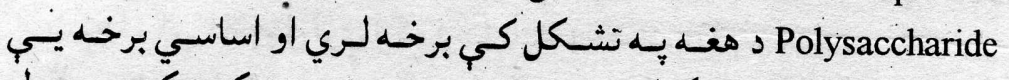

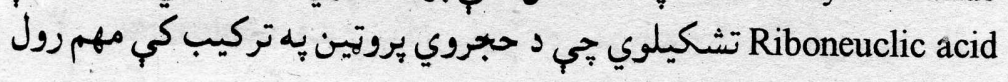

\section{لويوي. \\ :Neucleus هسته يا III}

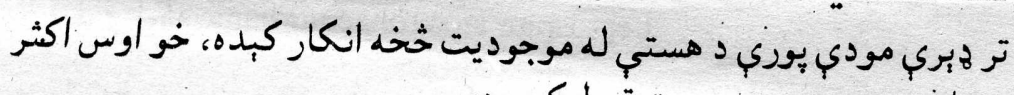

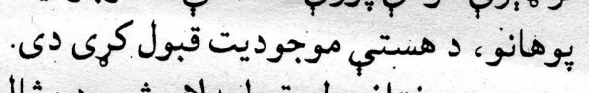

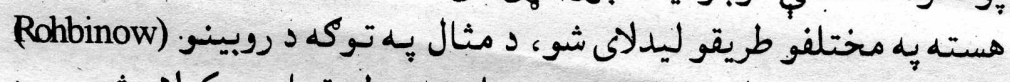

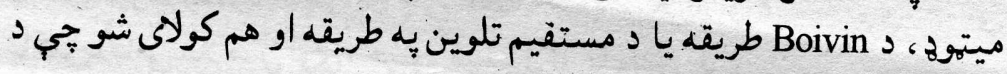

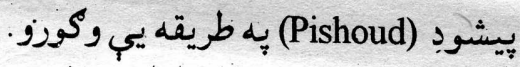

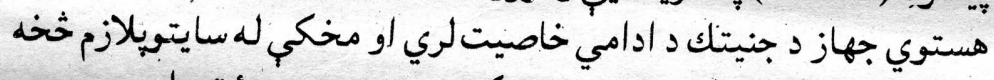

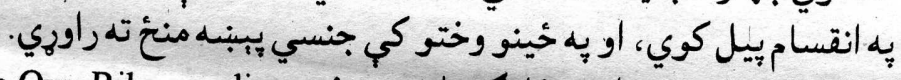

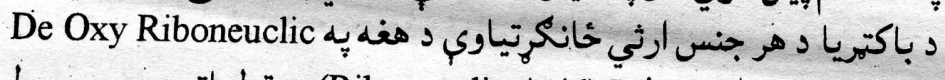

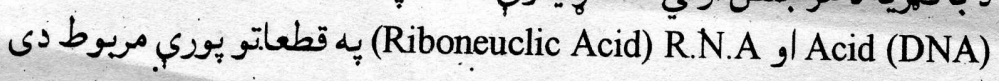

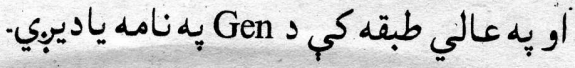

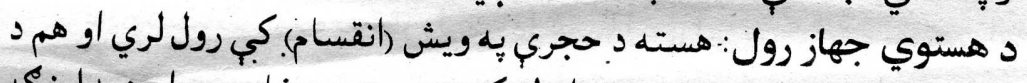

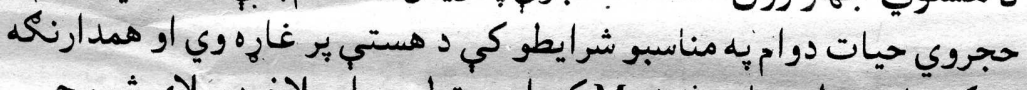

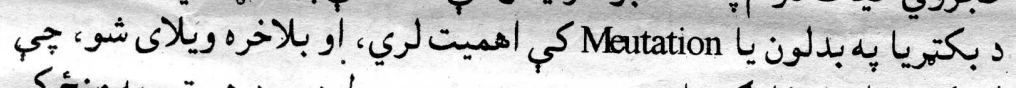

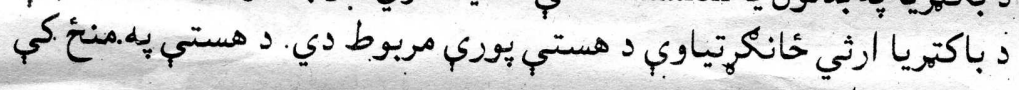
Gen (Capsul) محفظظه يا كيسول -IV

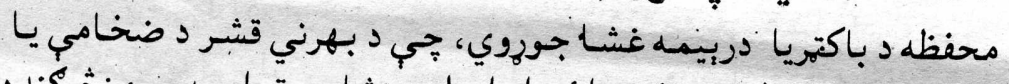
خicogelatinus 


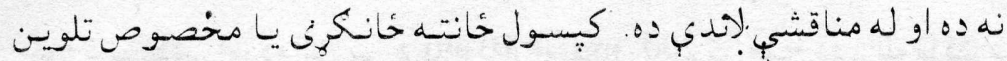

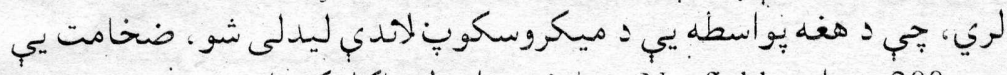

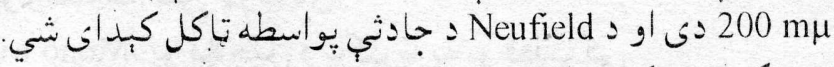

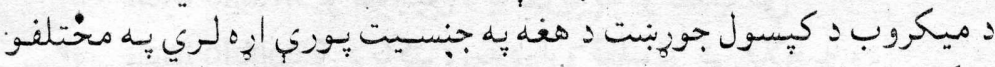

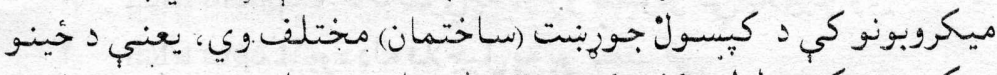

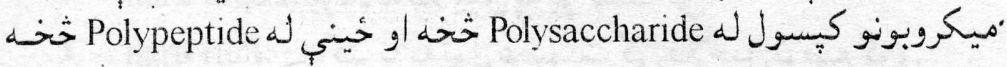

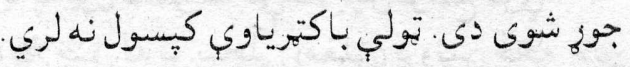

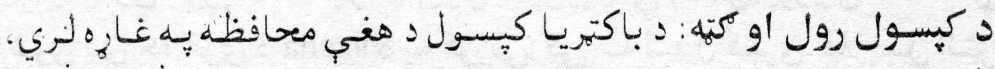

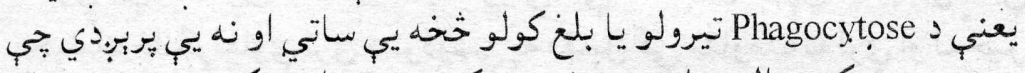

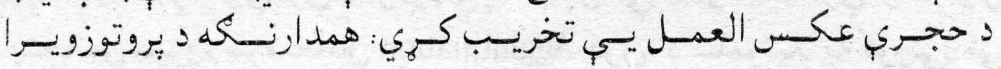

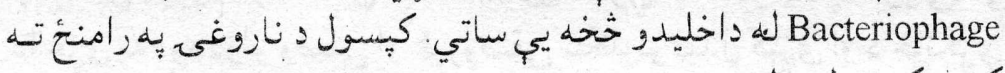
كيدو كي زول نه لري.

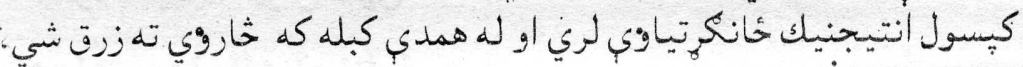

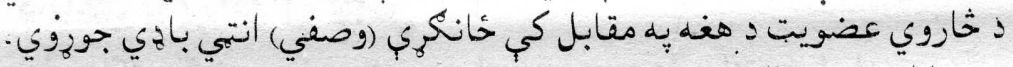

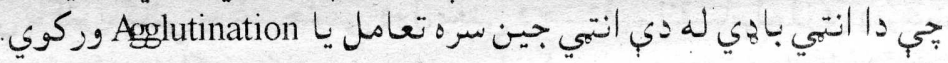

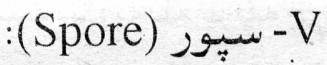

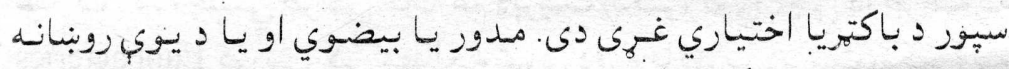

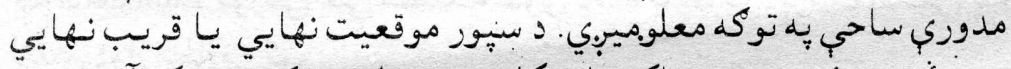

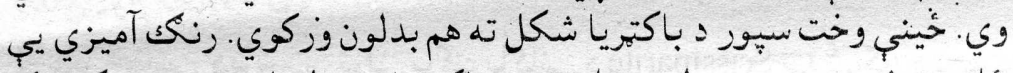

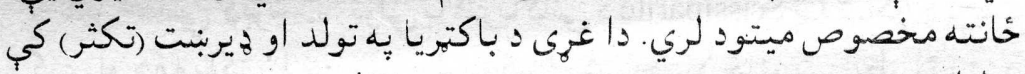
رول بري.

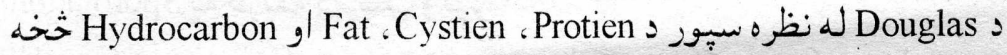

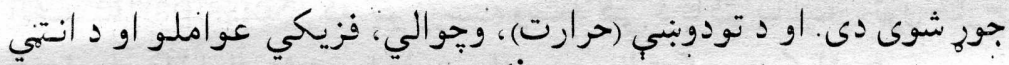

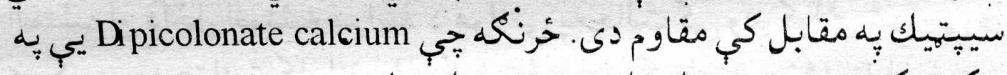

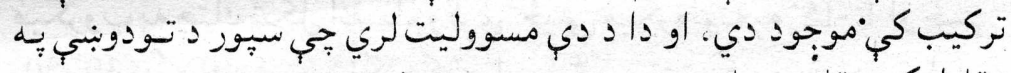
مقابل كي مقاوم وساتي.

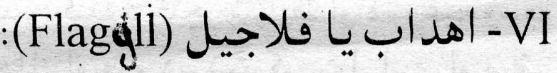

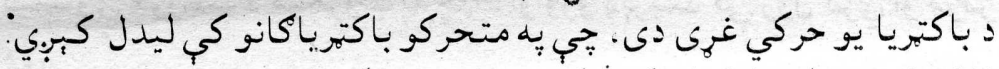

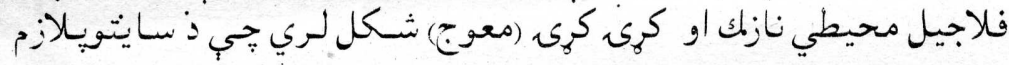




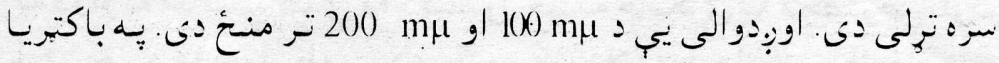

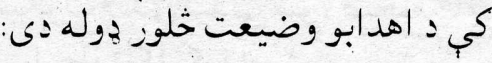

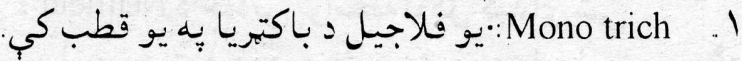

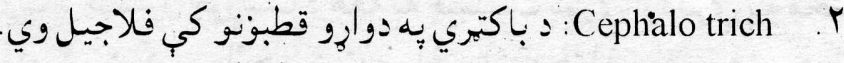

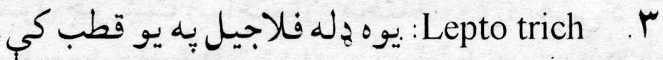

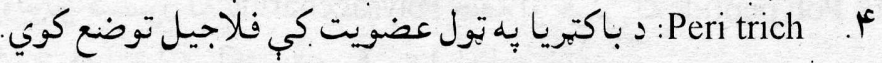

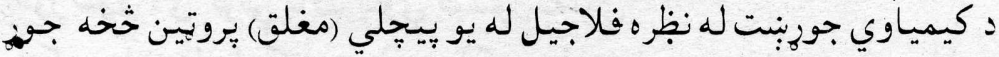

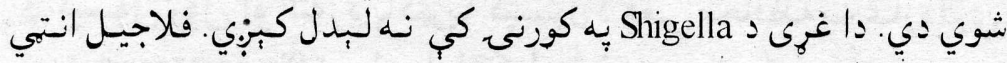

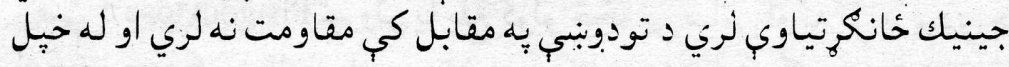

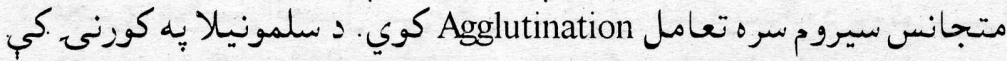

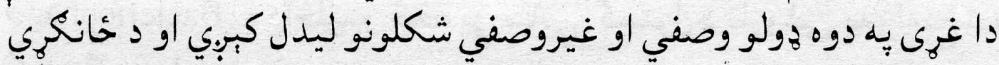
ميتبود بِه وسيله تلوين كبوبي.

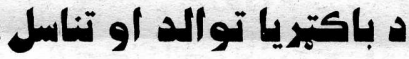

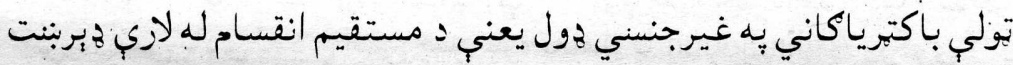

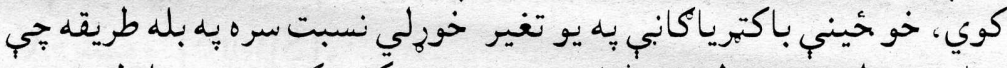

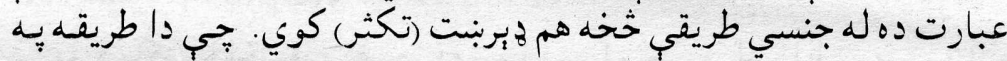
Euobacteries

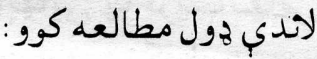

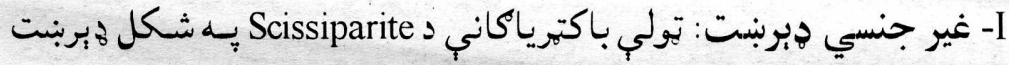

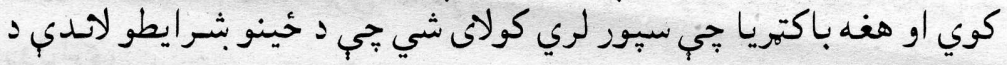
Sporolation

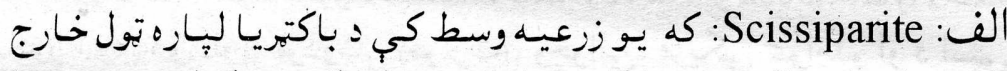

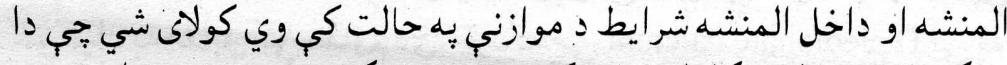

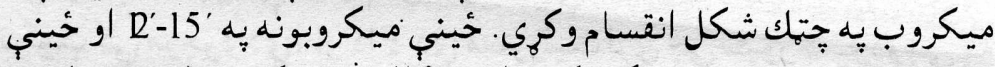

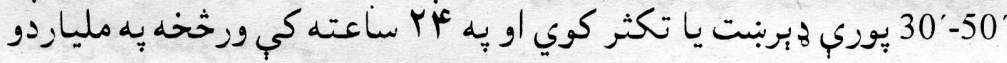

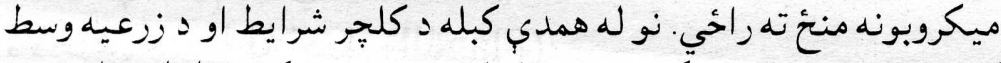

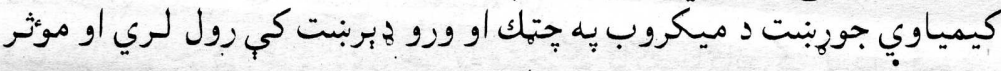




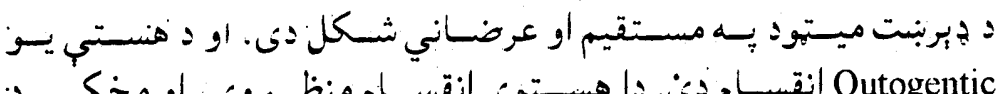
Outogentic سايتوبلازم له انقسام خخهه بيـل كبرِي.

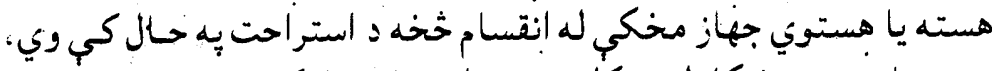

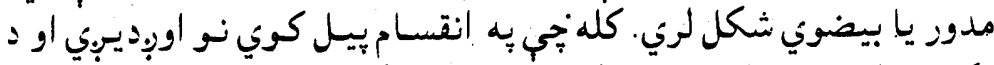

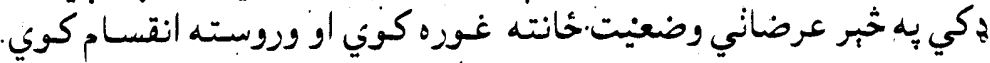

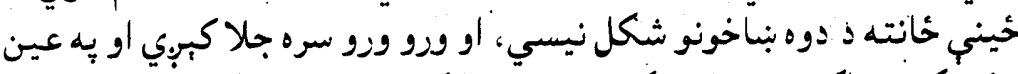

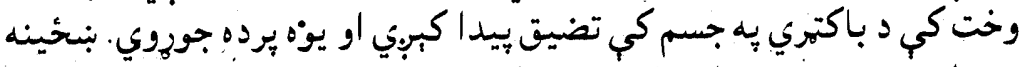

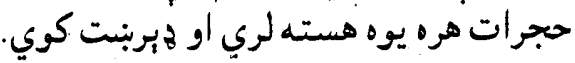

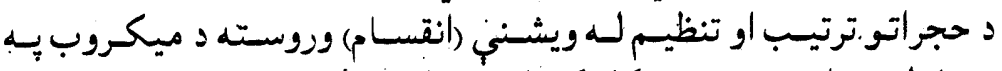

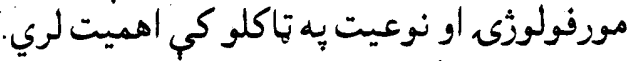
Pervot

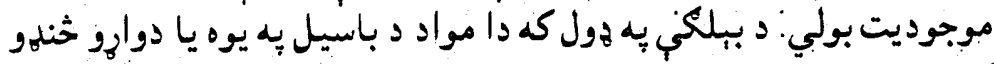

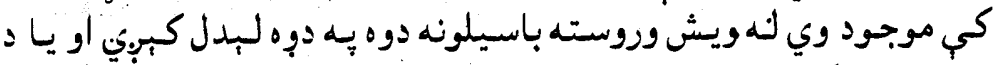

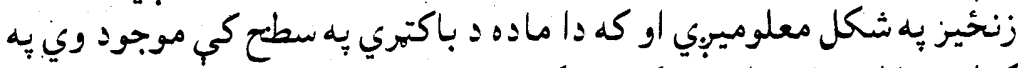

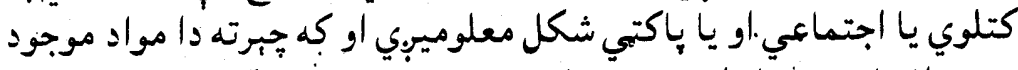

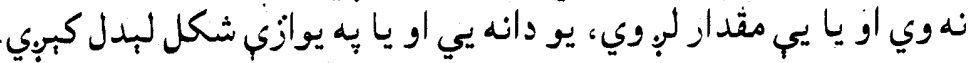

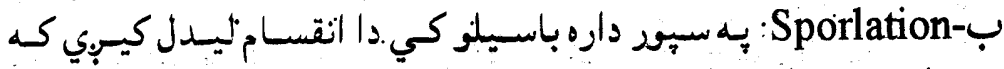

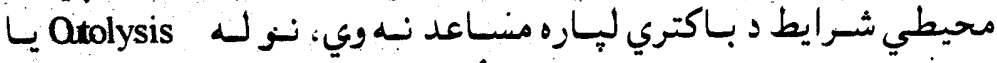

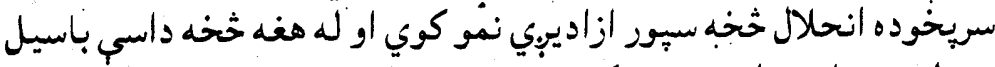

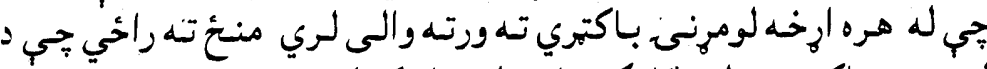

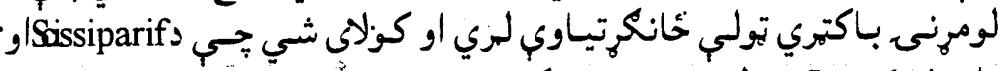

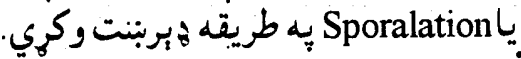

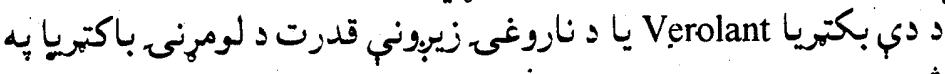
خير وي. Sporolation

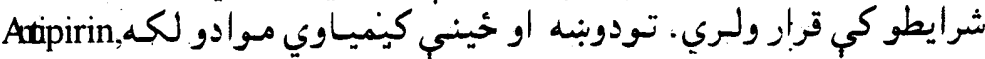
او Boric acid

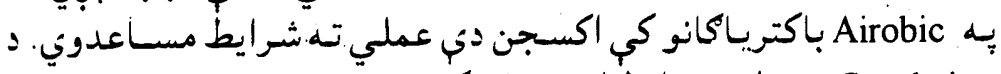

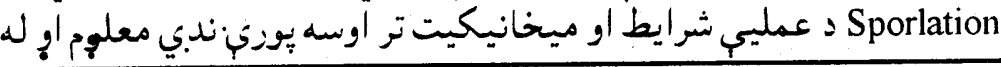




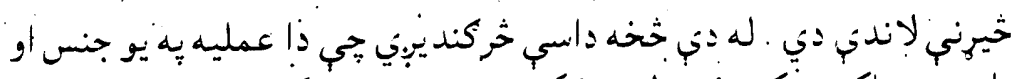

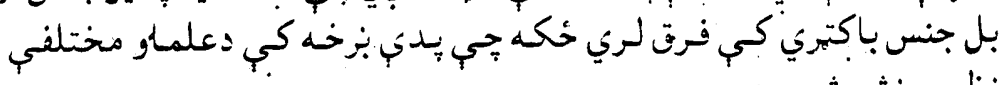

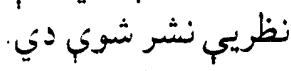

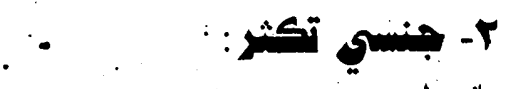

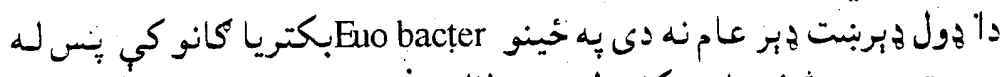

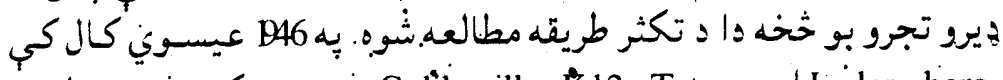

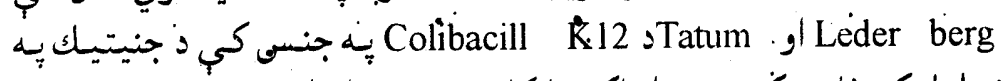

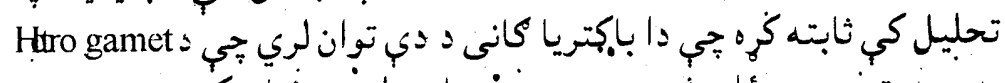

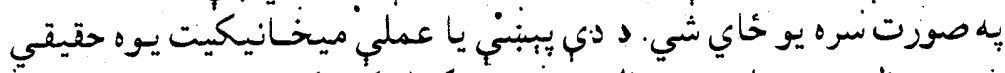

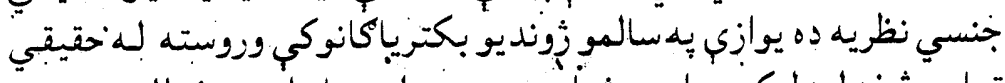

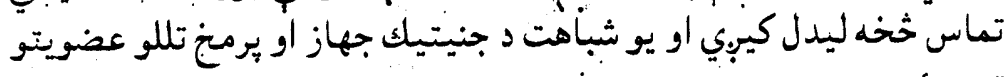

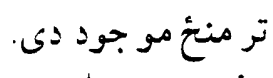

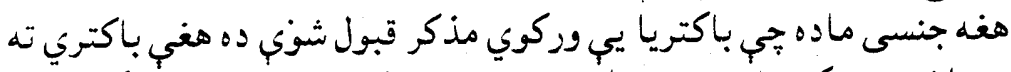

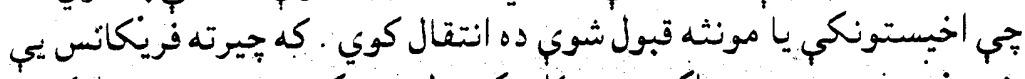

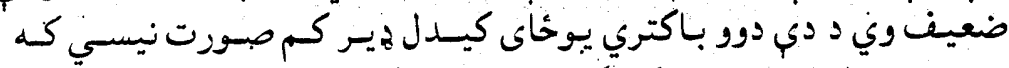

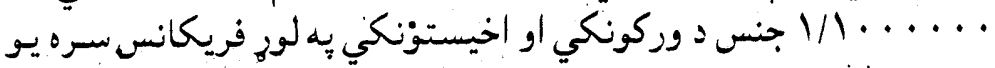

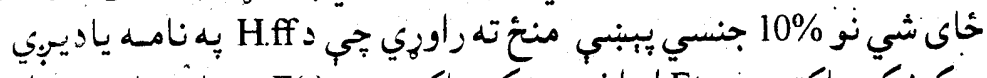

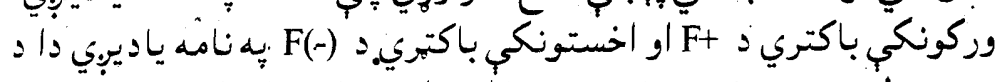

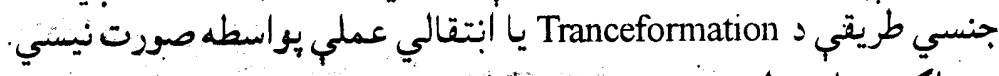

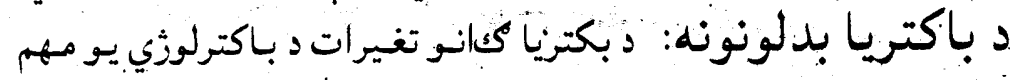

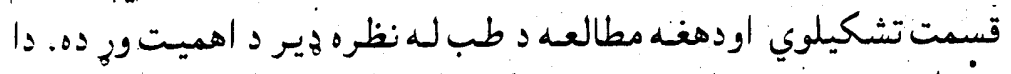

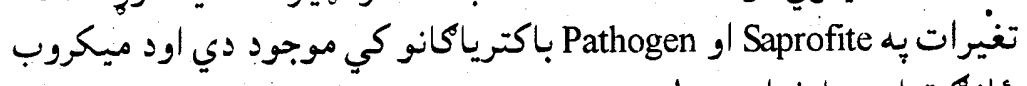

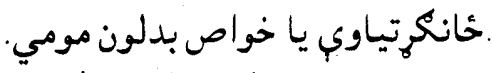

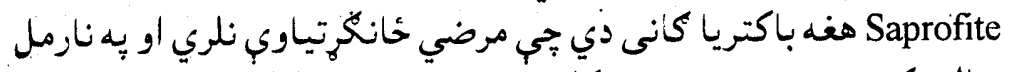

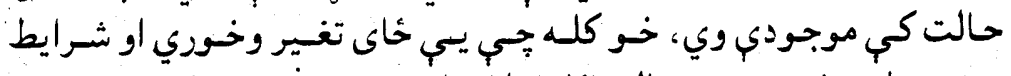

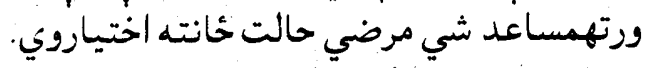

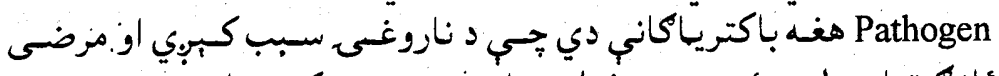

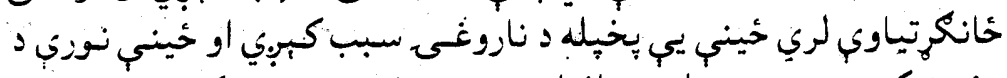

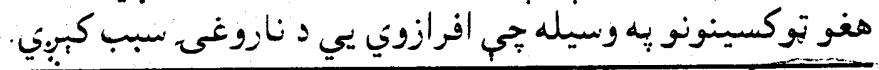




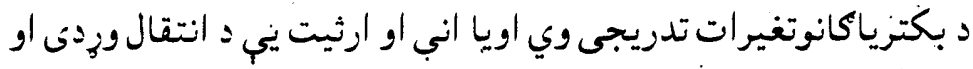

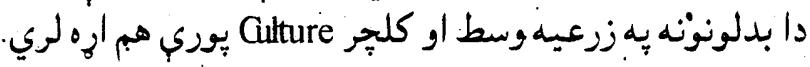

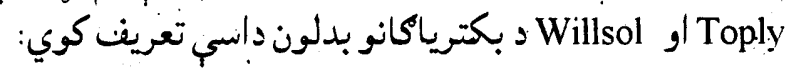

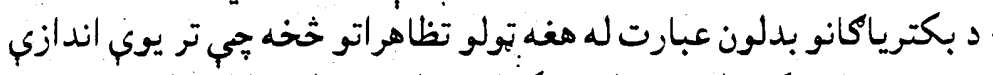

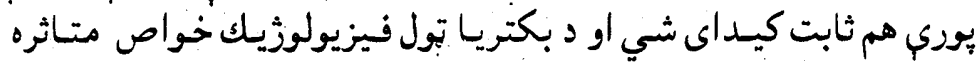

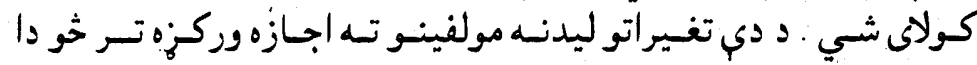

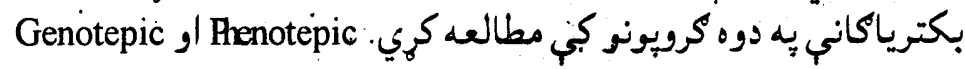

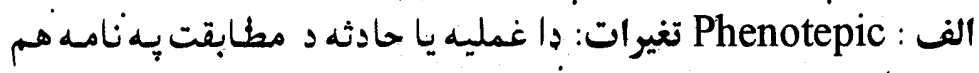

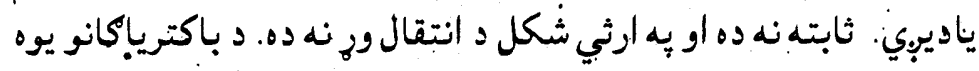

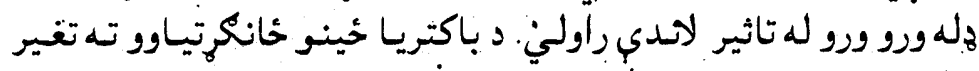

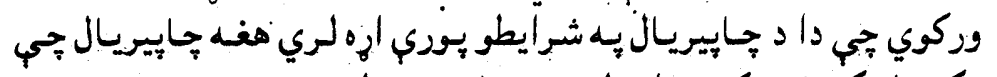

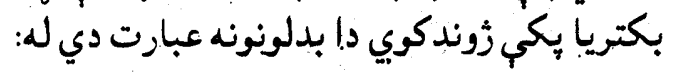

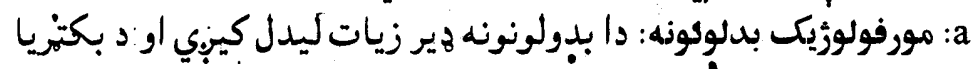

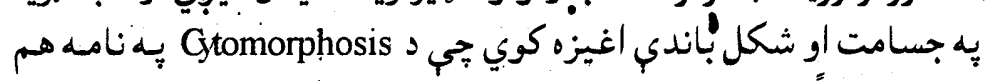

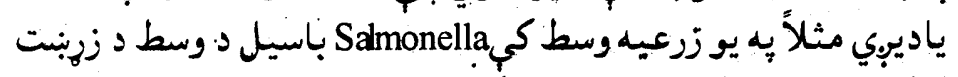

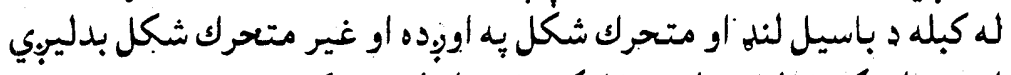

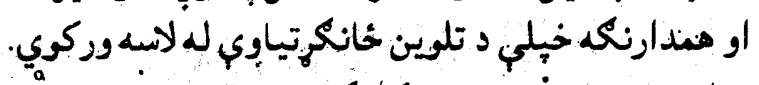

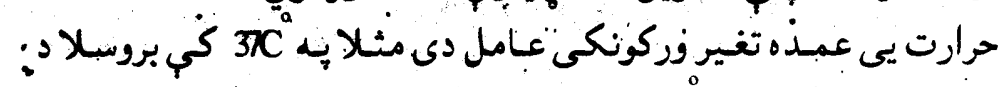

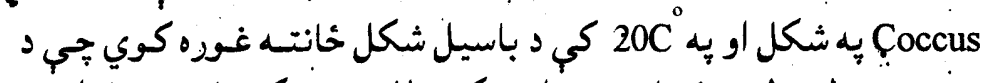

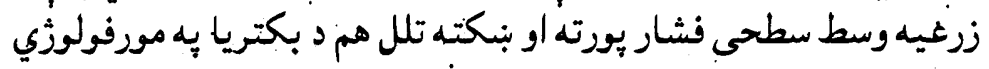

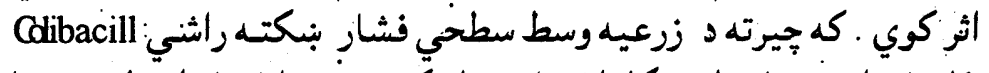

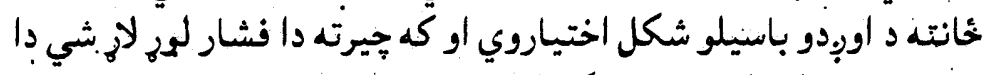

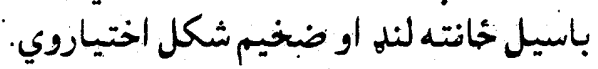

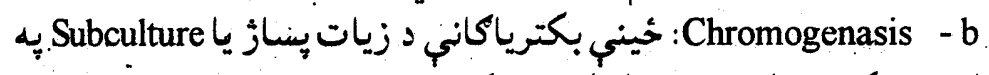

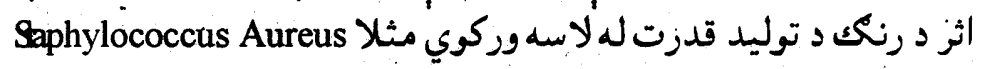

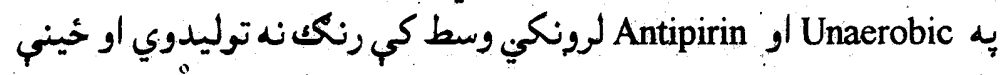

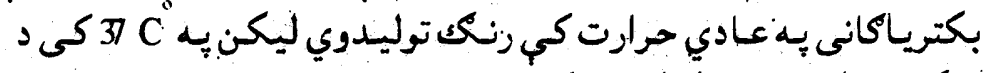

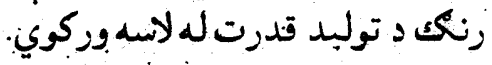

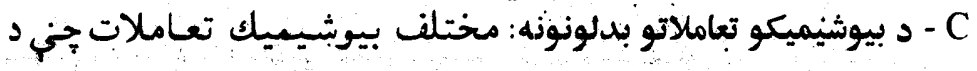





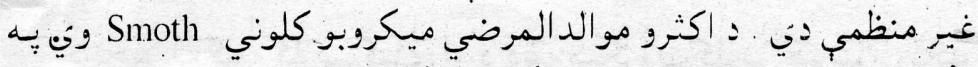

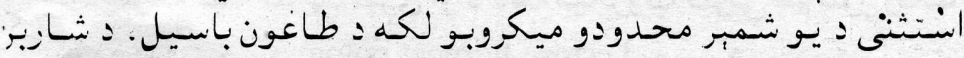

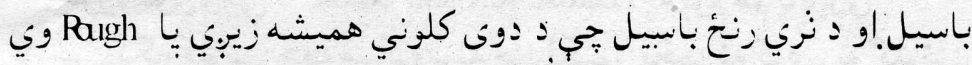

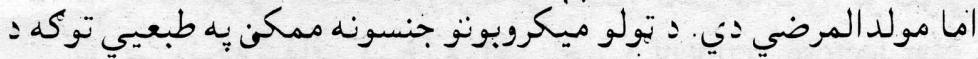

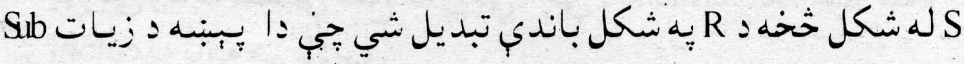

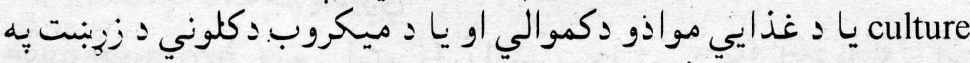

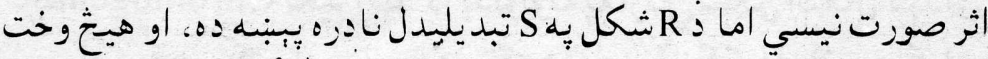

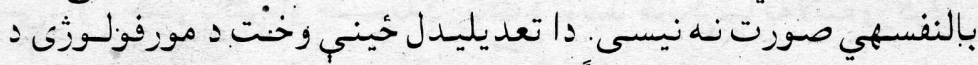

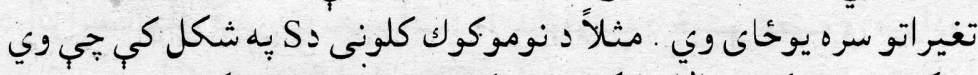

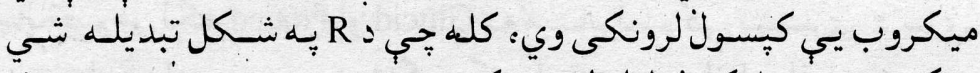

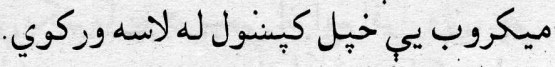

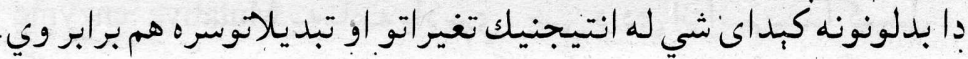

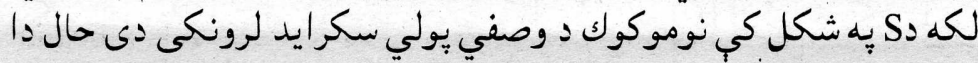

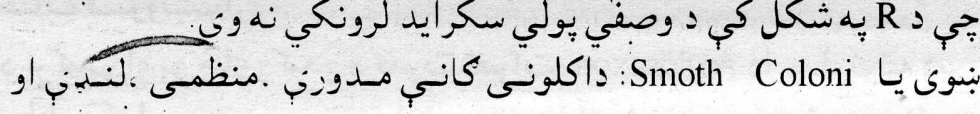
برجسته وي

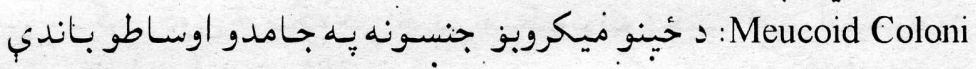

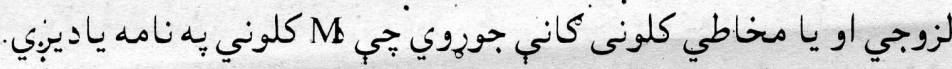

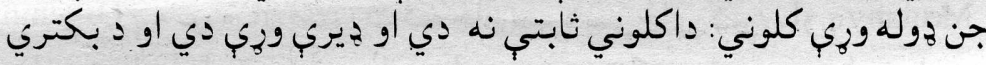

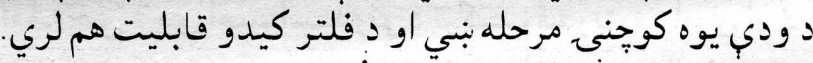

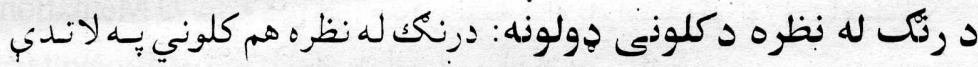

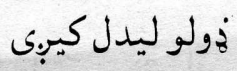

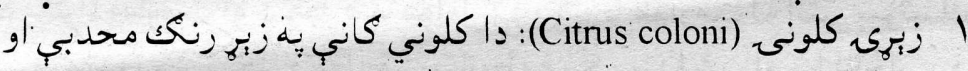
منظمي وي.

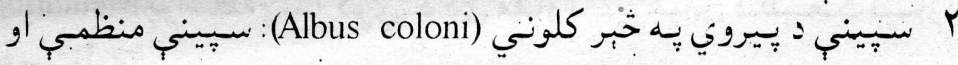

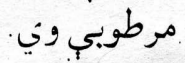

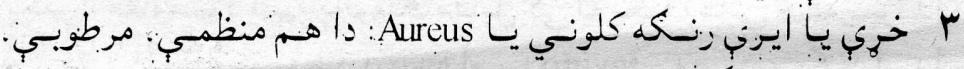

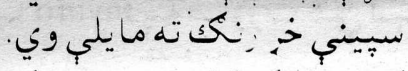

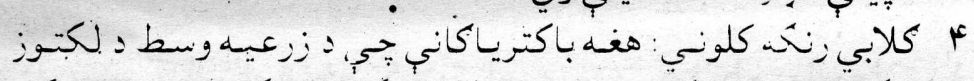

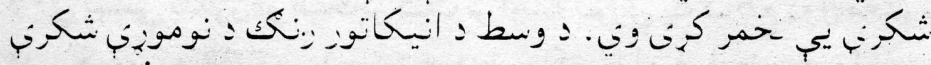


د تخمر له كبله كلابب كببري او د دغنه ميكروب كلوني هم سوزر زنكك

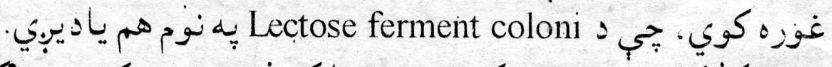

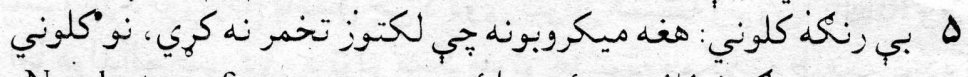

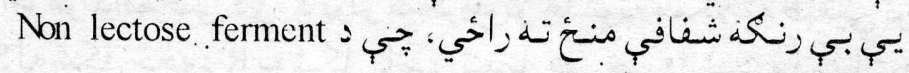
coloni

Chromogenase

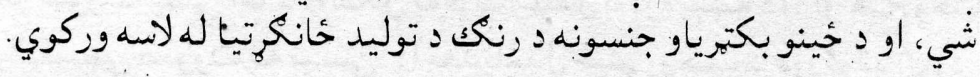

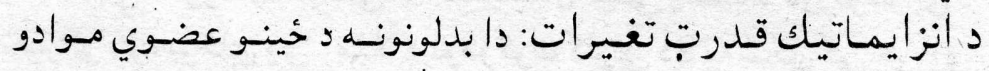

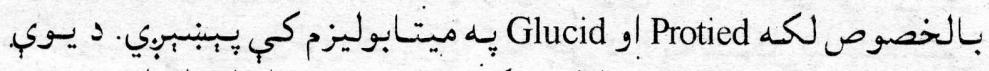

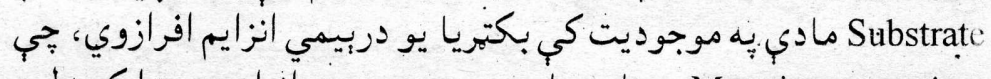

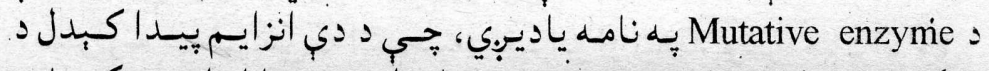

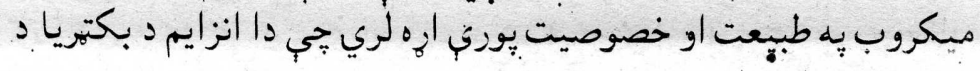
حيات مسووليت لري.

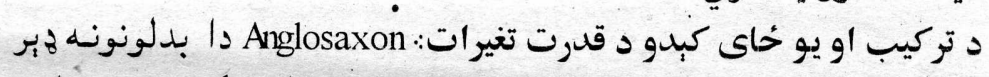

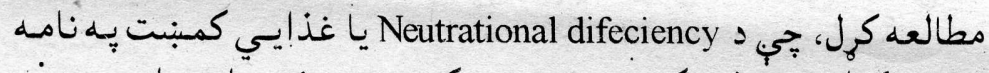

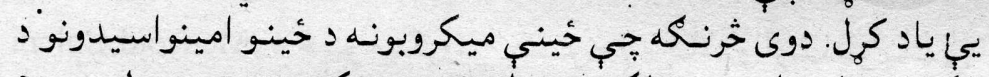

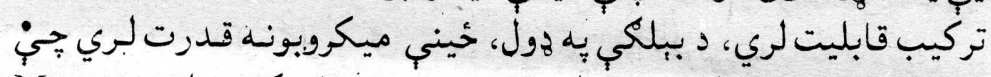

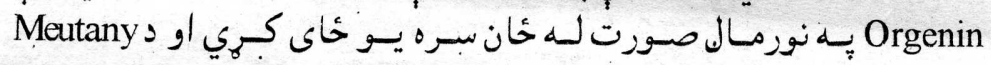

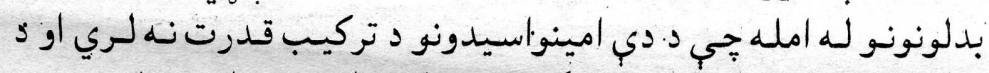

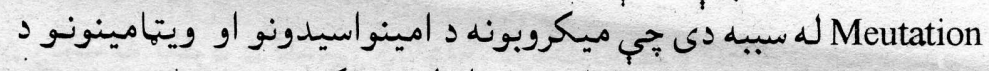

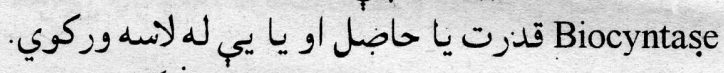

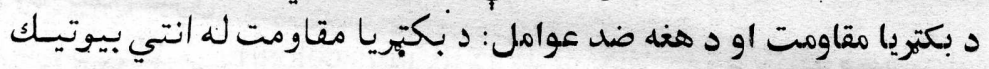

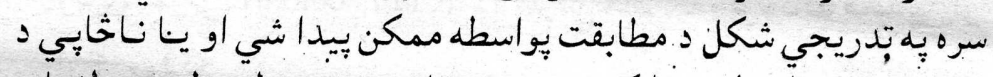

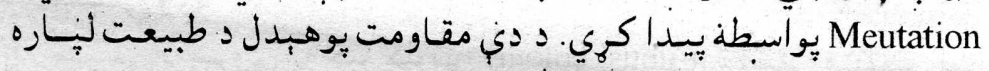

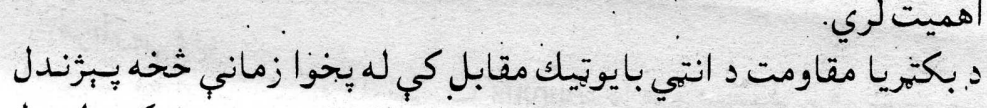

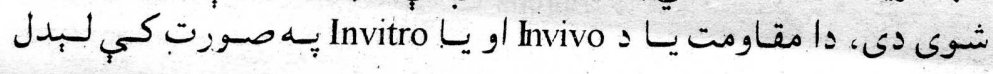
كَبرِي.

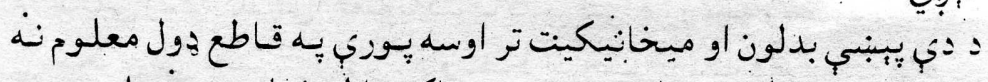

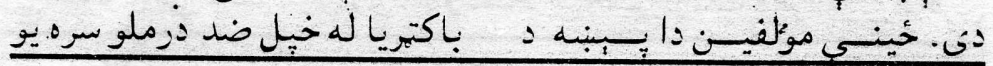


تطابقي فعل كني، او خيني يبي يو حقيقي Meutation بولي، خيني مولفين

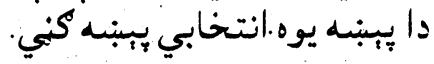

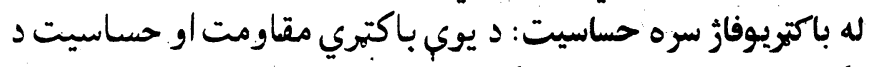

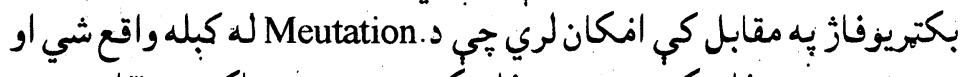

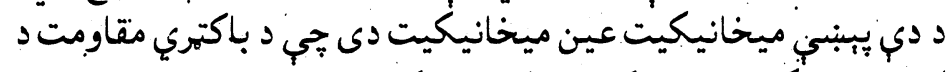

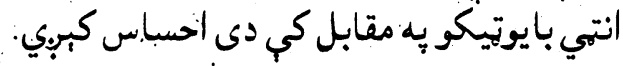

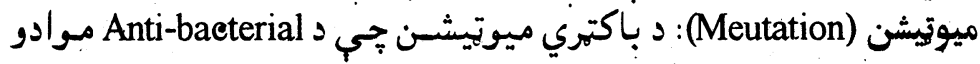

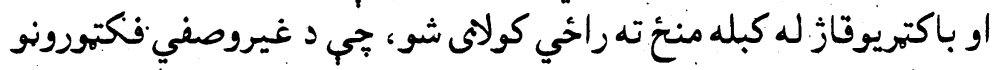

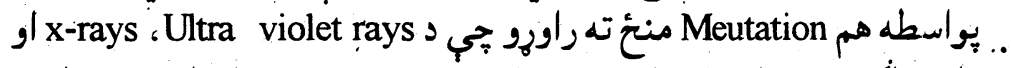

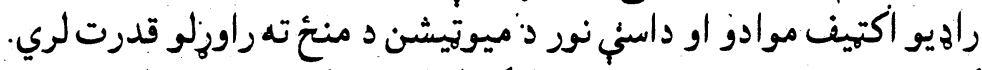

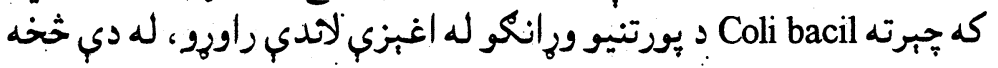

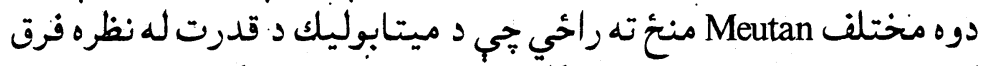

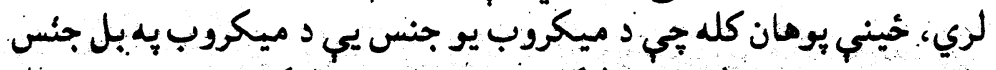

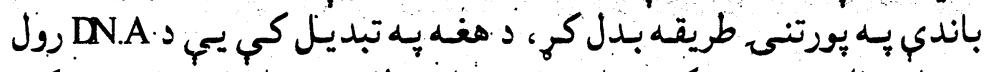

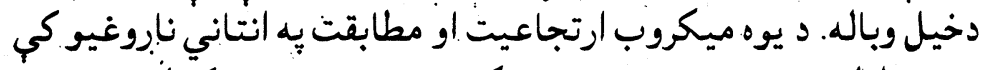

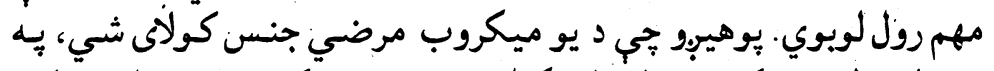

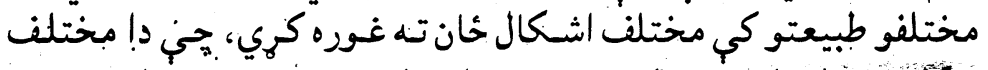

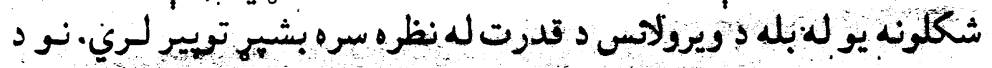

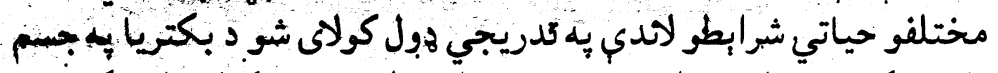

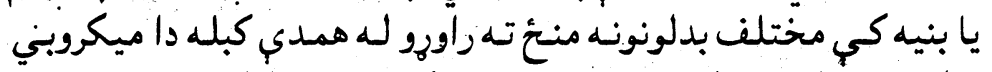

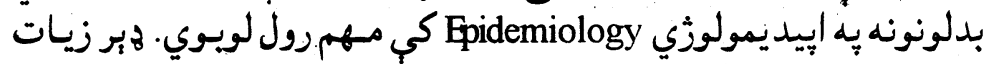

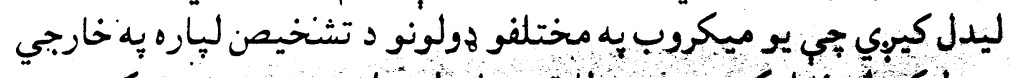

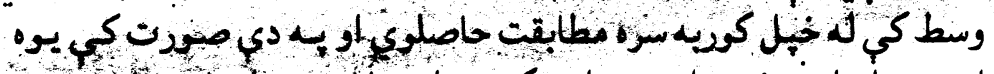

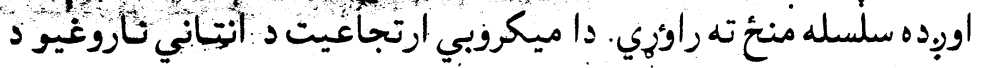

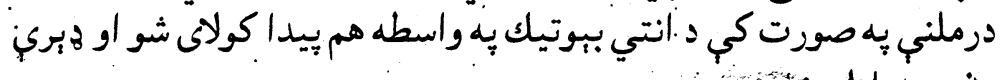

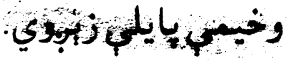

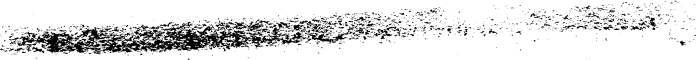




\section{د بكترياكنانو فزيالوزي}

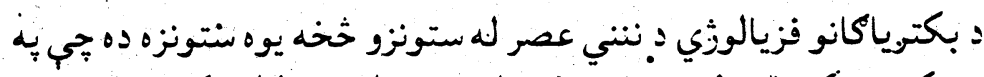

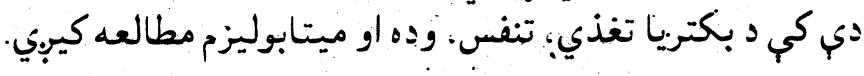
د بكتريا تغذي: ل

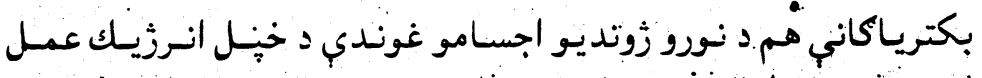

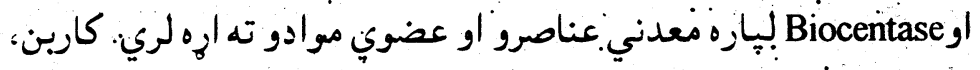

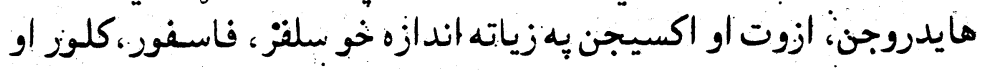

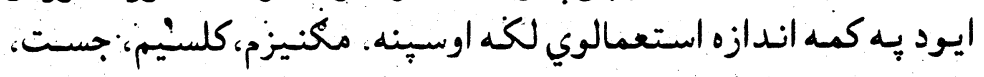

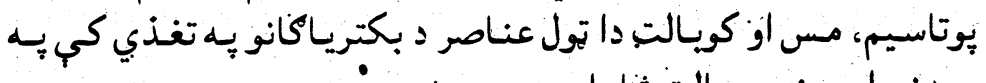

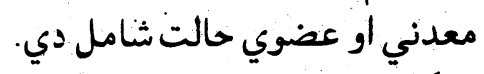

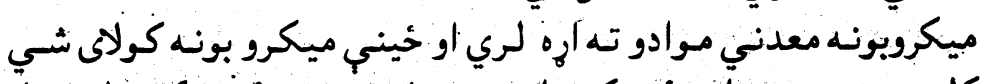

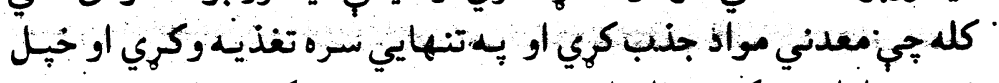

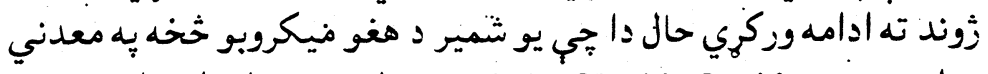

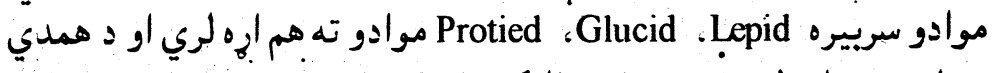

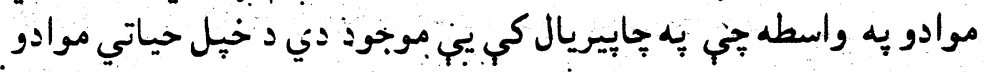

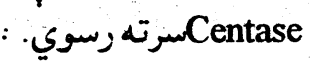

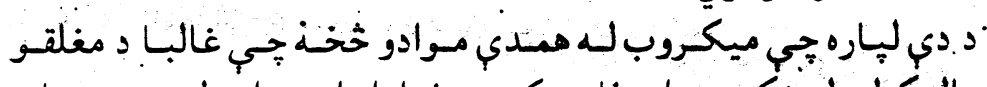

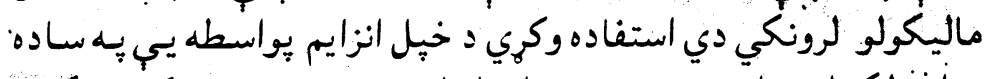

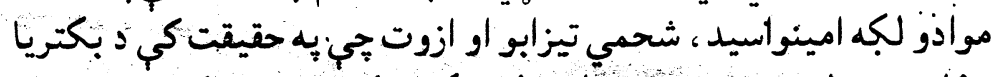

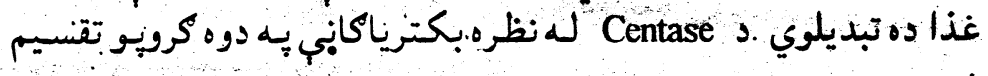

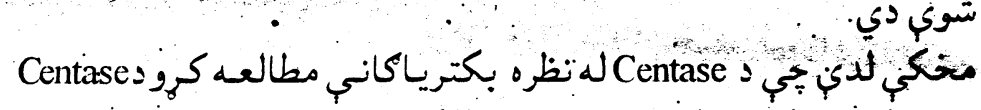

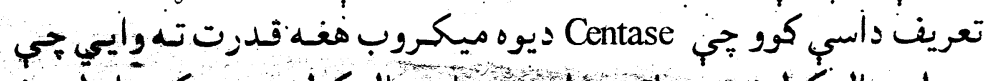

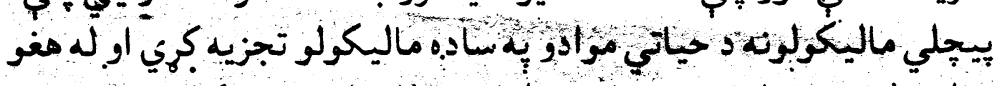

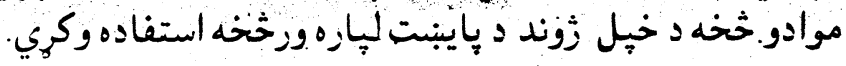
| lautotrphe: Hetrotrophe Bacteria: $r$

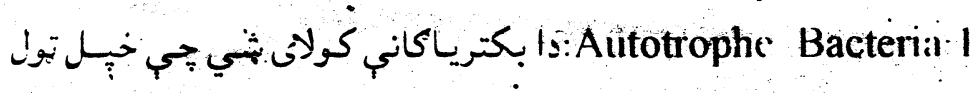




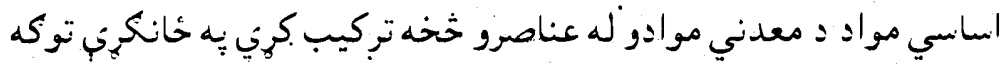

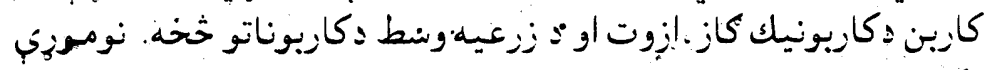

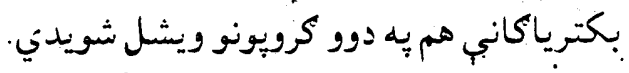

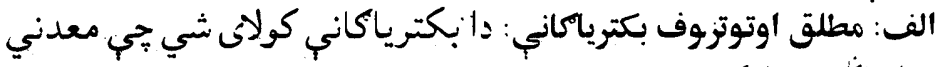

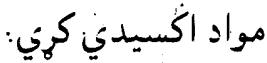

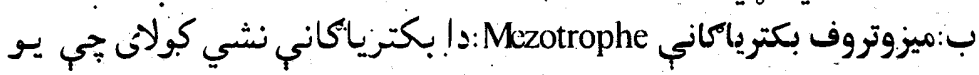

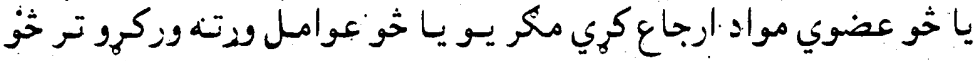

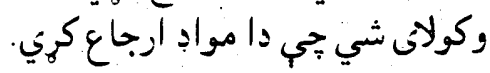

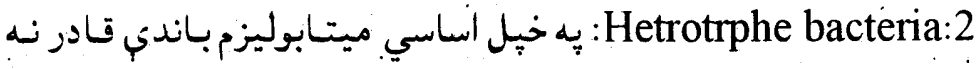

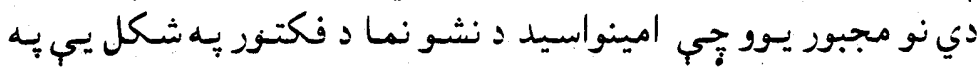

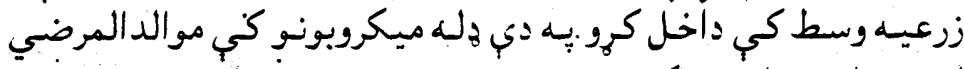

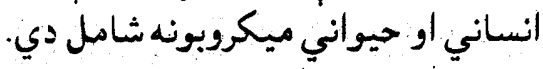

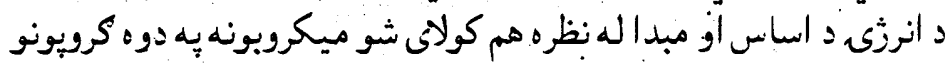

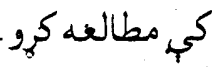

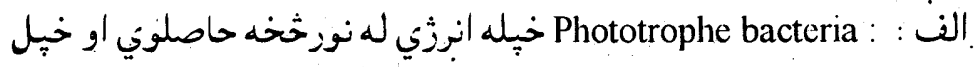

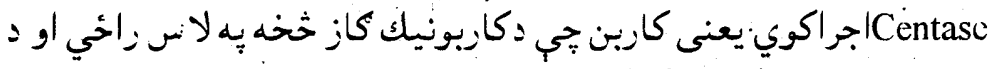

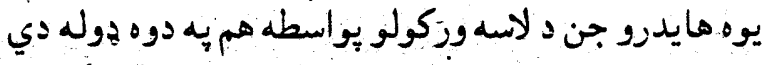

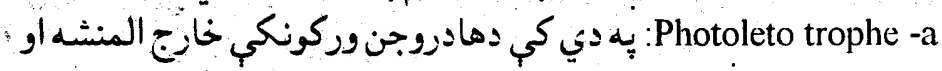
غير عضوي :ه

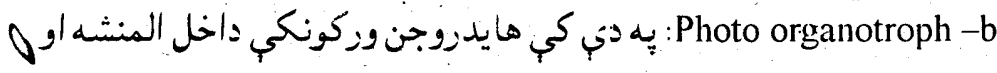
عضوي :ئي

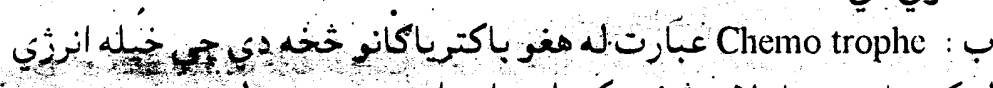

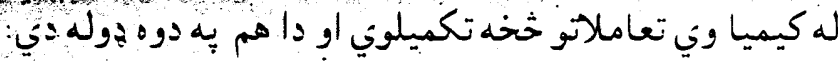

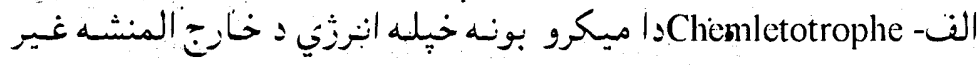

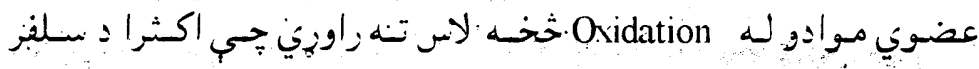

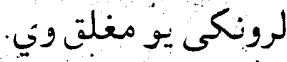

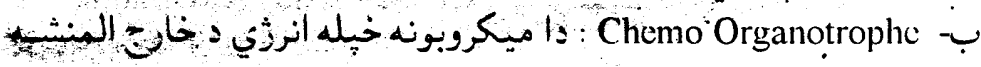

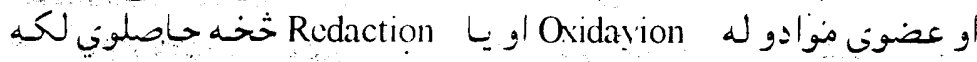

لكتيك او امينواسيديدونه له 


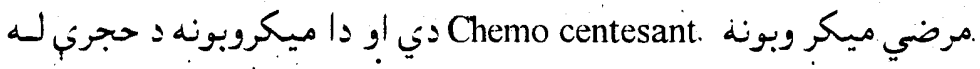

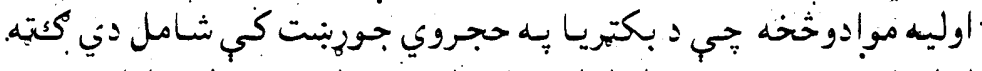

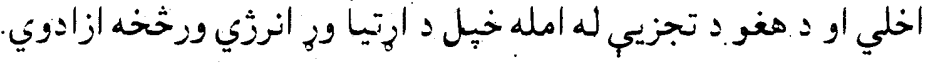

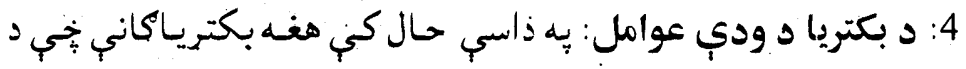

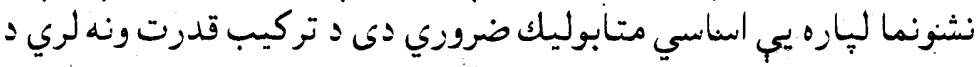

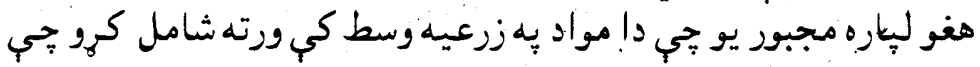

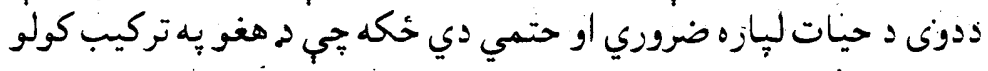
قانور نه دي.

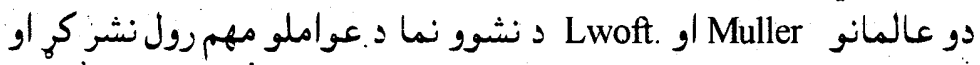

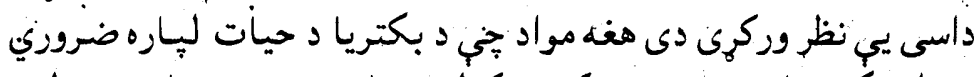

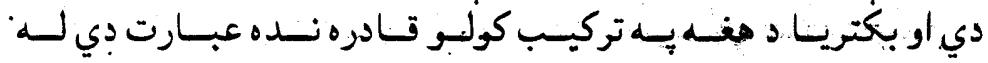

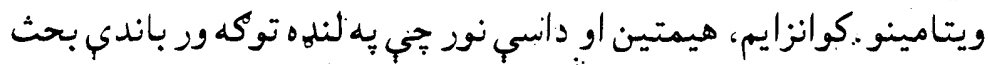

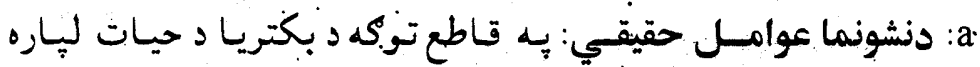

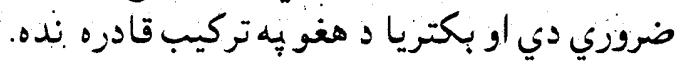

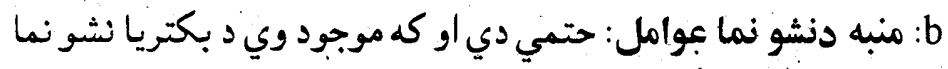
ته سرعت وركوي.

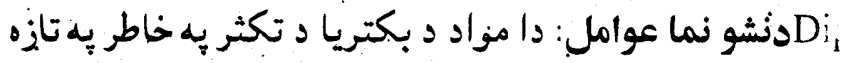

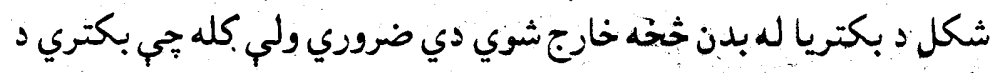

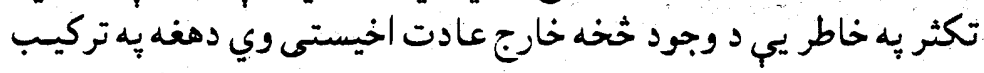

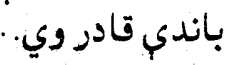

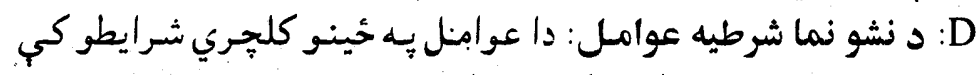

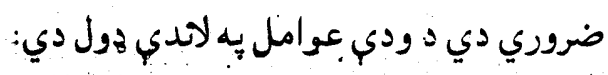

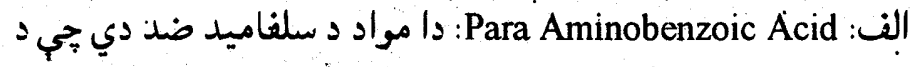
يفتري د باسيل او كلوسترديوم Clostredium د نشوونما عامل دي.

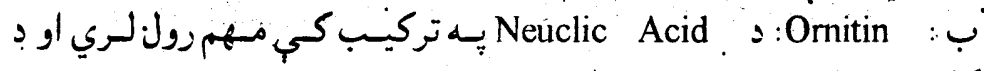

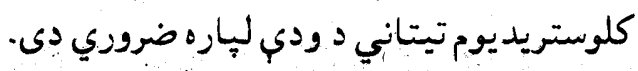

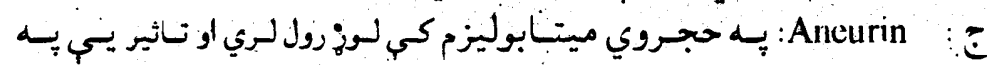

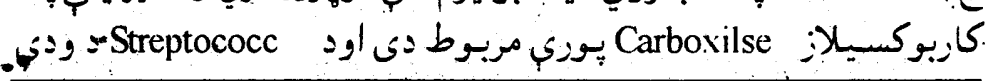




\section{ليازه مهم كنبل كيبِي.}

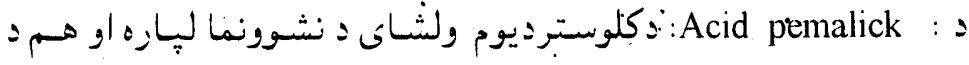

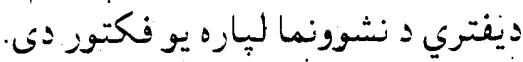

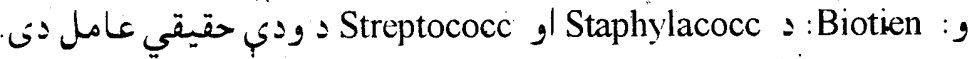

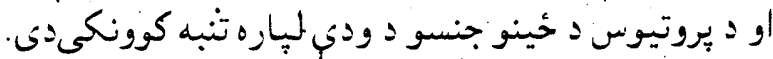

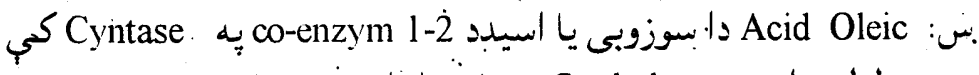
• مهم رول لري اود Staphylacocc د وني عامل دئ.

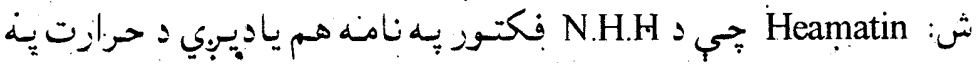

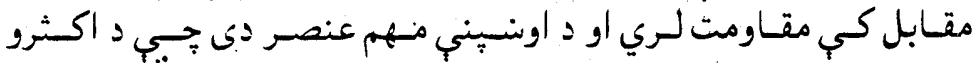

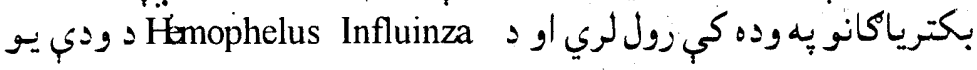
حقيقي عامل دى.

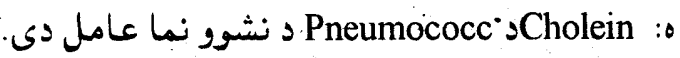

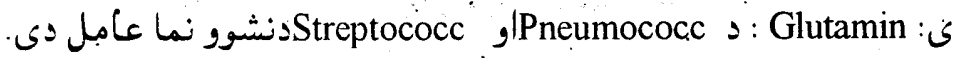

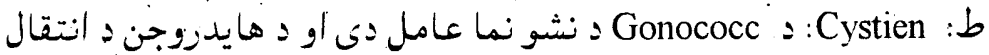

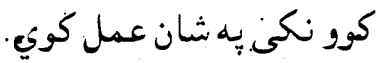
ظ: Streptococc Hemolytic Staphylococc

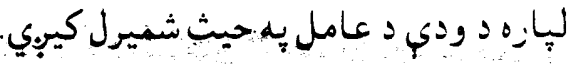

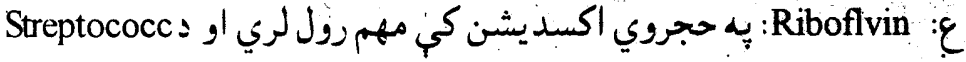

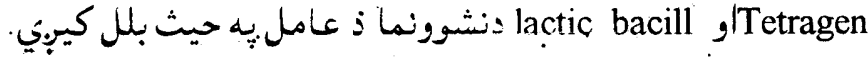
غ: Coli bacill : :Vitamin B12 ودي عامل :ث. 


\section{تعقيم يا Strielization}

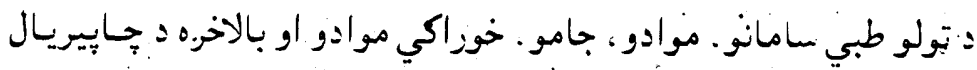

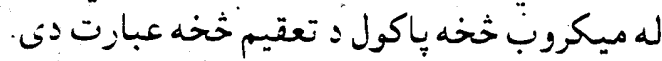

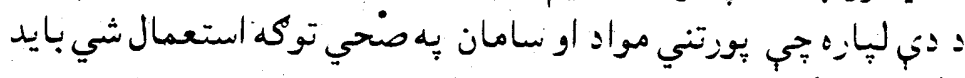

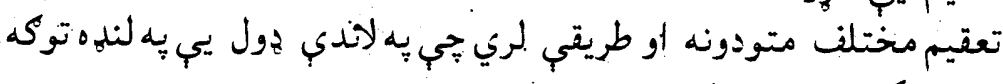

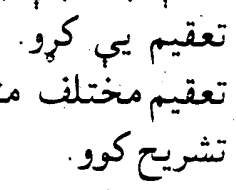

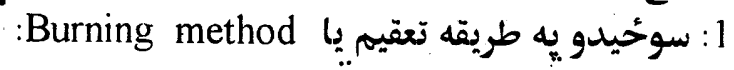

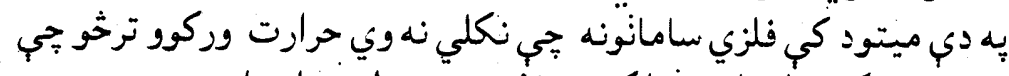

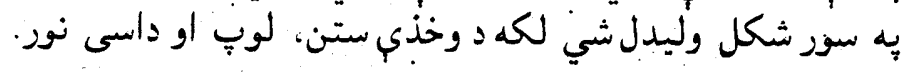

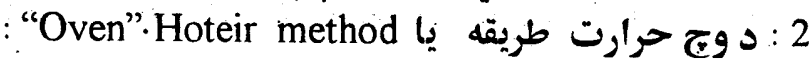

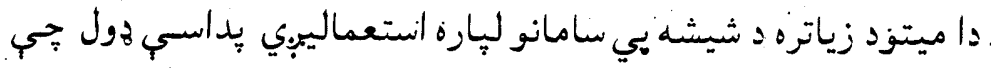

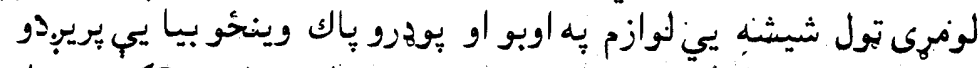

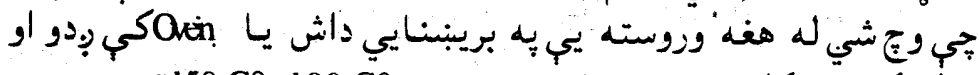

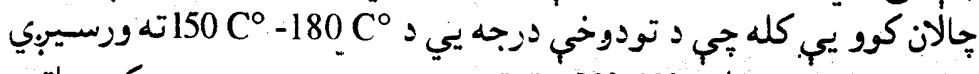

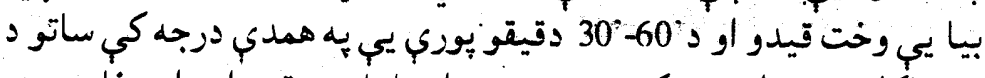

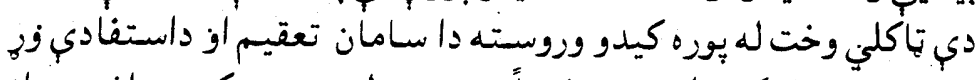

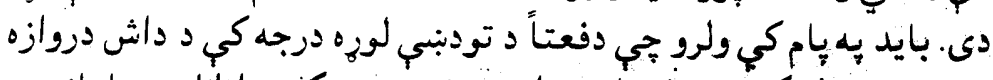

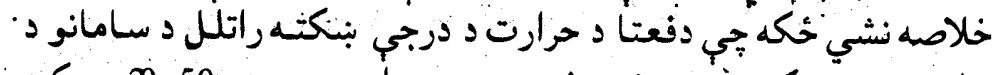

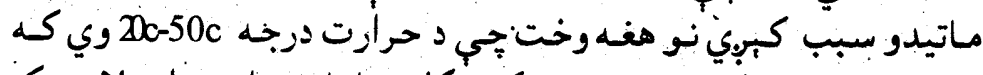

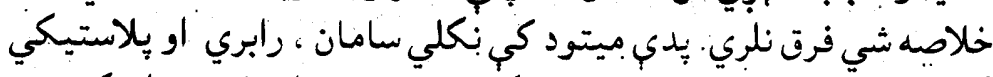

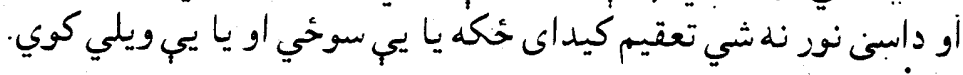

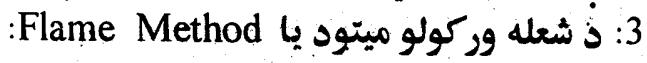

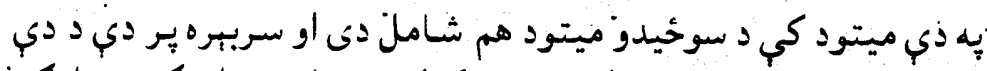

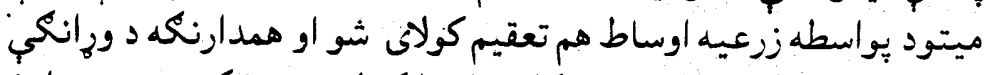

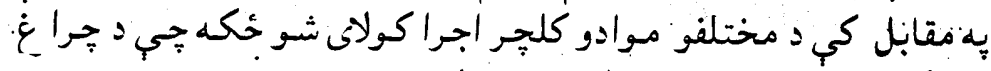
وبرانكه

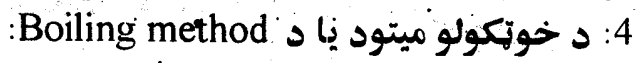

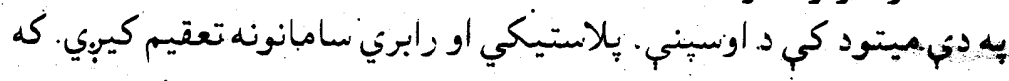




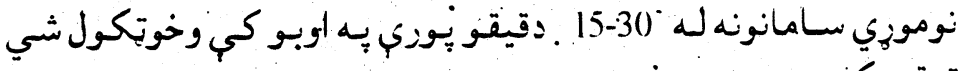
تعقيم كينبي.

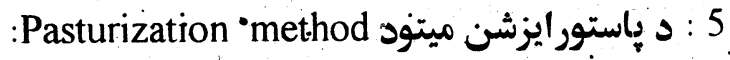

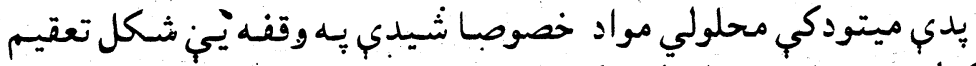

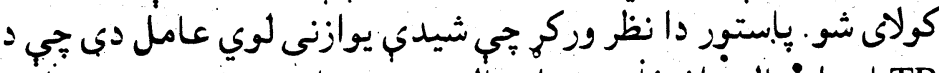

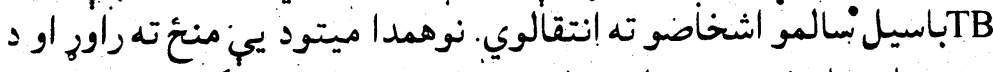

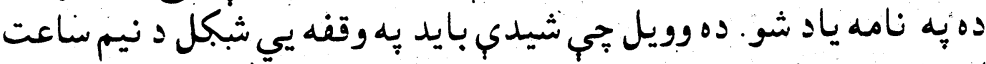

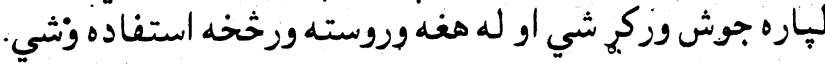

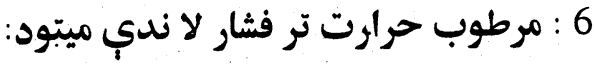

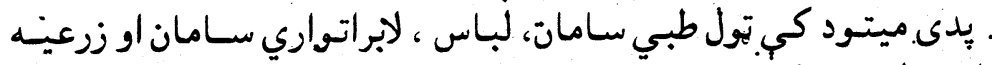

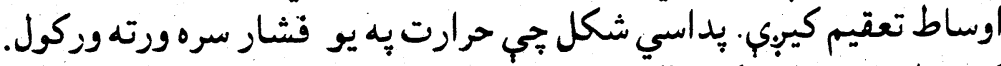

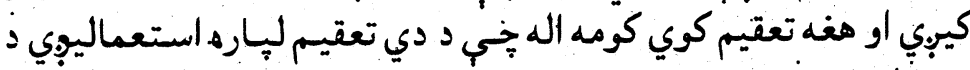
فانزي

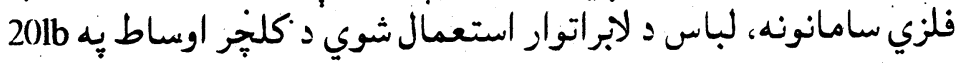

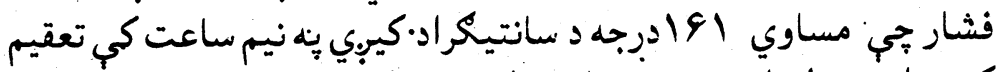

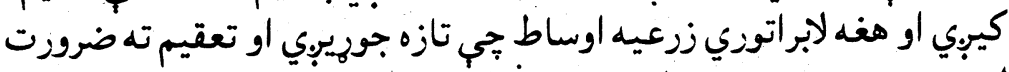

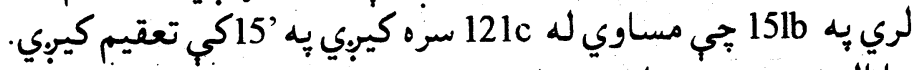

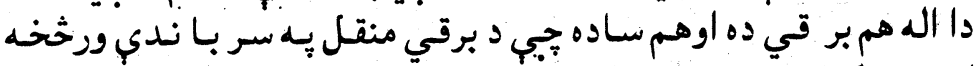

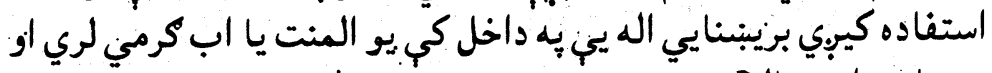

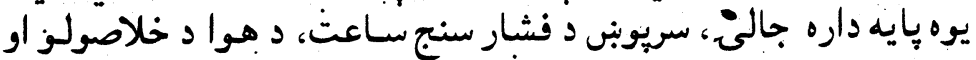

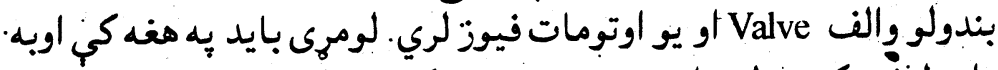

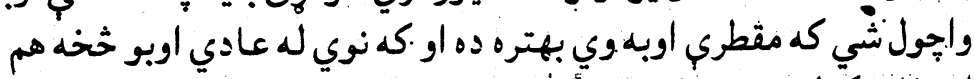

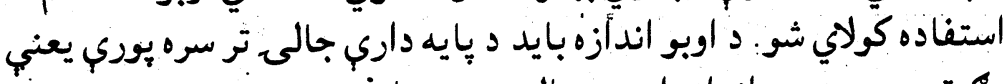

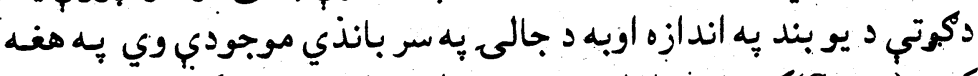

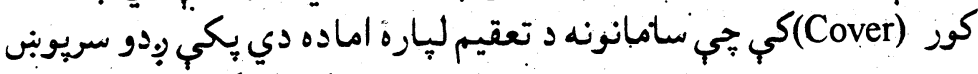

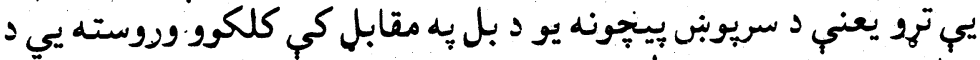

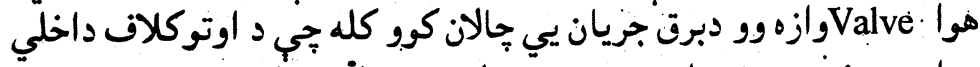

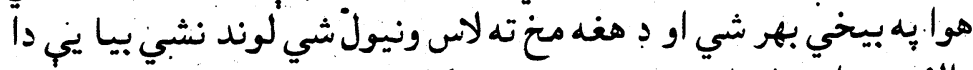

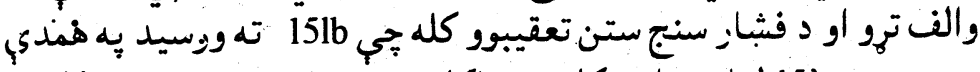

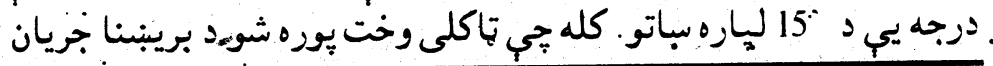




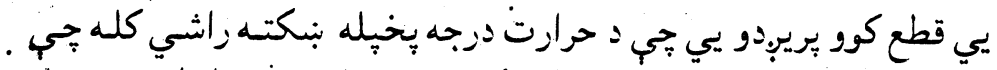

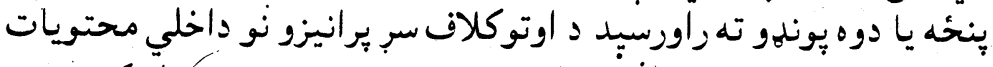

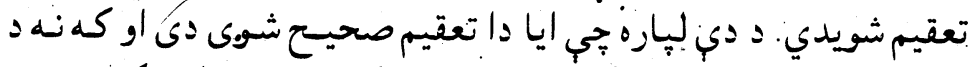

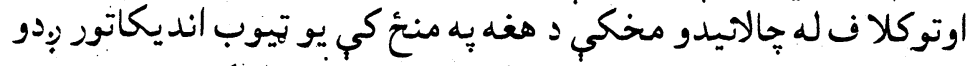

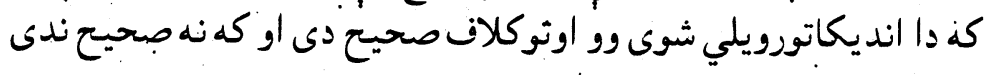
اجرا شوى.

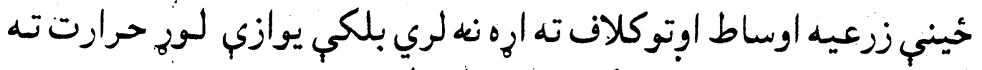

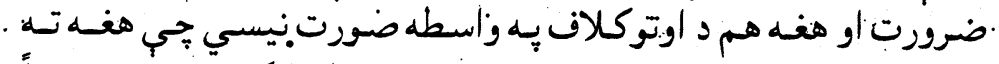
Steem .

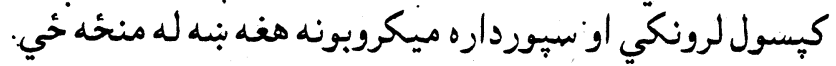
7-

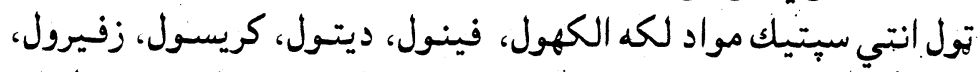

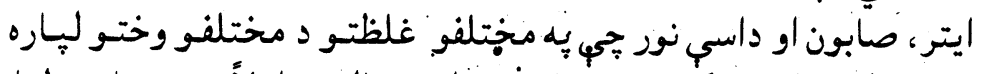

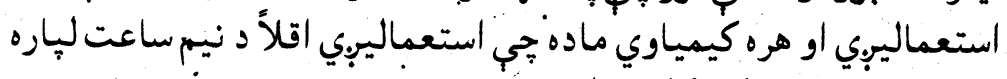

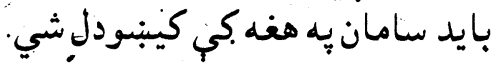
8: د فيبلتريشن ميتود Filtration method:

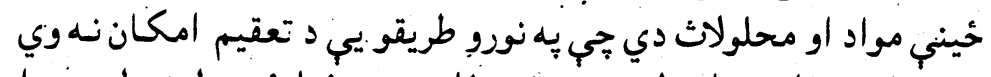

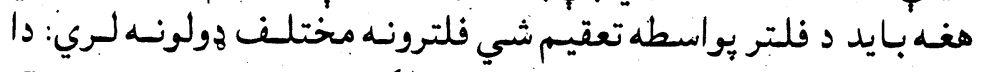

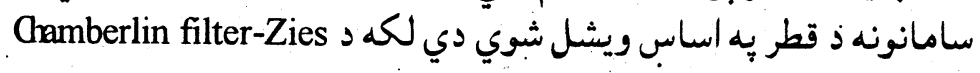
Millipoor Filter f filter

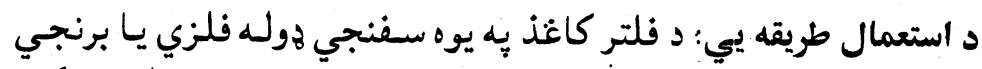

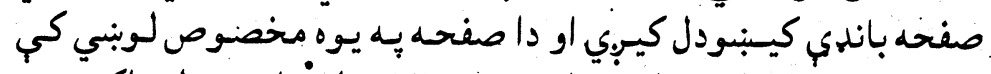

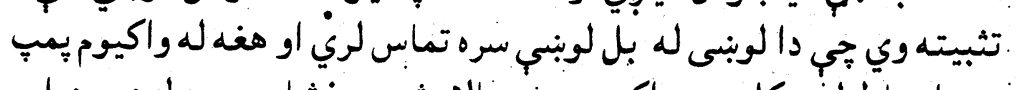

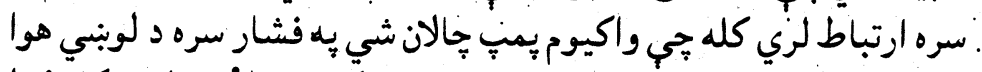

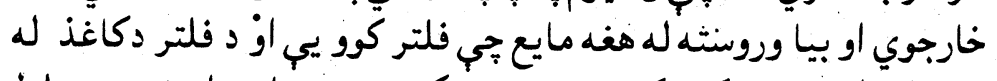

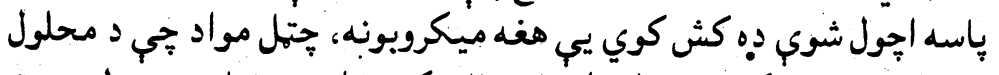

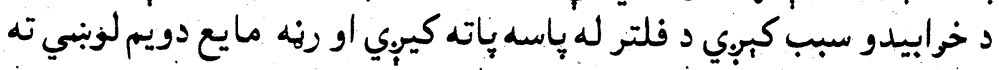

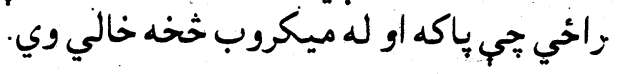




\section{CULTURE. MEDIA}

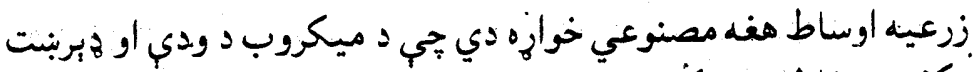

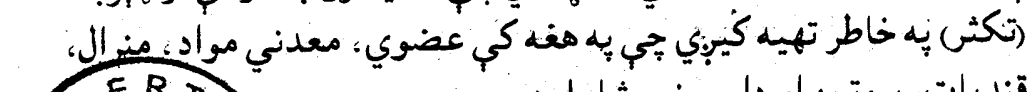

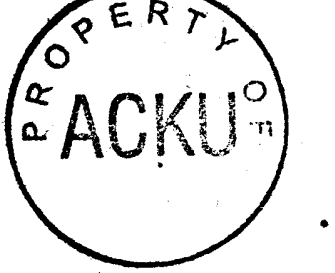

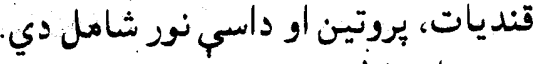

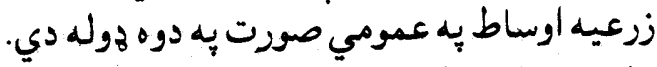
Broth media 1 Solid media جَامد اوساط اوطاط

ايع اوساط Broth media:

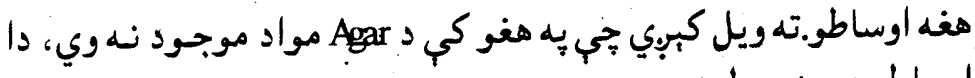

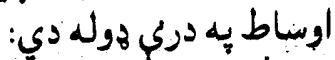

Simple broth media الف: ساده مايع اوساط

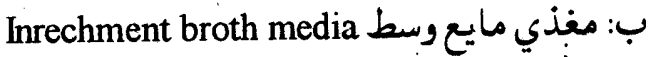

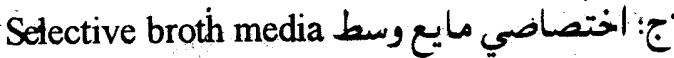

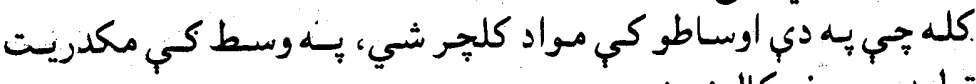

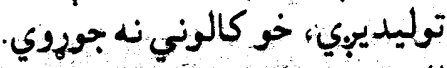

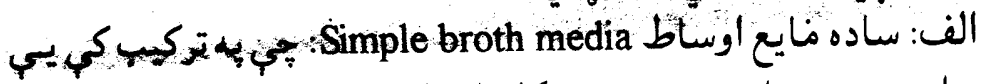

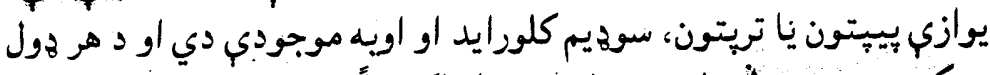

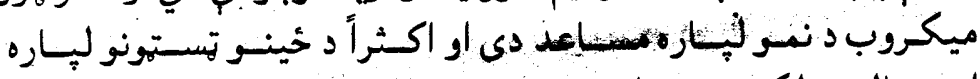
استعماليبوي لكه يَتون واتير ملهيا.

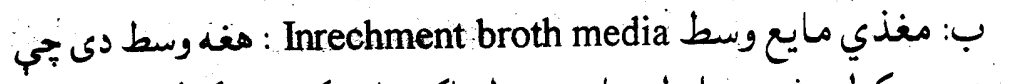

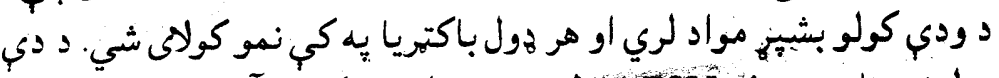

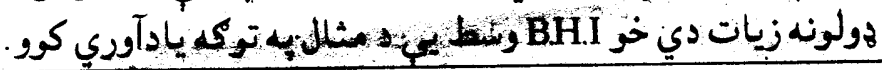

\begin{tabular}{|c|c|}
\hline \multicolumn{2}{|c|}{ Brain Heart Infusion Broth (B. H. ) } \\
\hline Call Brain Infussion $200 \mathrm{gm}$ & Sodium Chloride $5 \mathrm{gm}$ \\
\hline Beef Heart Infusion $250 \mathrm{gm}$ & Di Sodium Phosphate $2.5 \mathrm{gm}$ \\
\hline Proteus Pepton Defco & Distelled water $1000 \mathrm{cc}$ \\
\hline Becto Dextrose & \\
\hline & \\
\hline
\end{tabular}




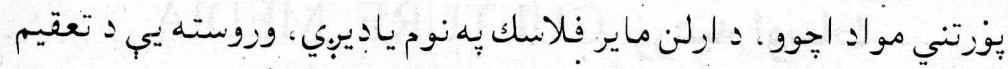

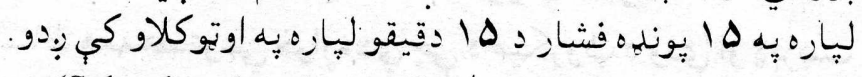

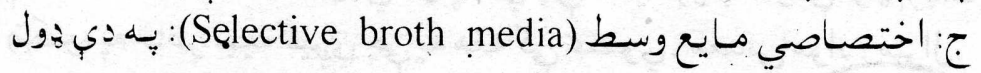

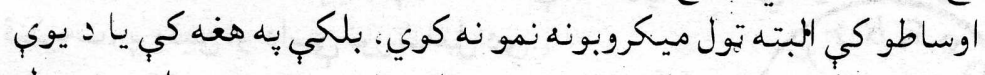

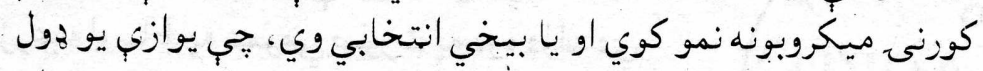

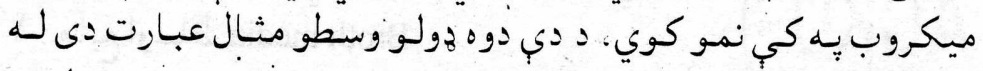

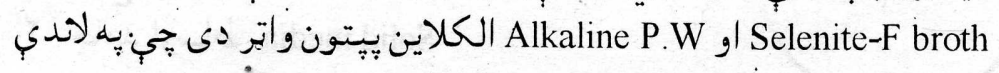

Alkaline pepton Water

$\begin{array}{ll}\text { Pepton bacto } & 1 \mathrm{gm} \\ \text { Destilled water } & 100 \mathrm{cc} \\ \mathrm{Ph} & 8\end{array}$

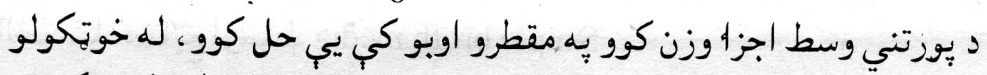

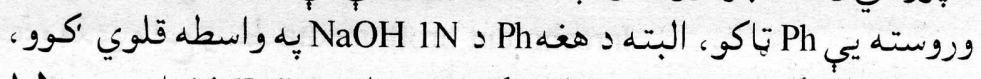

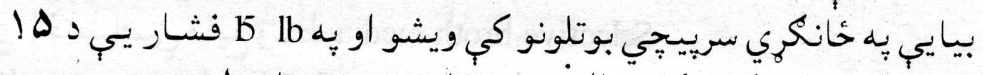

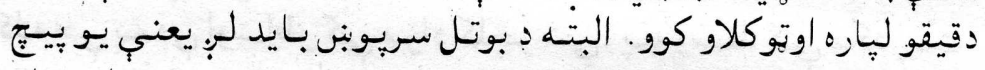

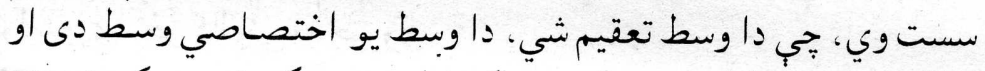

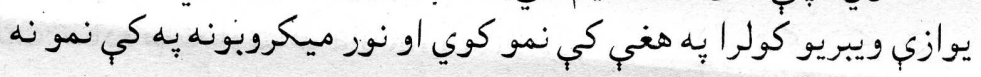

: Selent F broth

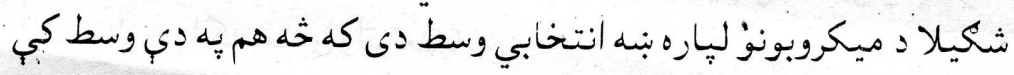
E. Coli

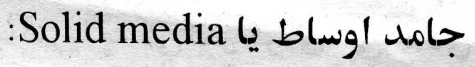

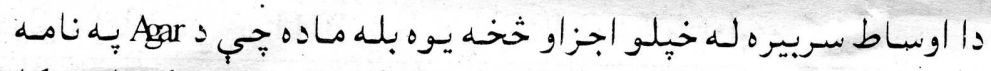

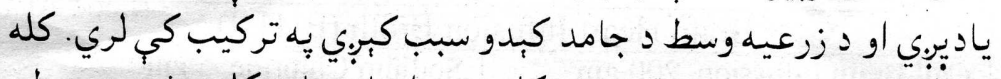

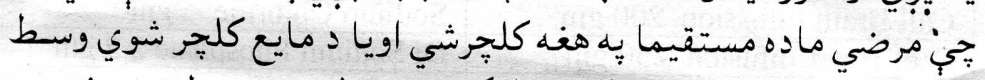

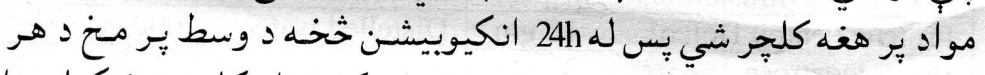

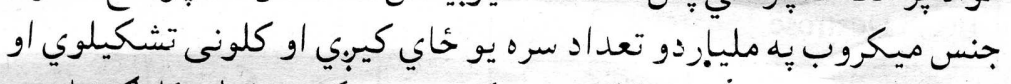

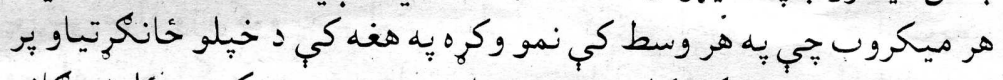

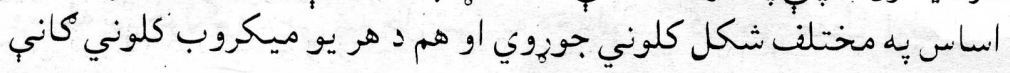




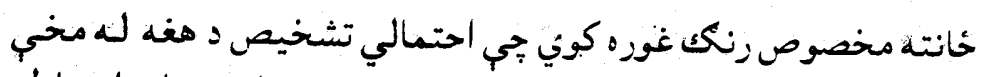

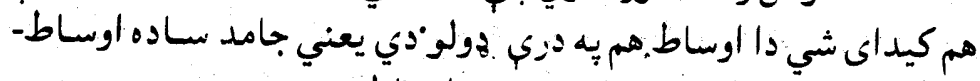

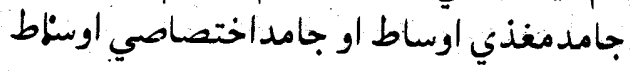

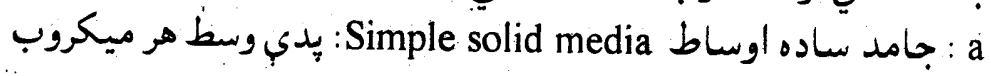

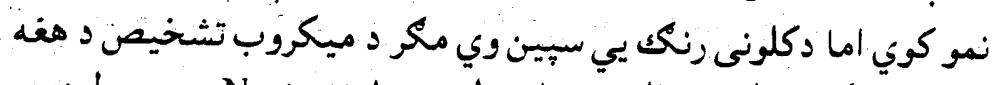

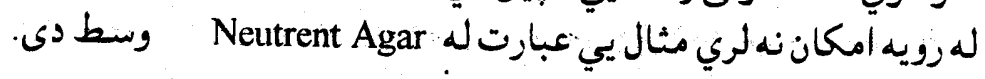

Bacto Beef Extract $=3 \mathrm{gm}$

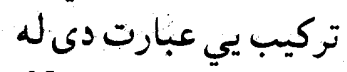

D. Water $=1000 \mathrm{cc}$

Bacto agar $=15 \mathrm{gm}$.

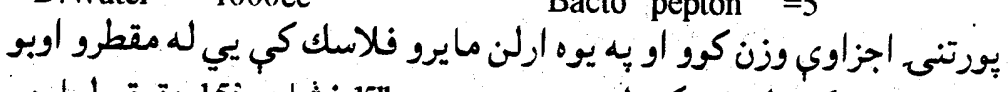

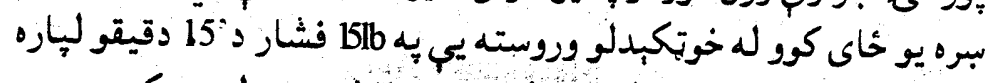

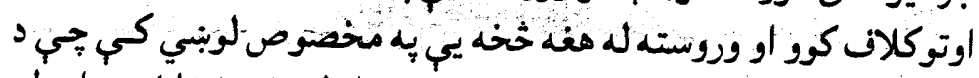
petri desh

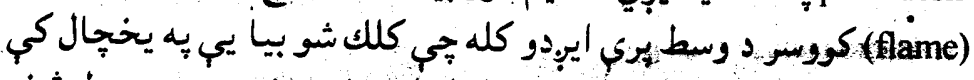

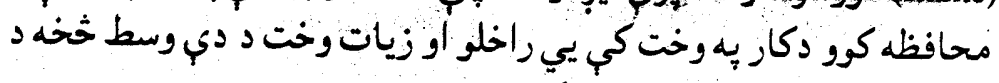
Antibiogram

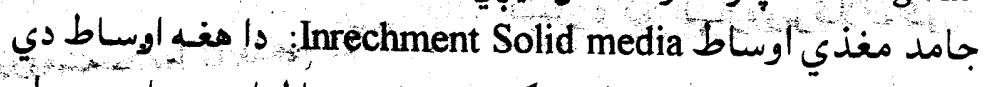

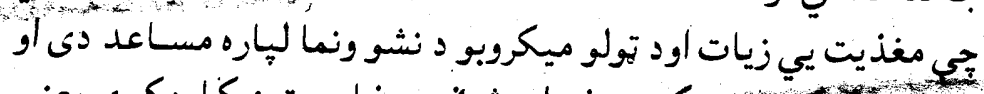

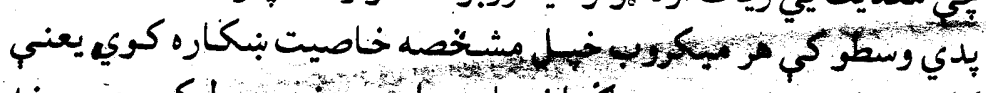

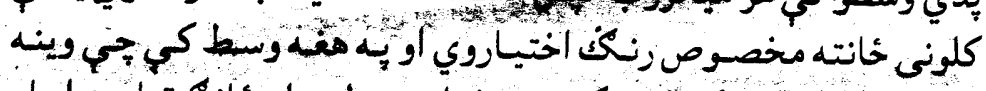

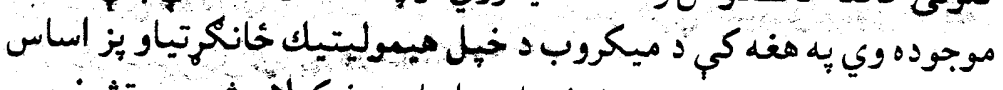

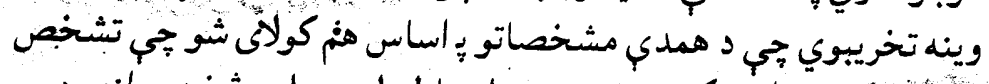

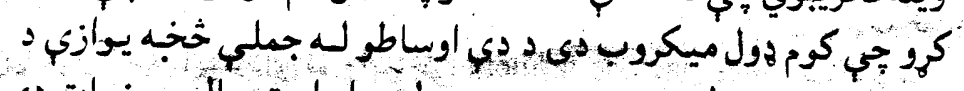
Blood Agar مثال يه توكه دلته ذزكر كوو.

Blood Agar Base

$\begin{array}{ll}\text { 1. Proteus pepton }=15 \mathrm{gm} & \text { 4. Sodium Chloride }=5 \mathrm{gm} \\ \text { 2. Liver Digst }=2,5 \mathrm{gm} & \text { 5. Bacto Agar }=12 \mathrm{gm} \\ \text { 3. Bacto Yest Extract }=5 \mathrm{gm} & \text { 6. D.W. }=1000 \mathrm{cc}\end{array}$

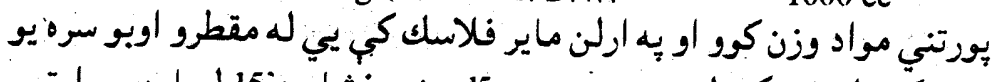

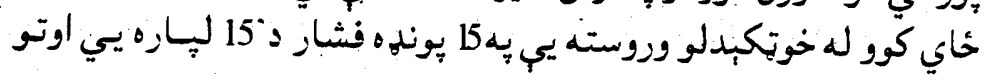




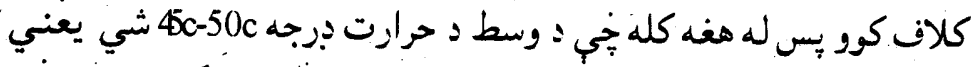

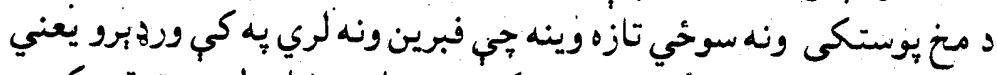

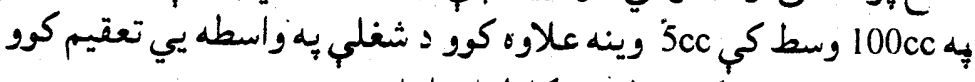

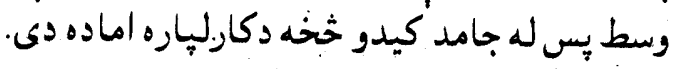
جامد مشُخصه يا انتخابي اوسأط Selective 'Solidmedia

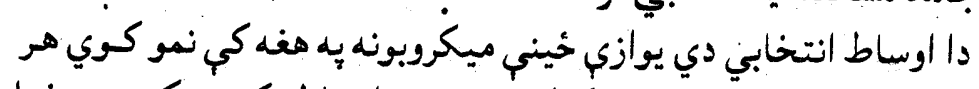

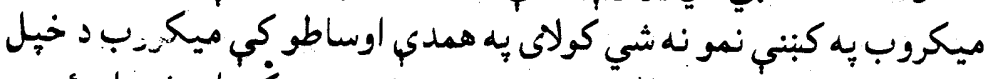

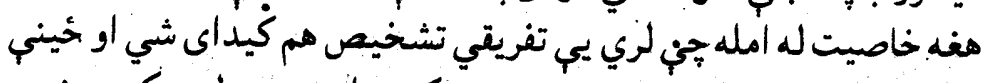

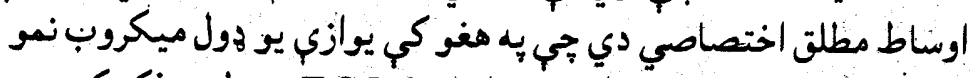

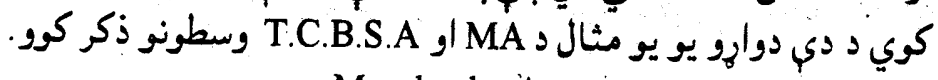
Macckanky Agr
a. bacto pepton $=17 \mathrm{gm}$
b. proteus pepton $=3 \mathrm{gm}$
c. Neutral Red $=0.03 \mathrm{gin}$
d. Bacto lactose $=10 \mathrm{gm}$.
f. Bacto Bile salt No3 $1.5 \mathrm{gm} \%$
g. sodium chloride $=5 \mathrm{gm}$
h. Bacto A gar $=13,5 \mathrm{gm}$
e.crystal Violet $=0.001 \mathrm{gm}$
i. Bacto
j. Destillid water $=1000 \mathrm{cc}$

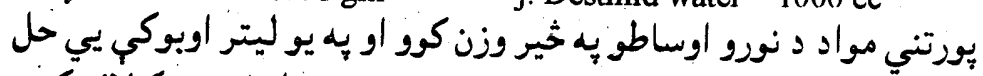

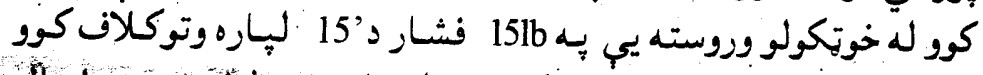

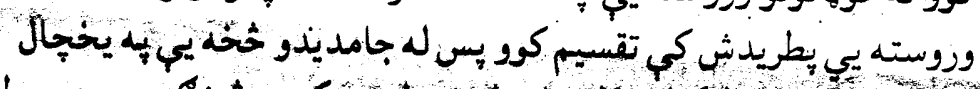

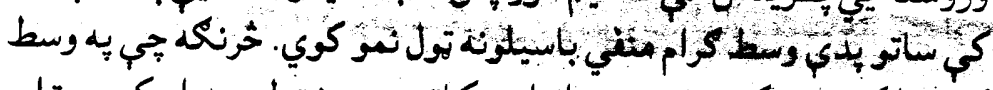

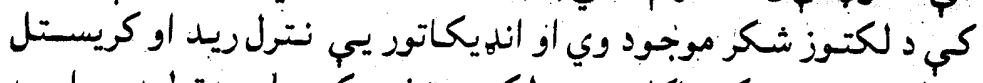

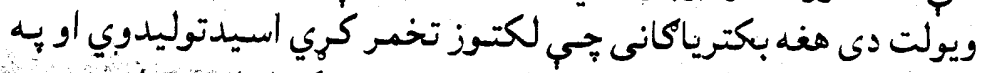

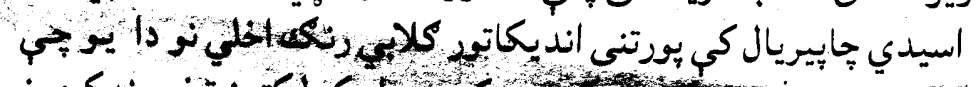
.

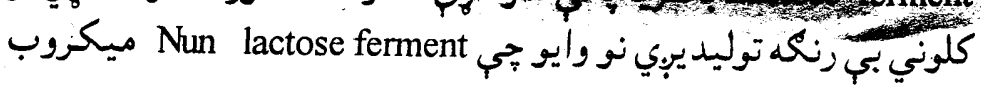

\begin{tabular}{|c|c|}
\hline \multicolumn{2}{|c|}{ T.C.B.S.A } \\
\hline a. Bacto yest extract $5 \mathrm{gm}$ & g. Sodium chloride $10 \mathrm{gm}$ \\
\hline b. Proteus pepton NO3 Defw $10 \mathrm{gm}$ & h. Feric citrate $1 \mathrm{gm}$ \\
\hline c. Sodium citrate $10 \mathrm{gm}$. & i. Bacto bromo thymol blue $0.04 \mathrm{gm}$ \\
\hline d. Sodium thio sulfate $10 \mathrm{gm}$ & j. Bacto thymol blue $0.04 \mathrm{gm}$ \\
\hline e. Bacto OX gall $8 \mathrm{gm}$ & k. Bacto agar $15 \mathrm{gm}$ \\
\hline f. Bacto soCcharose $20 \mathrm{gm}$ & $\frac{1 . D . W 1000 \mathrm{cc}}{\text { m. } \mathrm{pH} 8.6}$ \\
\hline
\end{tabular}




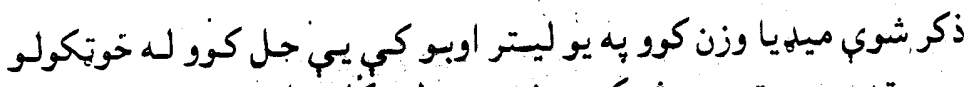

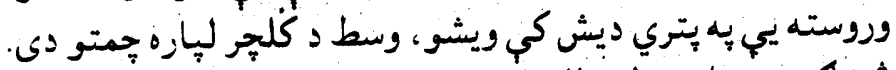

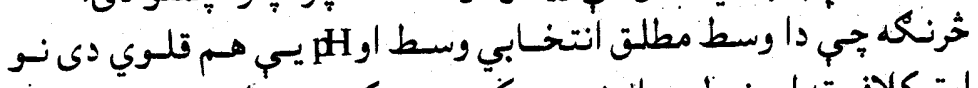

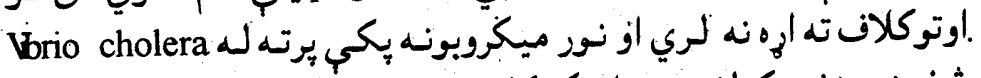

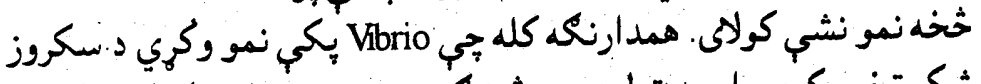

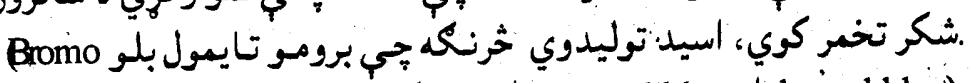

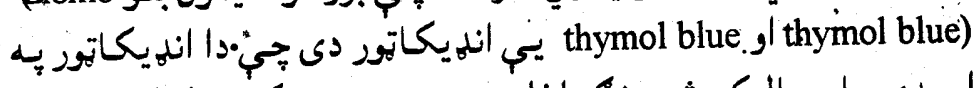

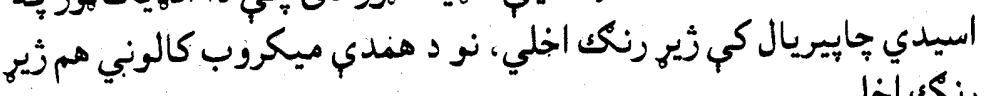
رنك اخلي.

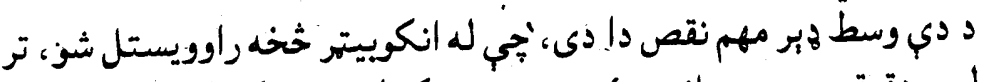

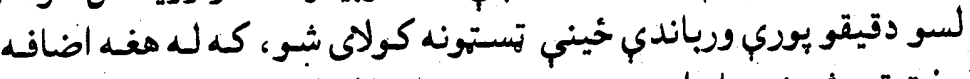

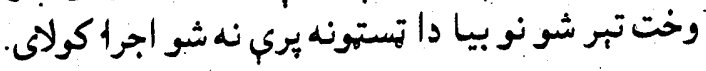




\section{Staining تلوينات}

د ميكروبو ود تفريقي تشخيص او معلومولو يخاطر ميكروسكيوي معاينه

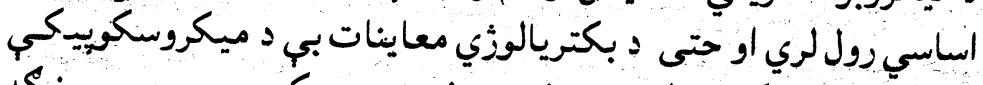

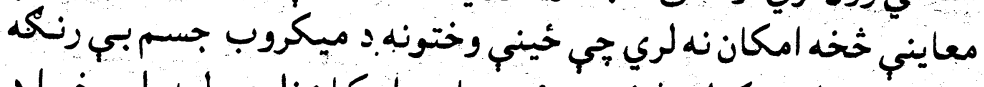

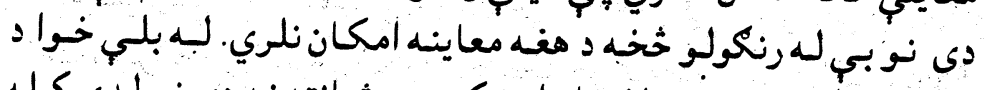

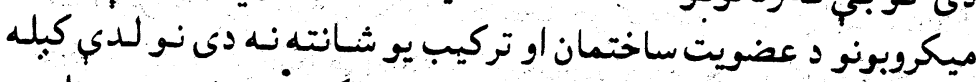

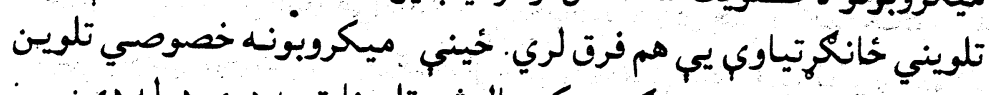

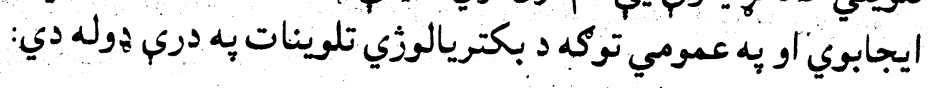

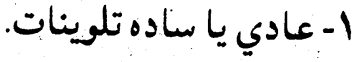

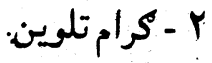

r - r - مشخصه تلوينات

\section{ا - عادي تلوين - متين}

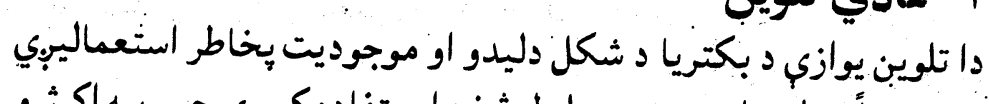

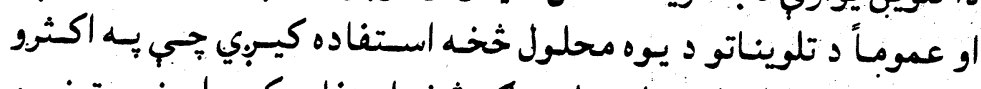

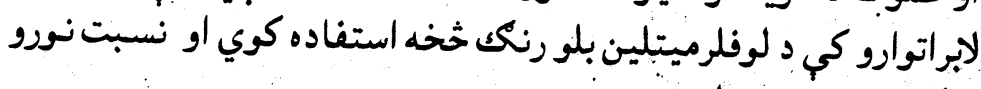

رنكو ته ئي بهتر بولي.

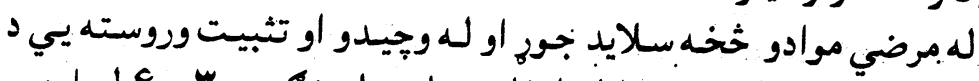

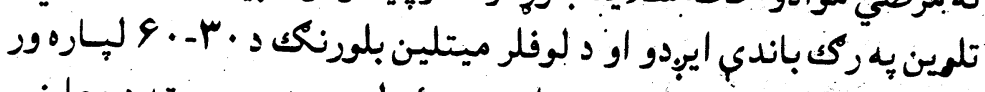

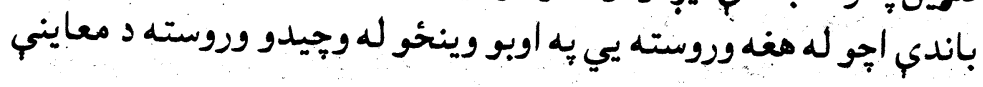

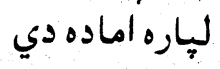

1-Methyline blue Powder $=0,5 \mathrm{gmm}$ 2- Solution Potaium Hydroxide 40=lml $\quad$ 4- Distelled water $=100 \mathrm{cc}$

د لوفلرميتلين بلو د جوريد

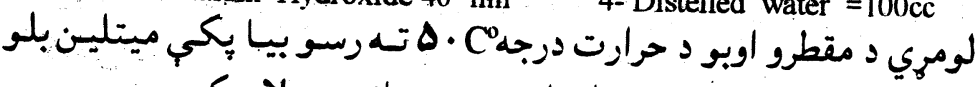

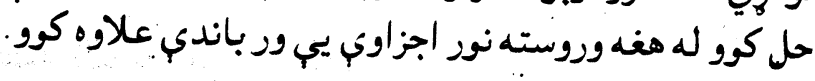

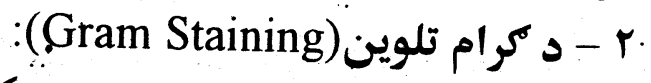

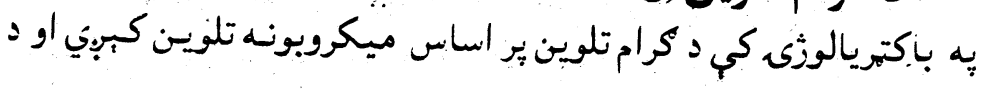




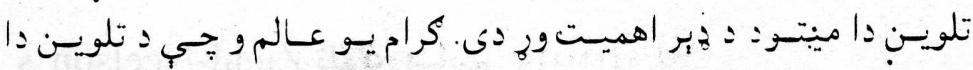

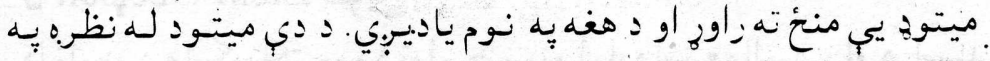

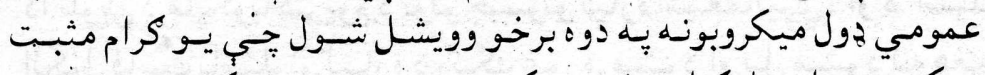

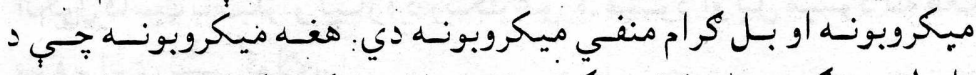

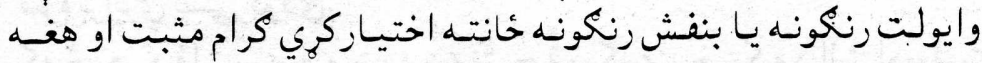

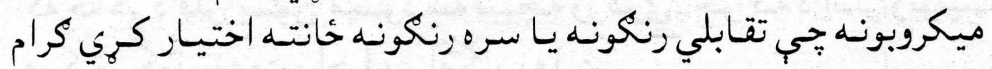

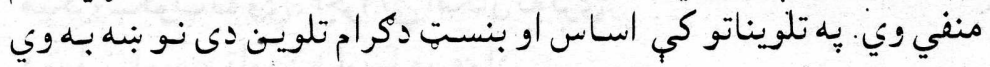

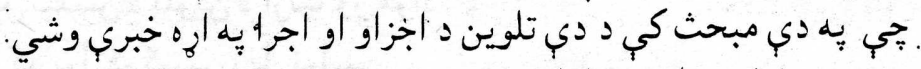

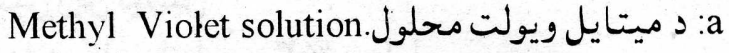

Methyl Violet Poweder $=5 \mathrm{gm}$

Distilled water $=1000 \mathrm{cc}$

له هغه وروسته جي رنكك يه اوبو كي حل شو بيـا يب فلتركوو او د كار

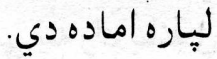

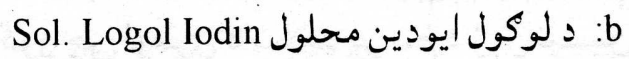

Iodin crystal $=1 \mathrm{gm}$

Potassium Iodide $=2 \mathrm{gm}$

Destilled water $=100 \mathrm{cc}$

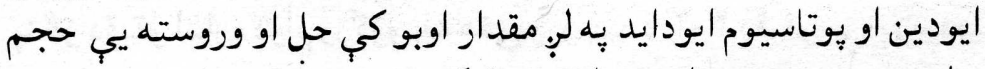

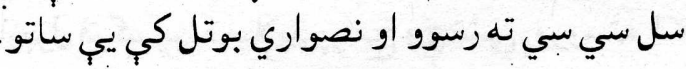

Neutral Red:C

Neutral red powder $=1 \mathrm{gm}$

Sol. Acetic Acid 1\%= 2 cc

Destilled water $=100 \mathrm{cc}$

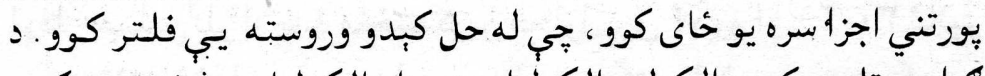

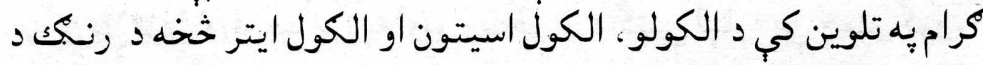

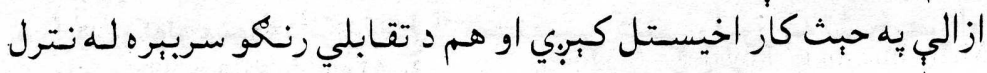

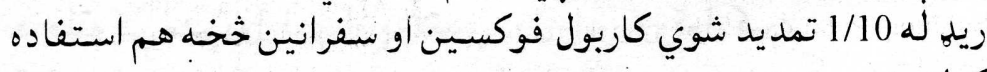
كولایى شو.

r- إ- مشخصه تلوينات:

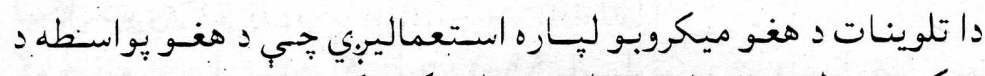

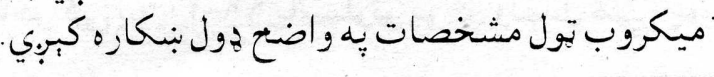




\section{دiehl-Neelson د تلوين:}

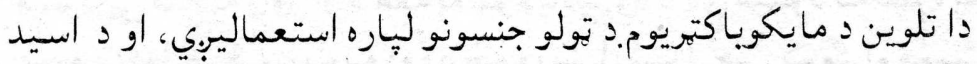

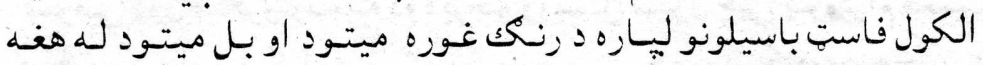
سره برابري نشي كولانى.

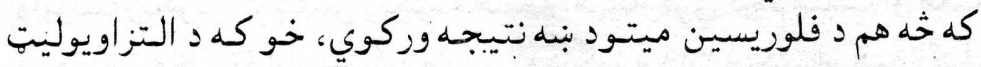

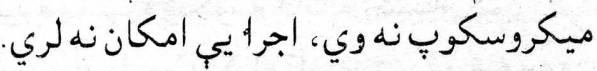

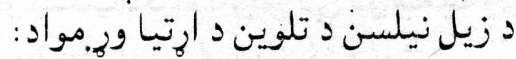

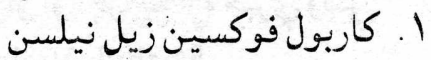

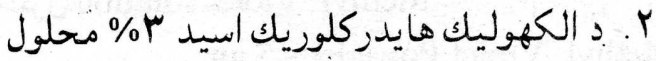
ب. ب. لفلر ميتلين بلو او يا ملخت كائ كرين

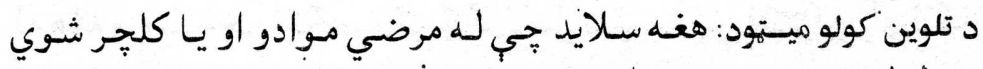

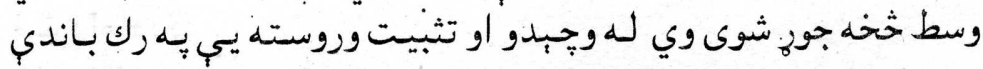

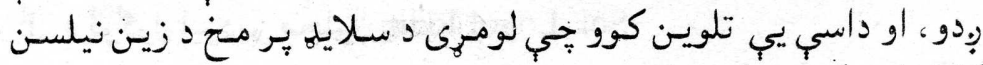

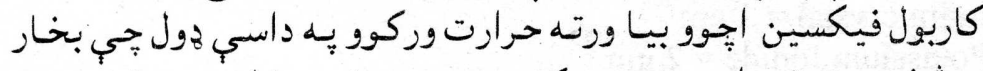

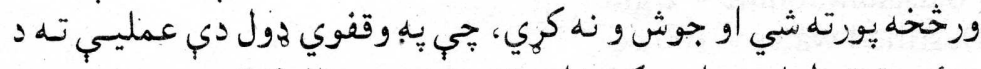

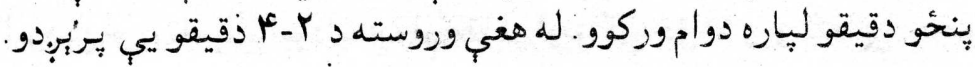

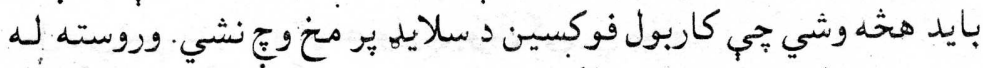

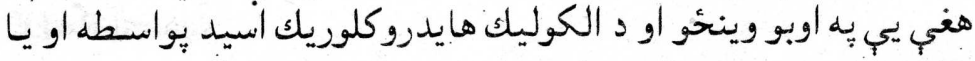

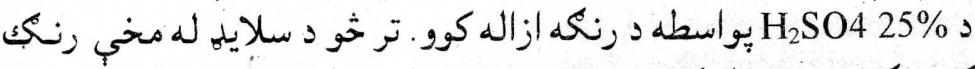

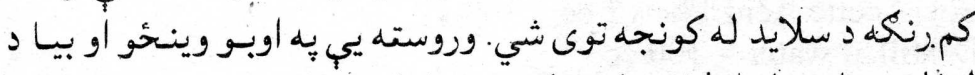

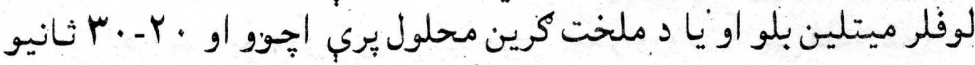

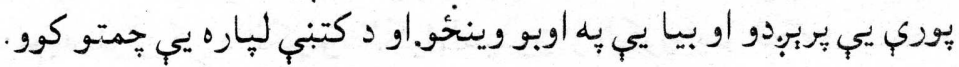

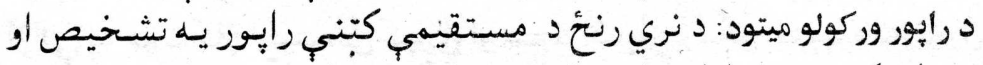

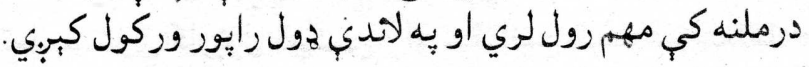

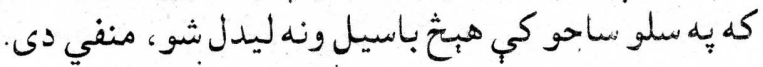

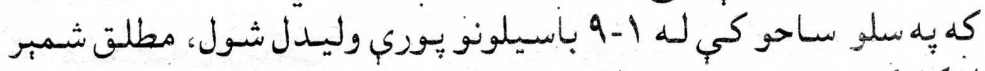
ليكل كببوين

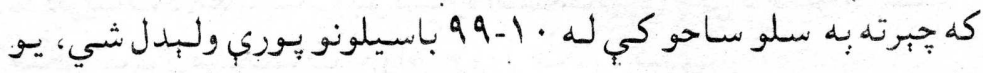
مثبت دي. 


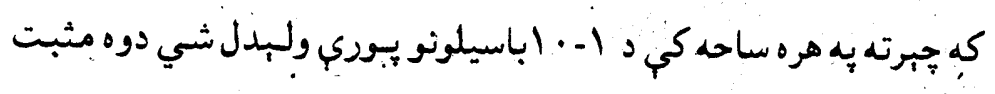

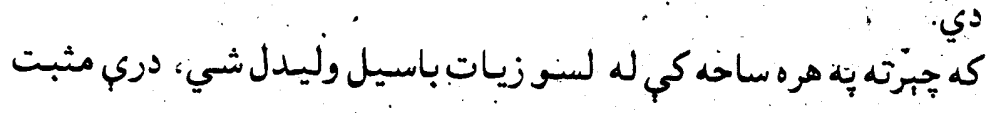
دي. د درنك جورولو ميتوج:

1- Basic fuchsin $=1 \mathrm{gm}$

2-. $95 \%$ Ethyl alcohol $=10 \mathrm{cc}$

3- Phenol $=5 \mathrm{gm}$

4- Destilled water $=100 \mathrm{cc}$

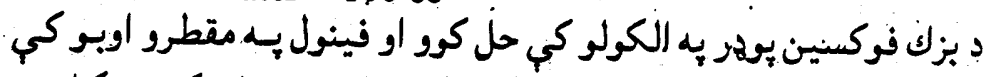

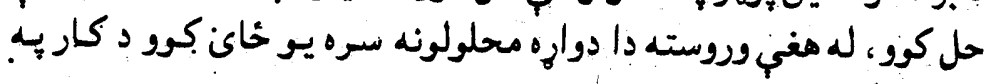

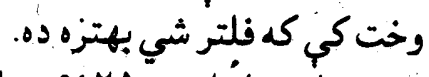

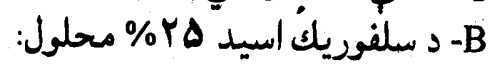

1- Concentrate $\mathrm{H}_{2} \mathrm{SO} 4=25 \mathrm{cc}$.

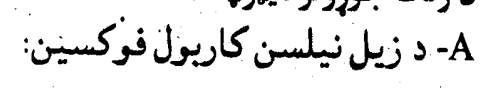

2- Destilled water $=75 \mathrm{cc}$

لومرى يه فلاسك كي مقطري اوبو اجوو، وروسته له هغي سلغوريك اسيد.

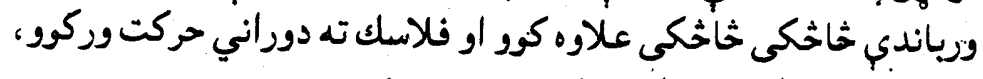

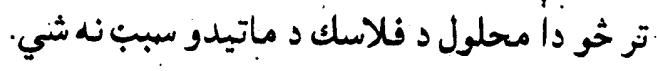

Methellin blue powder $=0.5 \mathrm{gm}$

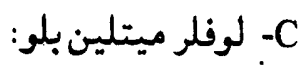

$1 \%$ Potacium Hydroxide $=1 \mathrm{cc}$

Ethyl Alcohol $=30 \mathrm{cc}$

Destilled water $=100 \mathrm{cc}$

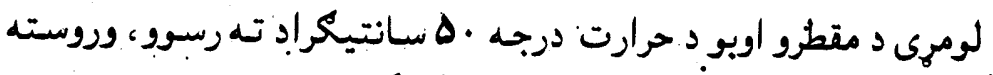

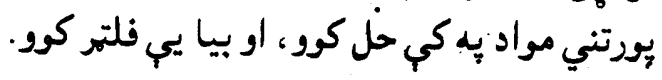
د نايسر تلوين:

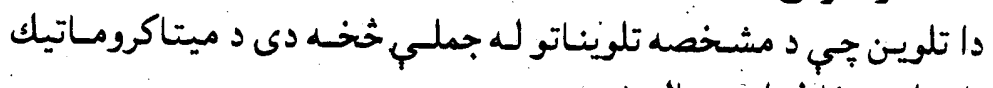
باسنيلو بِه خاطر استعماليِّين.

Solution Nissar A د رئك جورلو مينوه:

1. Methyllin blue $=1 \mathrm{gm}$

2. Absolut alcohol $=50 \mathrm{cc}$ 
3. Glacial Acitic Acid $=50 \mathrm{cc}$

4. Destilled water $=1000 \mathrm{cc}$

Solution Nissar B

1. Crystal violet $=1 \mathrm{gm}$

2. Absolut alcohol $=10 \mathrm{cc}$

3. Destilled water $=300 \mathrm{cc}$

Solution Nissar C or Bismark Brown

1. Bismark brown powder $-0,2 \mathrm{gm}$

2. Destilled water $=100 \mathrm{cc}$

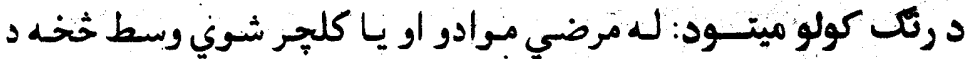

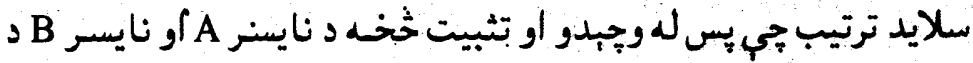

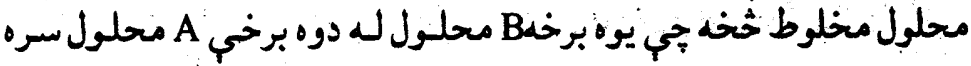

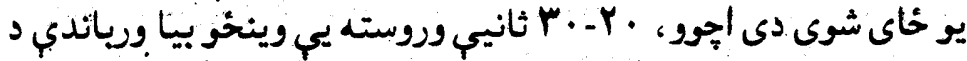

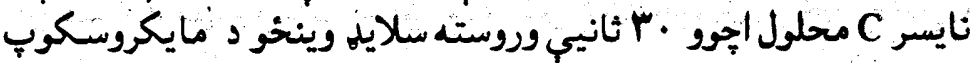

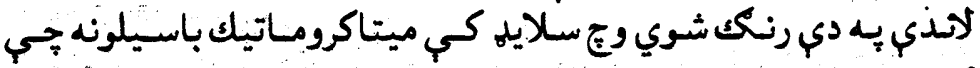

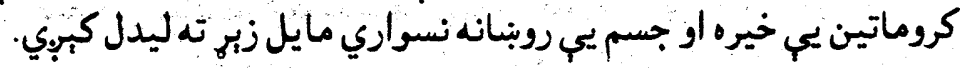




\section{STAPHYLOCOCCUS}

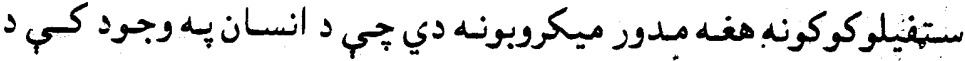

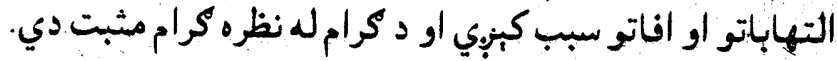

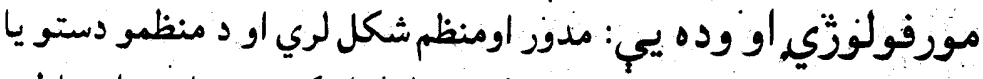

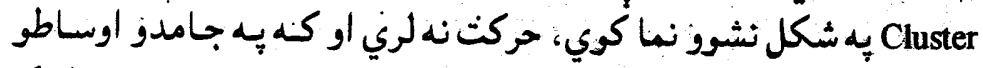

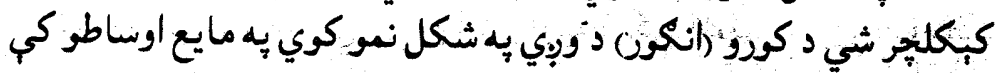

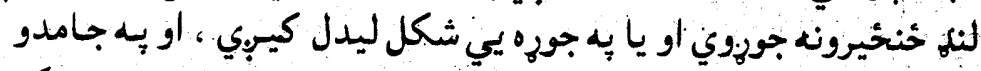

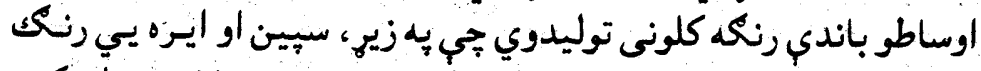

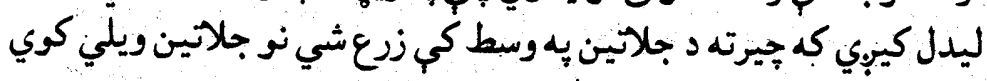
يعني د جلاتيناز انزايم افرازوي.

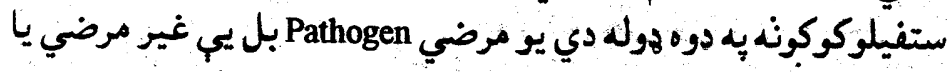
Saprofite

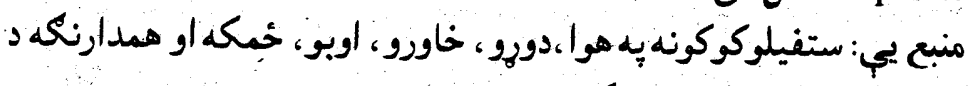

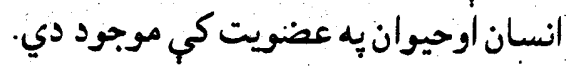

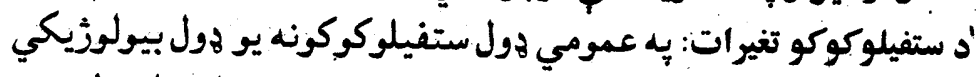

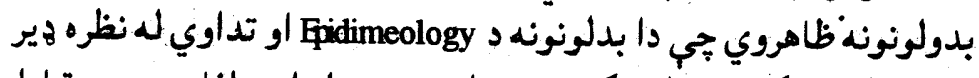

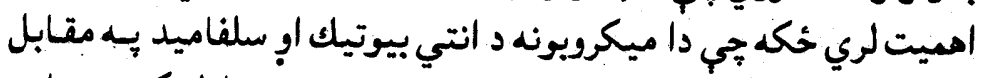

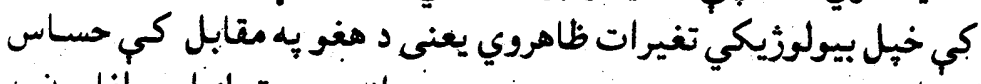

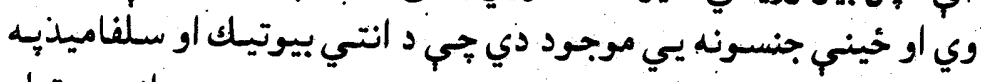

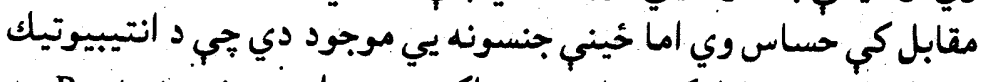

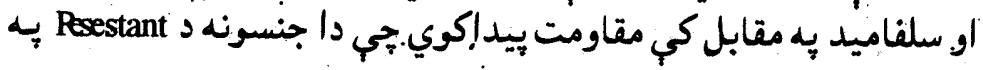

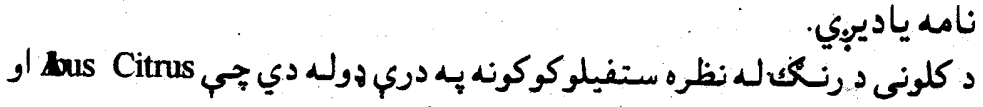

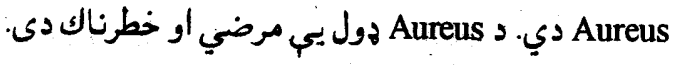
Staphylococcus aureus

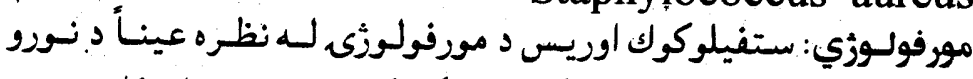

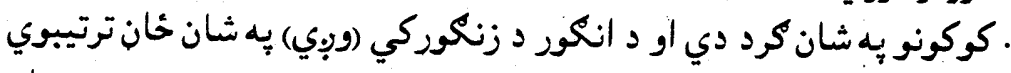

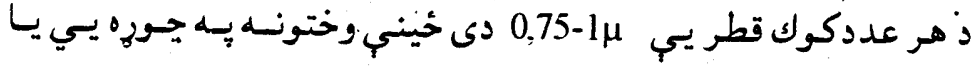




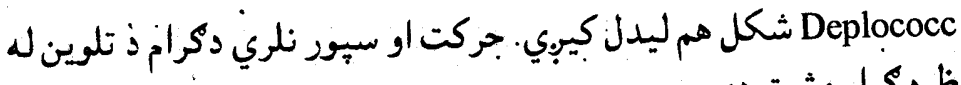
نظره كرام مثبت دي.

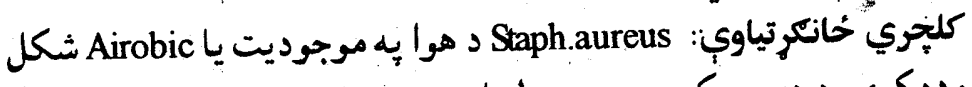

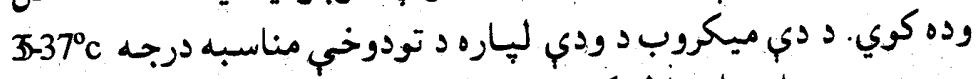

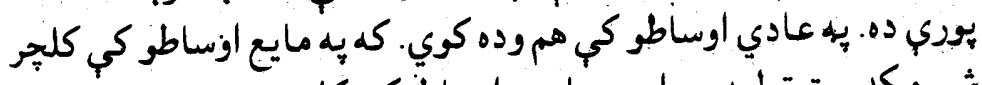

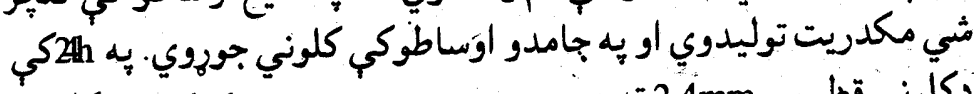

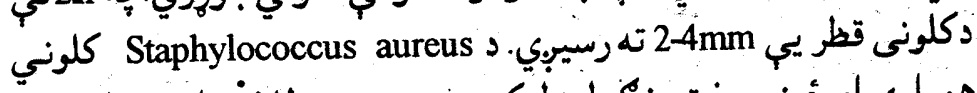

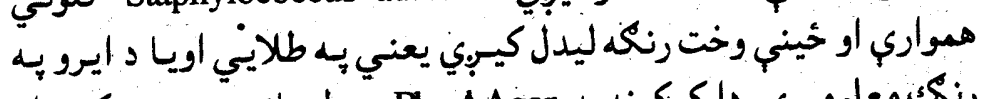

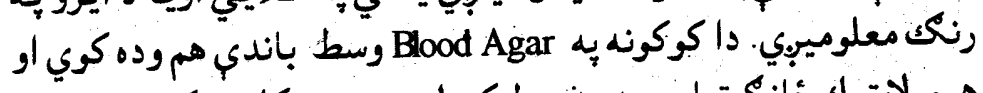

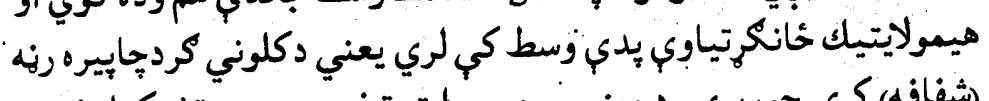

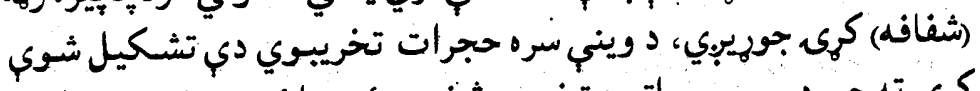

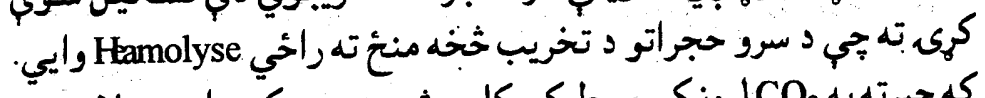

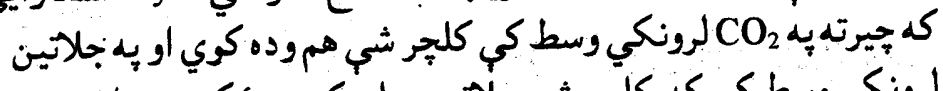

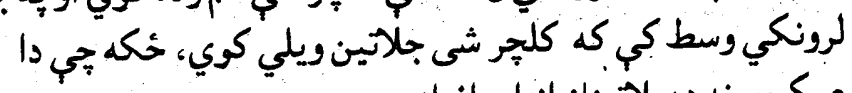
ميكروبونه د جلاتيناز انزايم إفرازوي.

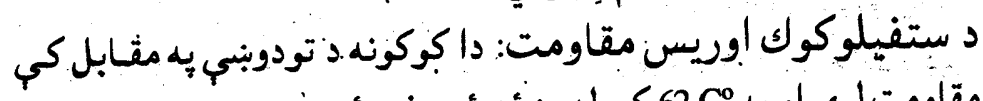

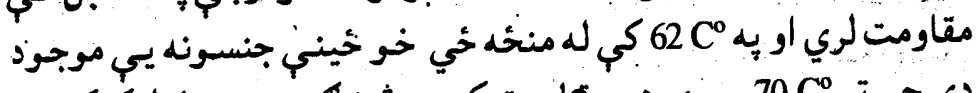

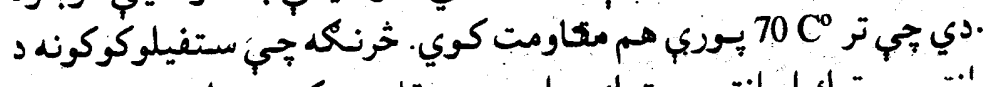

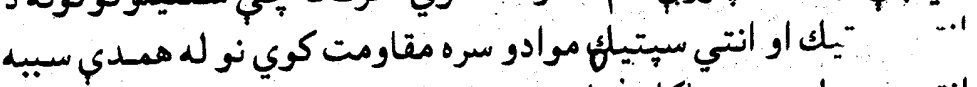

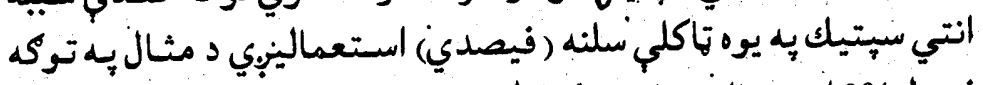

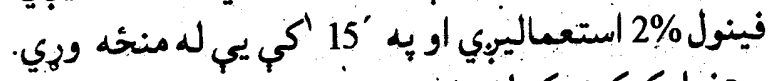

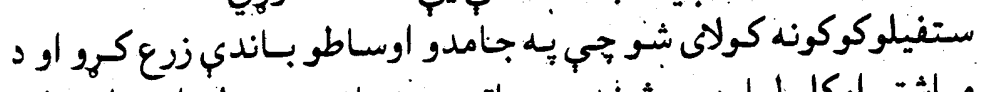

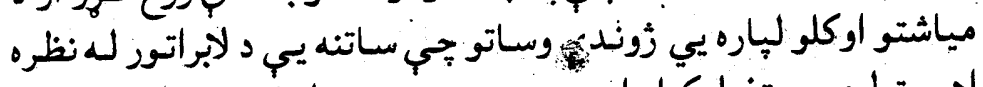

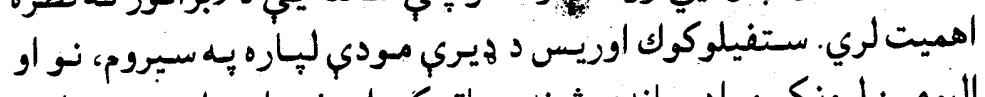

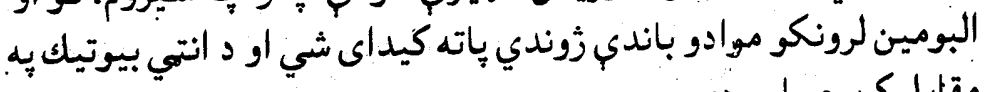
مقابل كن حسابِ دي. 
كيمياوي تعاملات: كه ستفيلوكوك اوريس يه مختلفو كازبوها يدرينتو

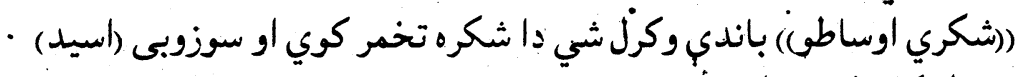
يرته له كماز خخه توليدوني.

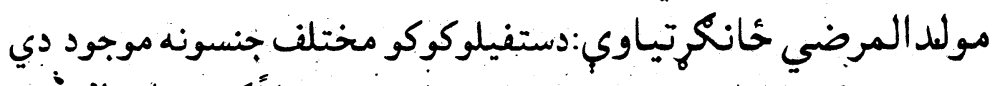

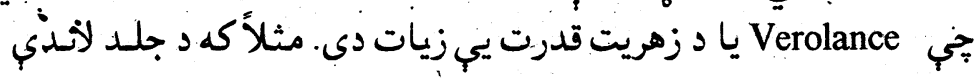

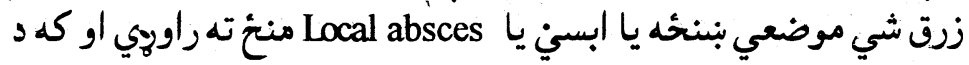

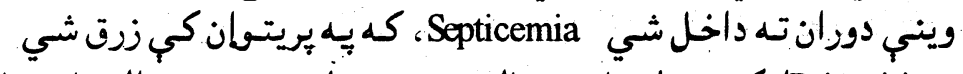

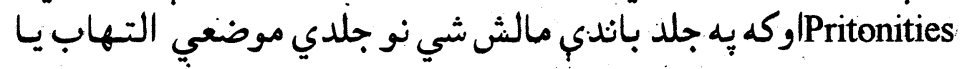
Local Inflamation

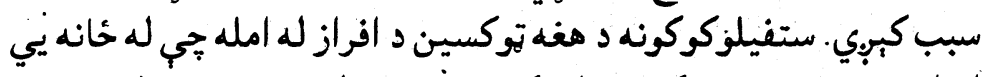

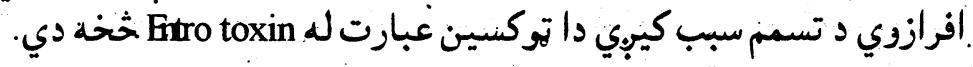

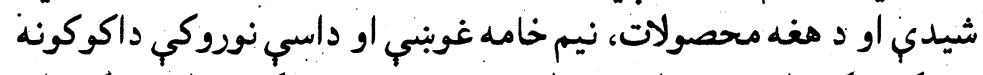

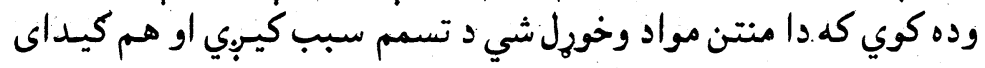

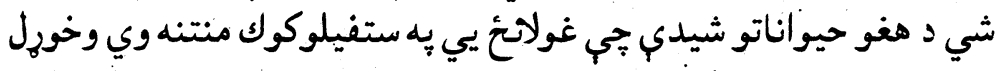
شي هم د تسمم سبب كيبري.

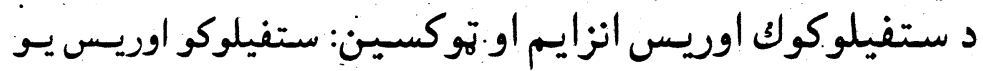

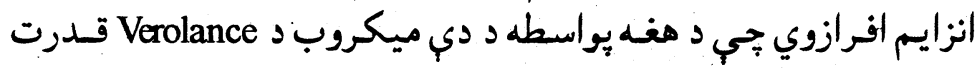

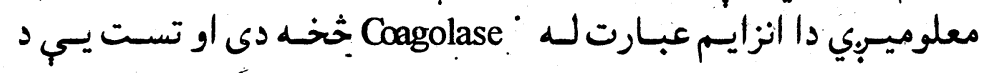
Coagolase test مرضي ستفيلوكو كونه سره تفريقي تبخخيص كيبري.

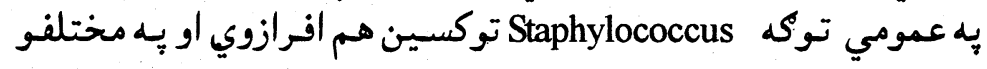
هولونووي. بي مج أو رهيمولايزن يي د موضعي التهاباتو سبب Hemolysin $\alpha-\beta-\gamma: 1$ كِبري.

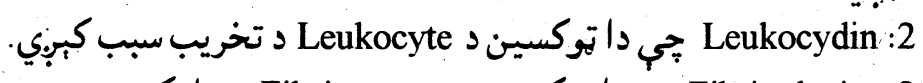
3 : جي دوا توكسين د ويني د Fibrinolysin كبري. 
4: : Entrotoxin : دا توكسين د معدي او امعا د التهاب سبب كبوبي او تسمم منتخ ته راوري.

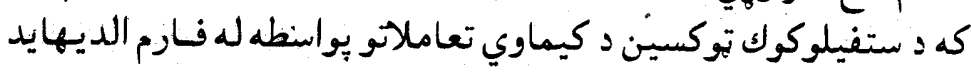

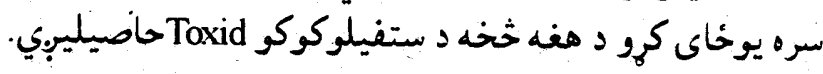

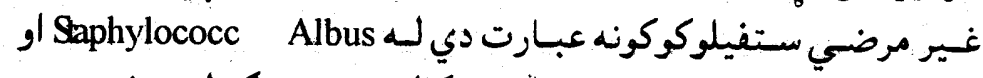

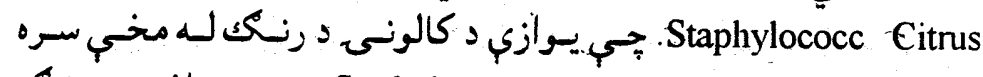

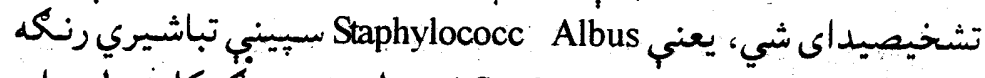

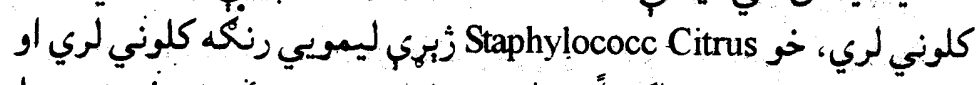
Staphylococc Albus

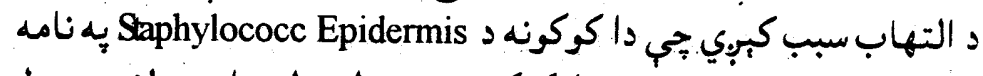

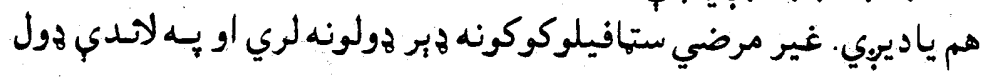

Gaffika Tetragen

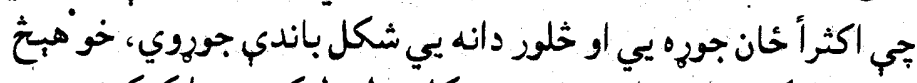

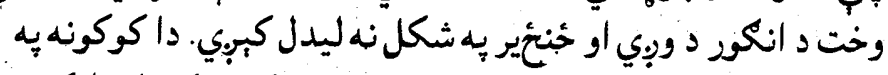

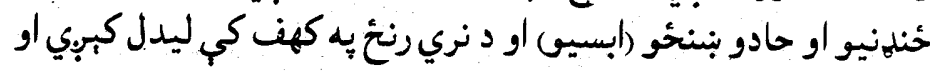

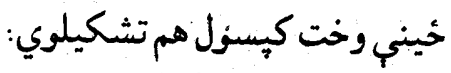

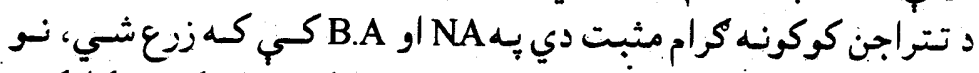

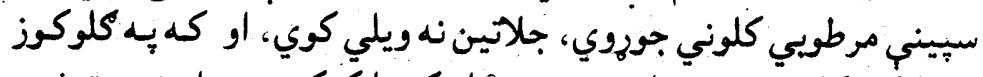

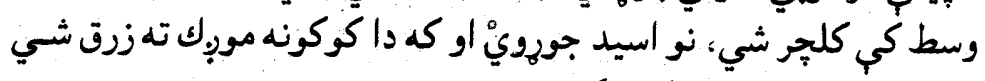

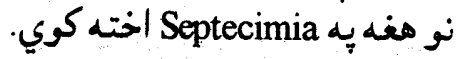
Macrococcus Luteus

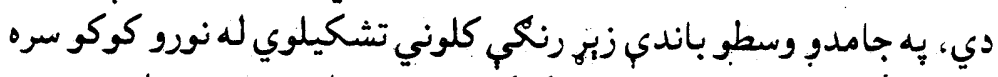

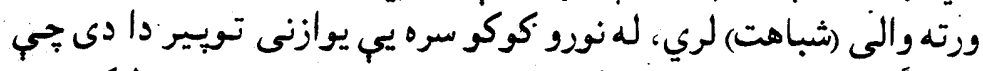

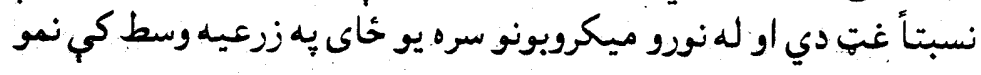
كوي. هacrococcus Luteus سرونه :Micro coccus Urea

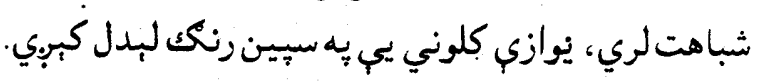


: دا كوكونه اكثرأ د معدي يـه عصاره كي يبيدا

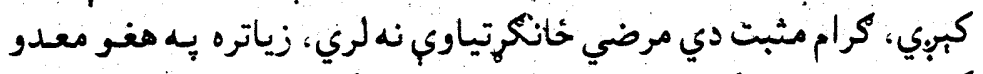

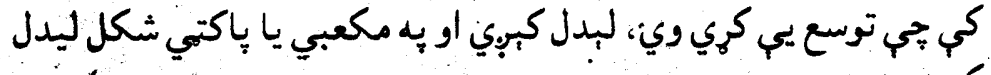
كبربي.

\section{د ستفيلوكوكونو لابراتواري نشخيص:}

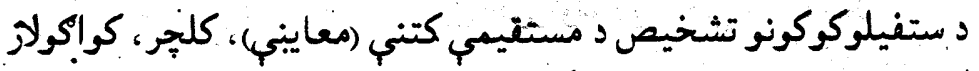

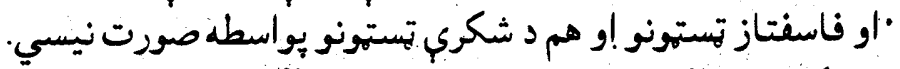

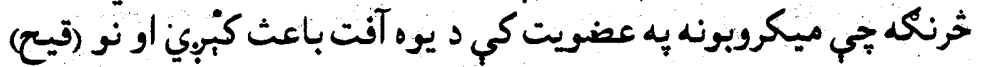

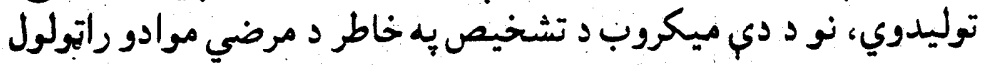

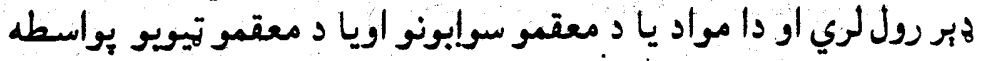

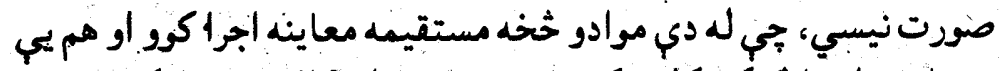

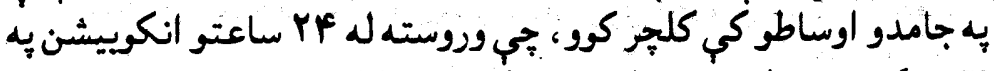

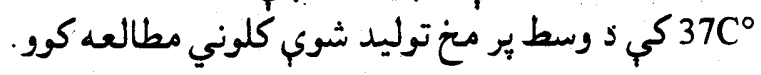

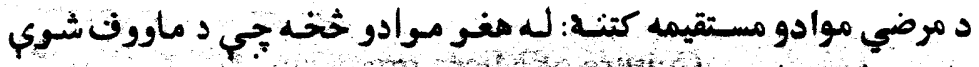

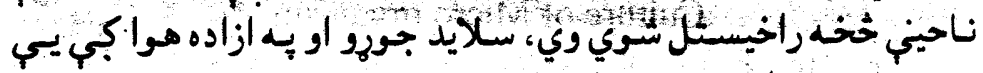

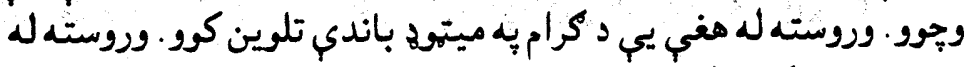

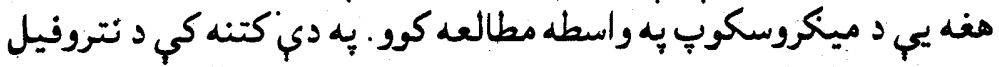

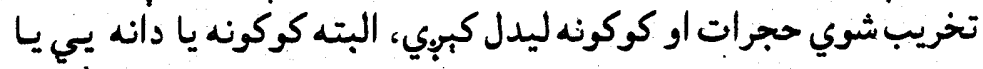

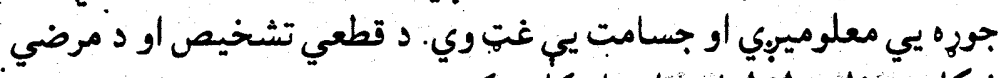

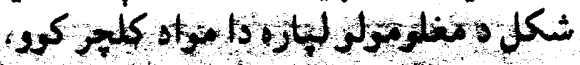
د مكام نلوين سامان أو ريجتثب يبي

دوايوليت رنكك

$$
\text { كرام ايودين }
$$

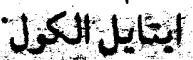
مقطري اوبه
باك سلايد لوبري

د سيرين لمبي

د تلنوين رك

سفرانين يا د كاربول فوكسين زنكك

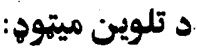
. sil سلايدجوزوو او وروسته يي ازاده هوا كي وجوو او وزوسته له هنه 
ثخده دا سلايد د هريوي يه ورانكه باندي داسي تثبتور جي سلايد دري

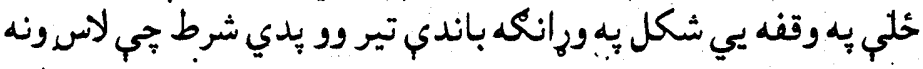
سوخي. r ب سلايد يرمخ د30 ثانيو ليّاره لهوايولت رنكو خخه اجهور اووروسته ي بي ايسته كور.

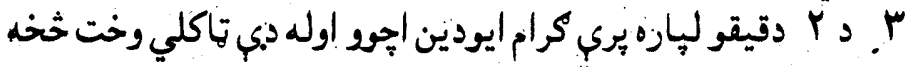

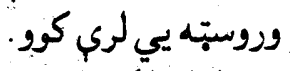

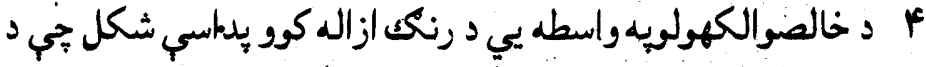

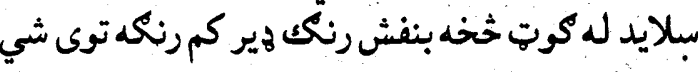

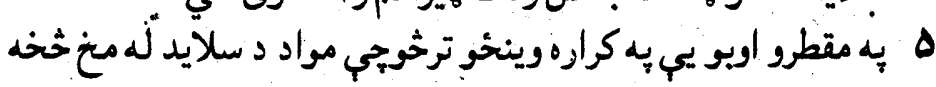
ونه وينخل شي.

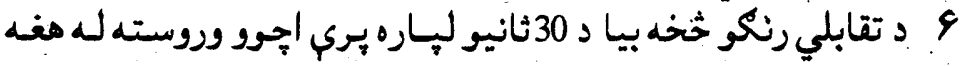

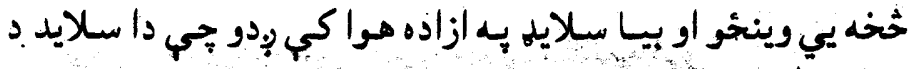

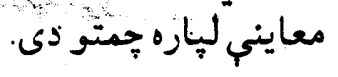

دميكروب زرع كول Culture of Micro organism

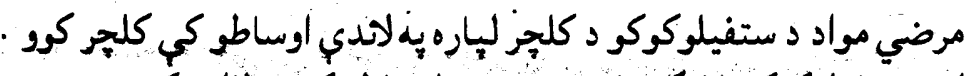

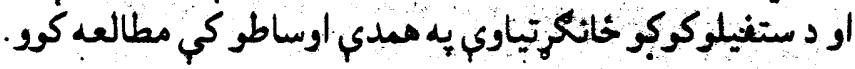

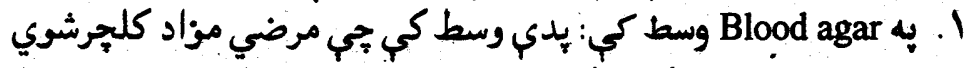

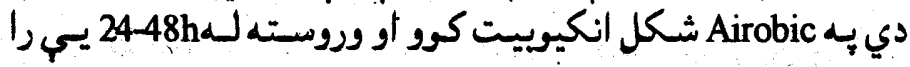

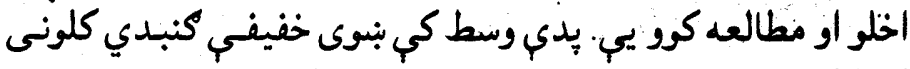

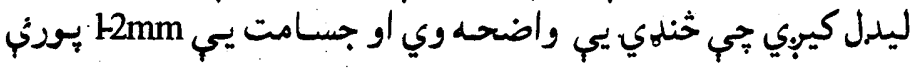

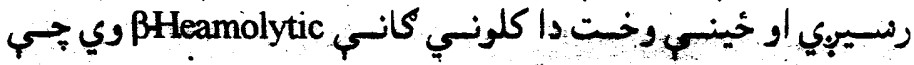

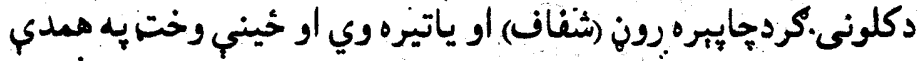

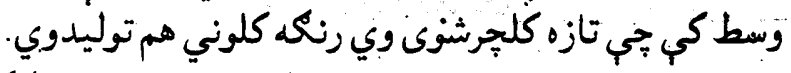

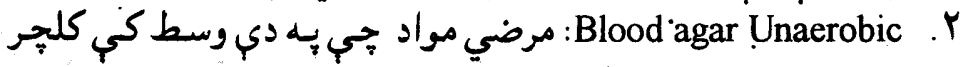

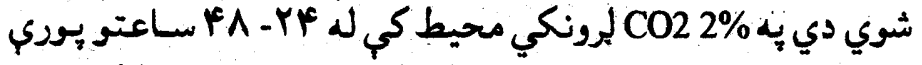

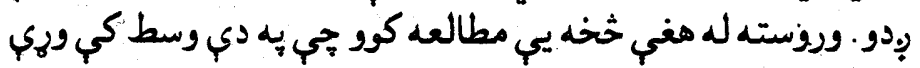

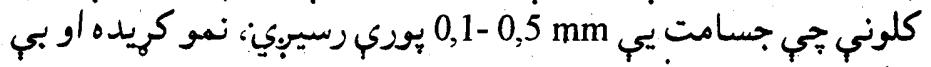

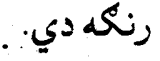


: Macckanky bile salt agar

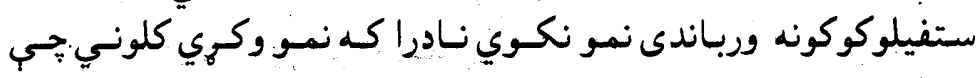

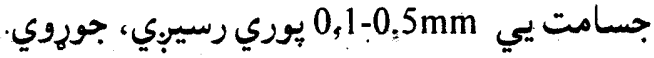

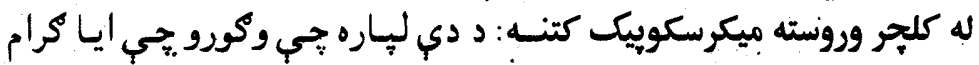

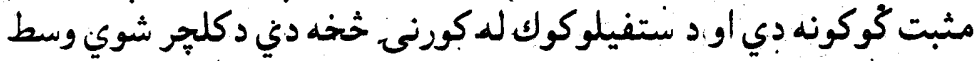

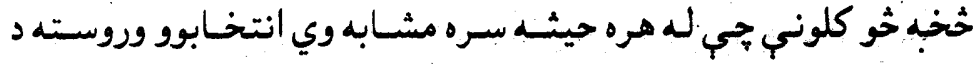

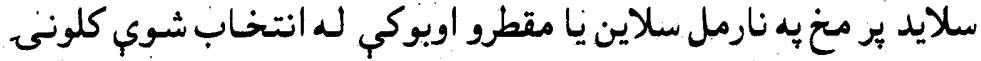

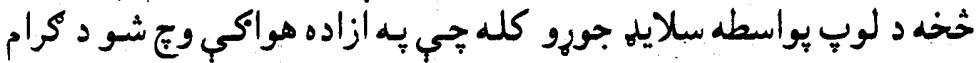

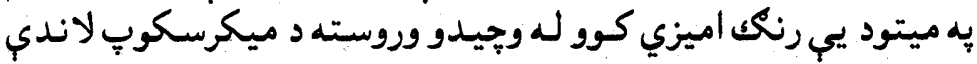

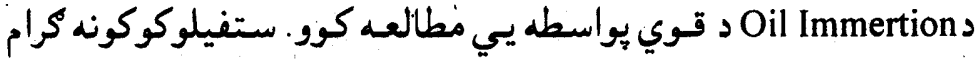

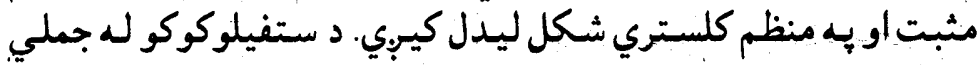

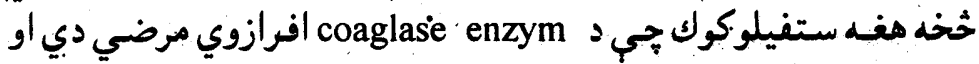

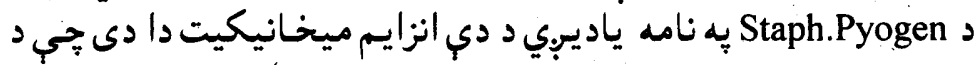

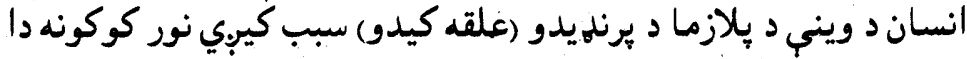

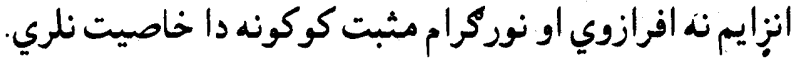

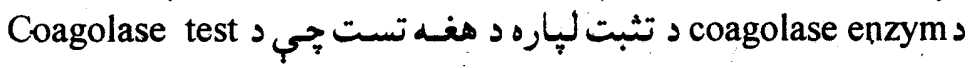

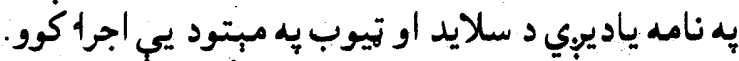
Slide agglutination test ,Slide coagolase test

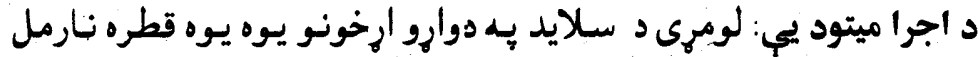

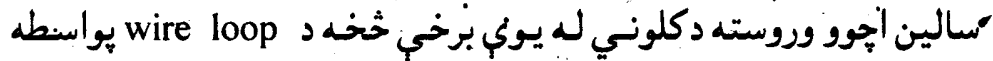

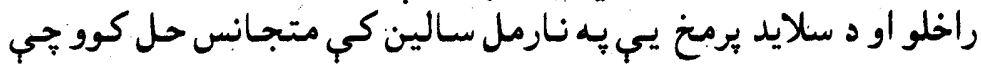

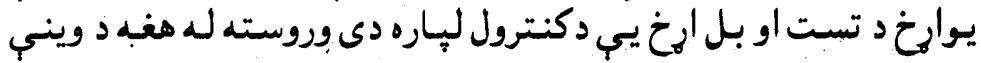

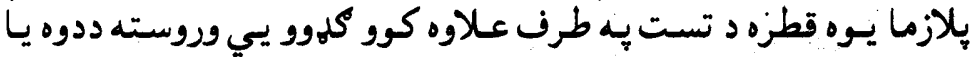

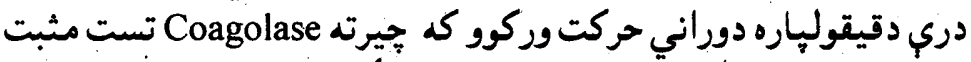

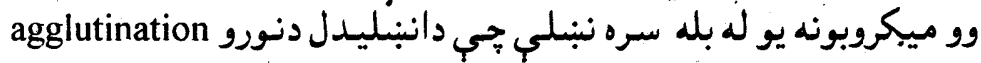

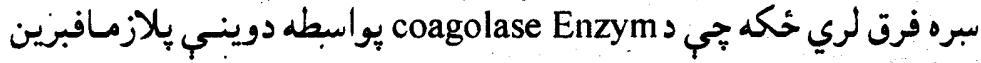

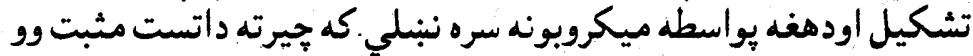

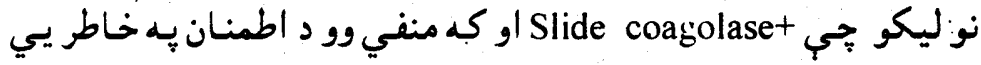
تيوب كوائولار تست أجراكوو 


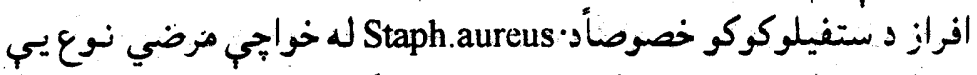

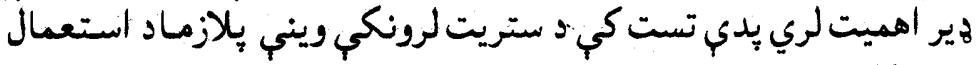

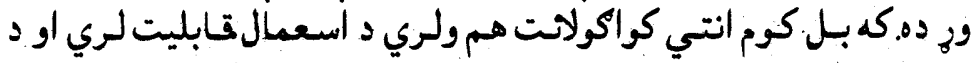

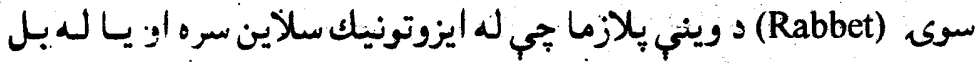

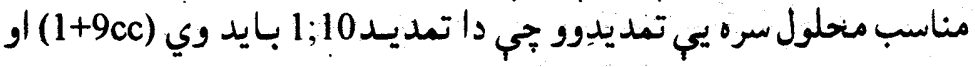
د هغه يواسطه تست اجرا كوو.

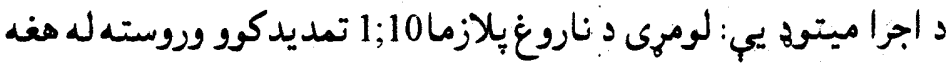

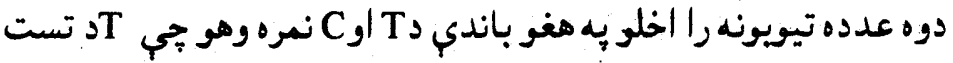

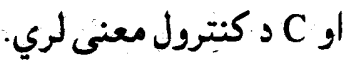

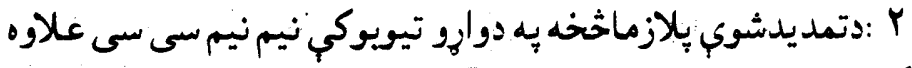

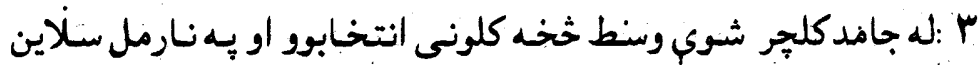

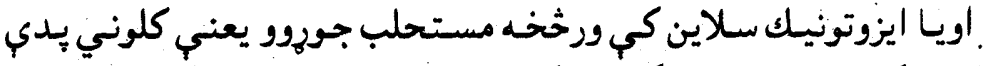

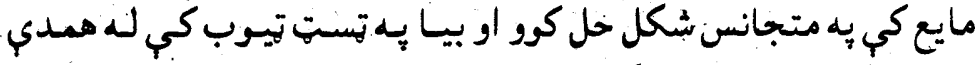

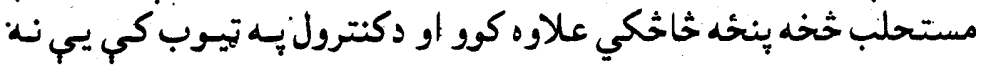

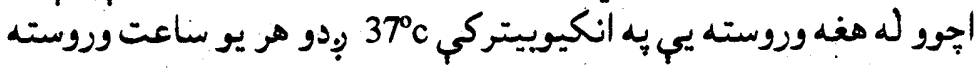

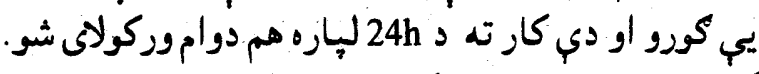

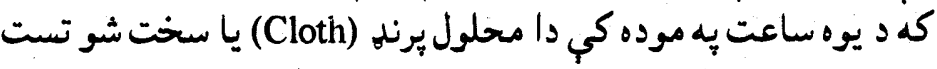

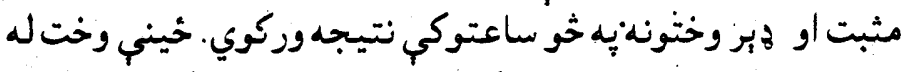

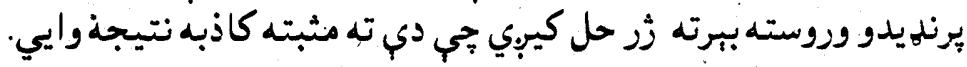
False positive

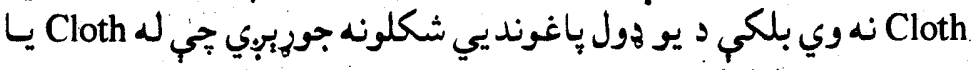

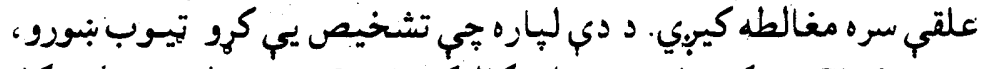

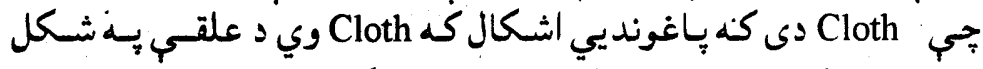

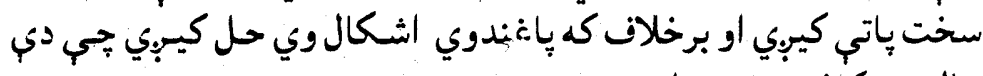
حالت ته كاذب مثبت وائي 
تباكئ False nigative

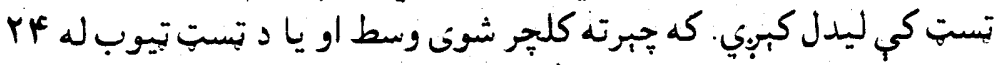

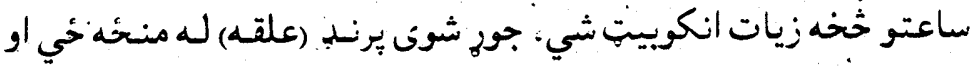

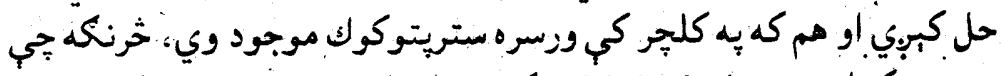

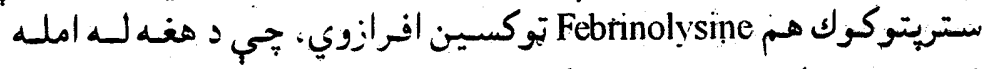
فبرين برنديدلائ شي، نو منفي كاذب حالت ليدال كبريني.

\section{Phasphatase Test}

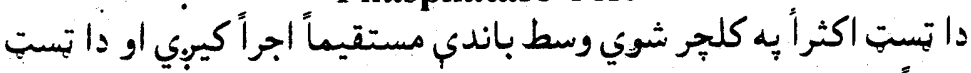

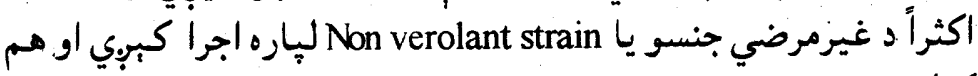

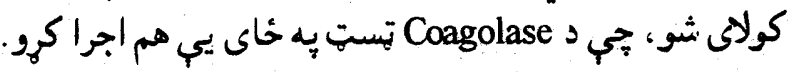

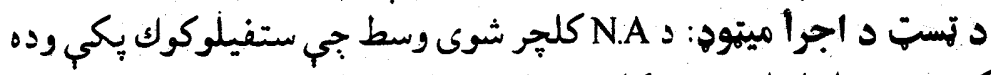

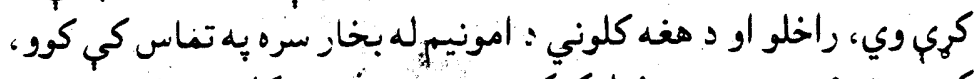

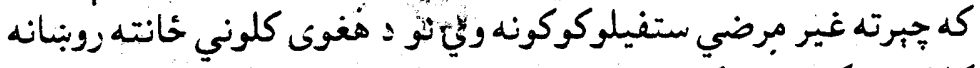

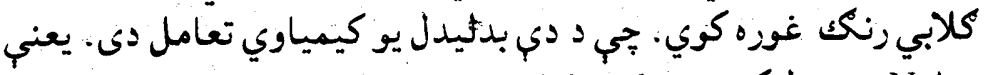

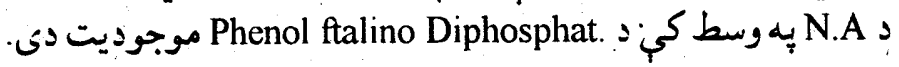

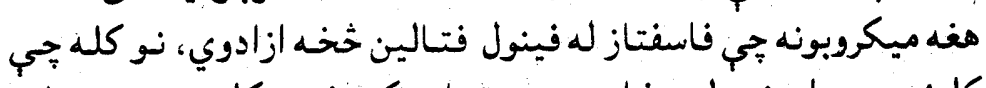

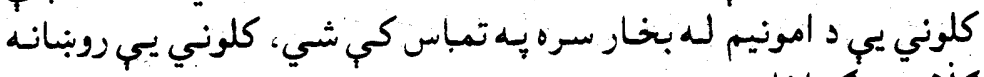
كلابي رنئك اخلي.

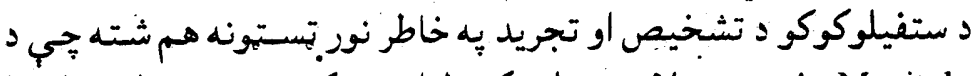
كبوي Manitol كَبِي.

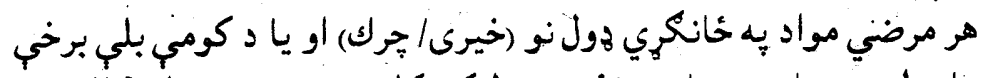

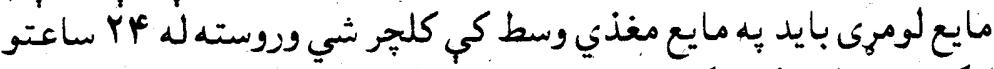

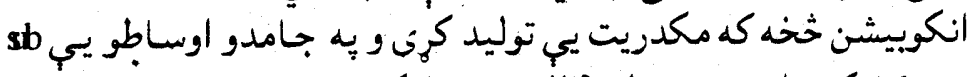
culture

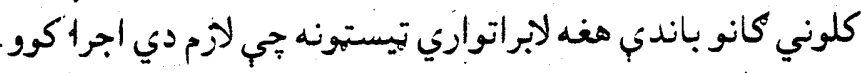




\section{ستريينتوكوكونه (Streptococcus)}

مورفولوزي:

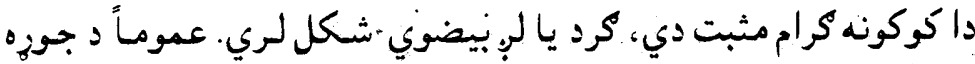

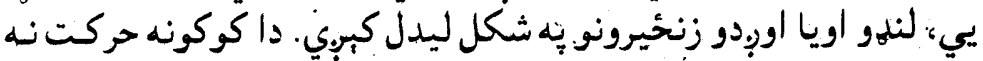

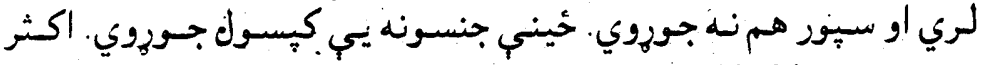

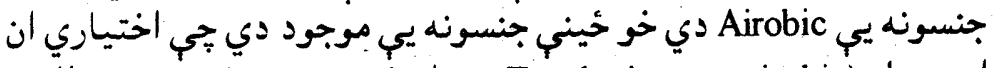

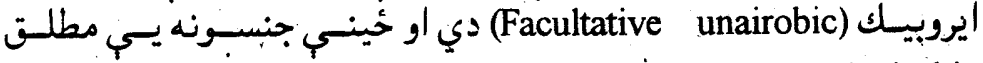
Unairobic

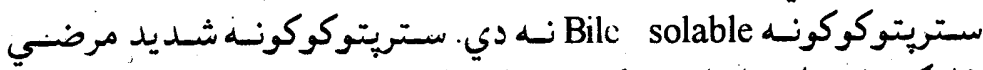

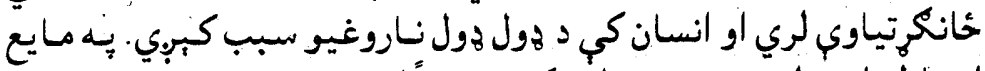

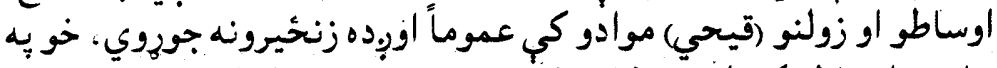

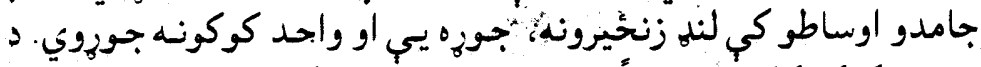

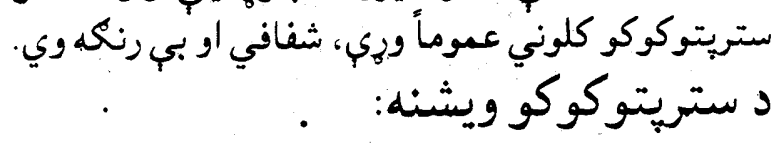

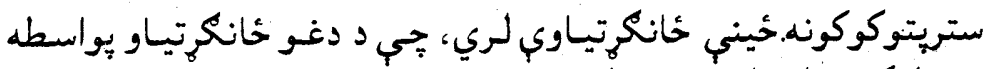

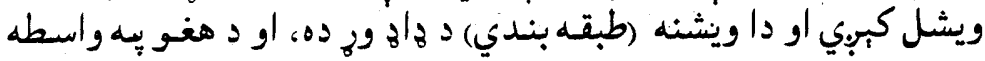

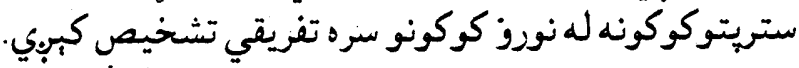

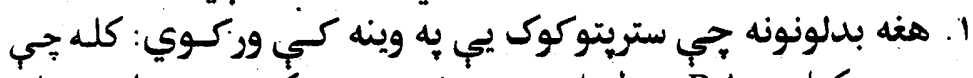

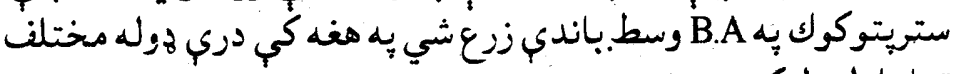
تعامل ليدل كبربي:

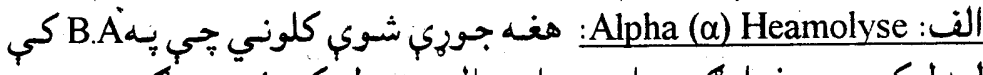

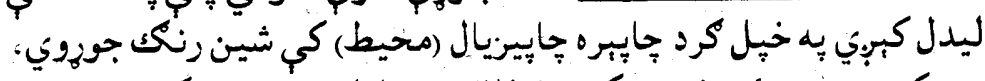

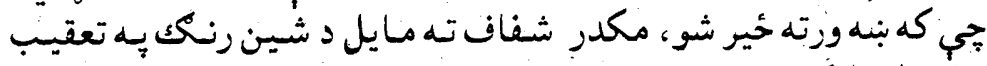

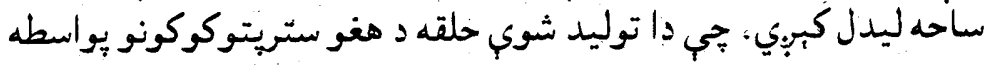

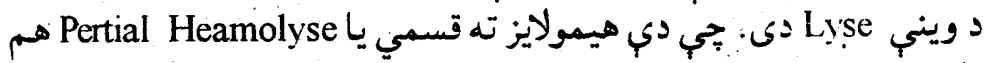

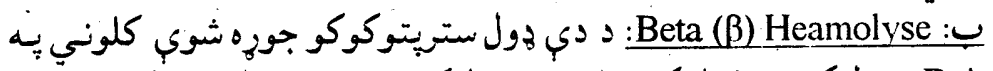

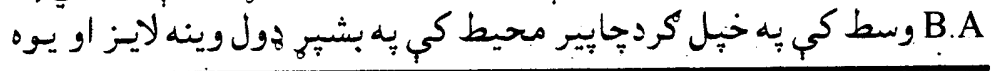




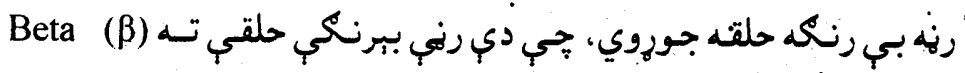
Heamolyse

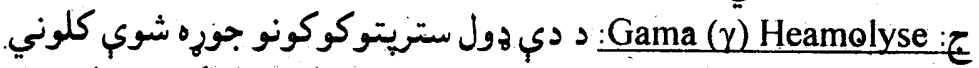

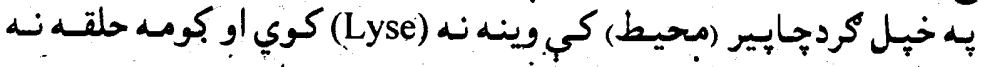

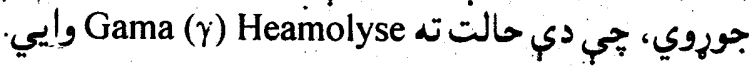

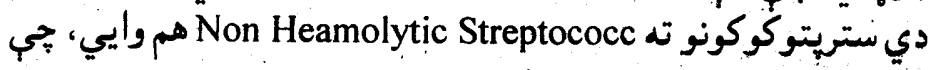

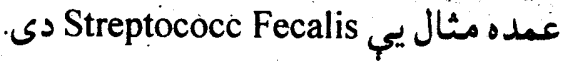

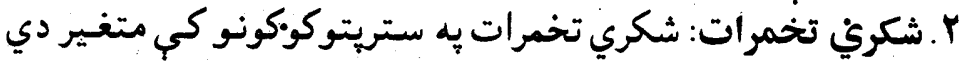

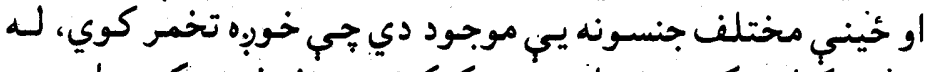

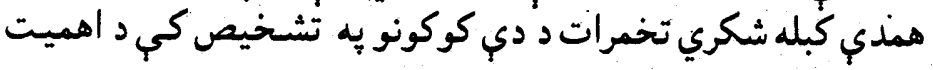
ور نه دي.

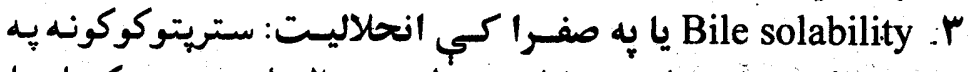

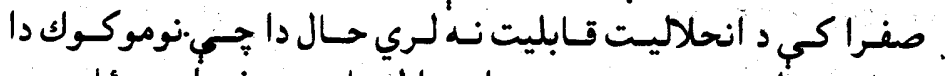

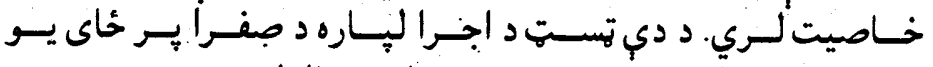

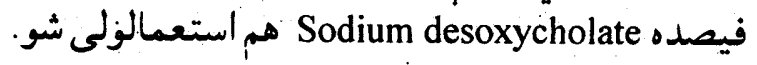

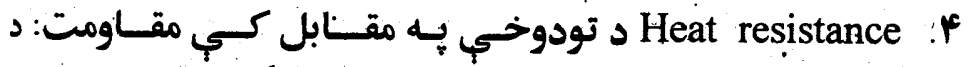
ستريتوكوكونو خيني جنسونه د حرارت يه مقابل كي مقاومت بنيئ يه

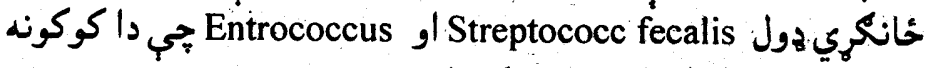

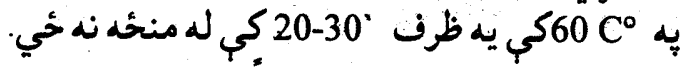

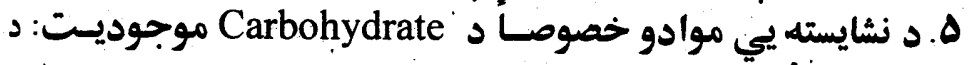

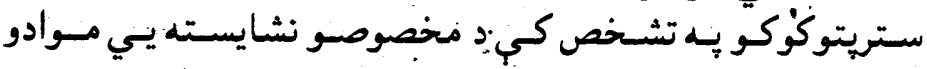
موجوديت هم مرسته كوي. ن-substance

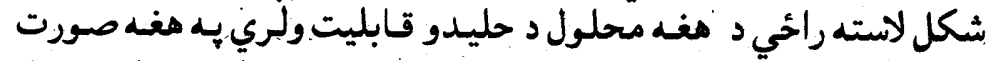

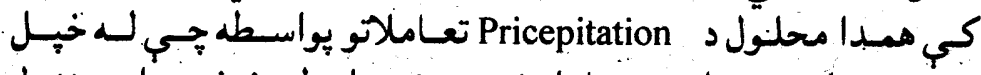

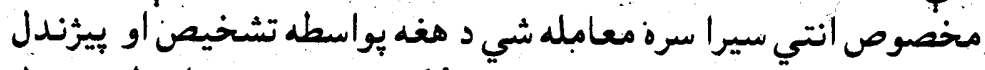

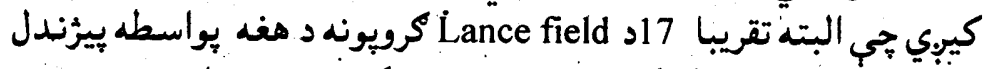

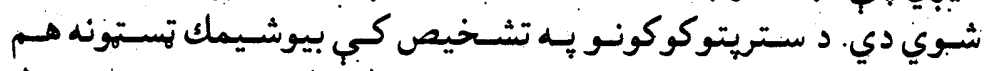

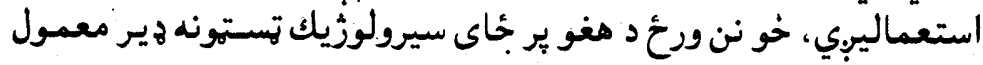




\section{Streptococc Pyogen or Streptococc Heamolytic}

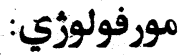

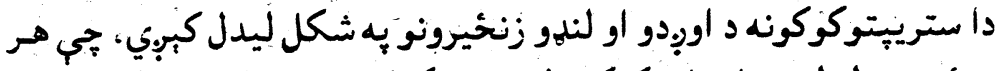

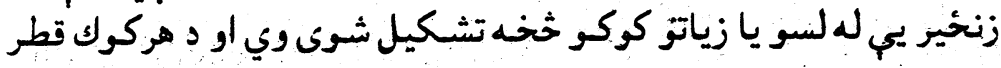

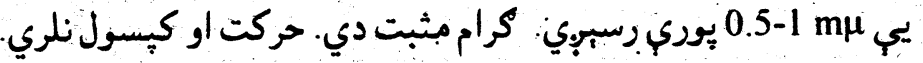
كلجحري خحانكرتياوي يبي:

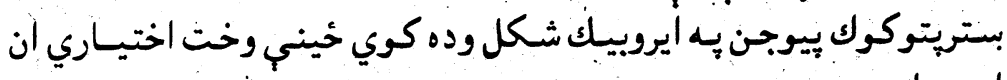
ايروبيك دي.

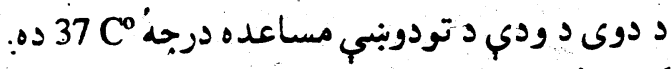

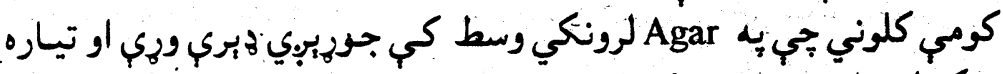

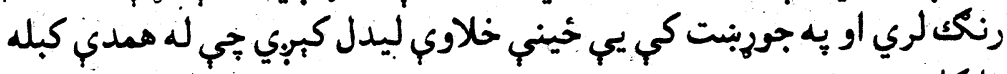

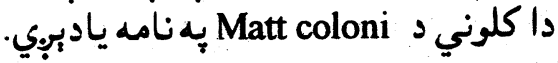

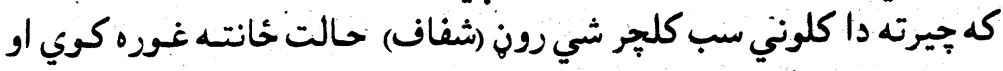

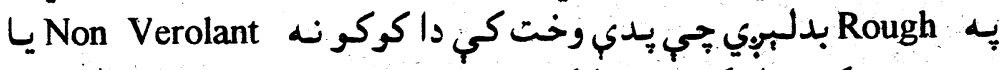

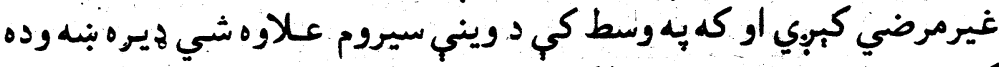

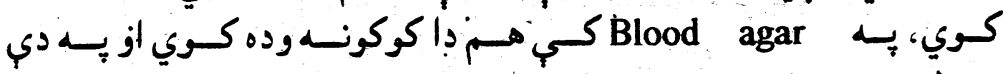

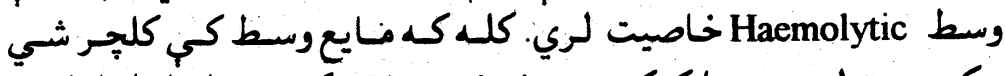

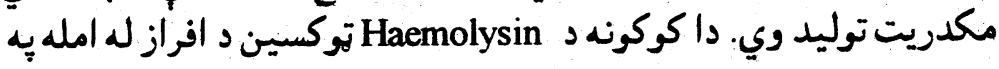

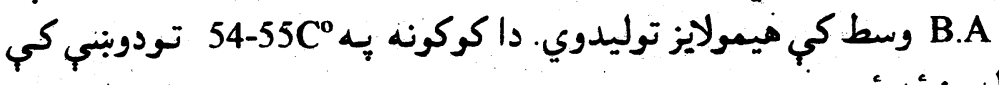
له منخيه خي. انتيجنيك خانكيرتياوي يني: Precipilation د Lance Field

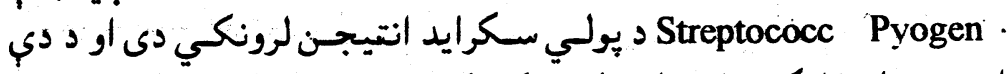

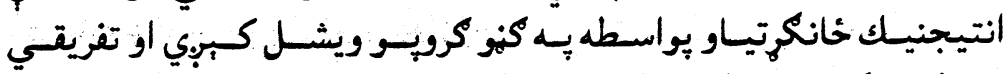

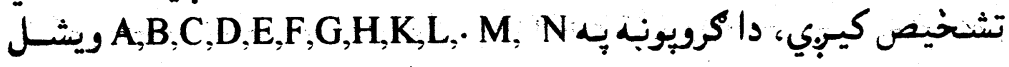

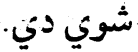


او : Enzyme سشرويتوكوك بيوزن يو شمير زيات بيولوزيكي

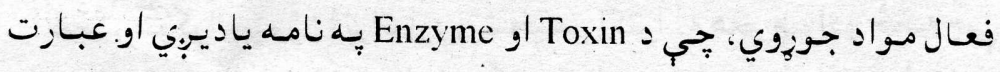
دي له:

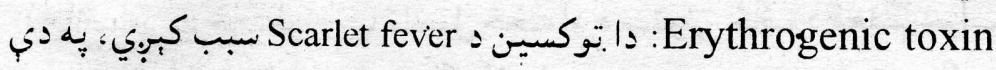

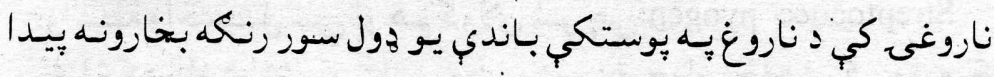
كَبِّي. كيري Streptolysin-O يـ : Haemolysin كبربِي. تورته Seukocidin Toxin Streptolysin :Febrinolysin Riboneuclase او De oxyriboneuclease .Protienease ,Amylase

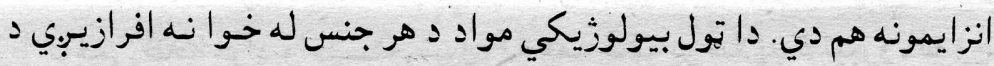

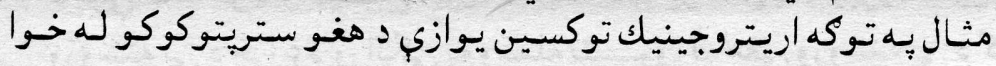

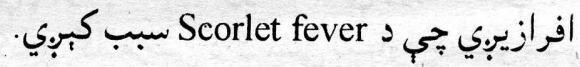

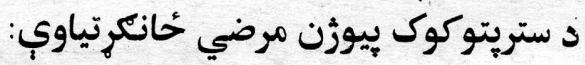

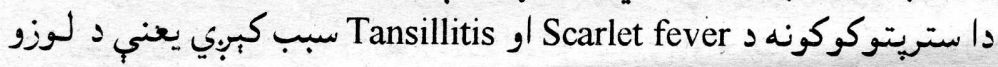

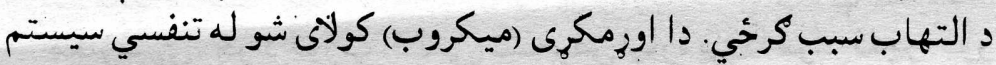

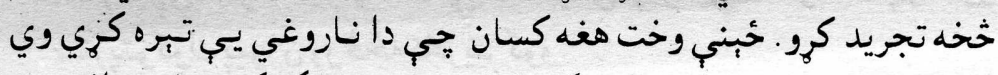

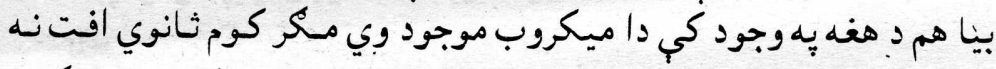

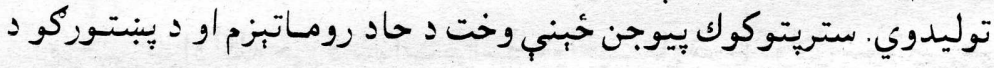
التهاب سبب هم كبريجي. د ستريتوكوك ييوزن إيبديمولوزي:

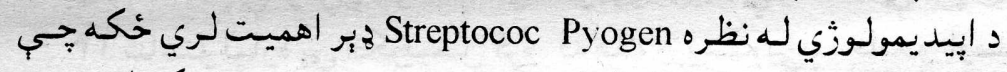

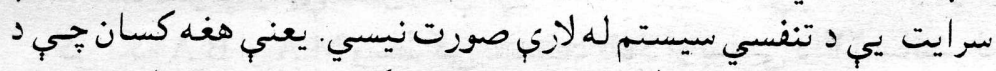

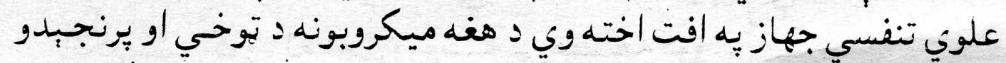

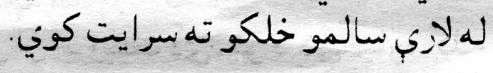

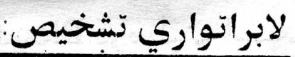




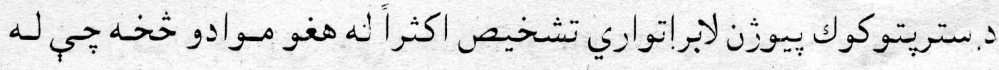

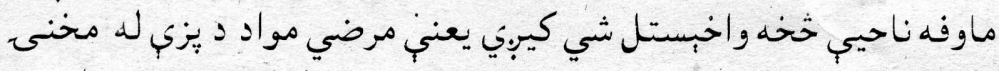

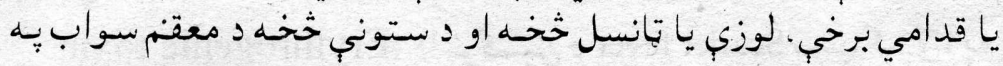

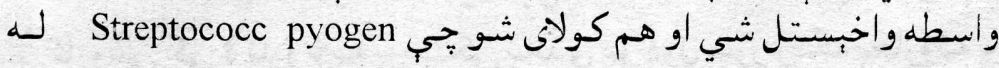

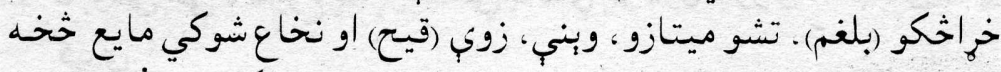

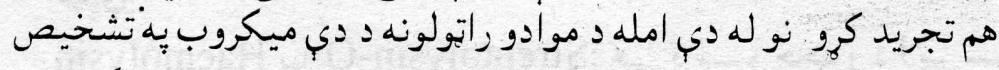

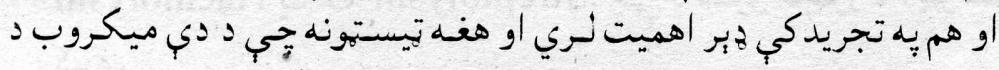

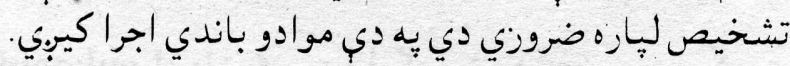
مستقيمه ميكروسكوييكه معاينه:

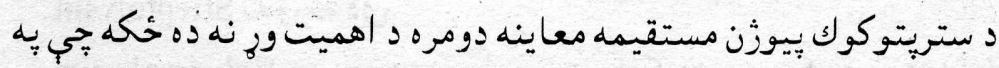

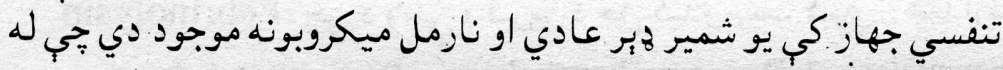
Strep.pyo.

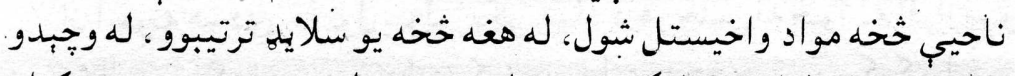

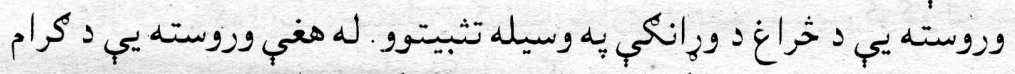

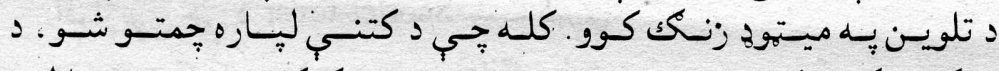

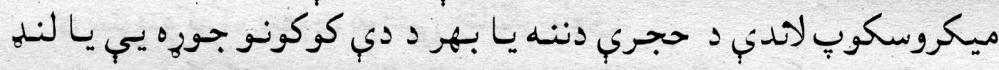

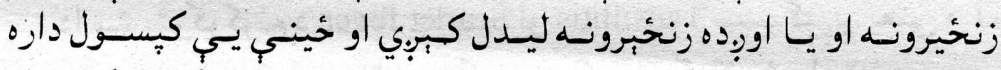

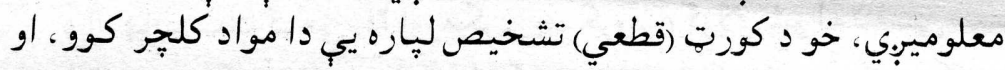

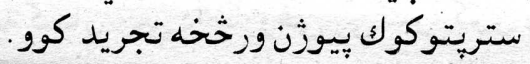
كلهر:

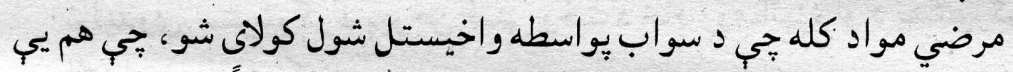

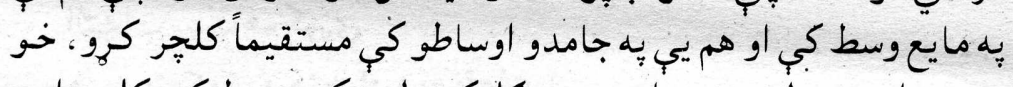

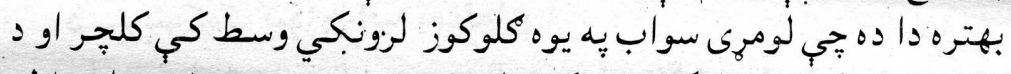

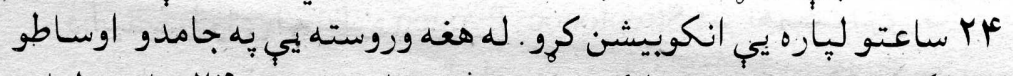

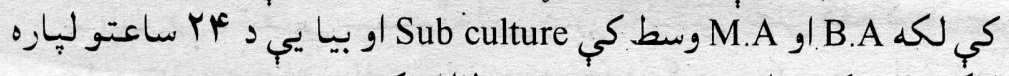

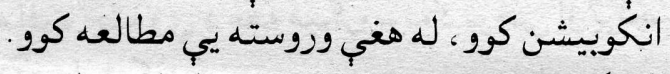

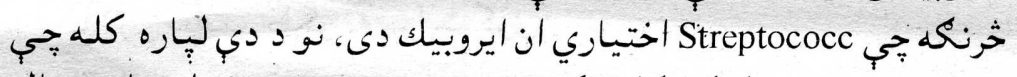

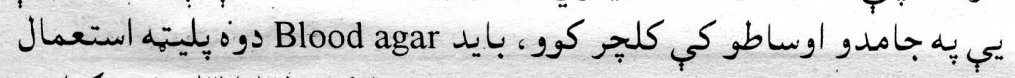

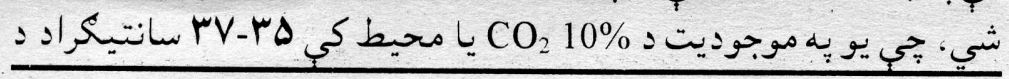




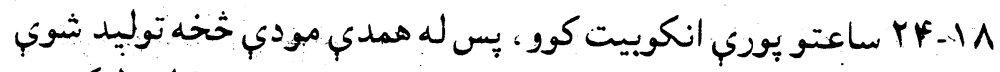

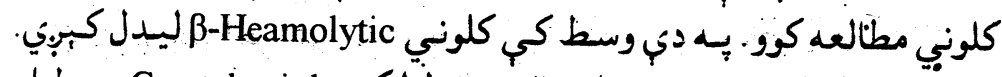

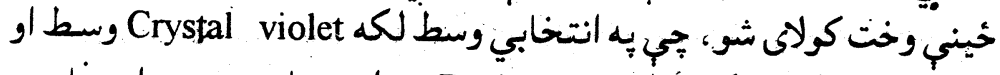

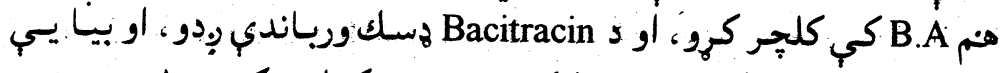

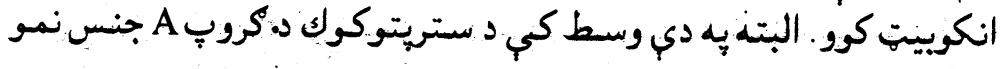

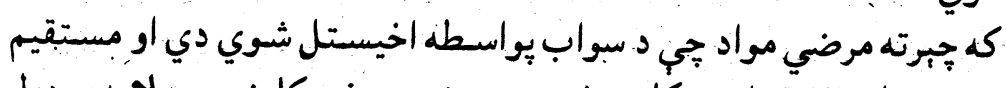

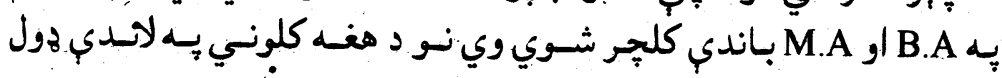
مطالعه كوو.

Blood Agar Aerobic

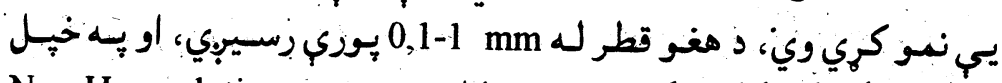

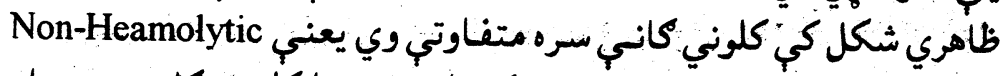
او ماهري

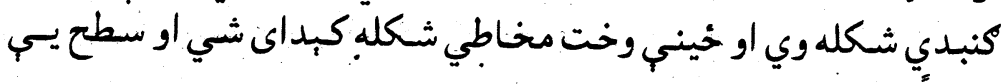
تقريباً رنه وي.

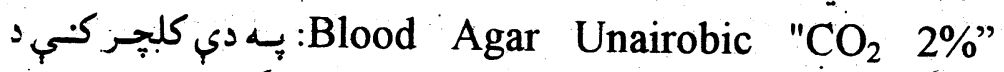

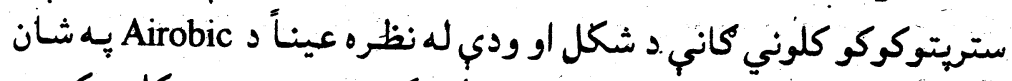

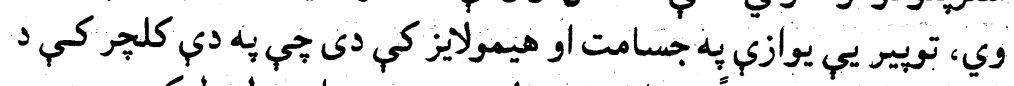

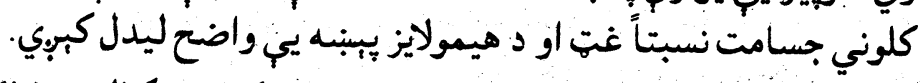
(Ficalis) د سترييتوكوك فيكاليس :Macckanky Agar Bile Salt

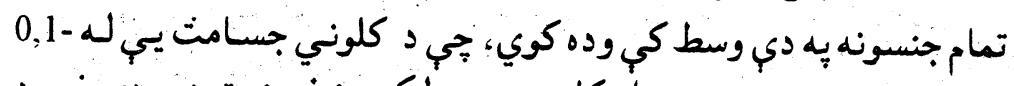

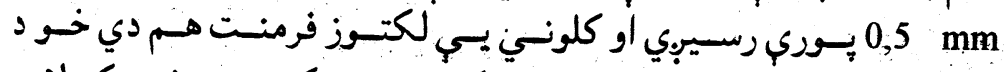

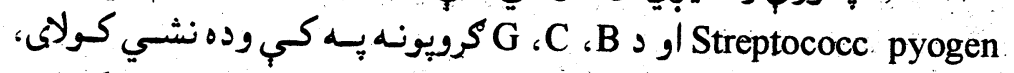

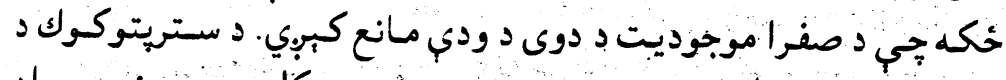

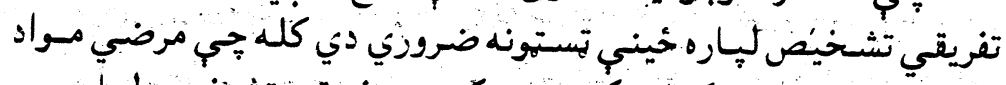

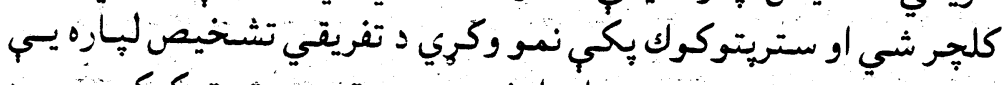

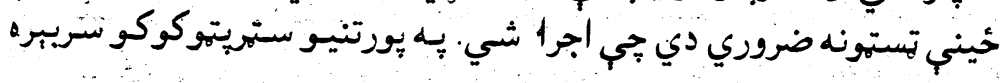




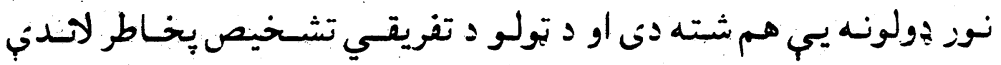
تستبونه بايد اجرا شي.

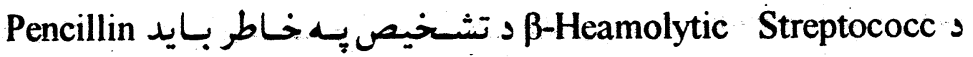

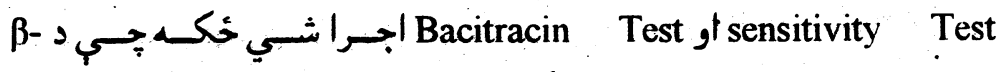
Heamolytic Group-A

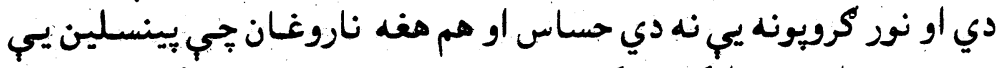

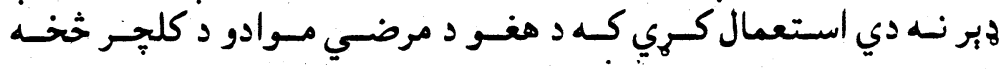
Streptococc B.Heamolytic

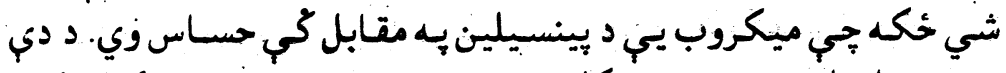

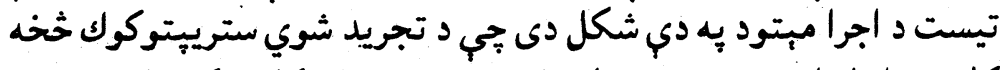

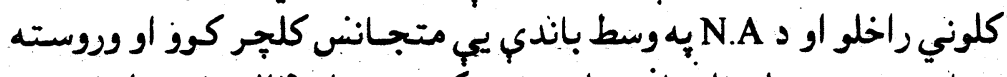

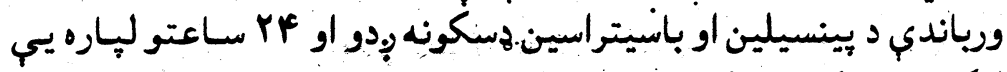

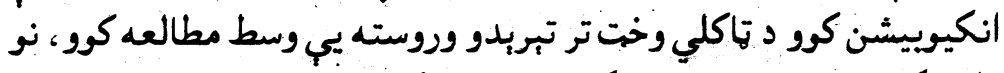

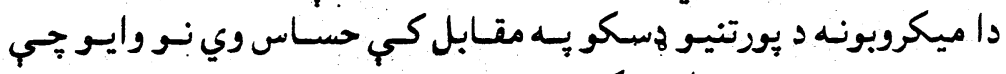

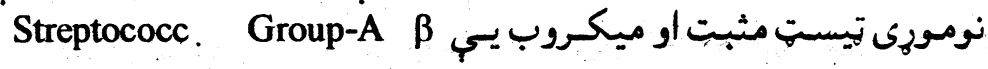
Heamolytic

ه- Heamolytic streptococcus

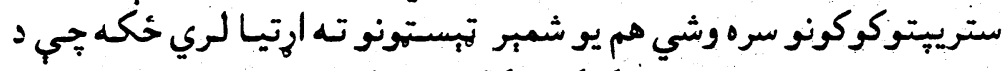

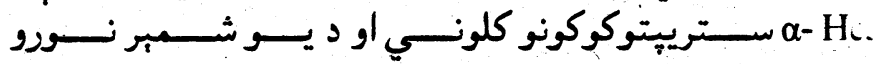

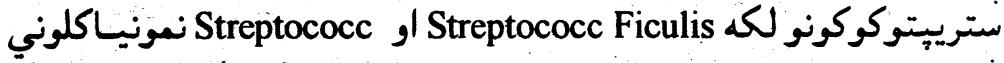

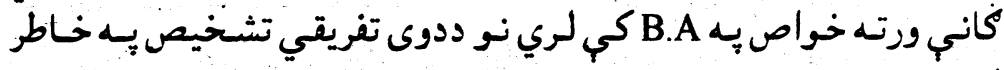

1- Bile solibilty test.

2- Bacitracin test

5- Macckanky bile salt agar

$$
\text { لاجدي تيستونه ضروري دئ }
$$

3- Heat Resistance test

4- Asculin test

Streptococc Non Heamolytic airobic

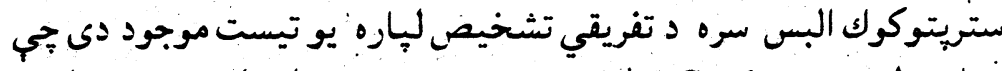

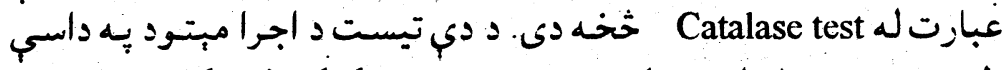

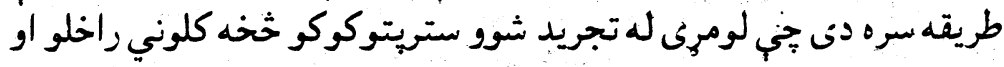

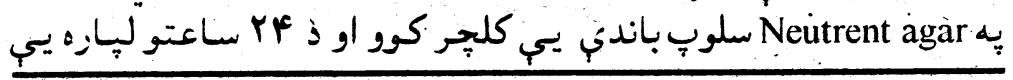




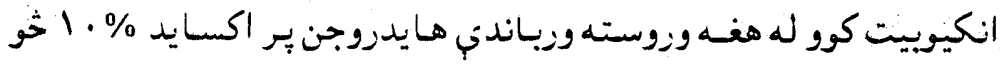

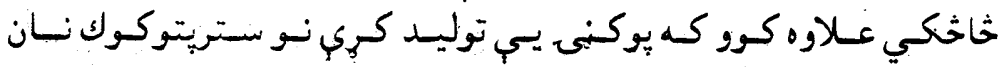

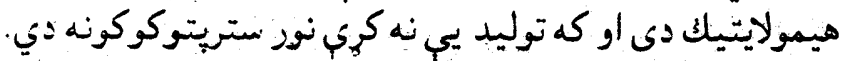
اكيجان Streptococcus-Non Heamolytic unairobic

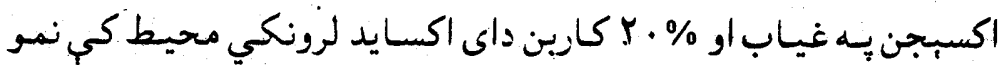

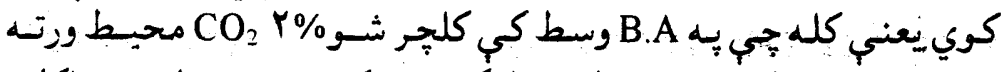

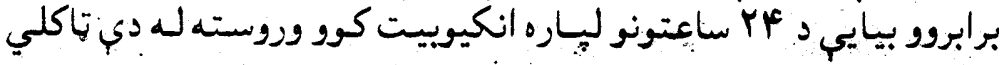

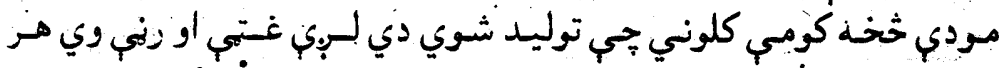

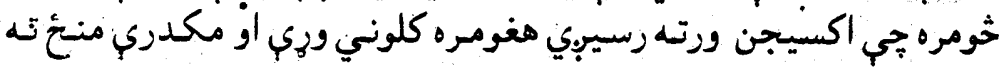
راحي.

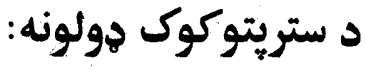

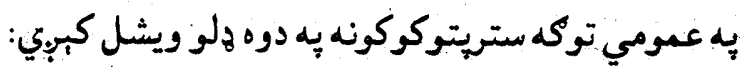
Streptococc pyogen يا Streptococcus Heamolytic: I

Streptococcus non Heamolytic: $r$ Ds lance field داسـه Sterptococcus Ficalis.a

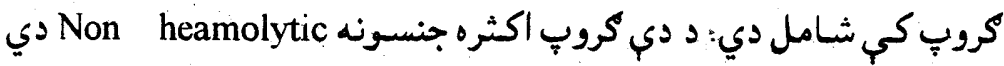

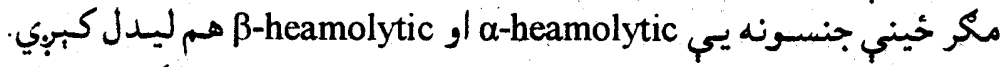

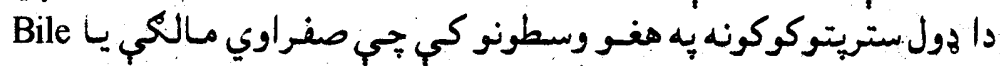

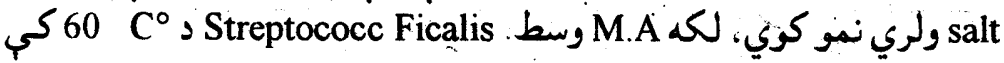

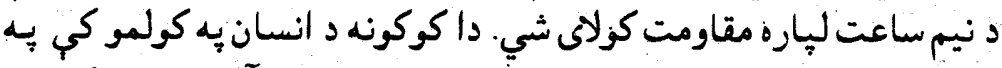

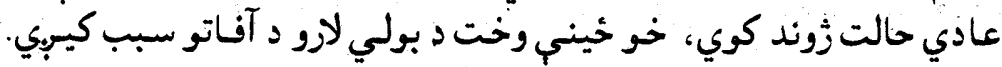

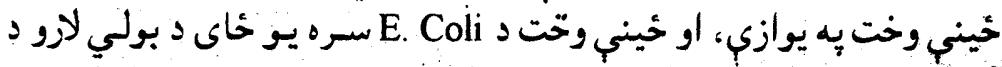

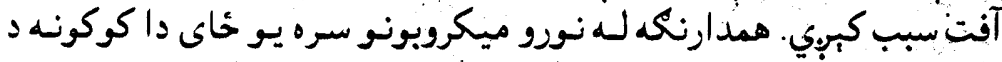

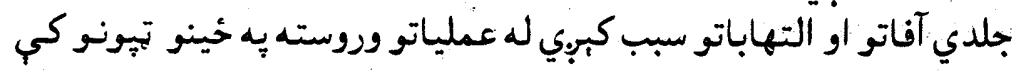
هم يِيدا كبربي. Streptococc Veridancc.

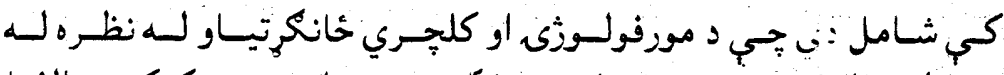

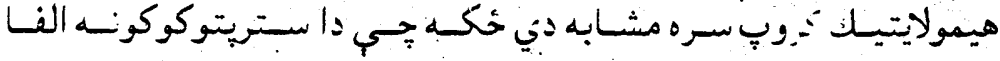




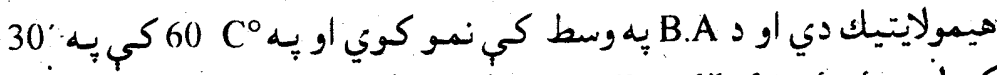

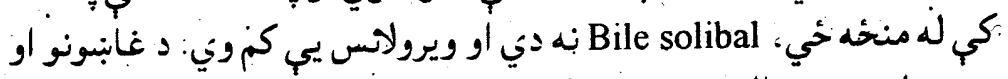

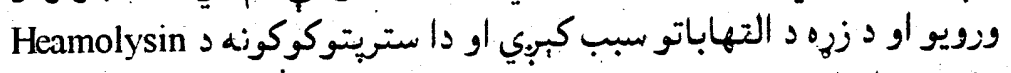
كئ toxin

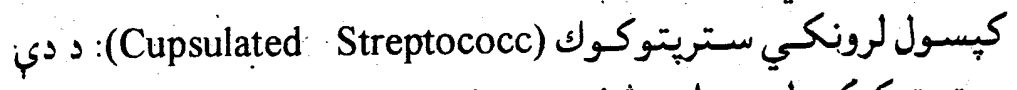

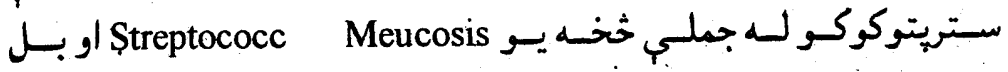
Streptococc aronson

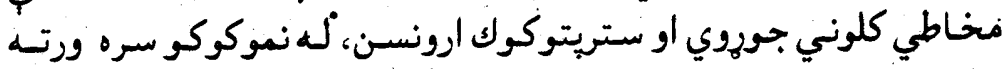

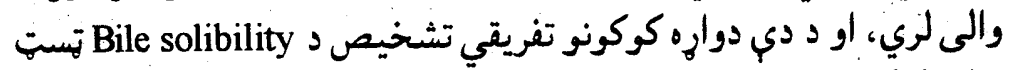
يواسطه كيبري.

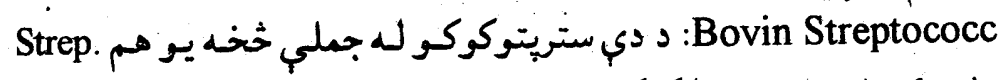
Agalactic

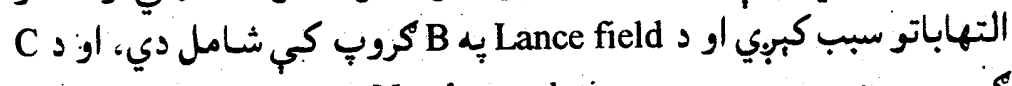

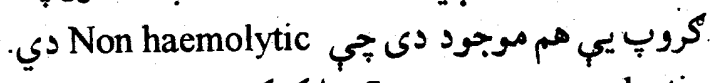

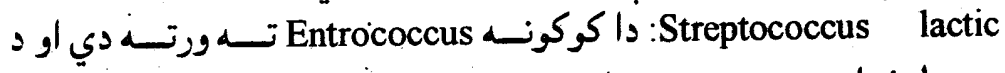

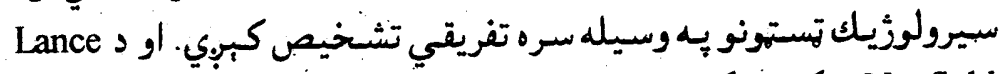
N د field Streptococcus Non haemolytic

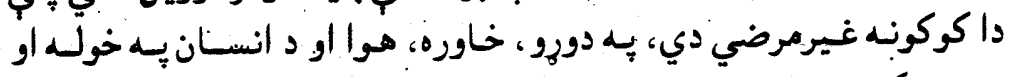

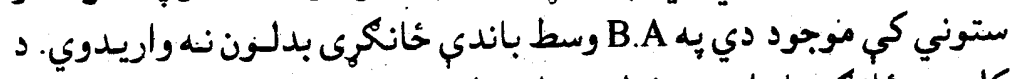

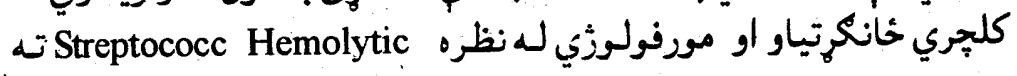
ورته دي. 


\section{نموكوكونه (Pneumococcus)}

مورفولوزي:

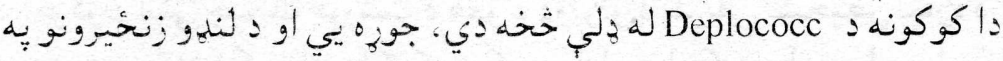

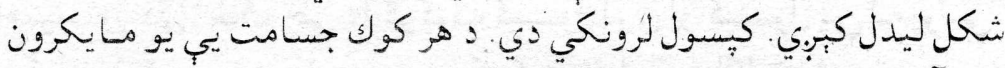

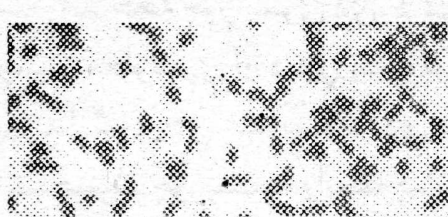

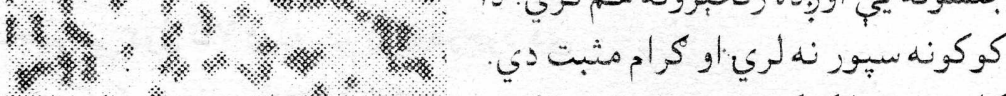

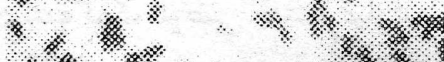

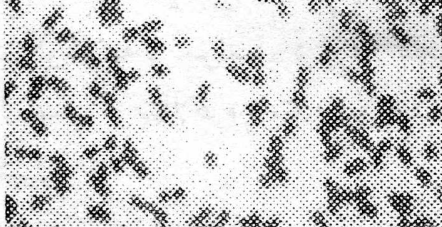

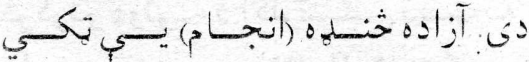

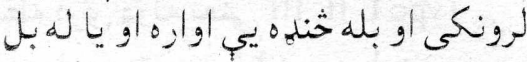

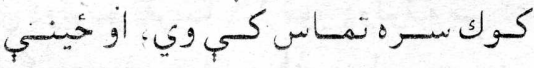

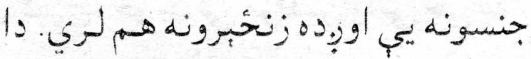

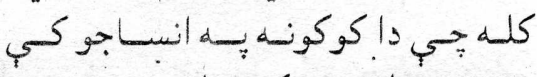

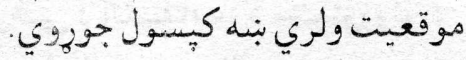

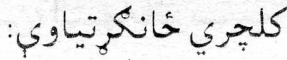

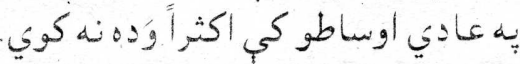

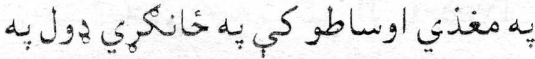

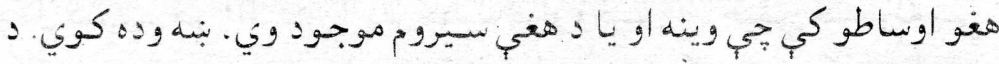

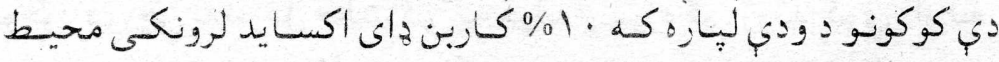

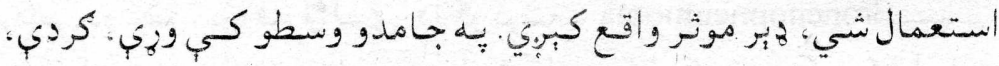

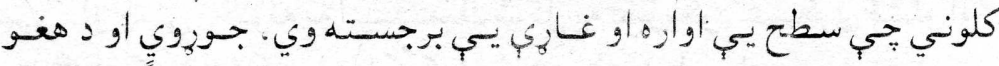

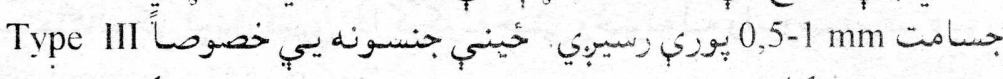

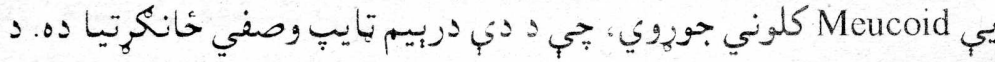

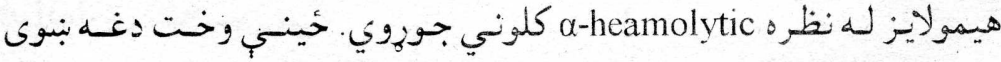

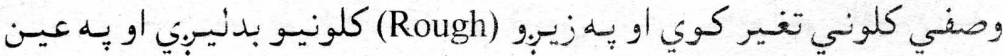

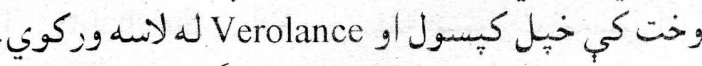

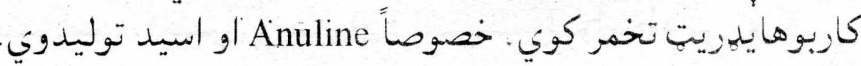

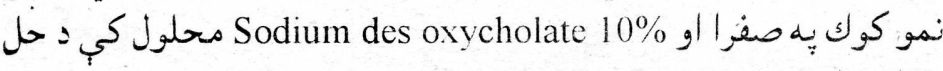

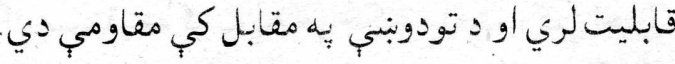


د نموكوكي انتي جينيكن جوربنت:

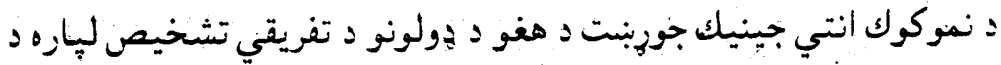

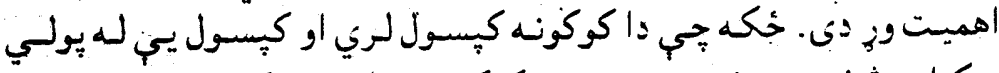

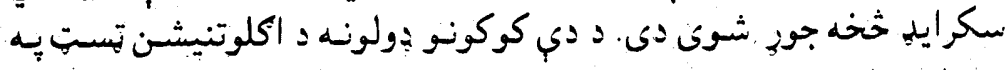

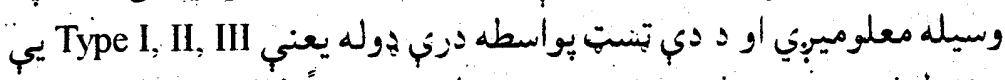

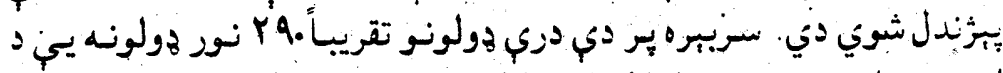

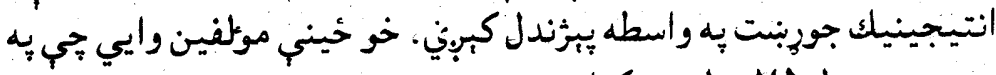

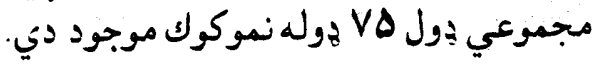

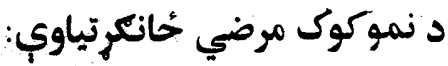

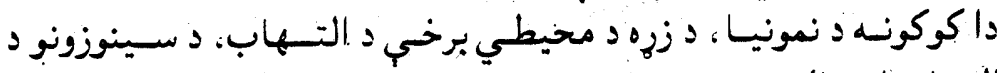

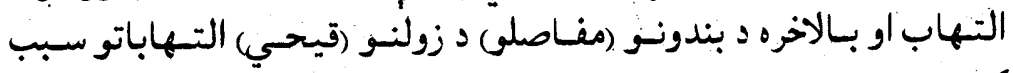
كبوي.

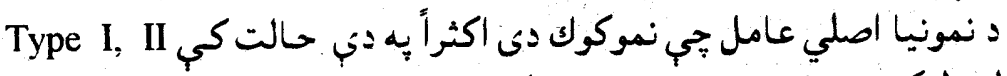

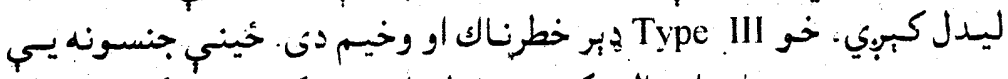

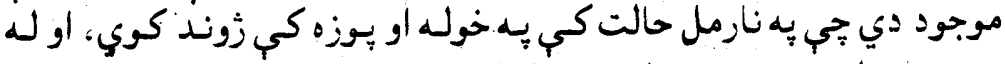

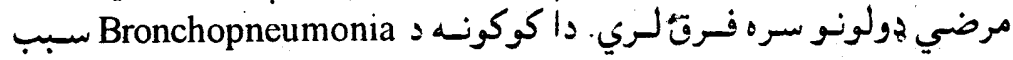

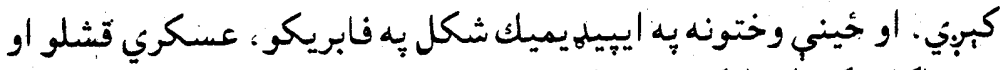

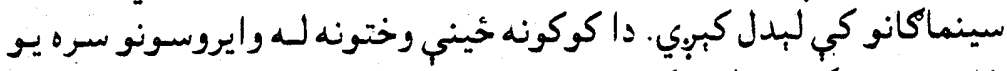

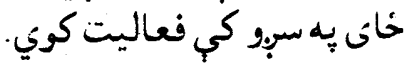

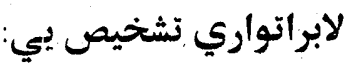

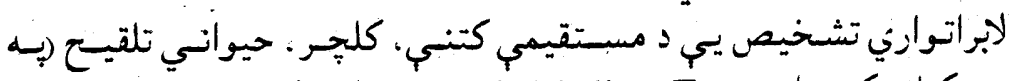

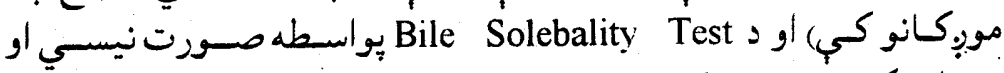

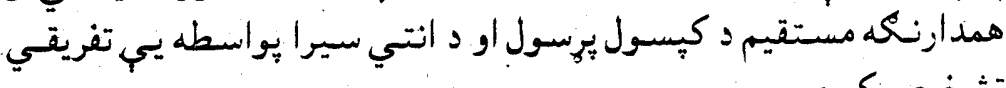
تشخيص كبري.

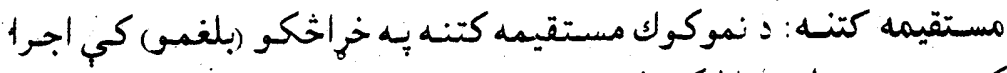

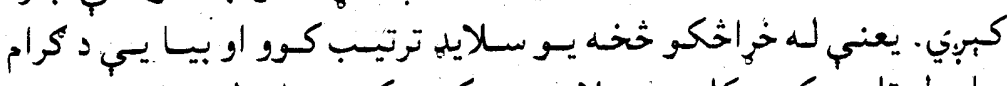

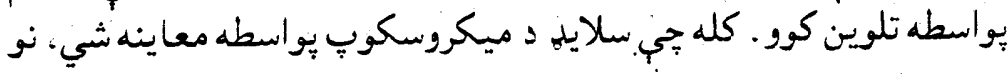




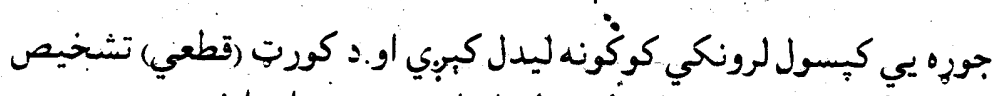

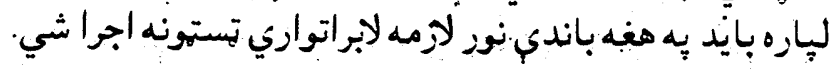

:

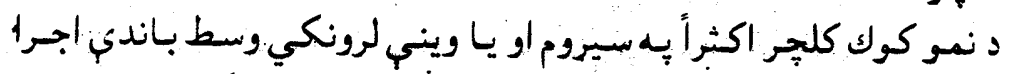

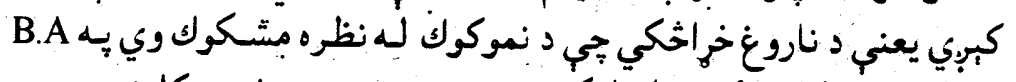

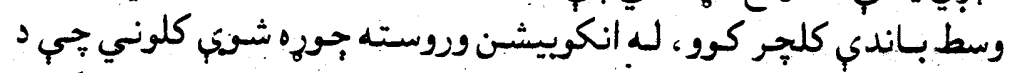

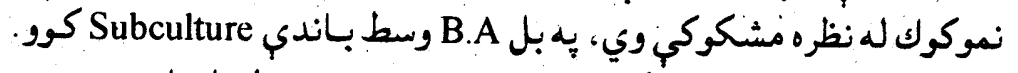

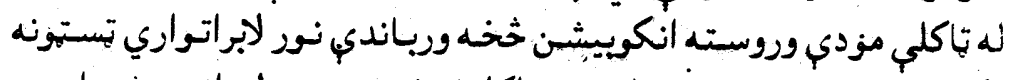

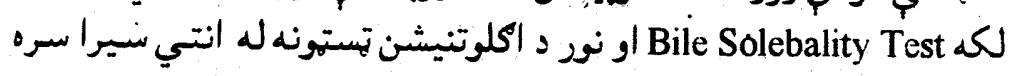
ورباندئ اجراكوو. نارمل :Bile.Solebality Test

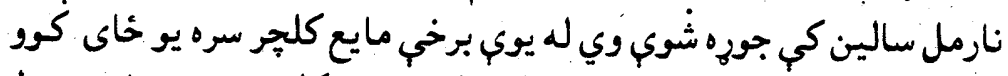

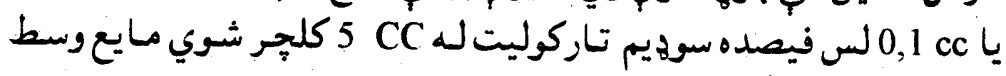

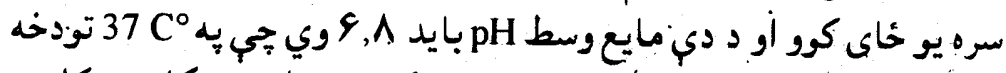

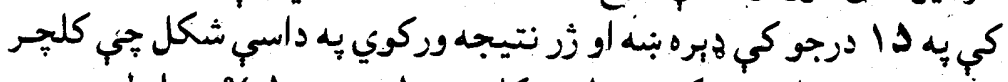

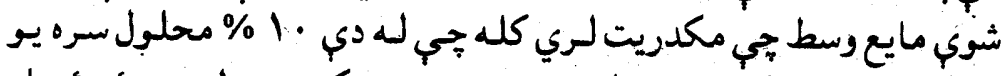

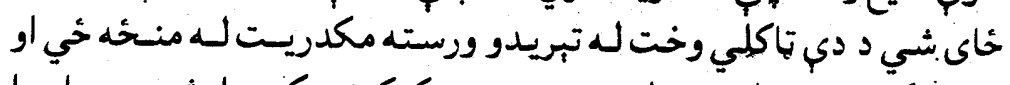

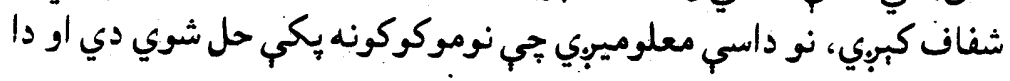

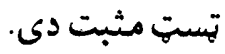

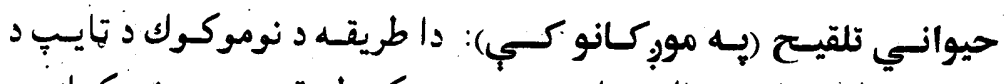

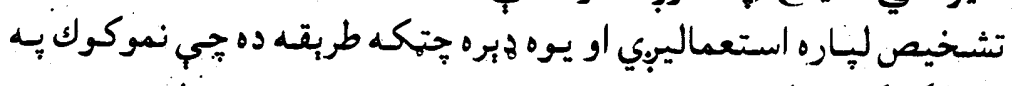
خ خاخكو كي معلوموي.

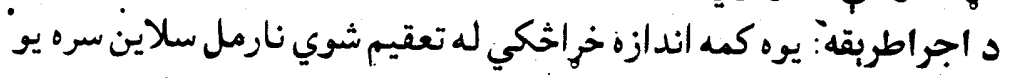

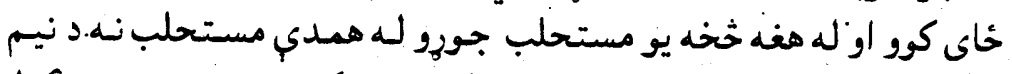

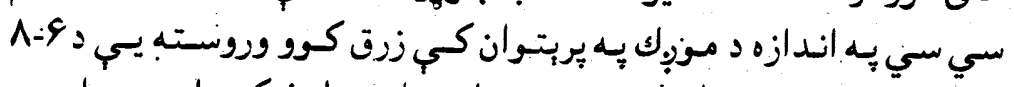

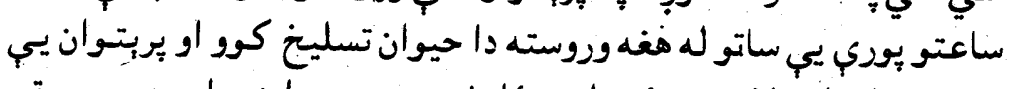

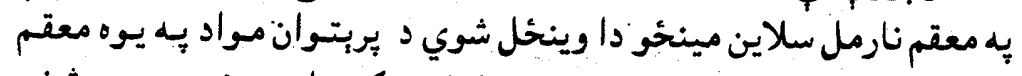

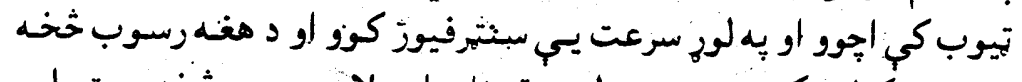

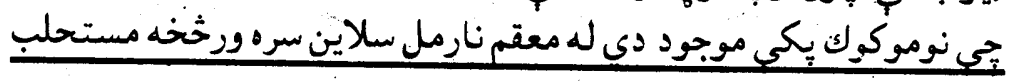




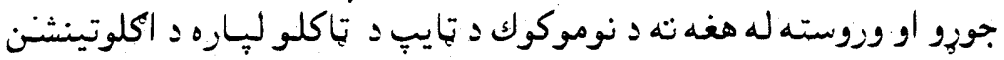

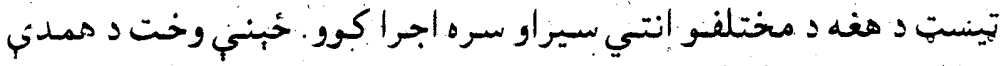

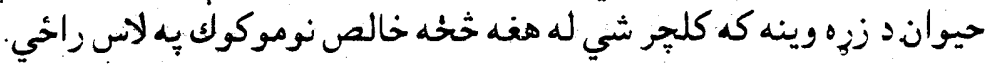

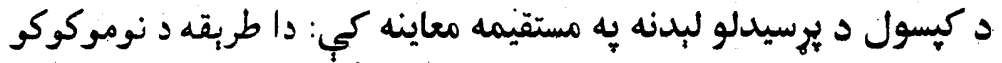

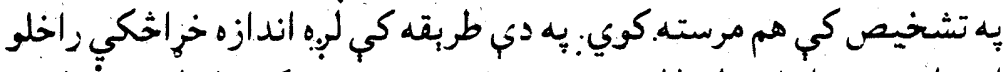

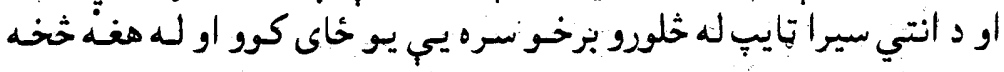

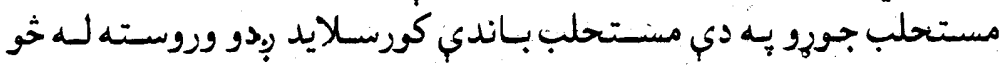

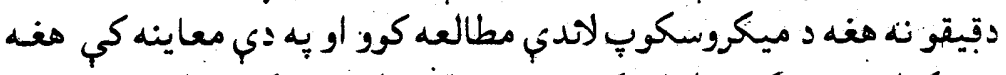

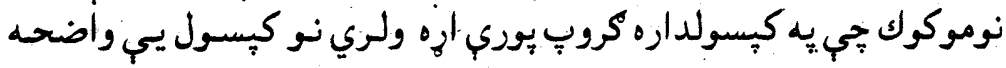

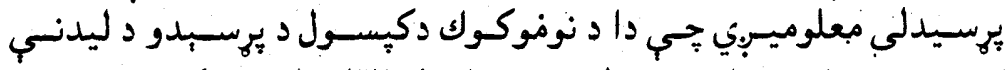

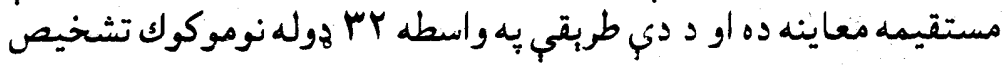

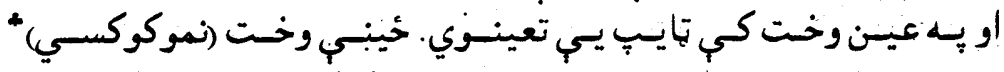

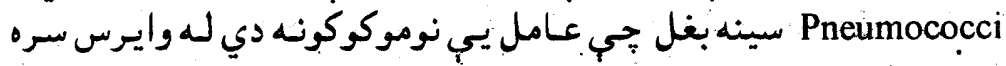

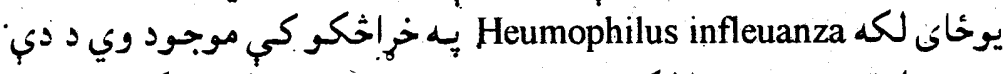

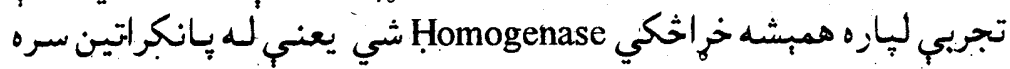

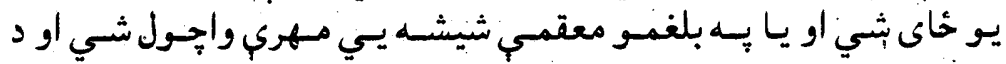

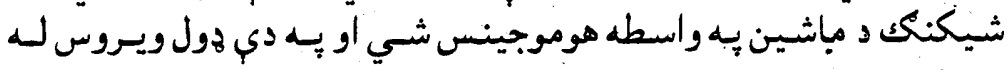

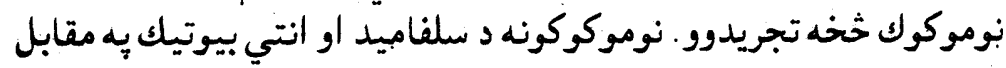

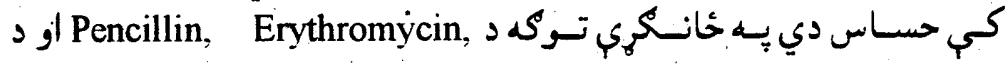
Tetracyclin

Pneumococci *

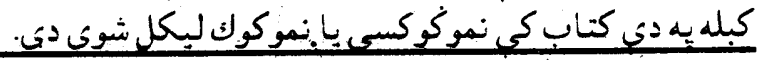




\section{د نايسيريا كروب (NEISSERIA GROUP)}

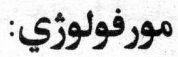

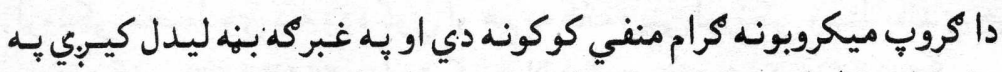

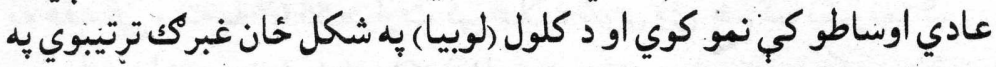

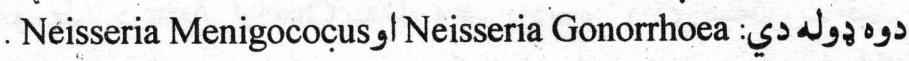
Gonococcus

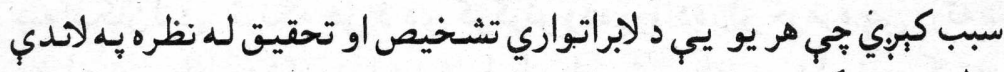
هول توضيح كوو:

نايسريا كونوريا (Niesseria Gonorrhoea)

\section{د نايسريا د كروب مورفولوزي او تلوين:}

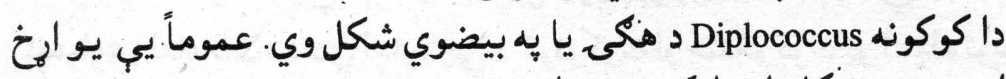

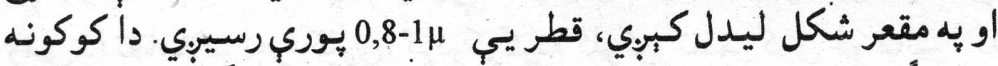

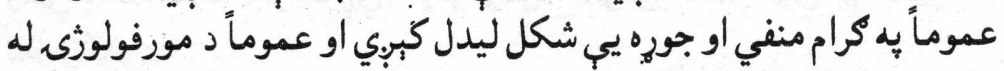

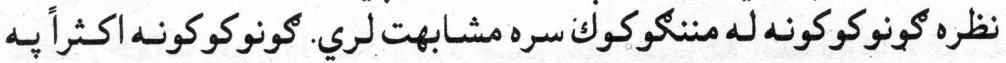

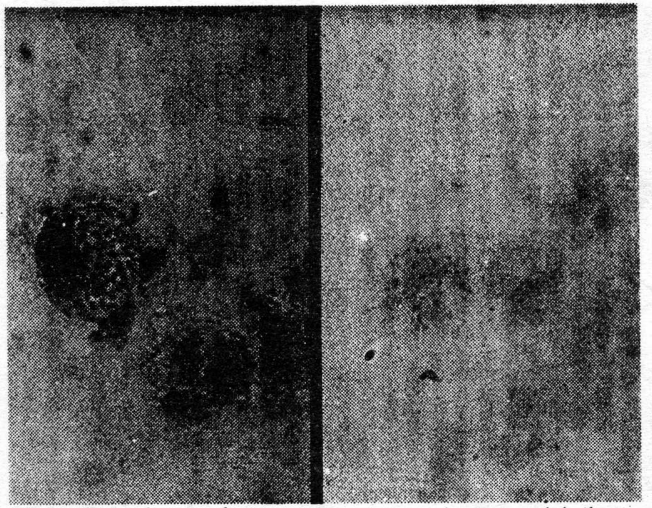

داهليلي ويسجارج نمونه جسي Polymorphonuclear

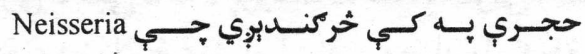
Gonorrhoea

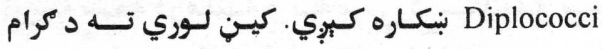
تلوين او بني أرخ ته د Sandiford تلوين.

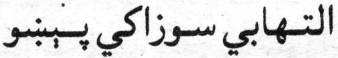
كي ليدل كبوبِي او د هنيه

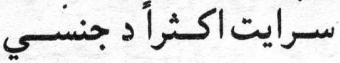
مقاربت يه وسسيله منـح ته

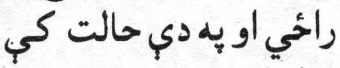

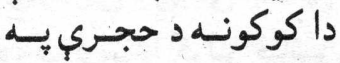

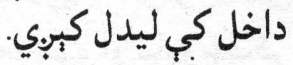

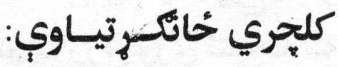

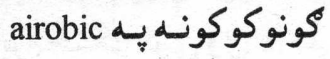
شكل نشوو نما كوي اويه وده 38-39C وده تغيرمومي خو عموماً.

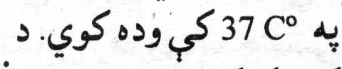
كونوكوكــــو د ودي يـــــنه 


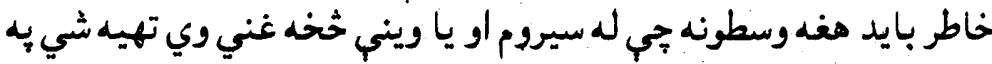

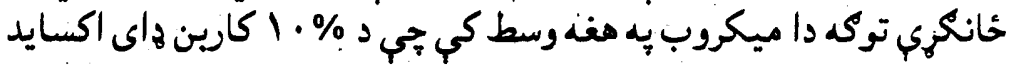

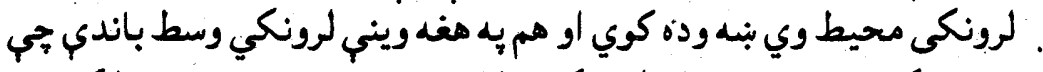

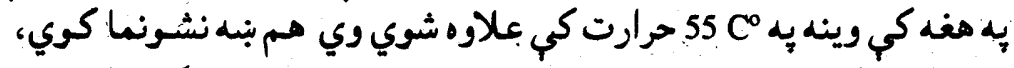

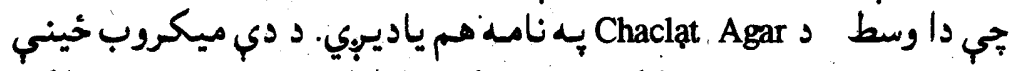

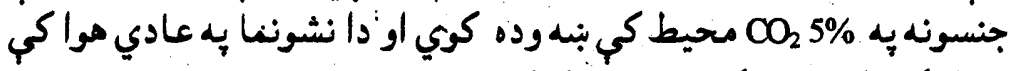

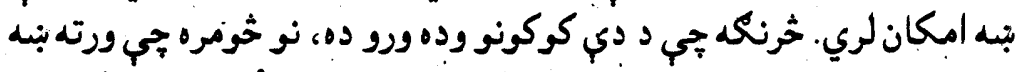

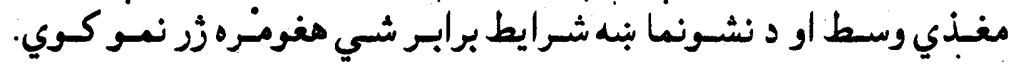

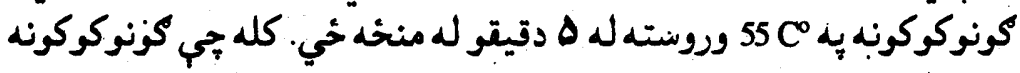

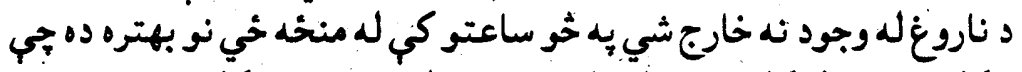

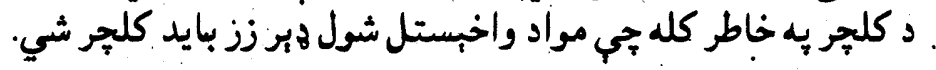

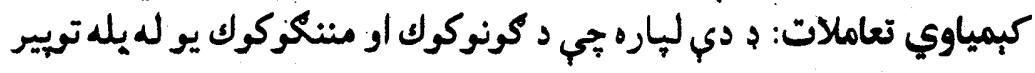

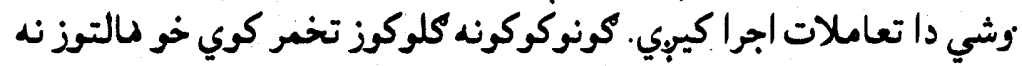
تخمر كوي.

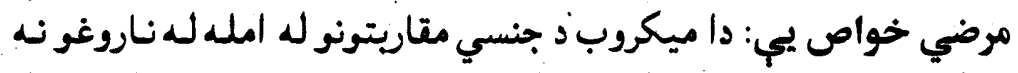

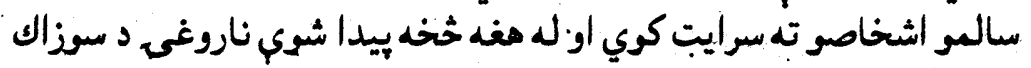

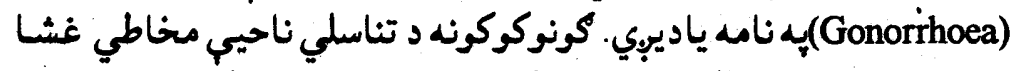

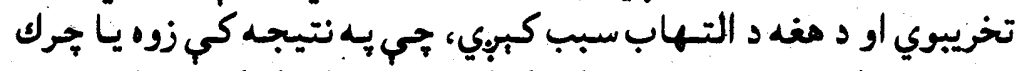

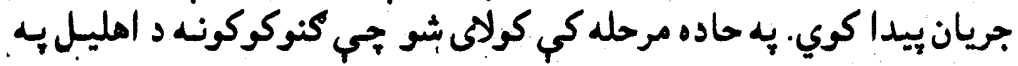

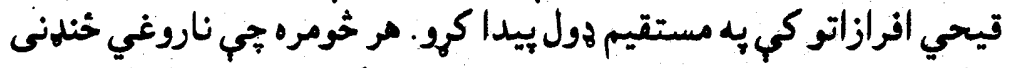

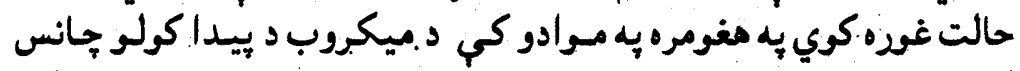

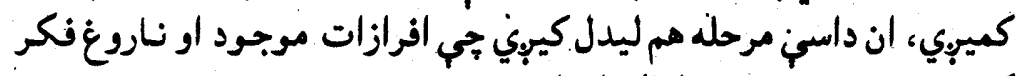

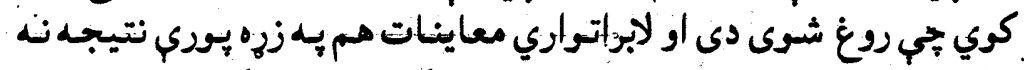

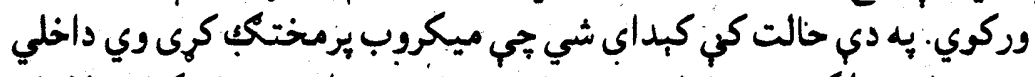

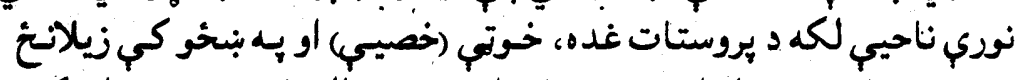

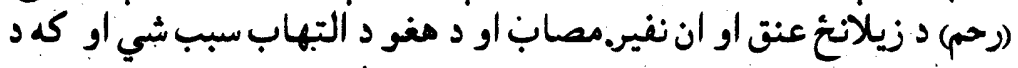

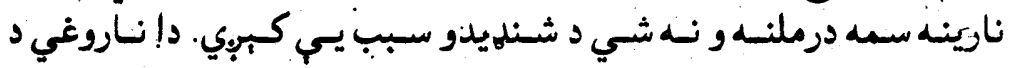

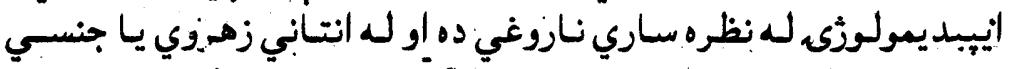
ناروغيو خخه دهويد 


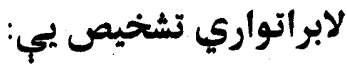

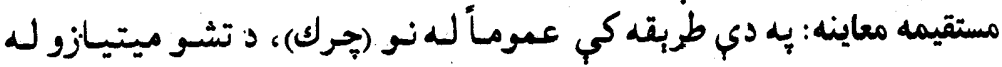

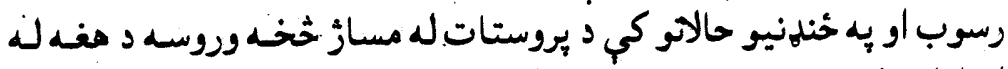

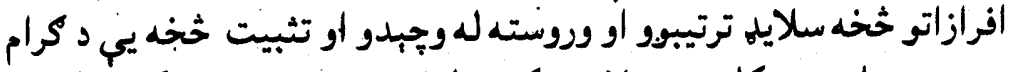

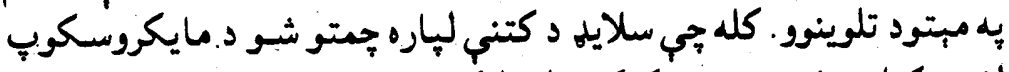

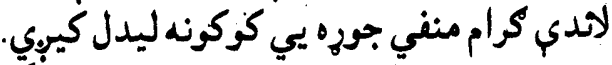

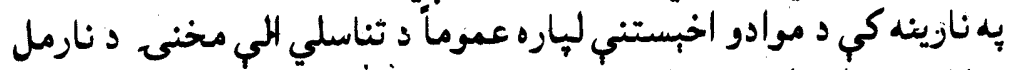

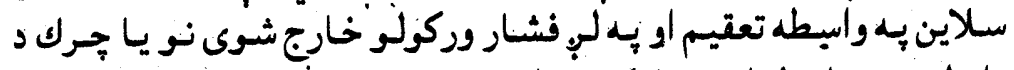

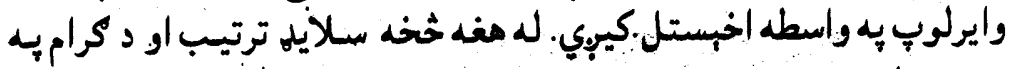

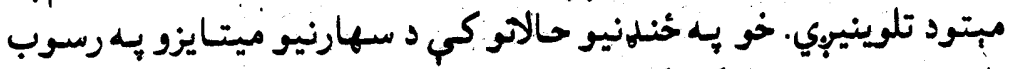

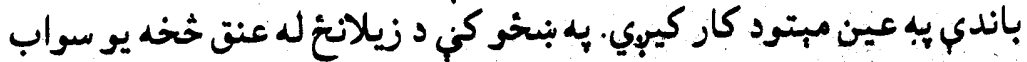

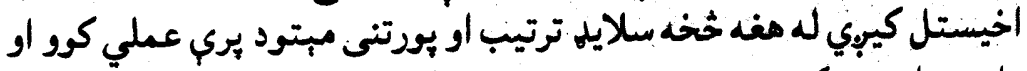

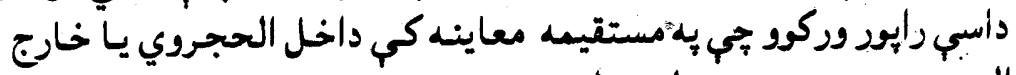
(In direct

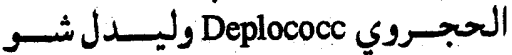
examination intra or extra cellolar Depolococc seen. د كونوكوك كلجر:

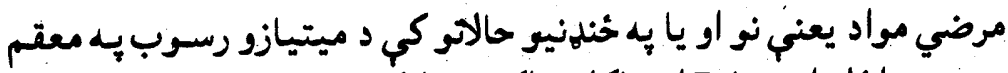

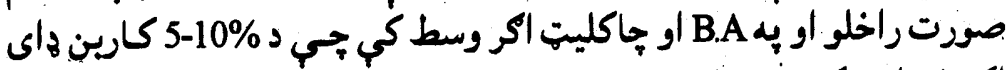

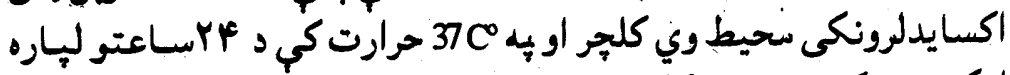

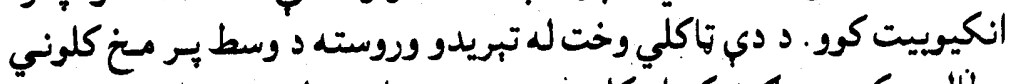

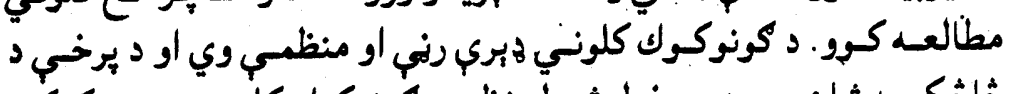

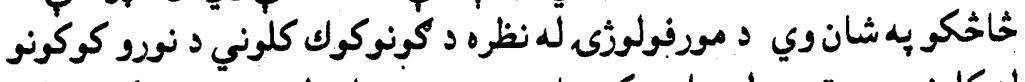

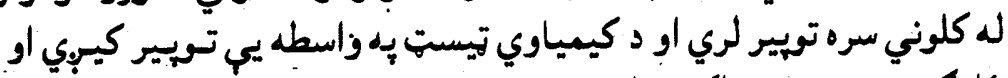

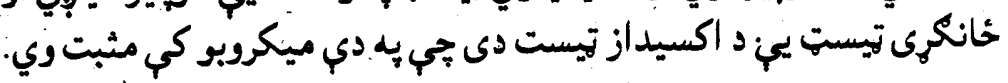

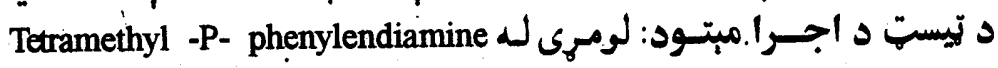
hydrochloride

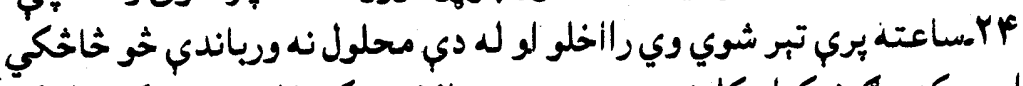

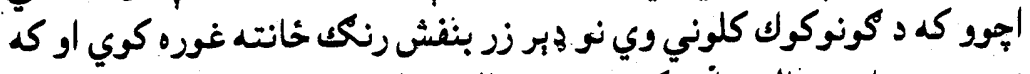

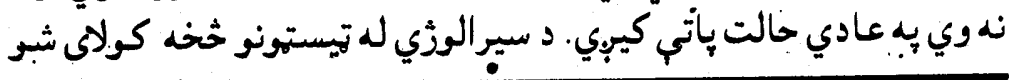




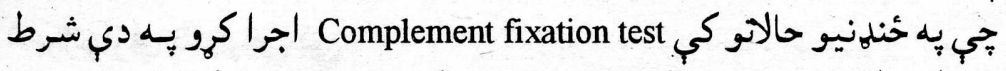

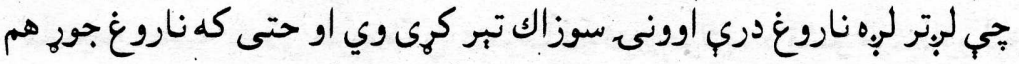
شي تر دري مياشتو بوري دا تيست مثبت كبداي هم شي.

\section{مننكوكوكونه (Meningococcus)}

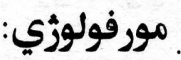

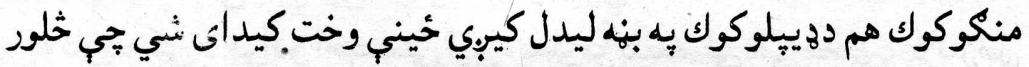

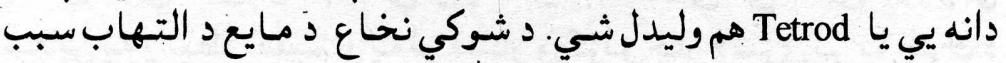

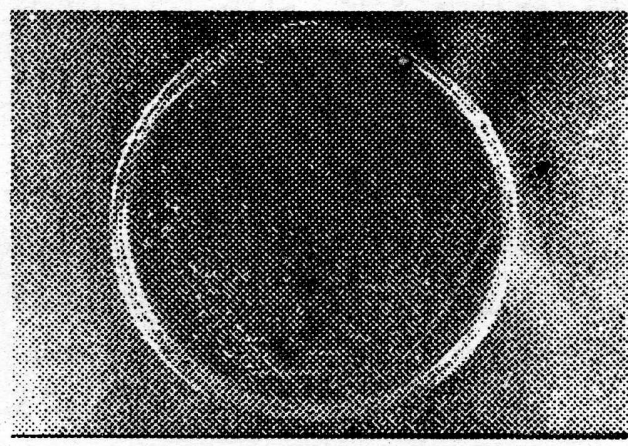

Nesseria Meningitidis بـ بـ بـاكليت اكر كسي د Oxidase test

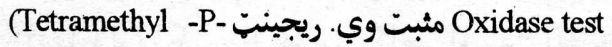
phenylendiamine hydrochloride) خبريري او د نايسيريا كلوني هلابي رنت غوره كوي.

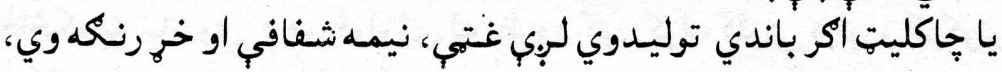

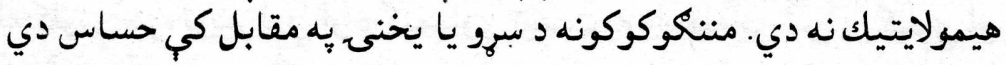

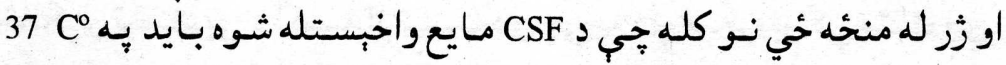

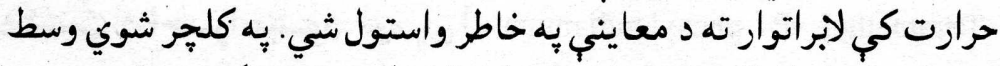

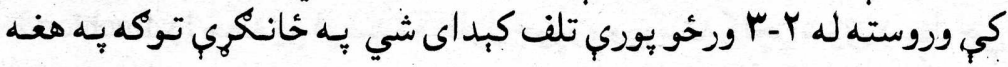

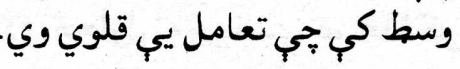

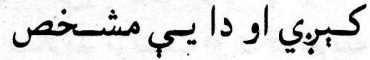
وصف دى ك. كرام منفي دي مئي

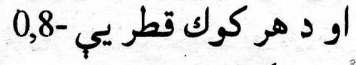
1 كلجــري خـواص يسـي:

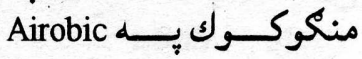
شكل نشونما كوي او كهـ شم شي هم نمو كوي د نشونما

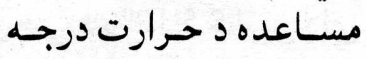

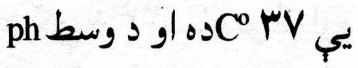
يب بايدد 7,4-7 وي. كومي وني

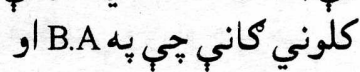




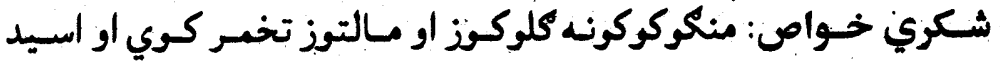

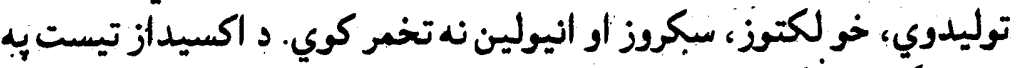
دي، ميكروبونو كي منفي دئ

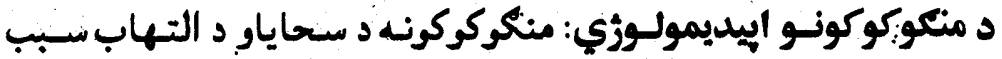

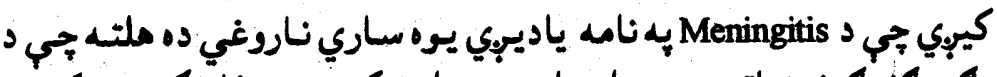

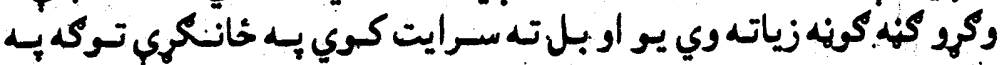

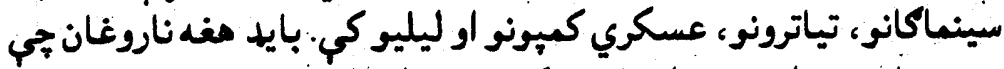

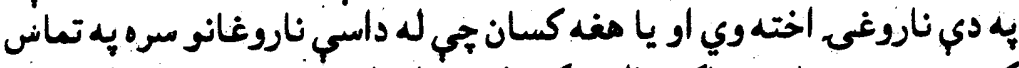

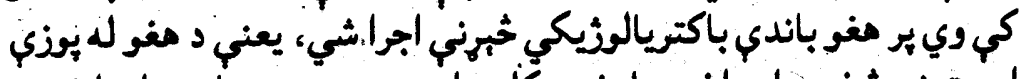

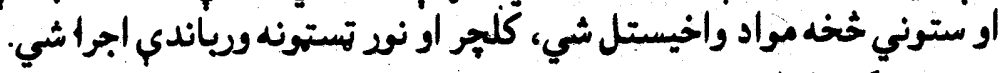

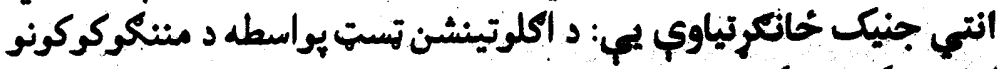

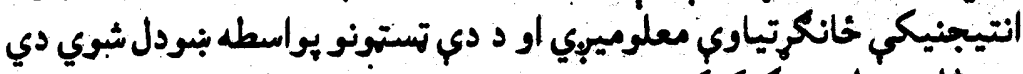

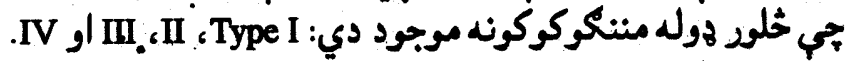

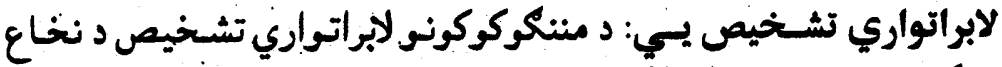

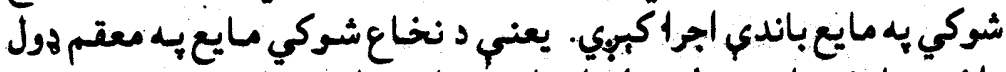

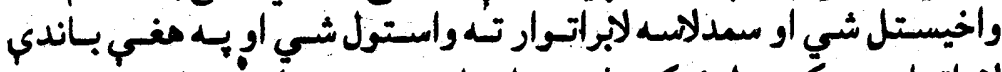

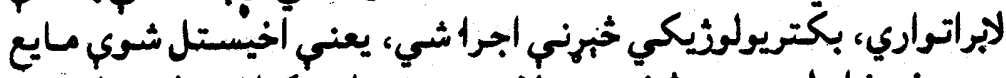

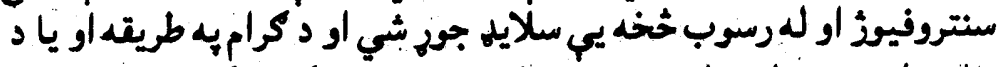

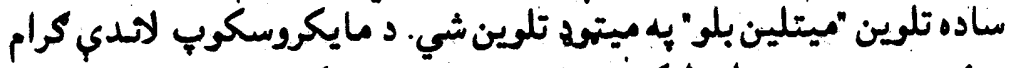

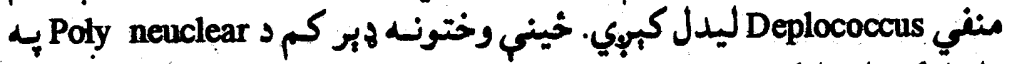
داخل كي ليدل كبوي.

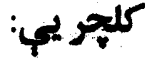

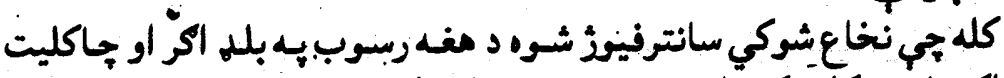

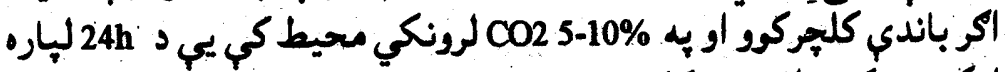

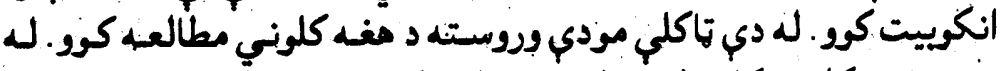

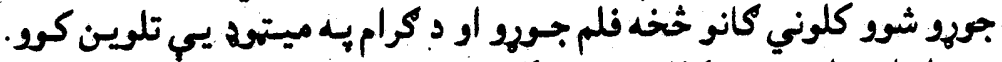

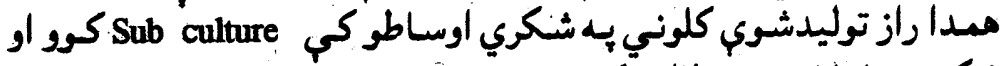

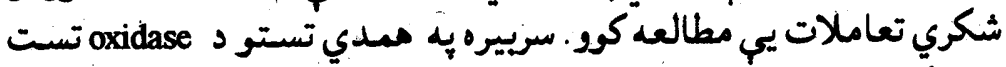
مم يري اجراكور. 
حيني وخت مننككوكونه د انتيبيوتيك يه مقابل كي حسابس او د حساسيت

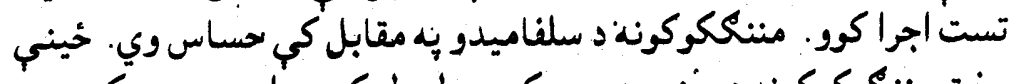

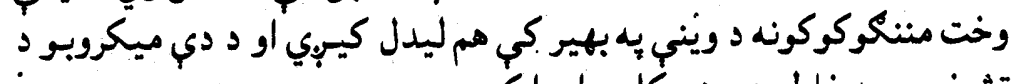
تشخيص به خاطر د ويني كلجز اجرا كيبئي.

\section{د ايسريا دكروب نور دولونه}

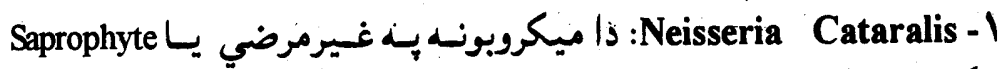

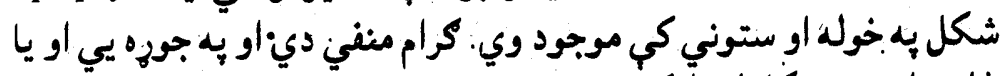

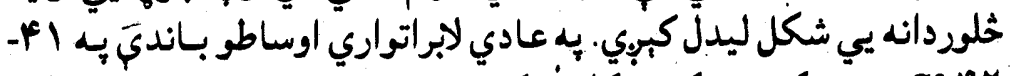

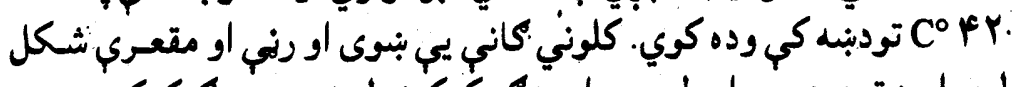

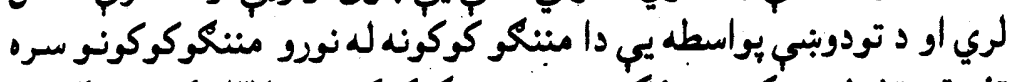

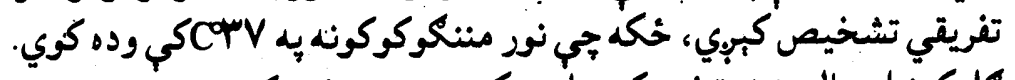

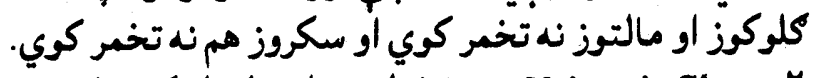

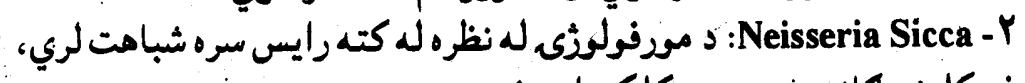

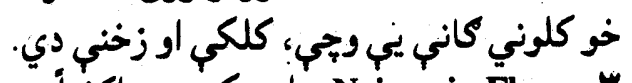

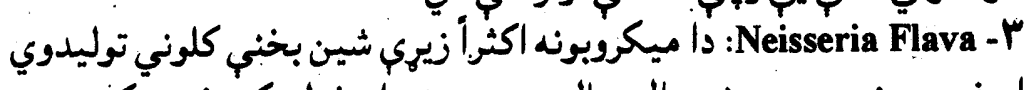

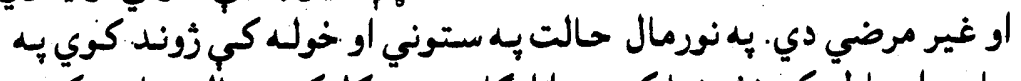

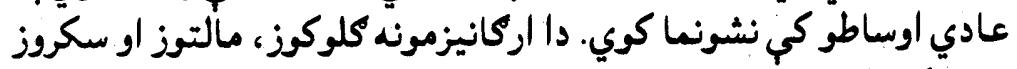

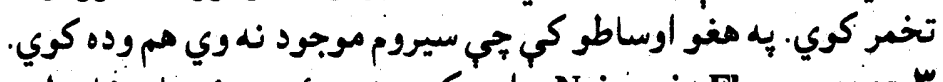

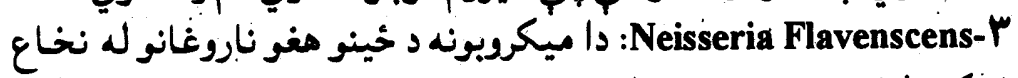

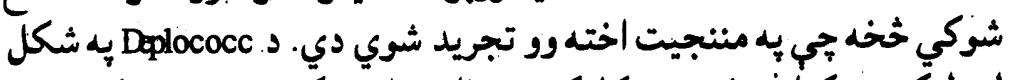

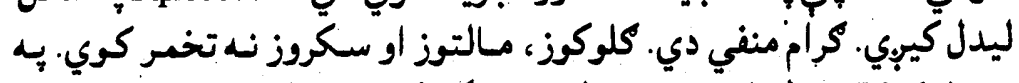
Blod Agar

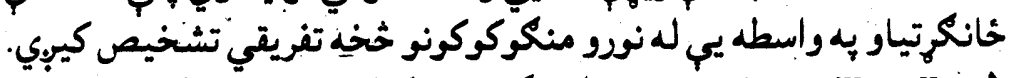
ته

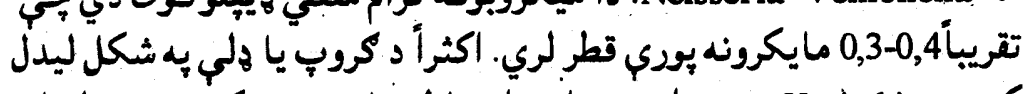

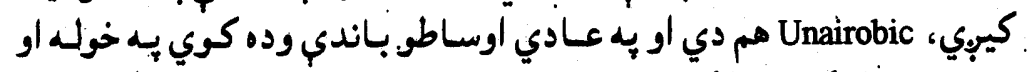
هضمي جهاز كي ييدا كيبري. 


\section{كرام مثبت باسيلونه (Gram Positive Bacilli)}

\section{د ديفتري باسيلونه دiphtheria bacillus}

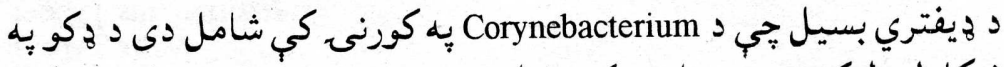

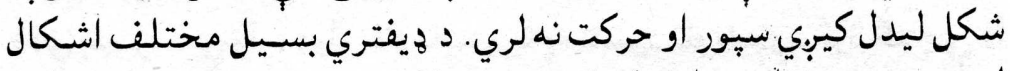

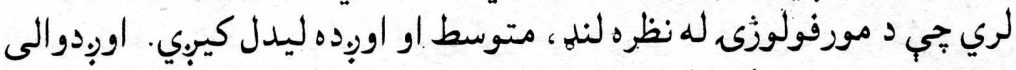

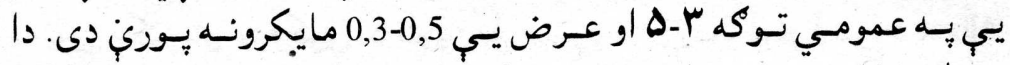

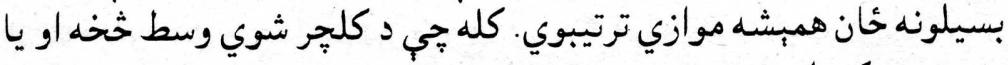

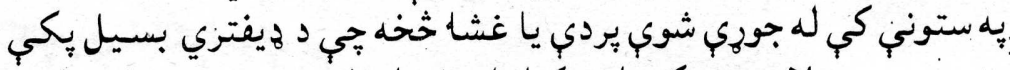

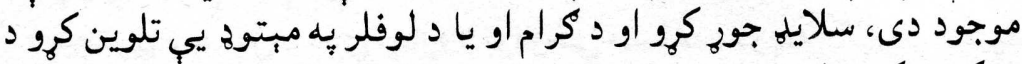

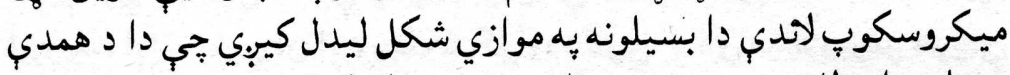

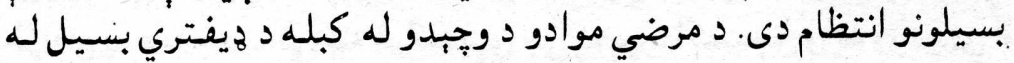

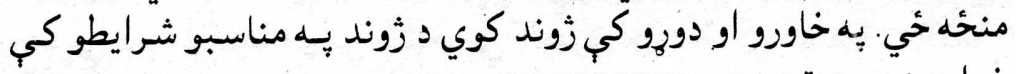

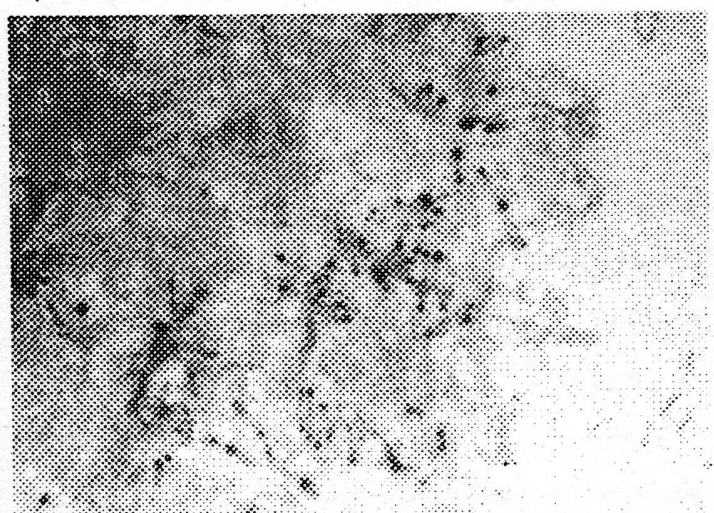

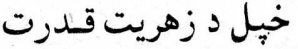

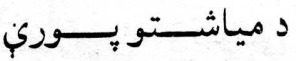

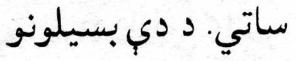

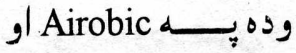
Unairobic صسورت نيسي او يس لفه

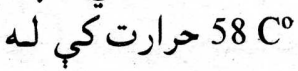
منحئه حئ حري. د د ديفتري ذ بسيل

دلنه Corynebacterium diphtheriae د نسارونو او مقعـرو

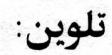

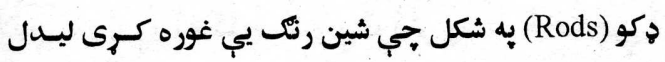
كيري. د د Albert تلوين.

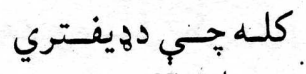
بسيلـLeffler

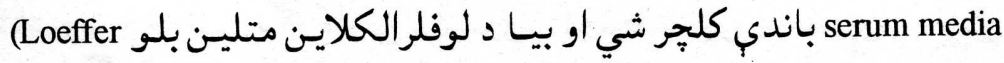
جيه alkline methylin blue)

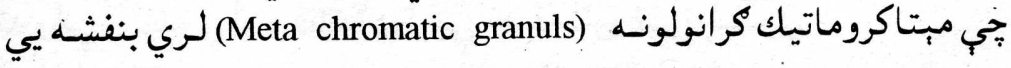


رنكك غوره كوي، خو جسم يي خفيف روبنانه رنك اخلي. به عمومي توكى و. هيفتري دري خوله بسيلونه شتهن: Gravis Type-1 Intermedius Type-2 Mitis Type-3

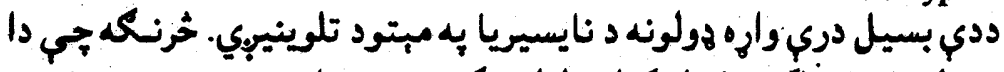

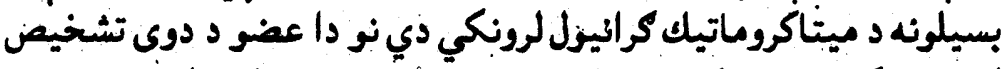

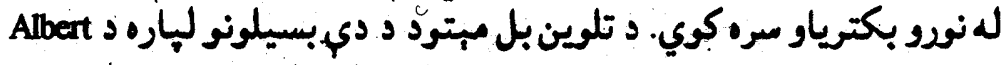

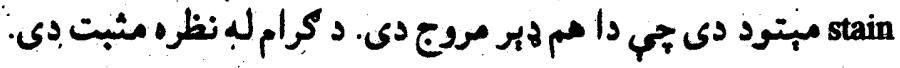

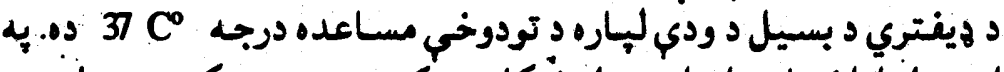

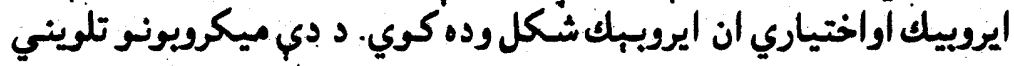

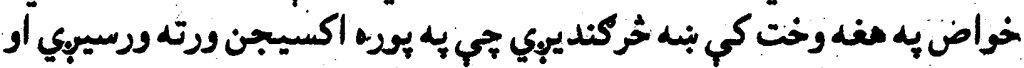

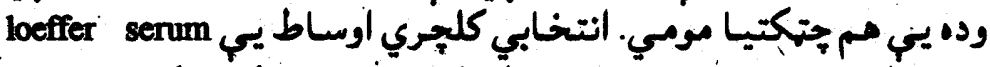

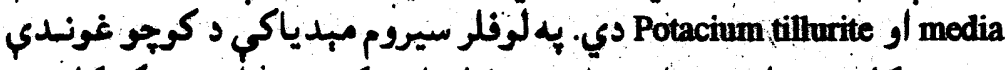

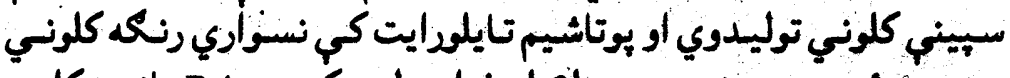

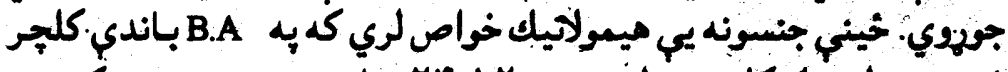

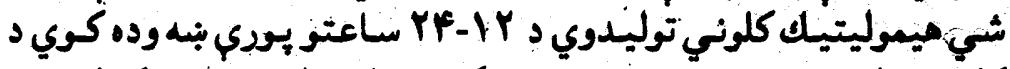

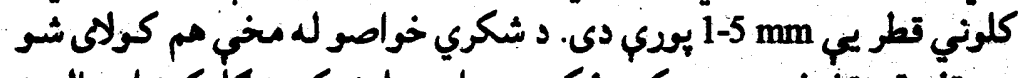

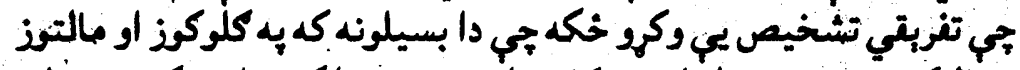

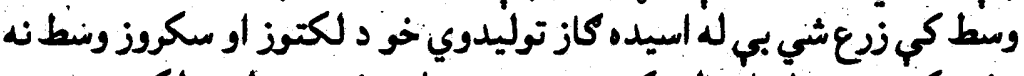

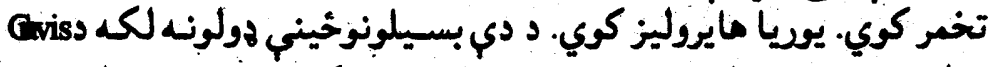

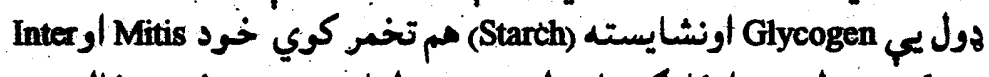
medeus

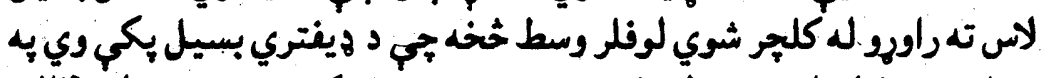

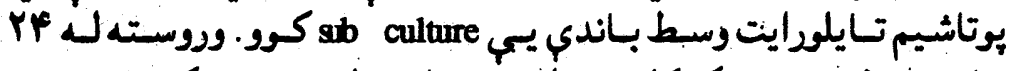

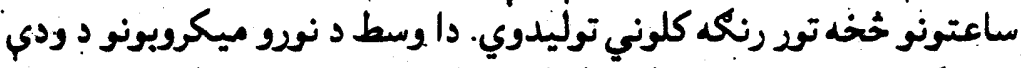

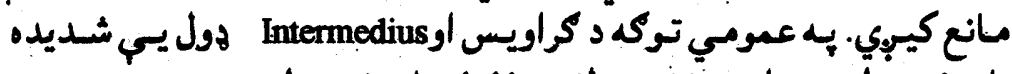

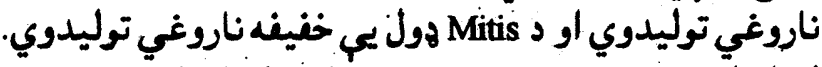

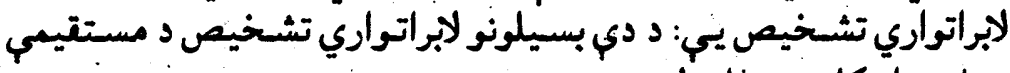
معايني اول كلجر به واسطه صورت نيسي. 


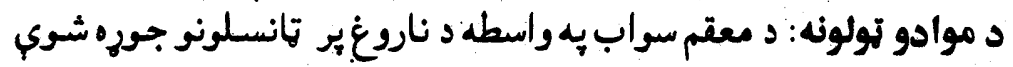

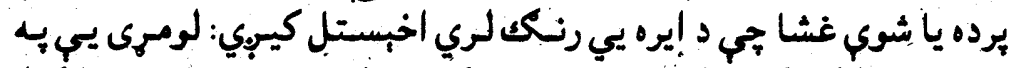

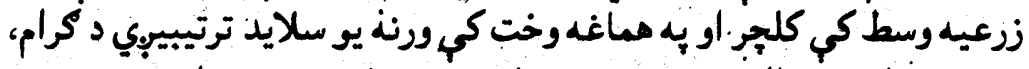

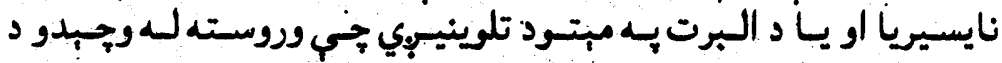

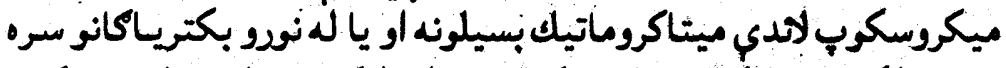

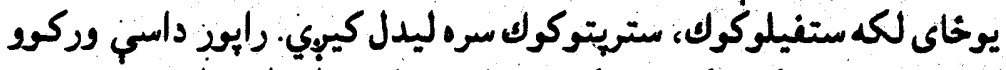

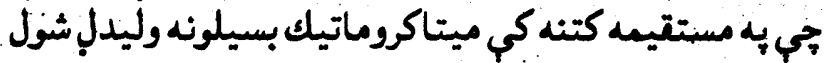

(In direct exam Metachromatic bacilli seen)

كلجر شوي اوساط لكه B.A, Leoffler او يوتاشيم تيلودايت يه انكيو بيـتر

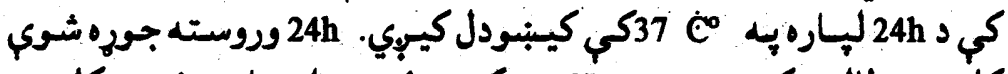

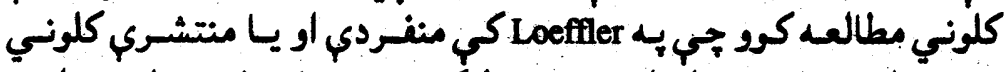

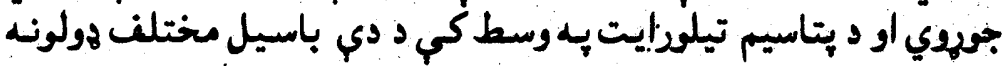

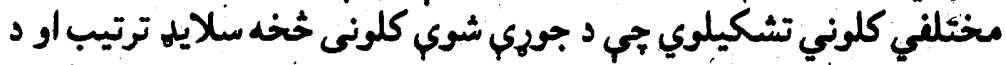

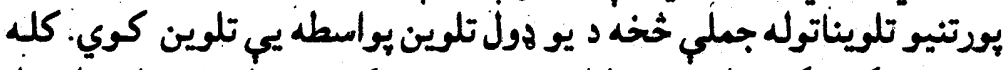

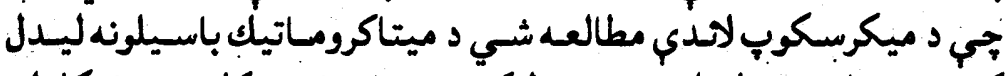

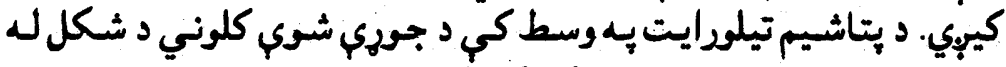

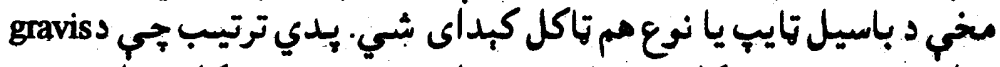

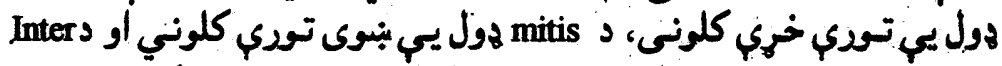

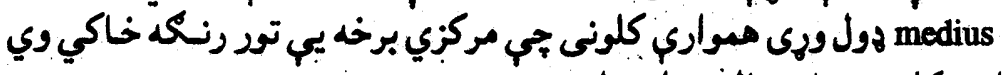

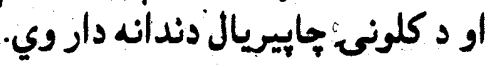

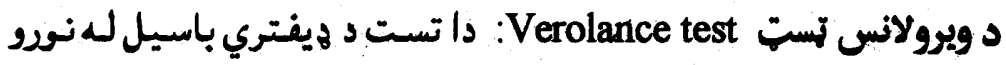

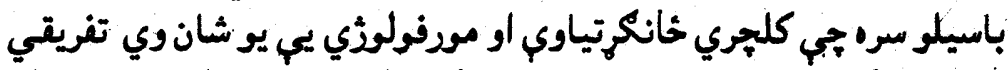

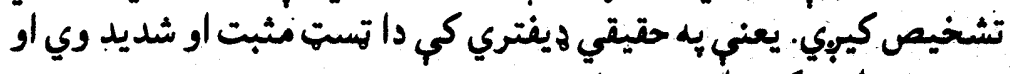

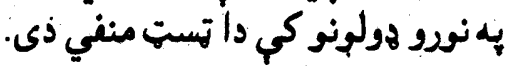

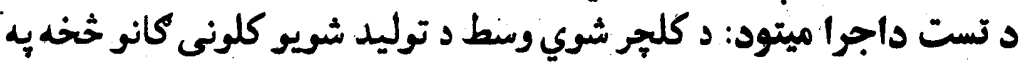

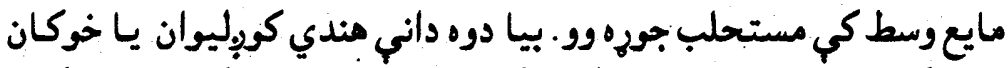

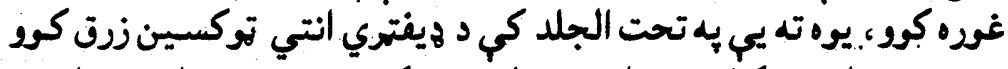

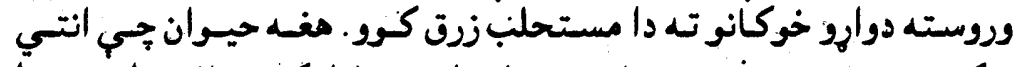

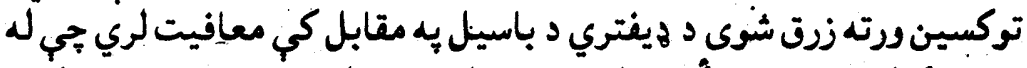

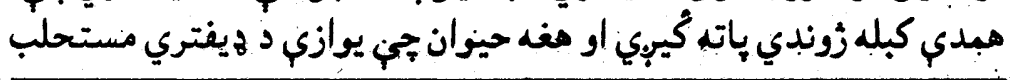


ورته زرق شويدنى د دي باسيل د توكسين له كبله له منخه حي. جي د حيوان

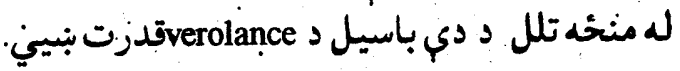

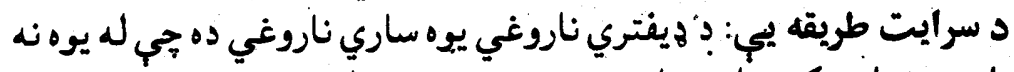

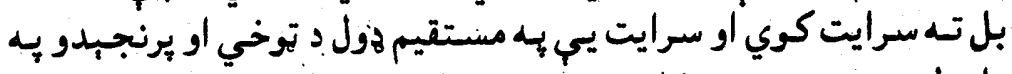

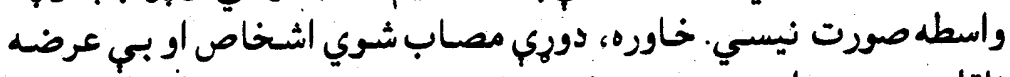

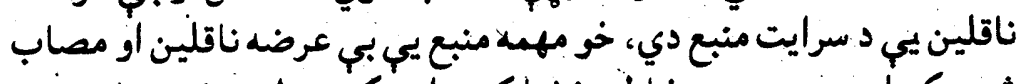

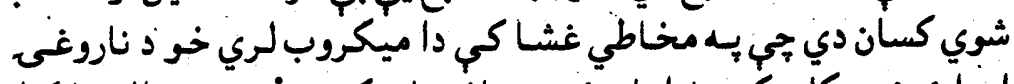

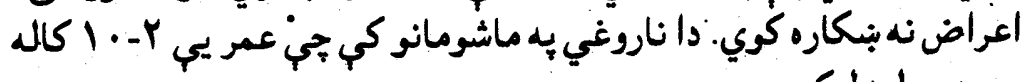

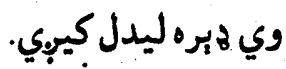

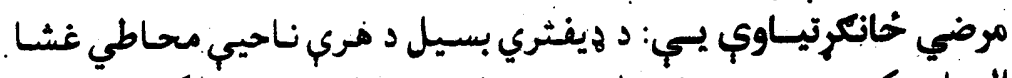

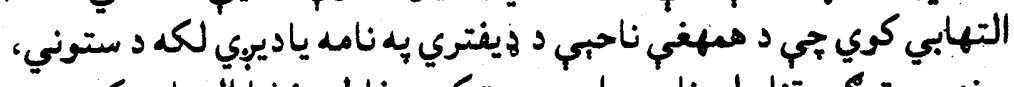

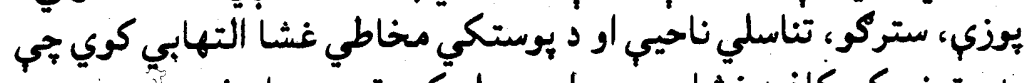

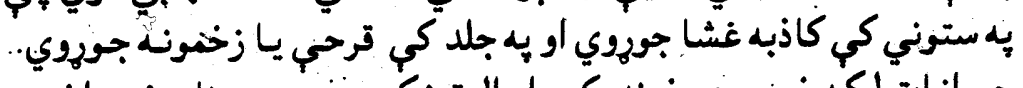

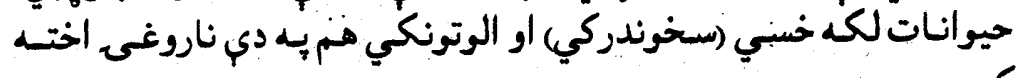
كيرِي.

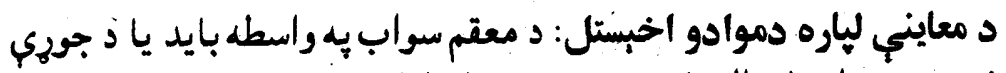

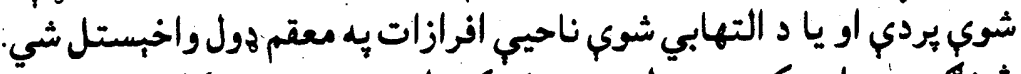

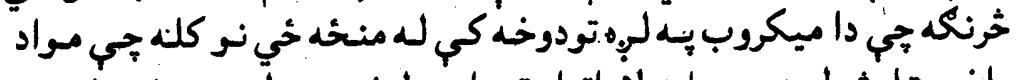

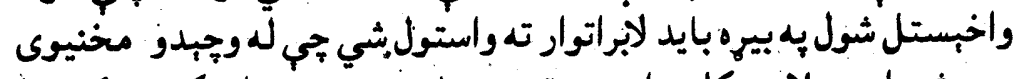

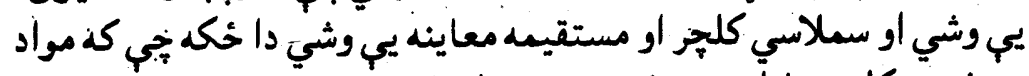

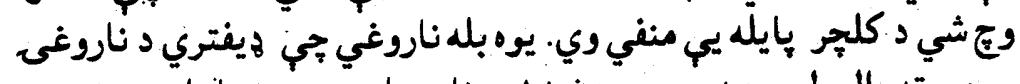

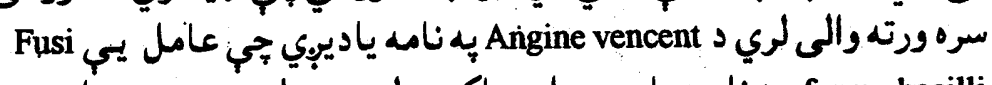
تئسل form bacilli تانسلونو يه مخاطي غشا باندي كاذبه غشئا جويسوي.

هغه بسيلونه جحي دديفتري له بسيل سره ورته والى لري:

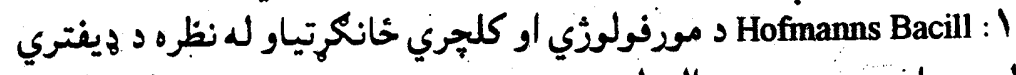
له بسيل سره هير ورته والب لري. 


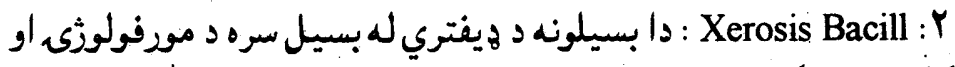

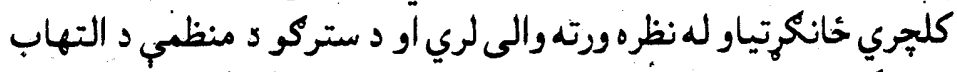
سبب كبربي.

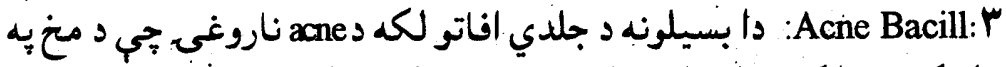

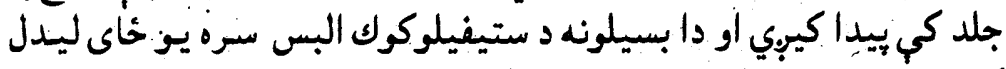
كيبِي.

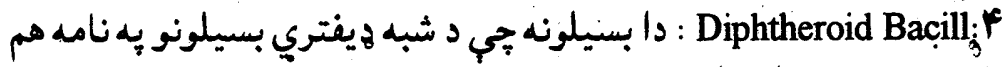

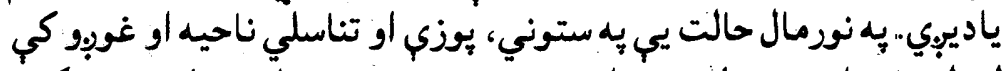

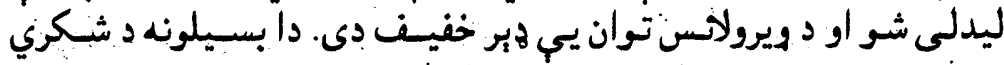

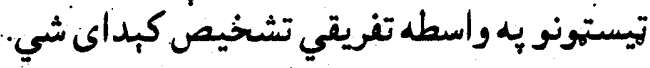

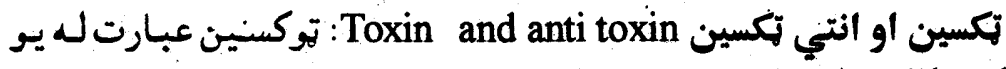

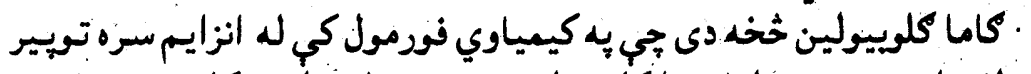

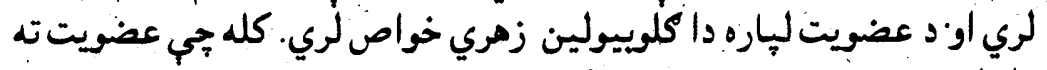

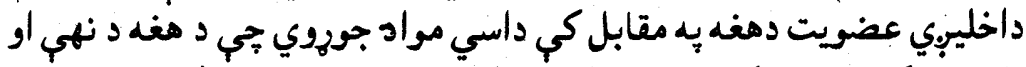

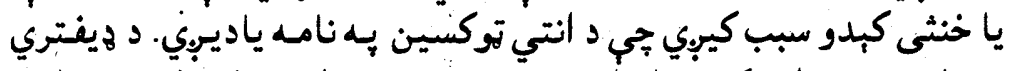

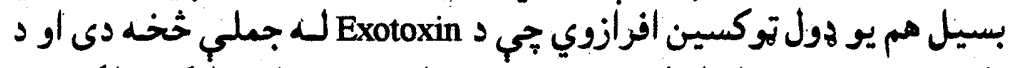

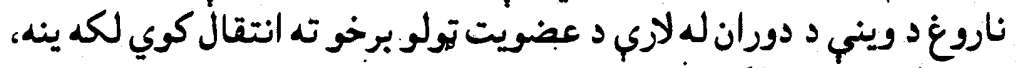

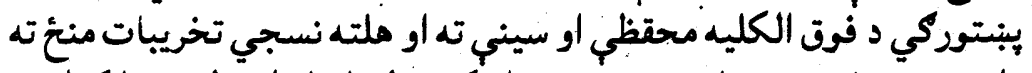

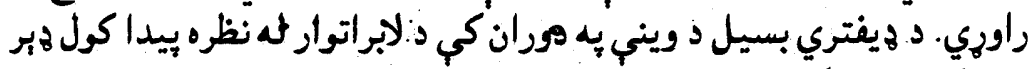

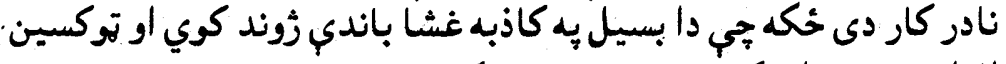

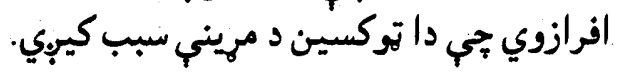

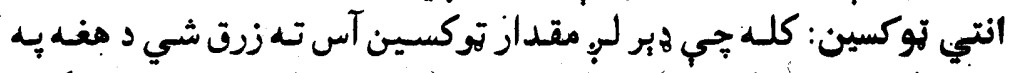

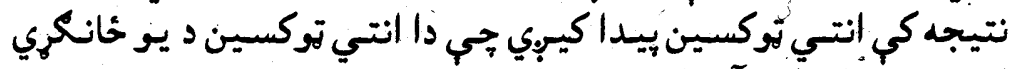

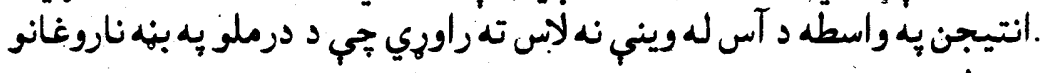

ته تطبيقيبيوي.

Toxid

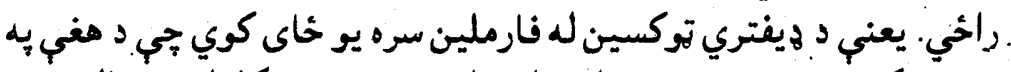

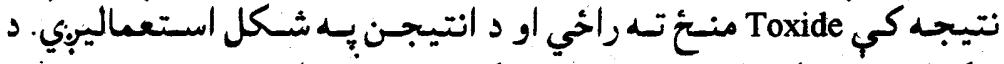

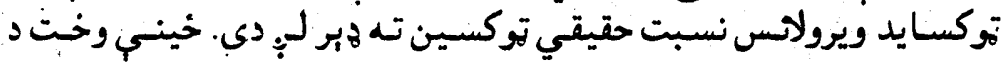

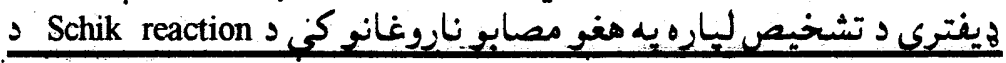




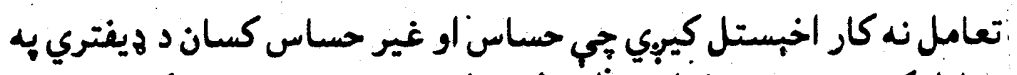

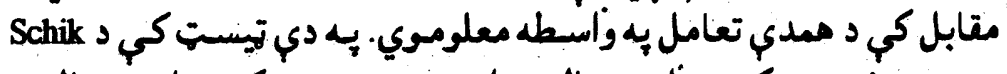

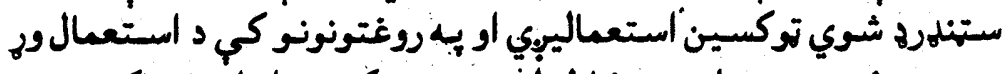

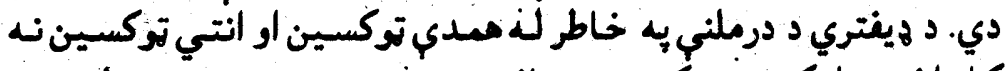

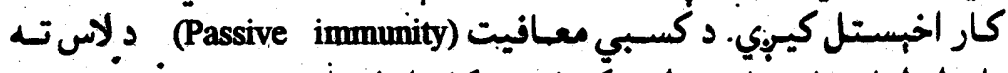

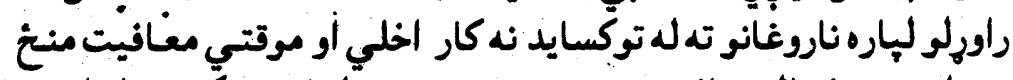

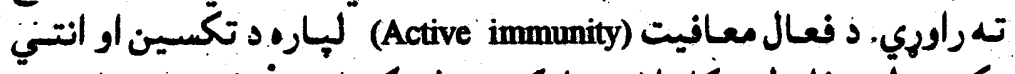

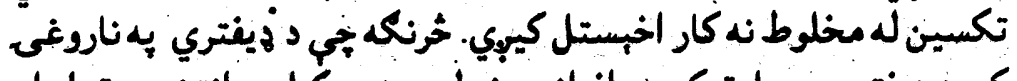

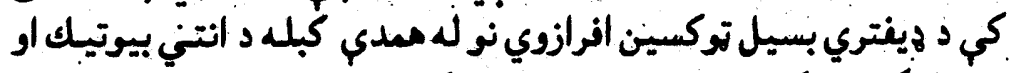

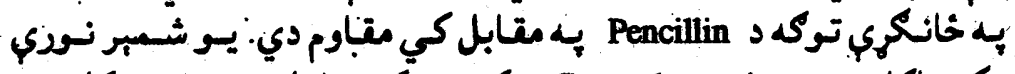

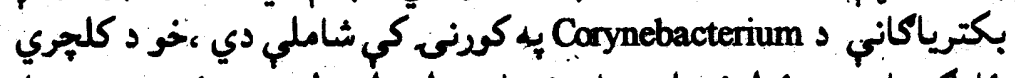

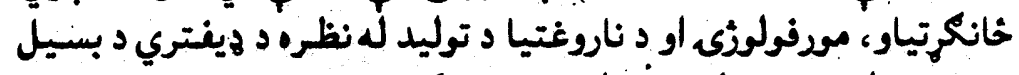

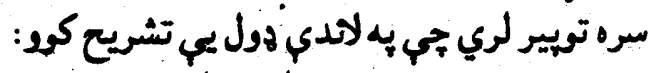

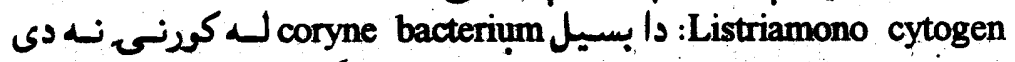

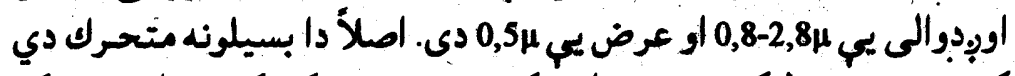

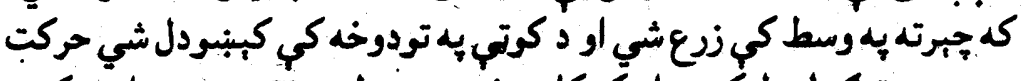

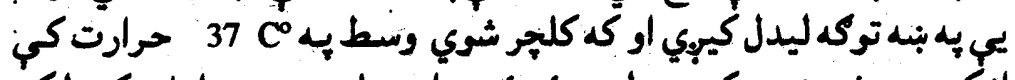

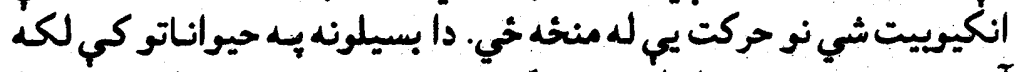

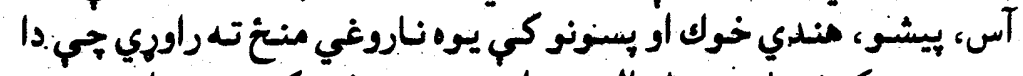

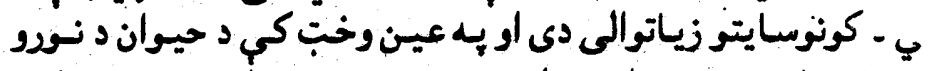

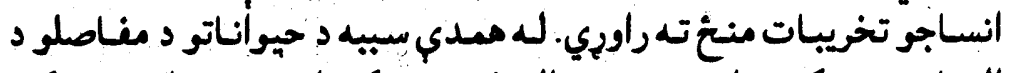

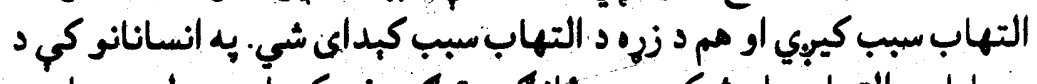

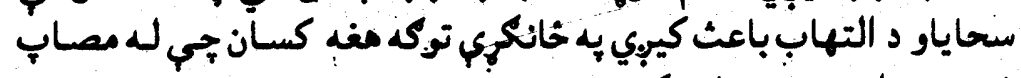

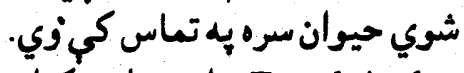
بryothri plax

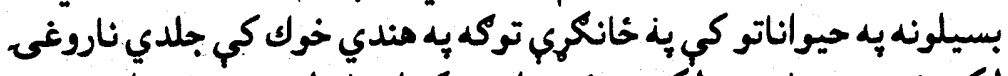

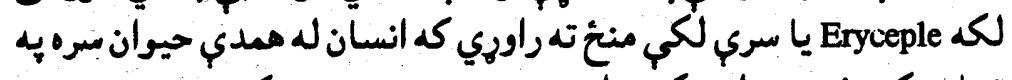

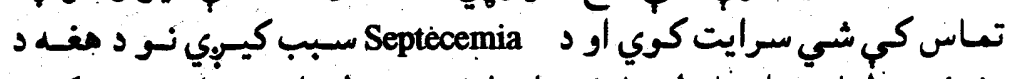

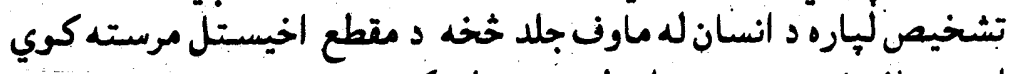
او د معاف شوي سيروم يواسطه يبي درملنه كبوي. 


\section{Acid-fast Bacill .}

مايكوباكتزيوم (Mycobacterium)

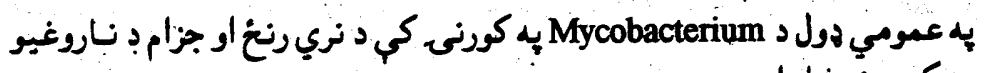

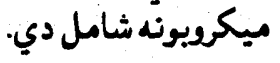

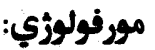

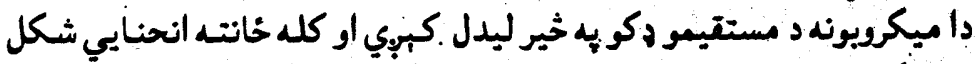

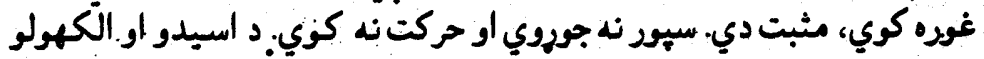

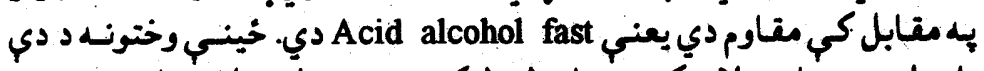

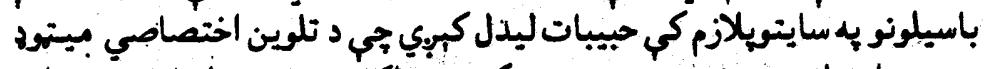

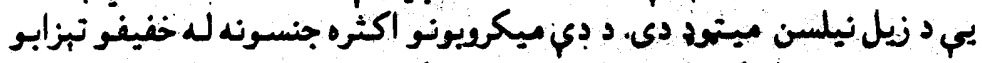

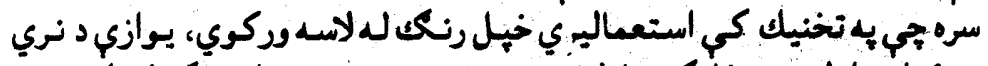

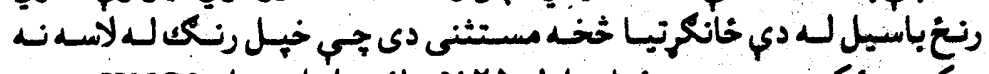

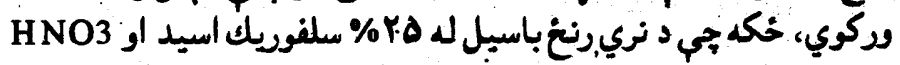

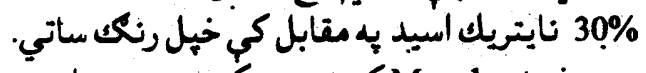

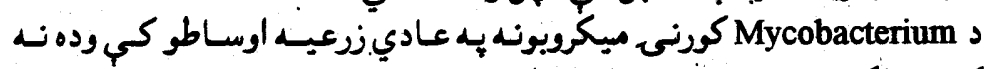

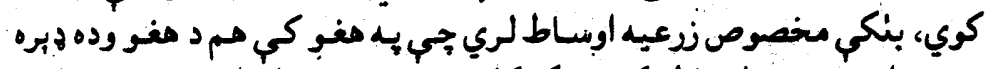

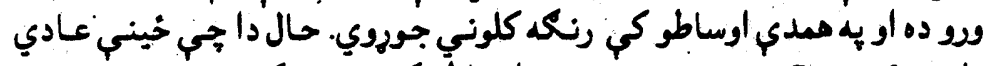

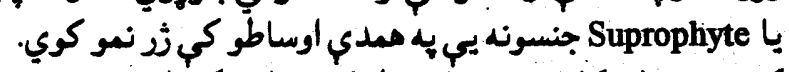

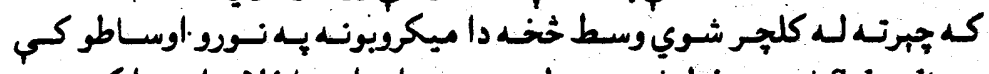
دubculture

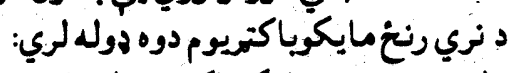

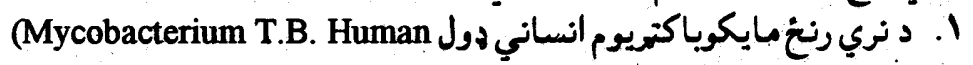
type).

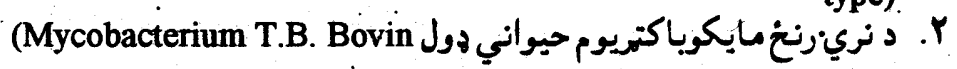
type) 


\section{Tuberclosis bacilli (Human type)}

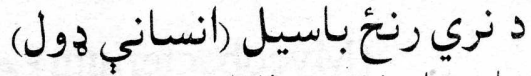

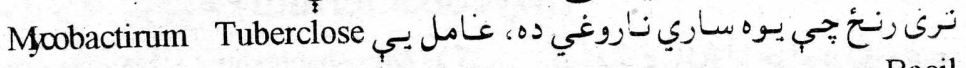
دacil

د دنري رنخ د باسيل مورفولوزي:

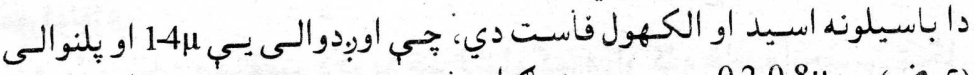

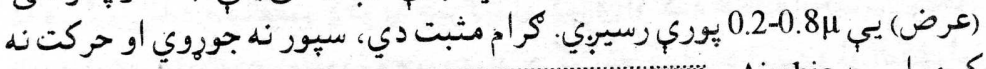

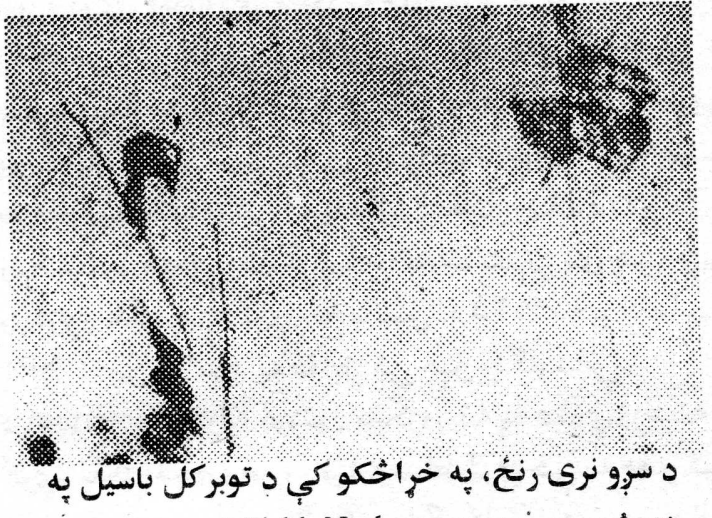

هبر نشمير موجود دى. Ziehl- Neelson نلوين.

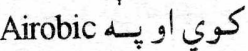

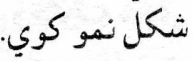

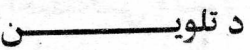

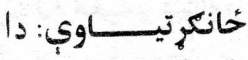
باسيلونه د تلوين بيه عادي مبنودو رنكك

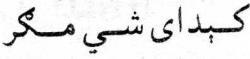
وصفيست يسكي يستيه صحيح جول نه ليدل

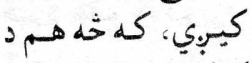

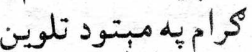

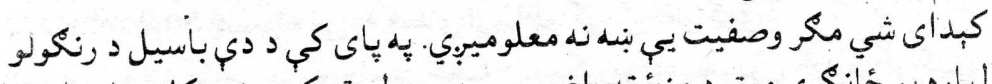

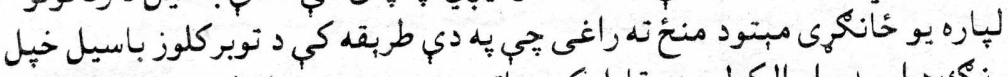

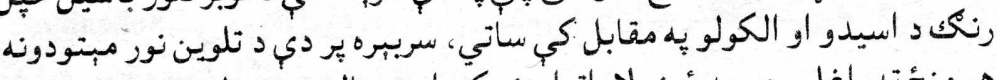

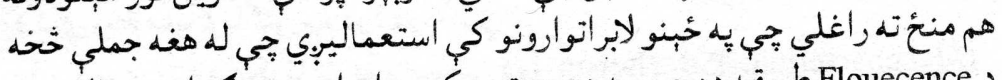

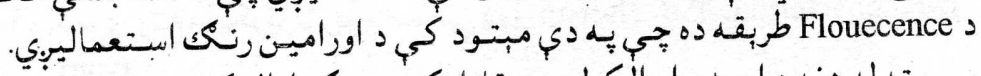

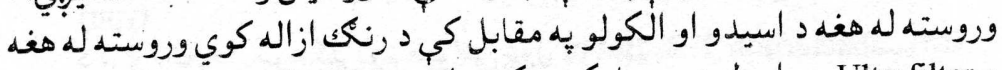

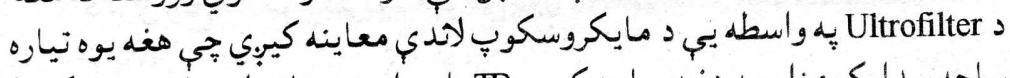

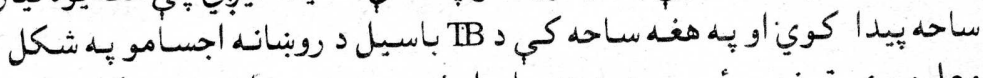

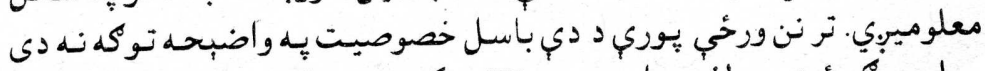

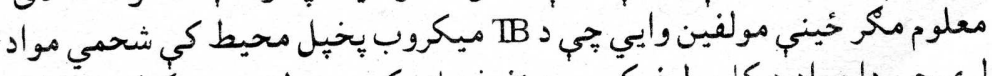

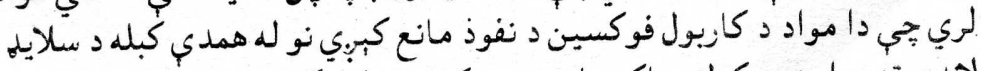

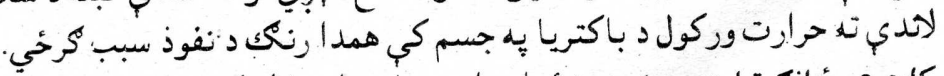

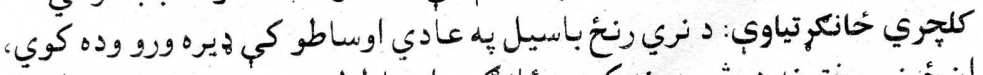

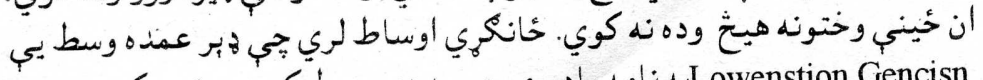
Lowenstion Gencisn 
وسط به تركيب كي كليسرين، هكئ أو معدني مالكي موجودي دي. نوز اوساط

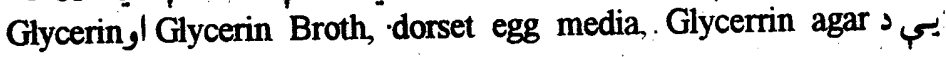
Potato

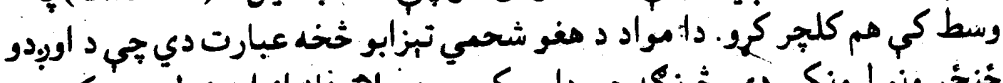

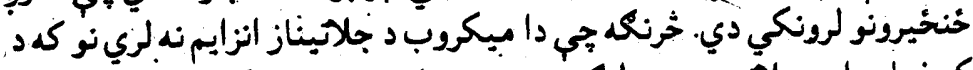

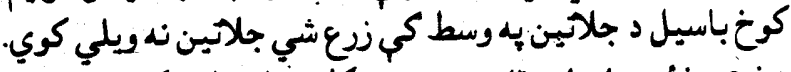

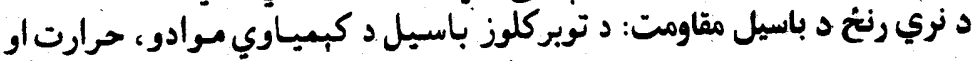

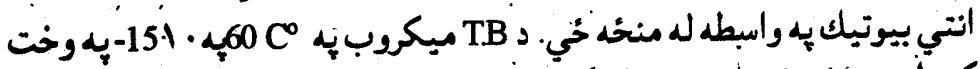

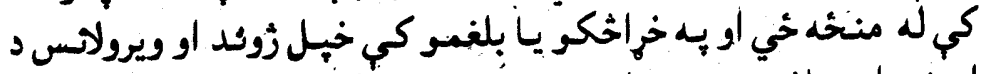

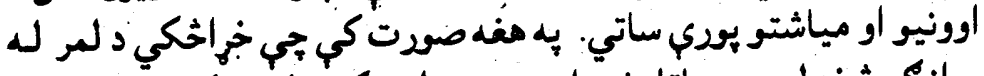

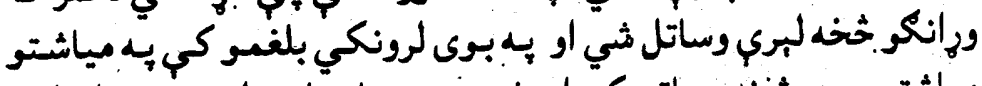

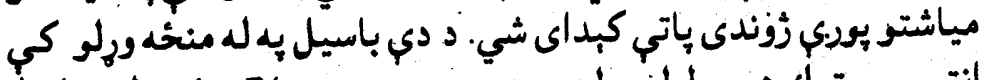

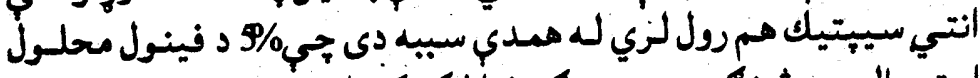

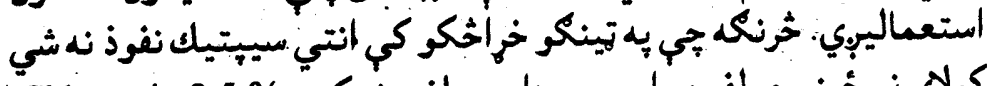

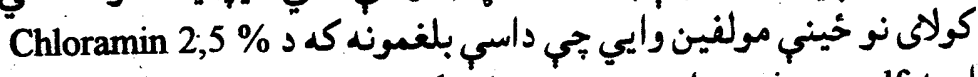

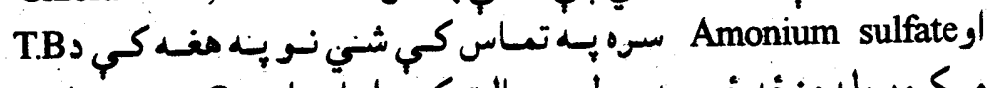

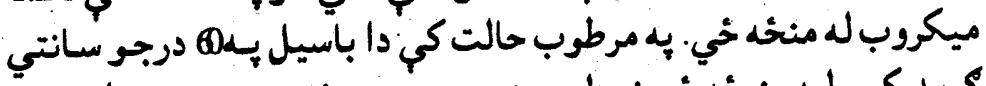

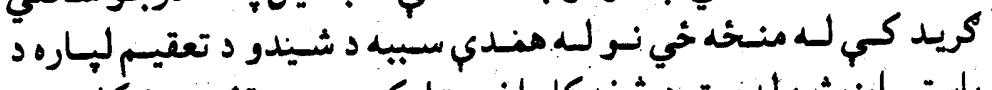

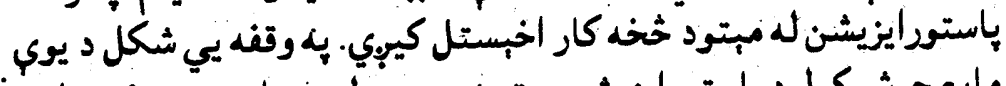

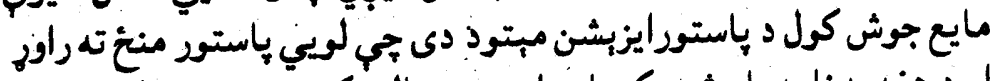

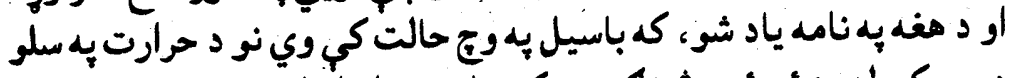

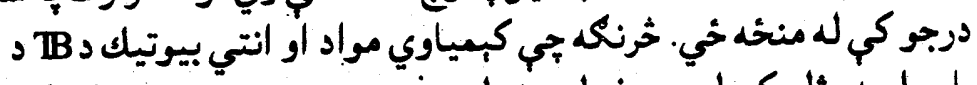

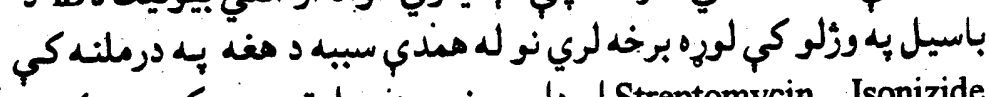

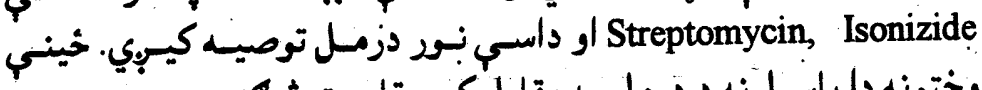

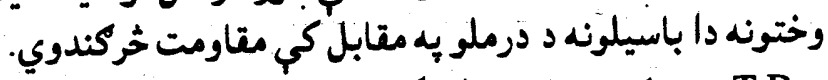

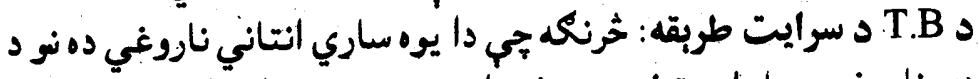

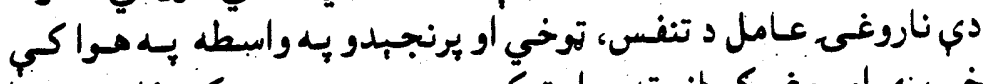

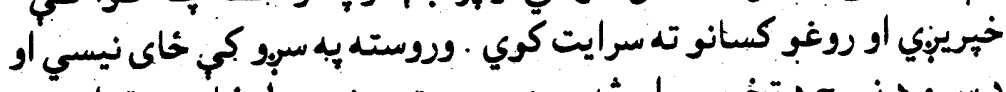

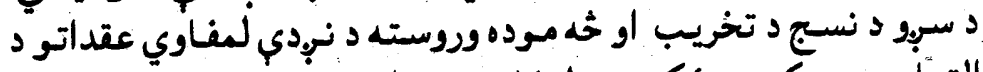

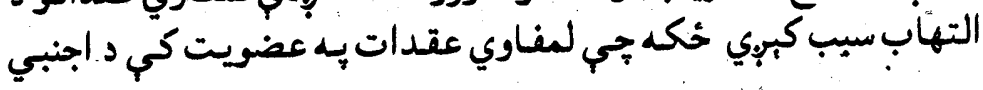


اجسبامو د بلع كولو وظيغه لري جي دي حالت ته ابتدايي تويركلوزي مرحله وايي.

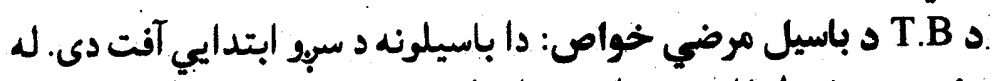

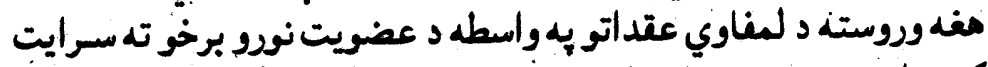

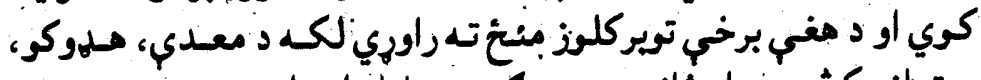

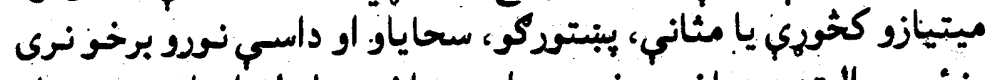

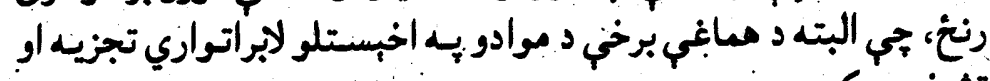
تشخنيص كيبِي. توبركولين (TUBERCULIN): تويركولين د تويركلوز د باسيل يو ذول

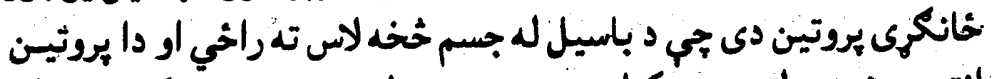

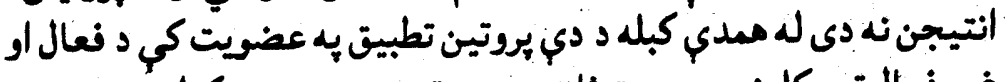

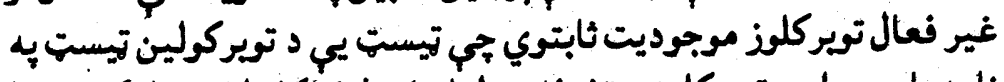

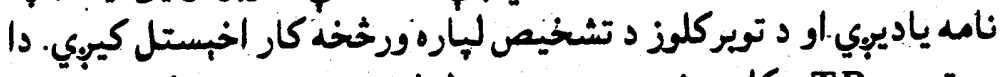

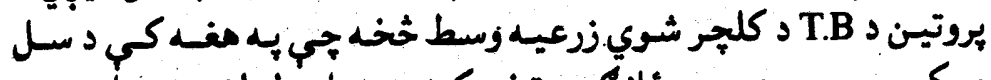

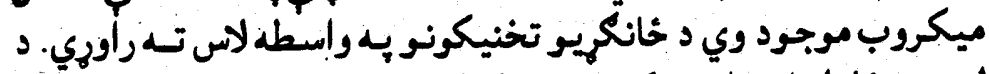

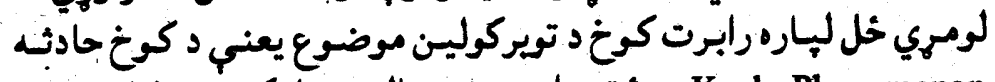
باسئم Koch Phenomenon

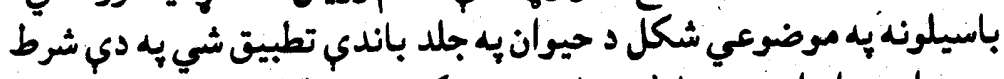

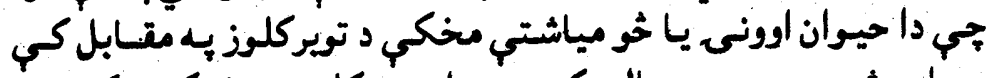

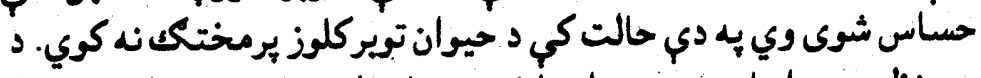

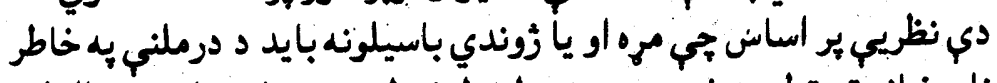

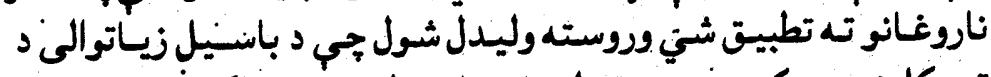

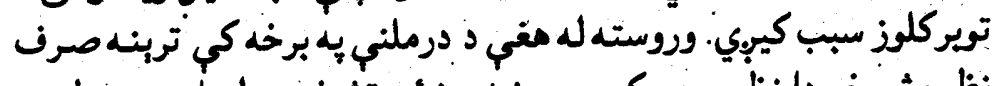

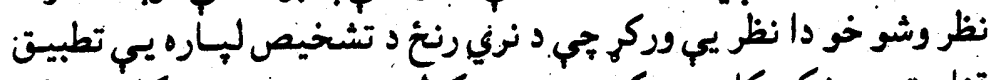

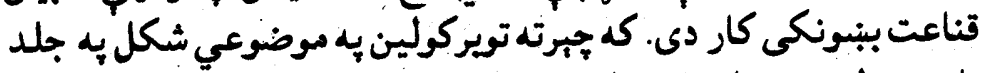

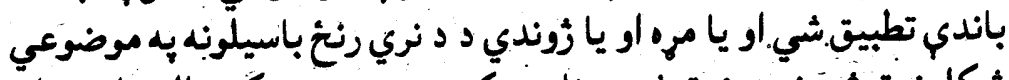

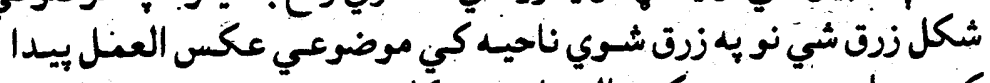

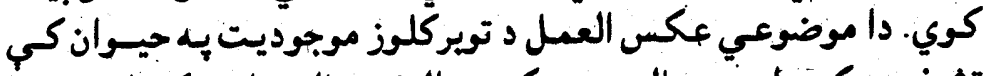

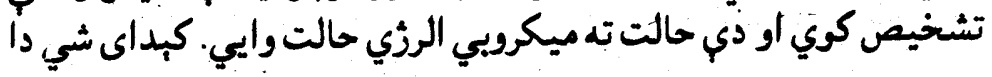


موضوعي مالت عمرمي مالت ته شامل ثي لكه د تبي،كسالت او د وزن

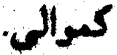

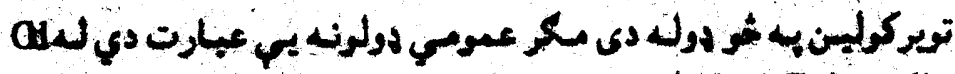
in Purifid Protica Tubercolin \& Koch Tubercolin

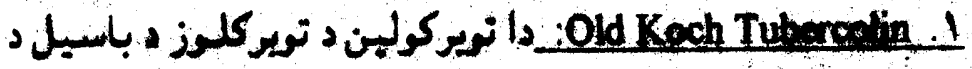
كائم Sا توبركلوليسن PURIIDE PROTIEN TURERCOLN Y Old Koch Tubercolia

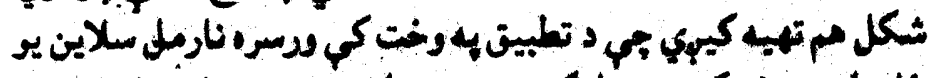

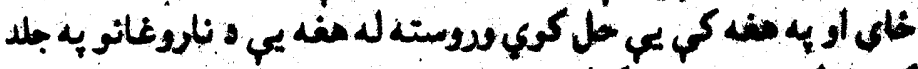

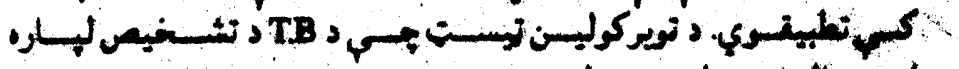

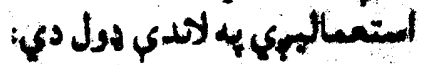

Mondaux Test :1

Pratirest : 2

Jell Tubercolin Test :3

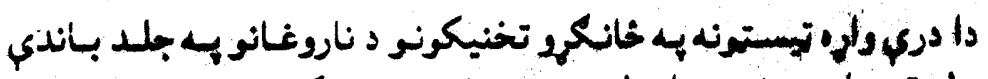

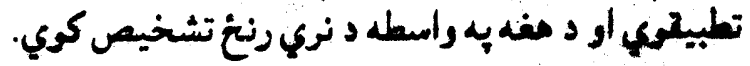

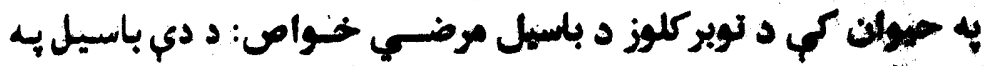

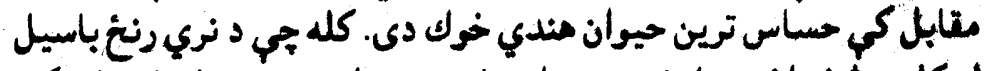

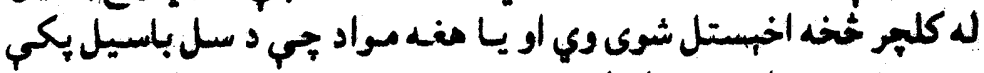

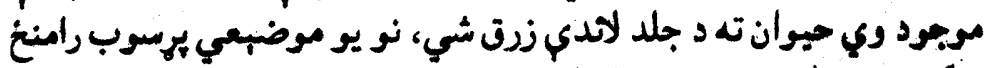

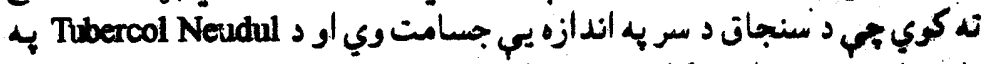

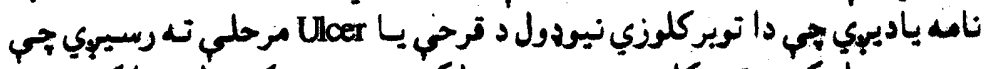

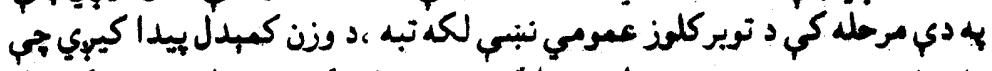

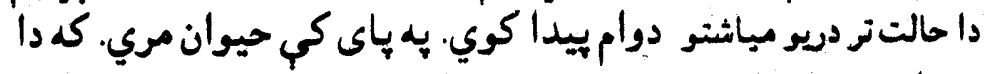

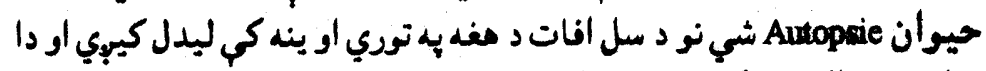

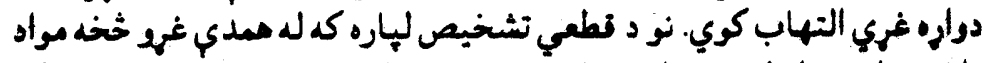

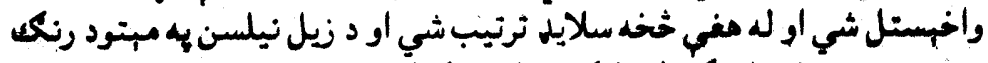

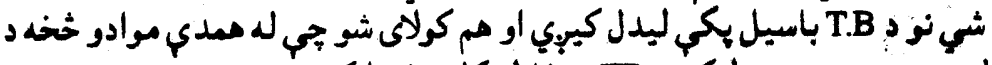

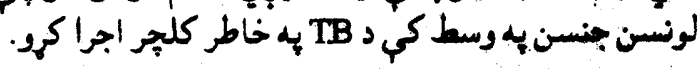


د د.B د باسيل به مقابل كي مغافيت: خرنكه جي نرى رنتخ يوه ساري

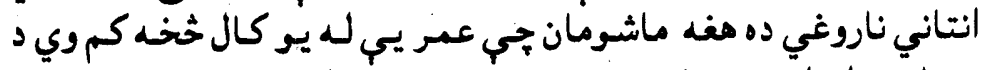

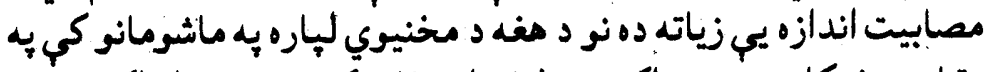

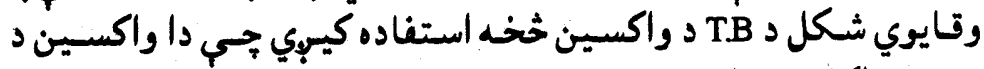

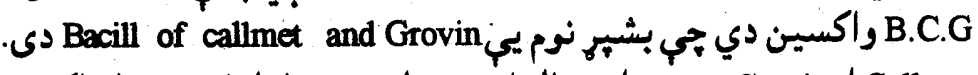
Grovingl Callmet

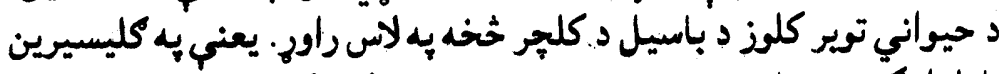

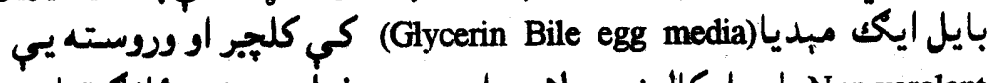

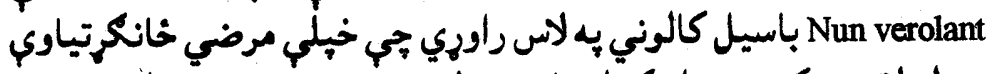

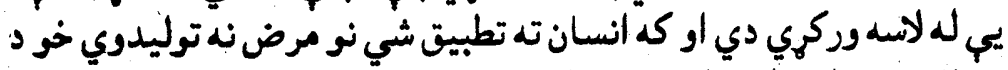

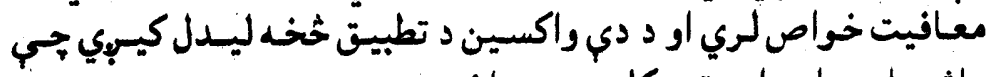

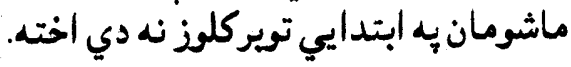

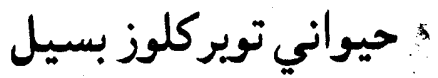

\section{Tuberclosis Bacill BovinType}

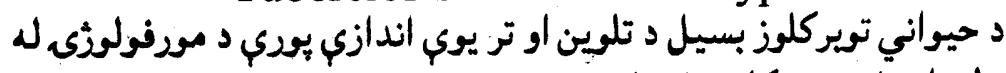

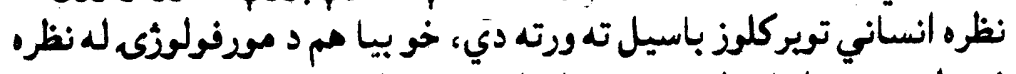

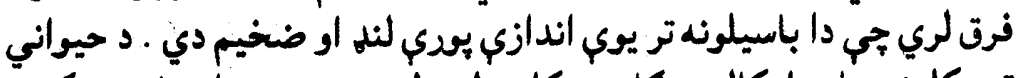

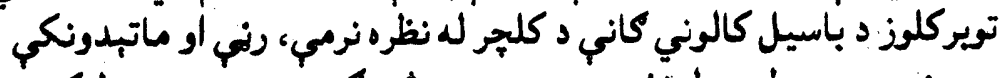

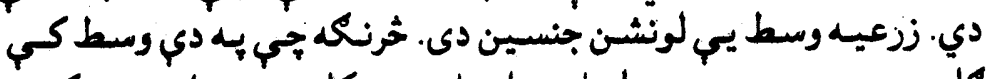

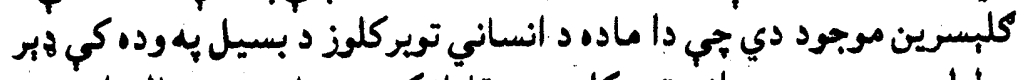

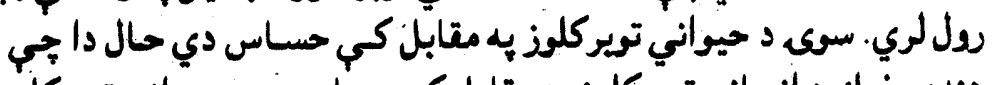

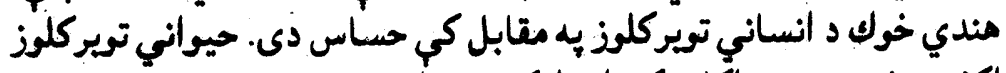

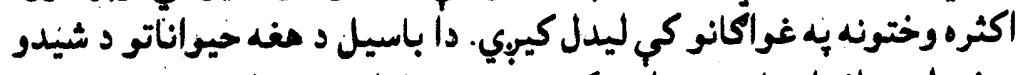

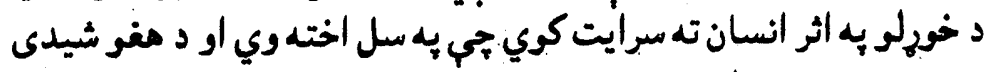

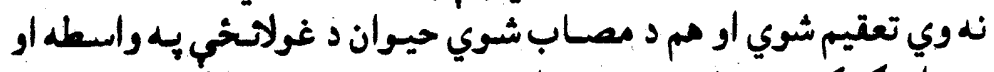

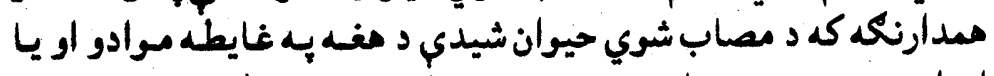

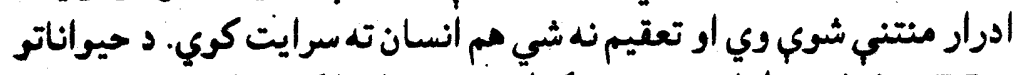

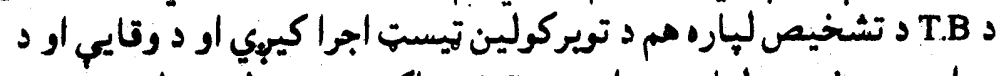

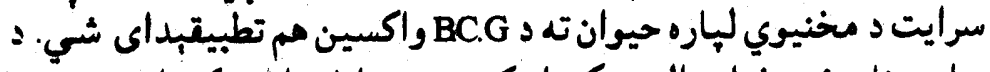

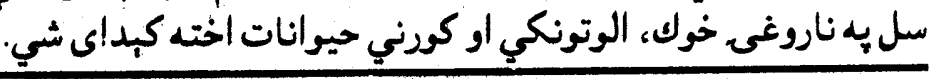


به لابراتوار كي د توبر كلوز د بسيل تشخيص: لابراتواري نشخيص يـ دري خوله صصوت نيسي:

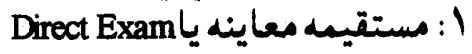

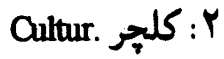

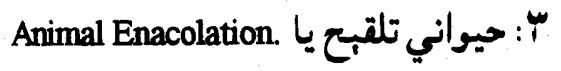

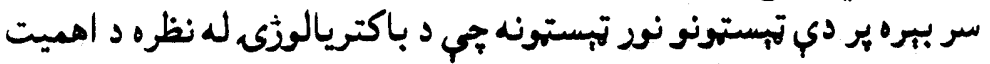

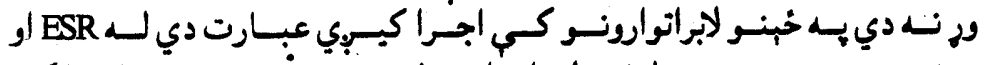

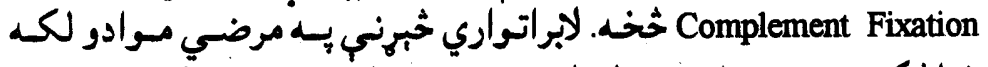

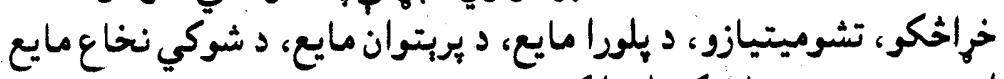
او د معدي به عصاره كي اجرا كيبيوي.

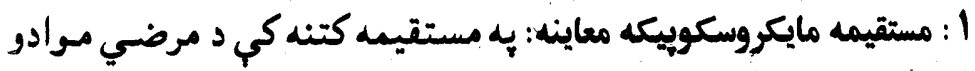

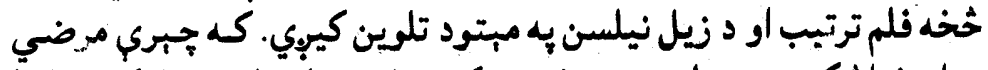

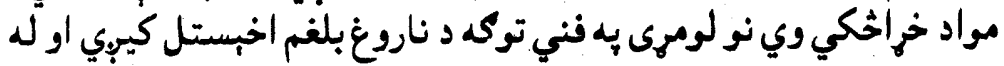

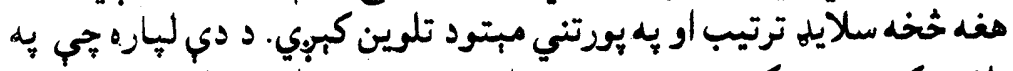

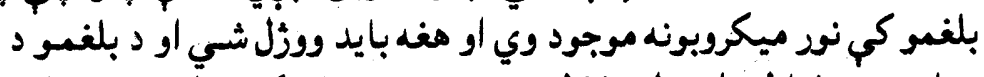

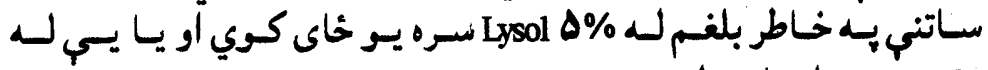

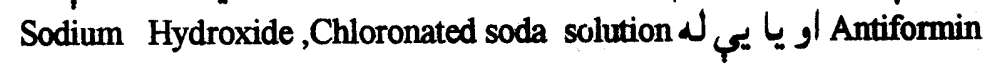

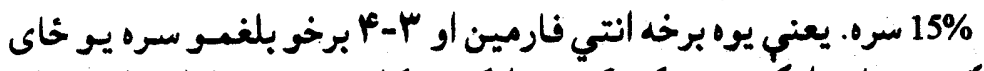

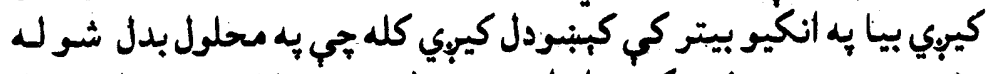

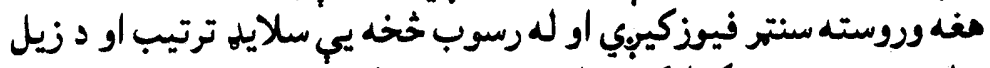

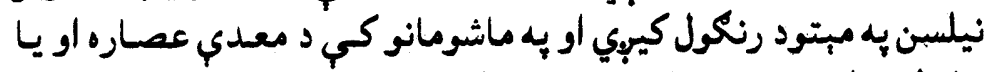

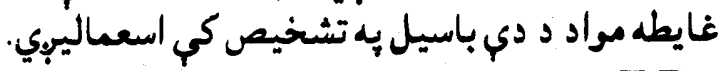

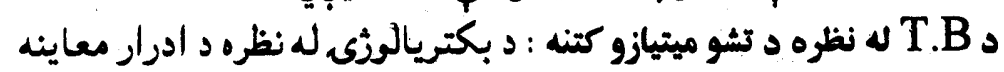
اهميت لري.

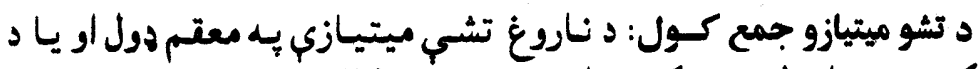

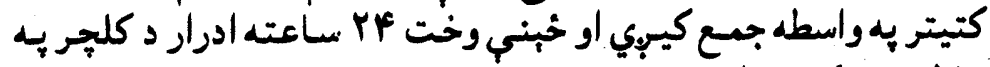

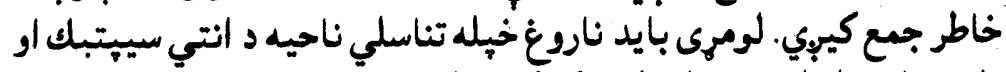

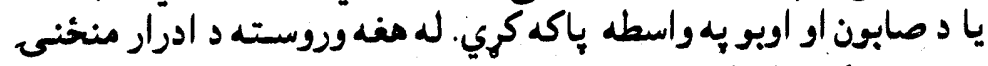

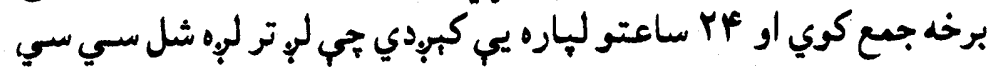




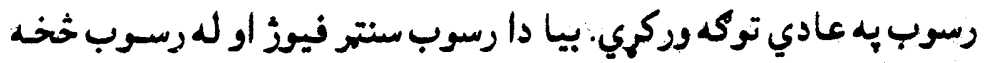

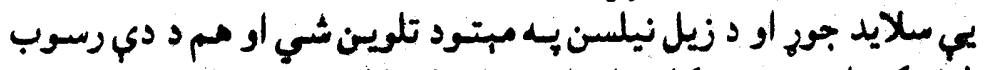

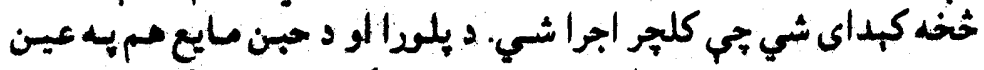

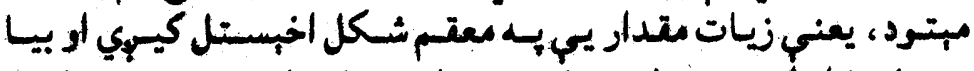

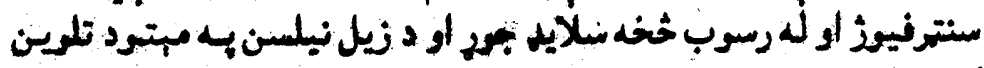

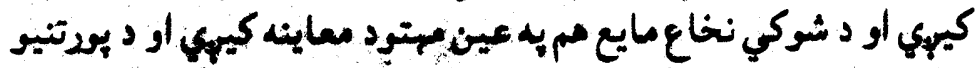

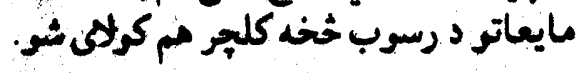

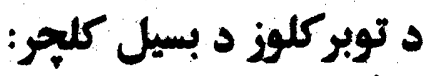

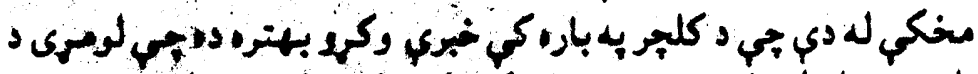

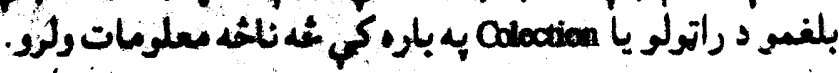

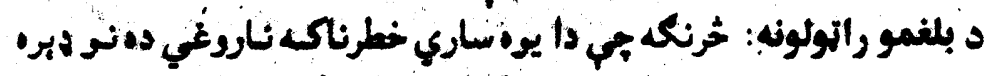

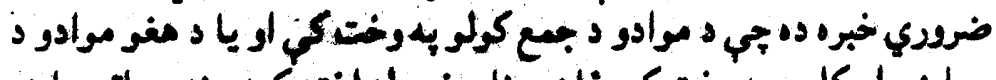

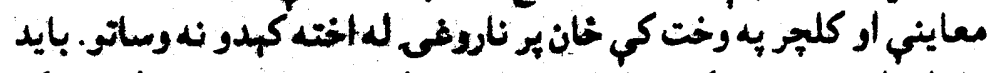

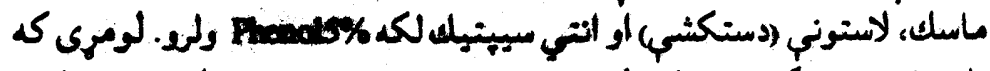

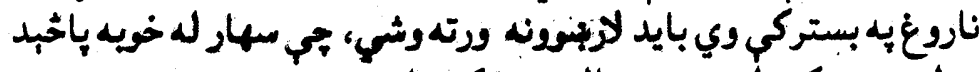

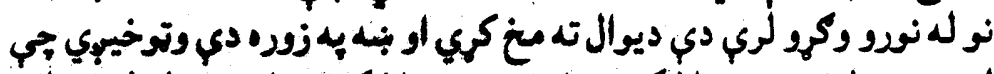

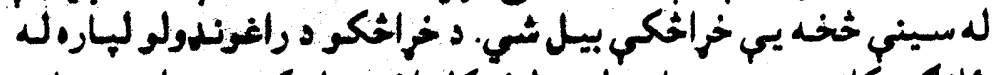

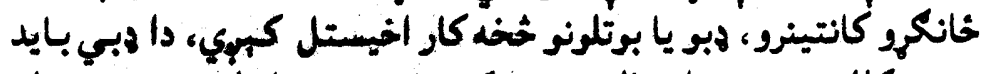

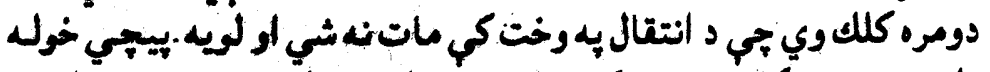

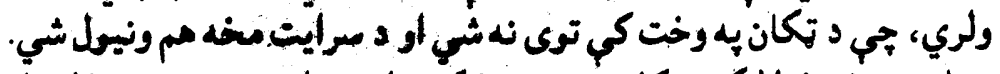

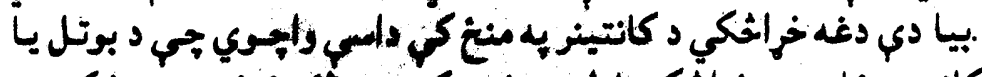

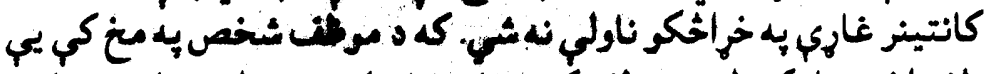

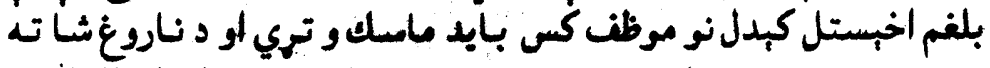

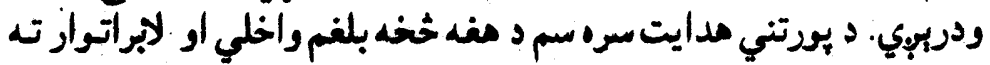

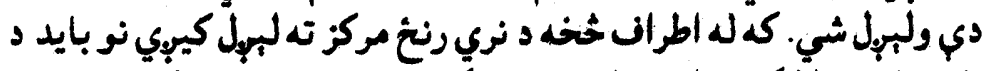

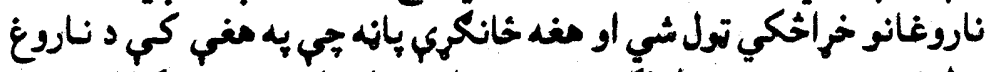

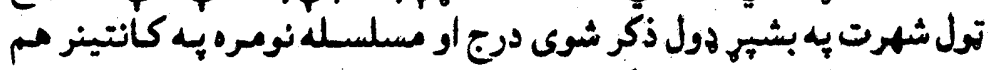

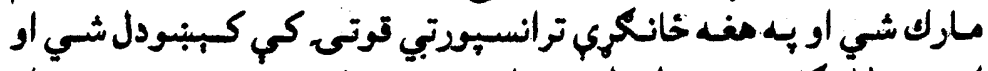

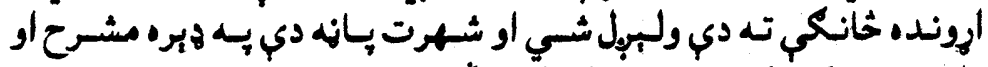

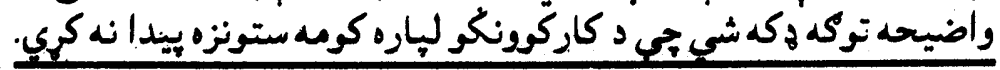


د نويو او تداوي شويو ناروغانو به برخه كي مم بايد دا ذكر شي جيمي نوي

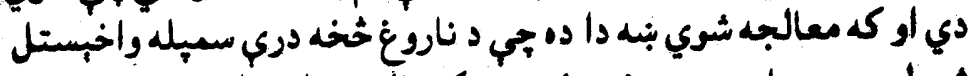

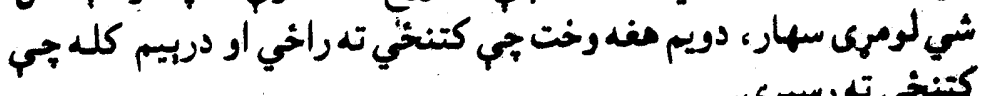
كتنخي ته رسيوي.

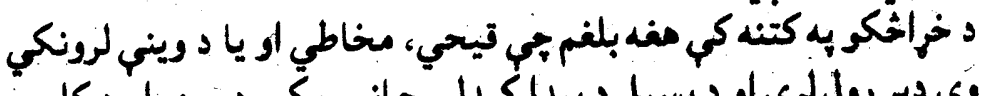

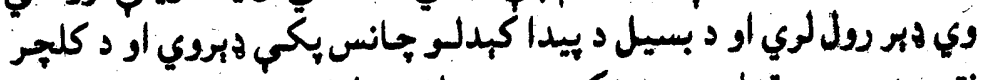

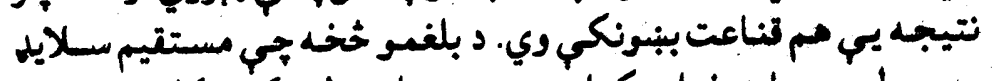

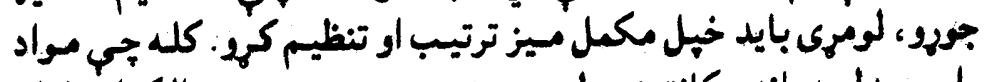

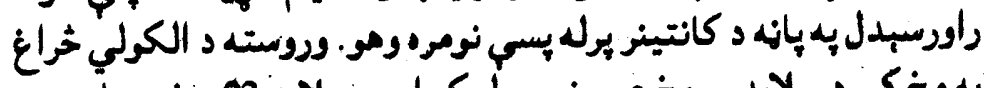

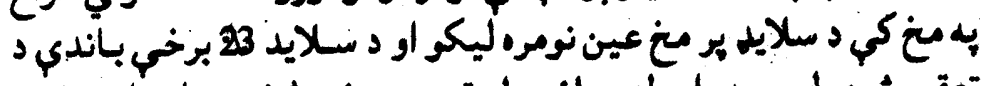

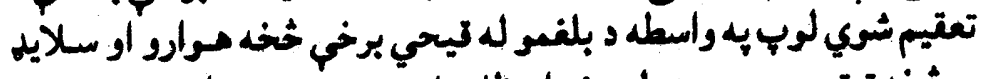

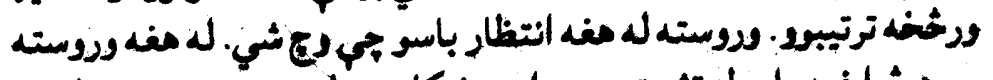

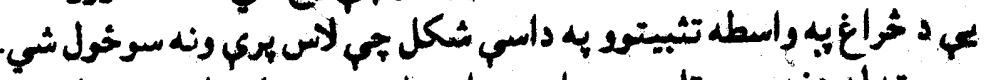

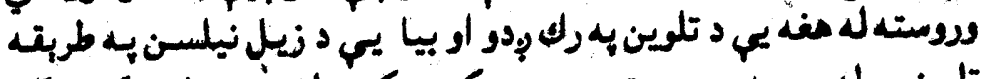

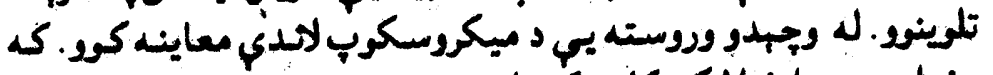

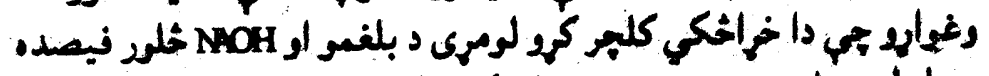

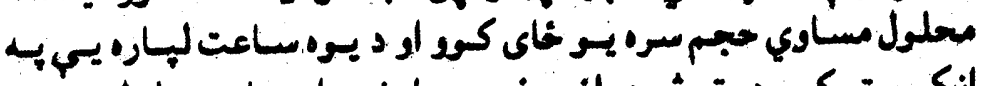

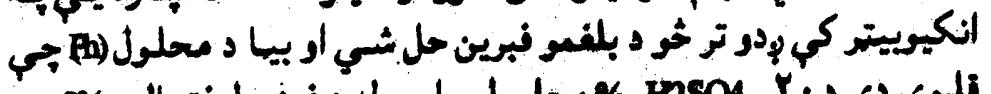

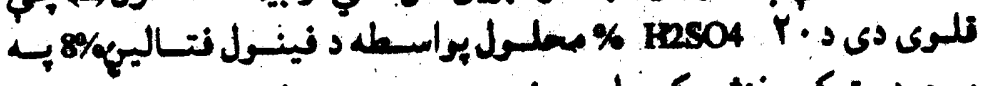

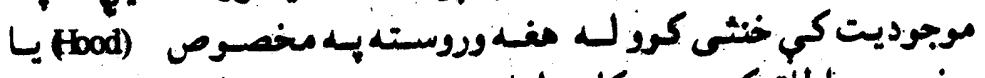

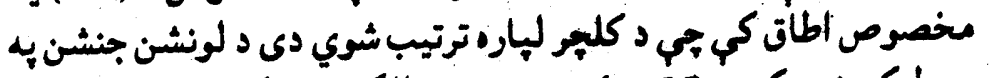

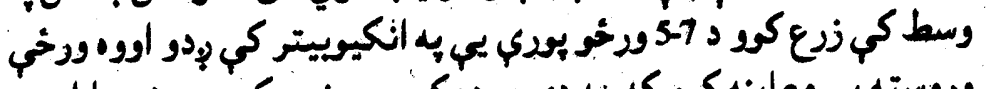

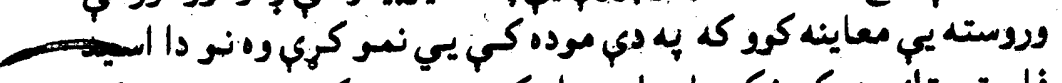

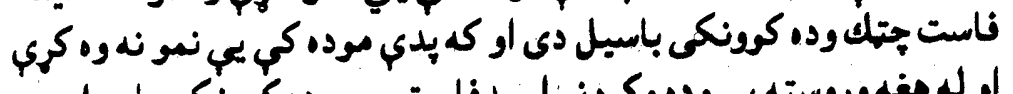

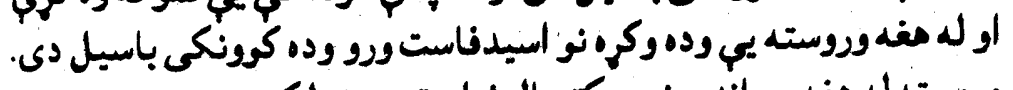

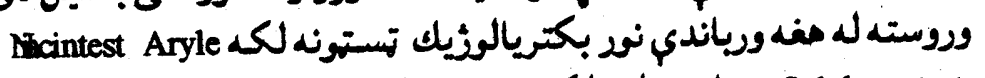

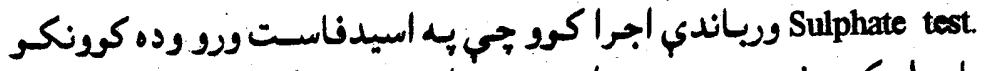

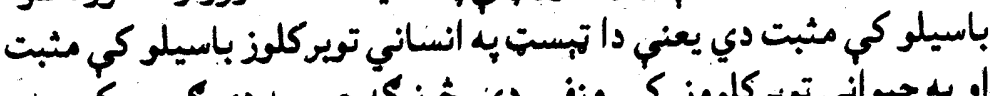

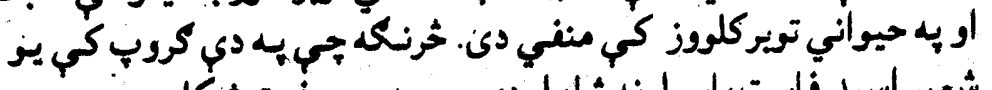

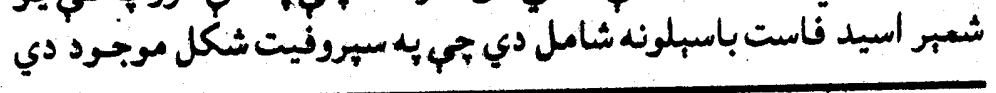




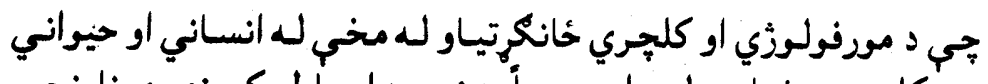

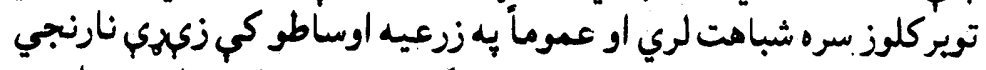

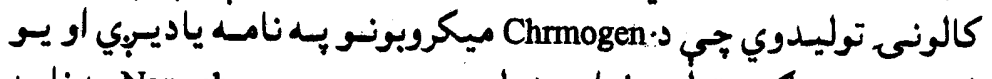

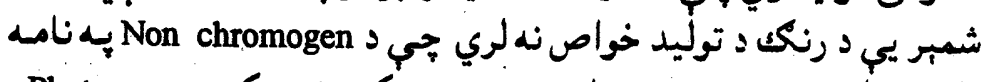

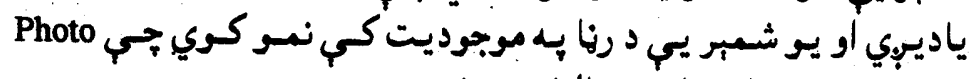

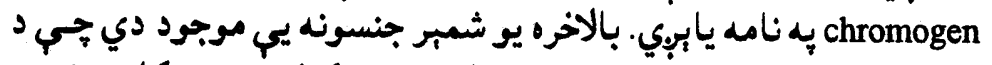

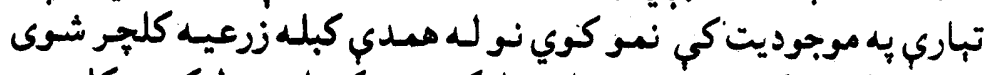

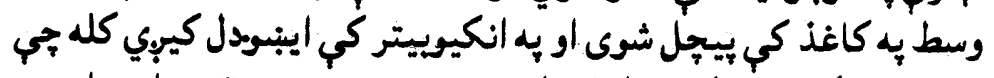

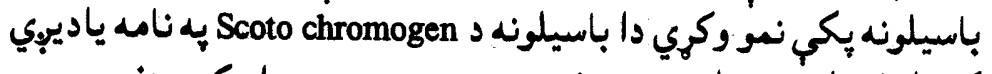

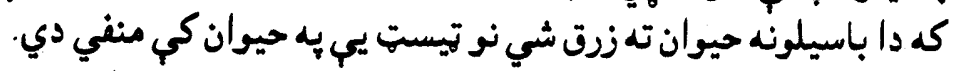

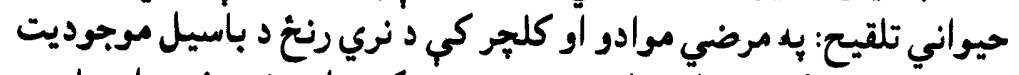

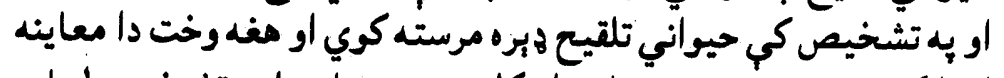

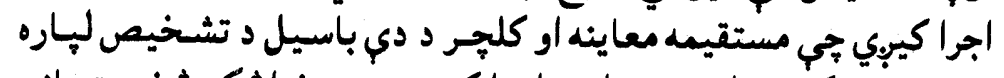

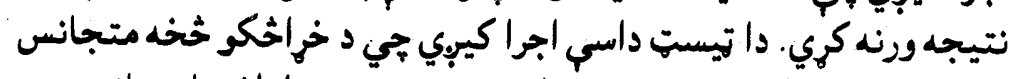

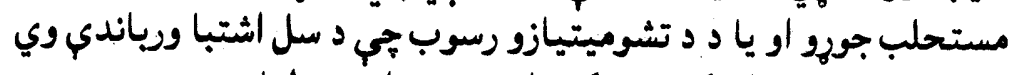

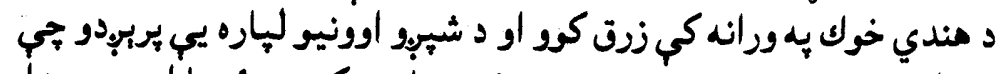

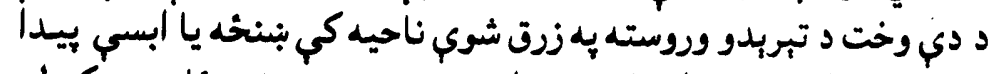

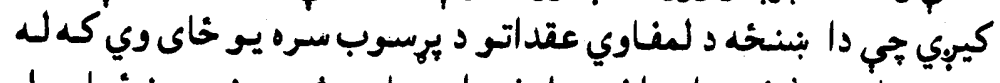

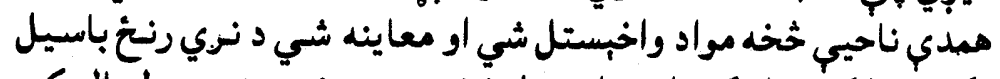

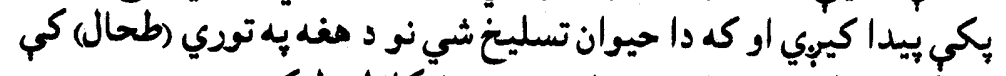

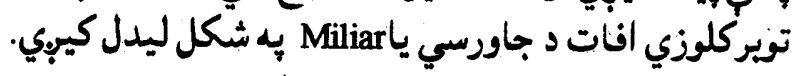

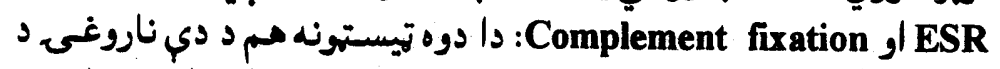

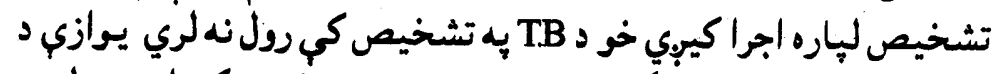

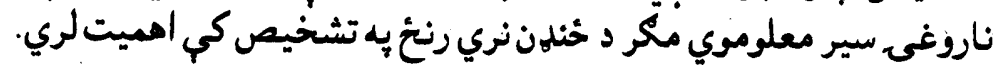

\section{د اسيد فاست باسيلونو نور هولونه}

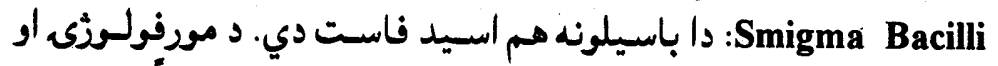

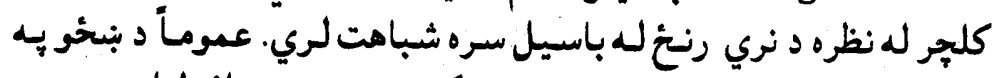

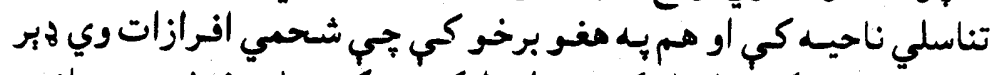

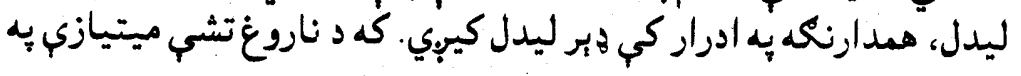




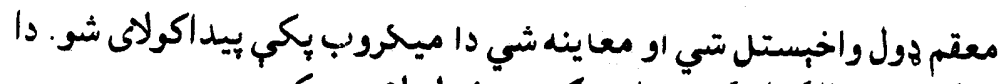

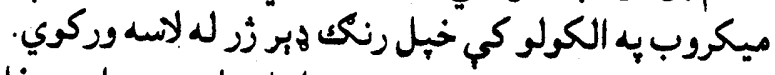

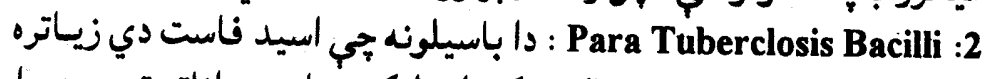

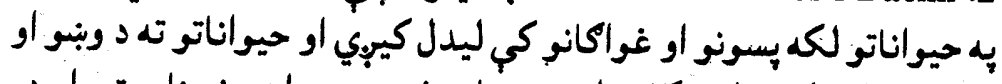

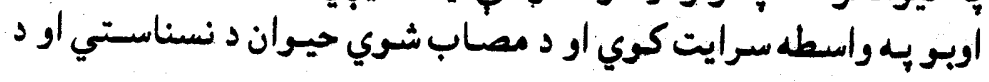
كمزورى سبب كبري.

Attypic Acid fast bacilli :3

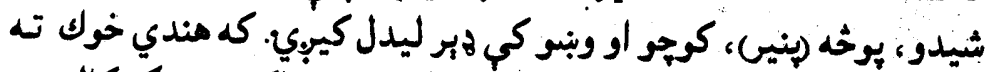

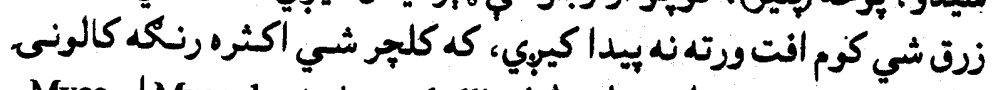

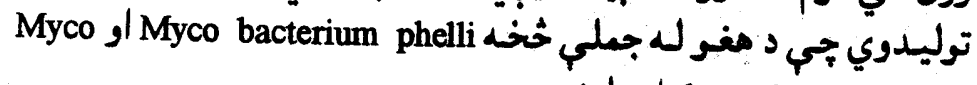
bacterium sterio coli 


\section{Mycobacterium Leprea}

Leprosy Bacilli مورفولوزي او تلوين:

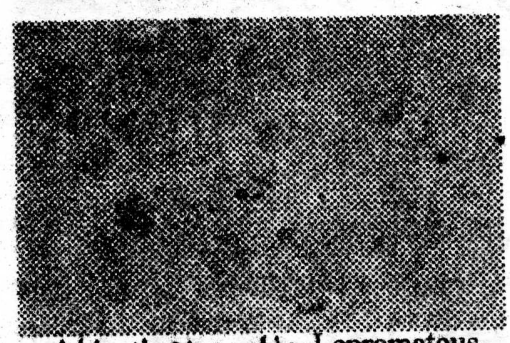

(ج) Lepromatous

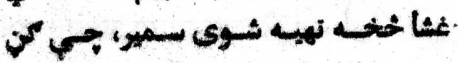

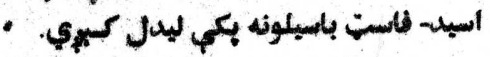
Ziehl- Neelson s
دا باسيلونه جي د جذام دون ناروغى عامل دي جلدي، مخاطي غشا او

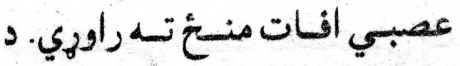
مستستيمو 8كو يسهـ شــكل ليسدل

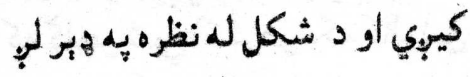

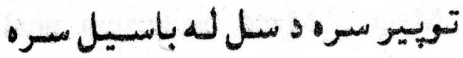
شـباهت لـري. نومسوري بســيلونه

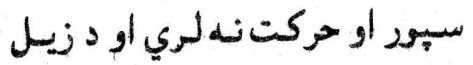
نيلسن به ميتود تلوين كيبوي مكري

20\% H

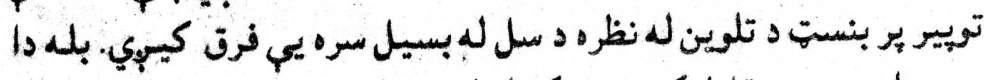

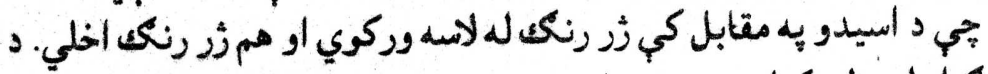

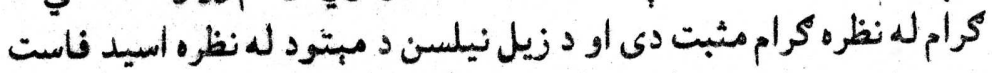

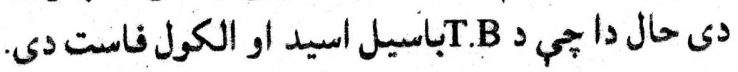
كلجري خانكوتياوي: يه كؤم زرعي وسط كي بحي دا بسيلونه كلهر شوي دي نمو يبي نه ده كري

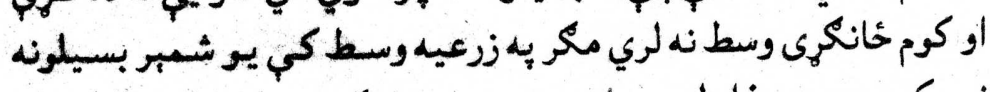

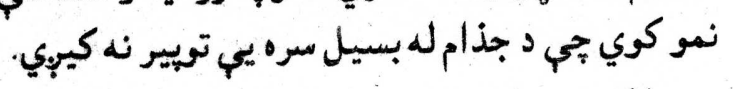
د جذام د بسيل تلقيحي حانكيرتياوي: د جذام د بسيل يه مقابل كي تر

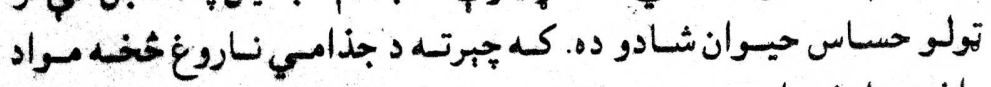

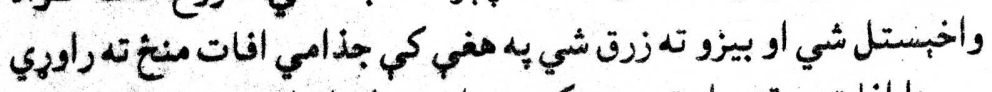

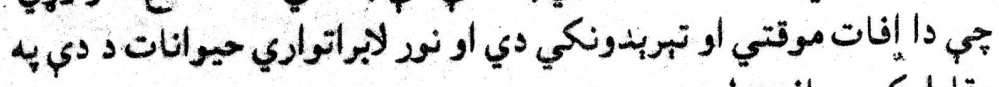

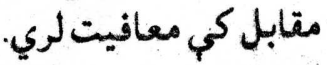


هذام د بسيل مرضي خُانكرتياوي:

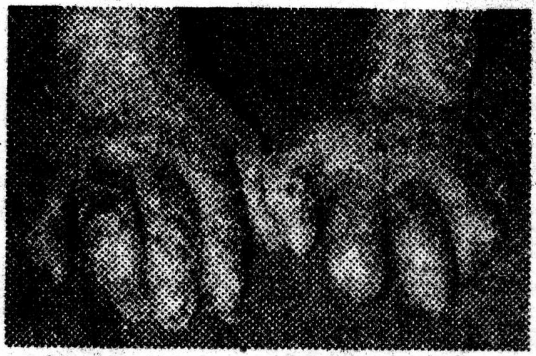

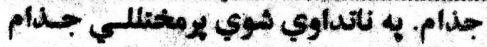

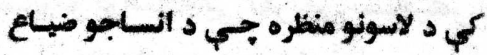
بكي بـ وضاحت معلوميري ئي.

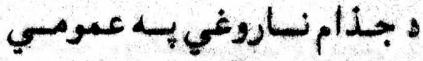

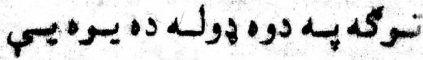
Lepromatose Type Tubercloid Type

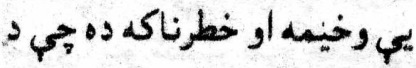
جلدي، مخاطي غشا او عصبي

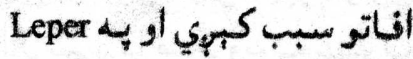
cells

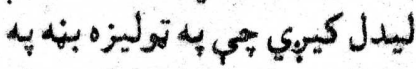

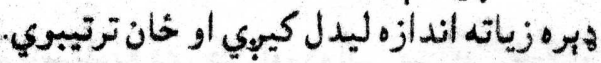
Tubercloid Type

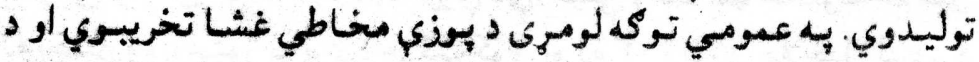

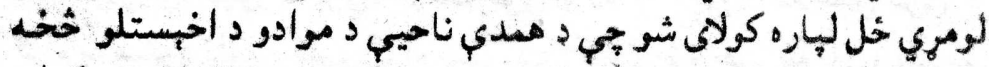

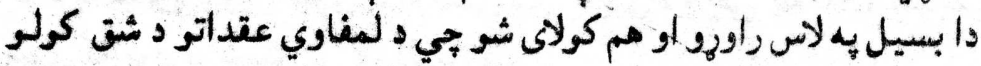

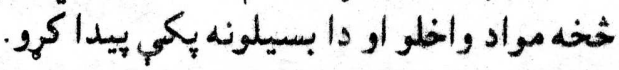

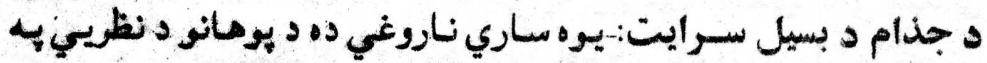

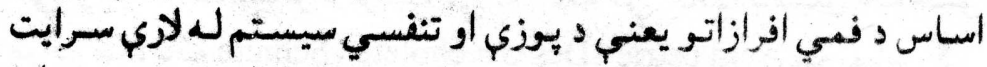

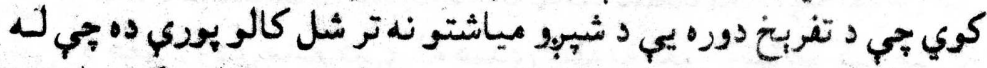

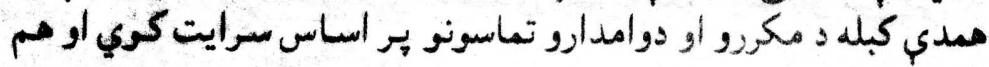

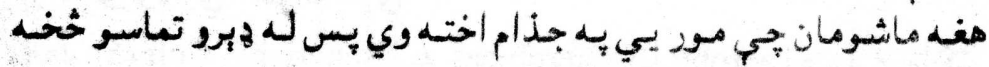

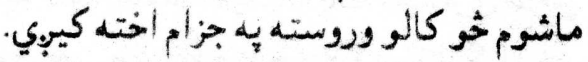
د جزام د باسيل لابواتواري تشخيص:

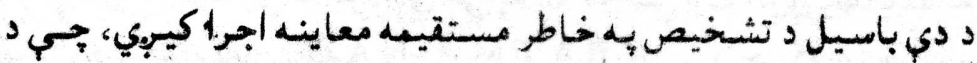

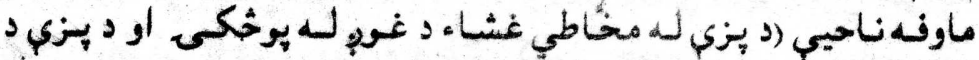

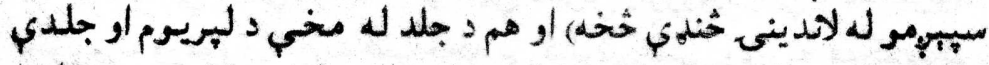

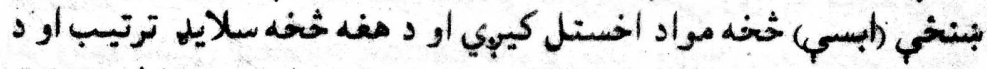

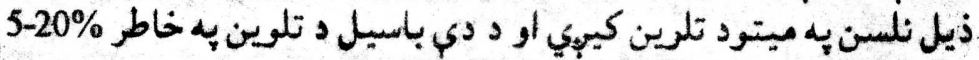
سلفوريك اسيد استعساليبوي. 


\section{ايشريشيا كولاي (Escherichia Coli)}

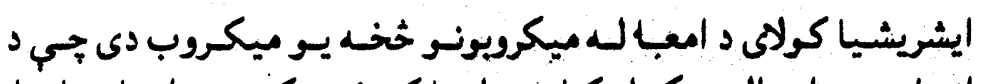

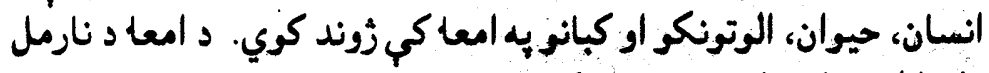

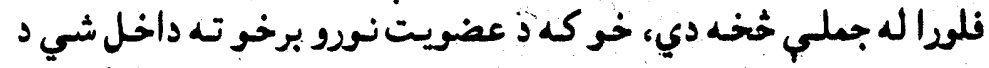

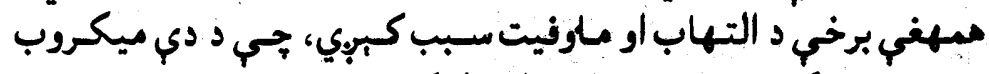

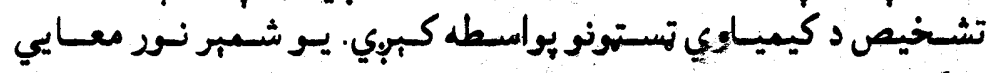

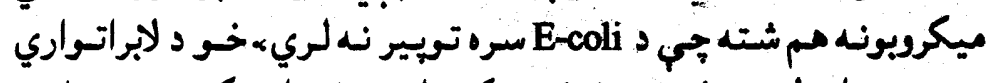

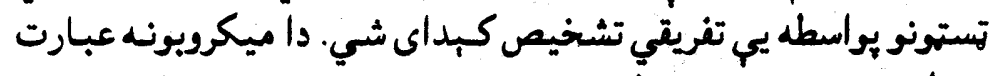
دي له Atypic coliform خُخهن. مورفولوزي او نلوين: Escherichia Coli

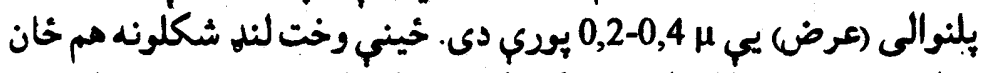

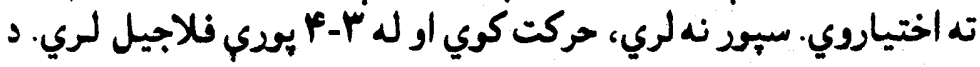

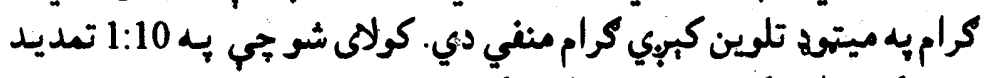

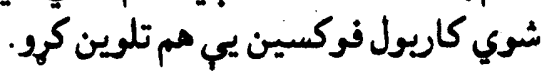

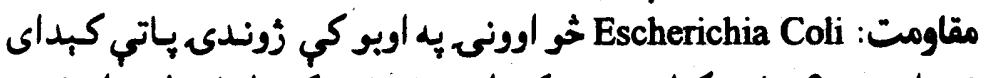

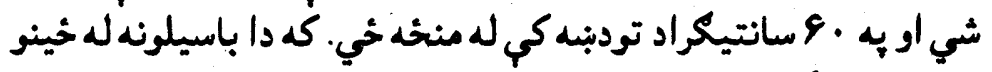

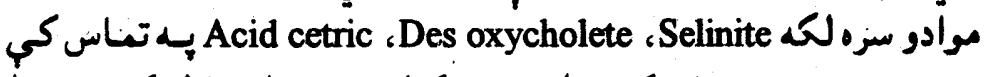

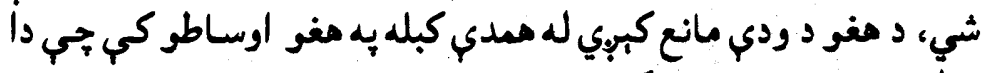

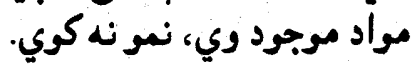

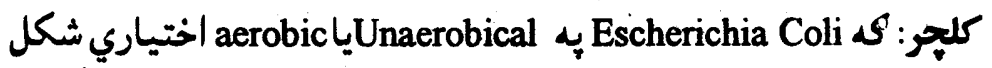

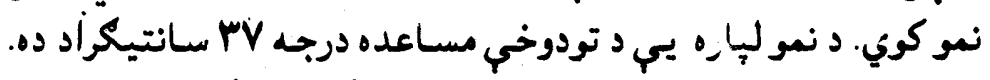

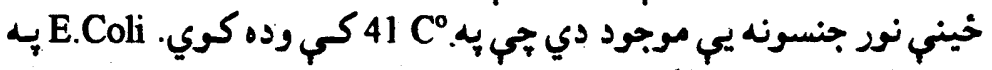

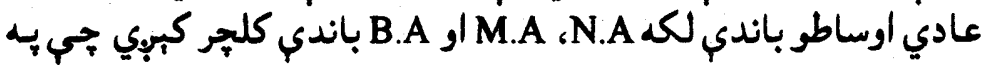

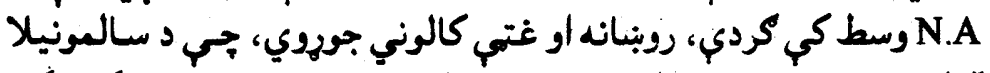

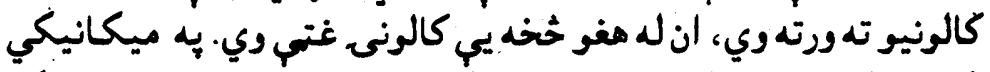

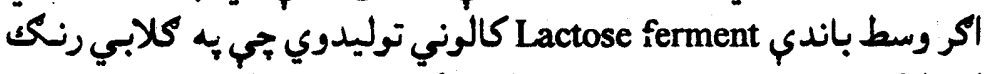

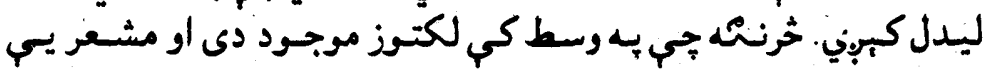


Neutral red

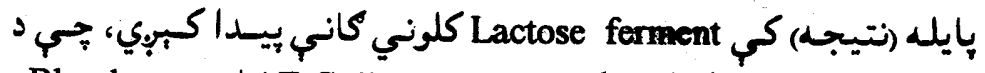
Blood كالوني كانو موجوديـت Lactose ferment

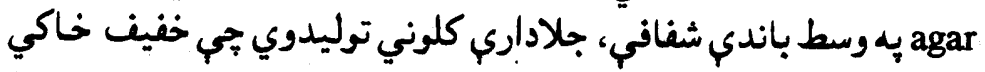
رنك لري.

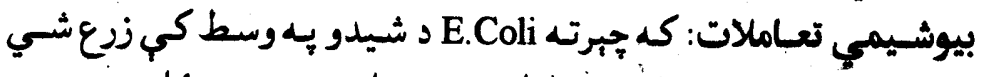

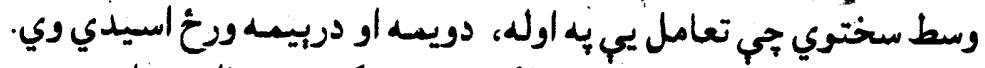

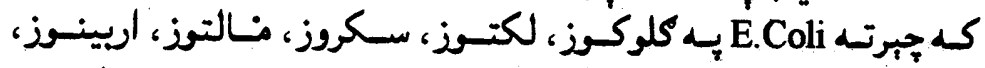

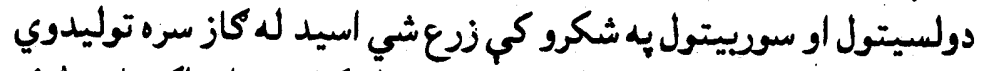

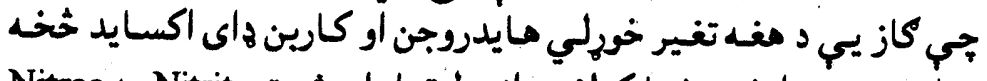

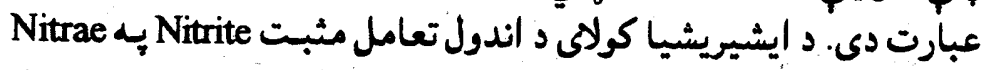

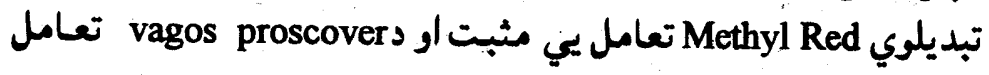

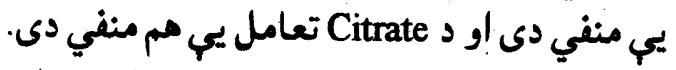

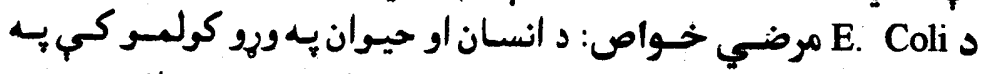

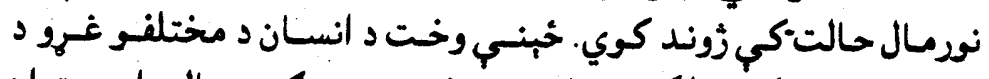

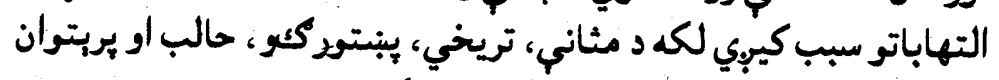

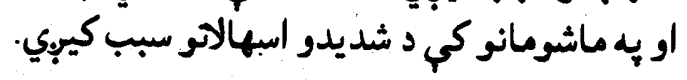

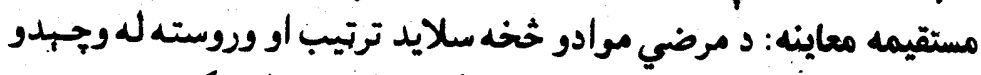

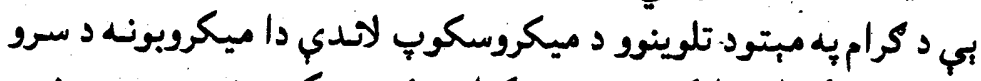

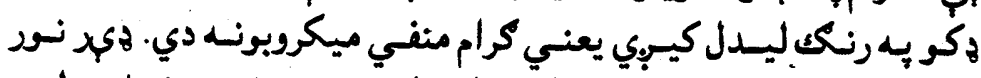

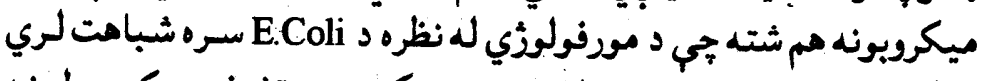

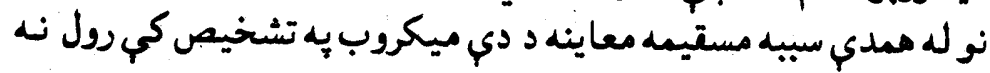
لري بلكي بايد كلجهر شي.

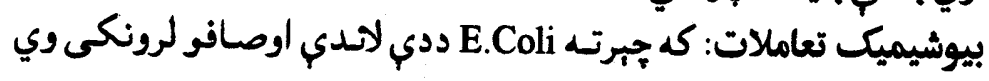

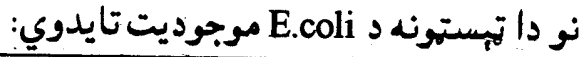

\begin{tabular}{|r|r|r|r|r|r|r|r|r|}
\hline \multirow{2}{*}{ E.Coli } & Tst & Indo & Citrate & M12 & VP & Gelatin & Gas & Acid \\
\cline { 2 - 9 } & $\mathrm{y} / \mathrm{y}$ & + & - & + & - & + & + & + \\
\hline
\end{tabular}

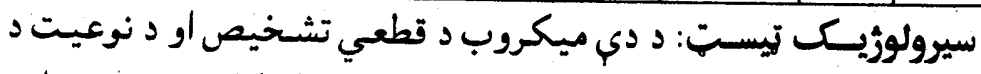

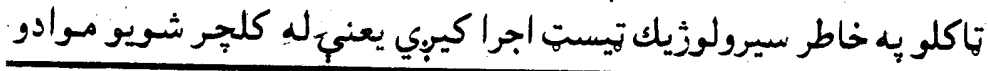




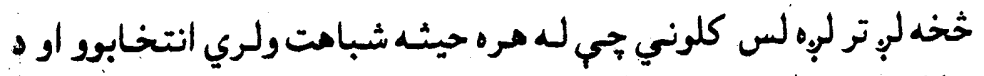

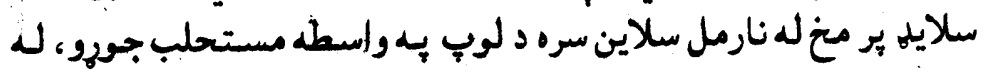

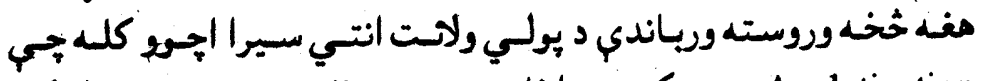
Agglutination

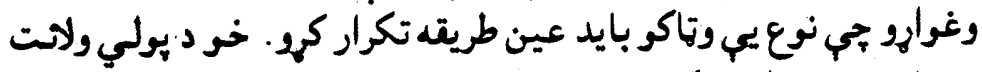

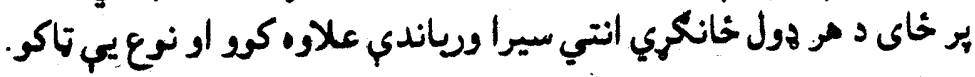

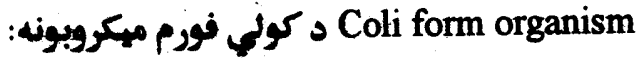

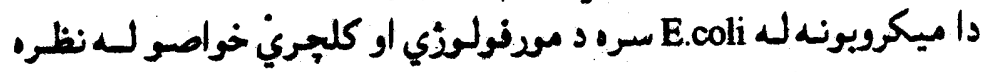

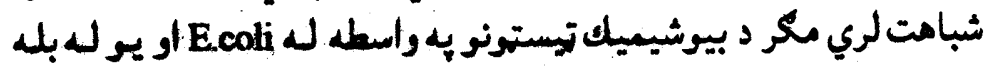
تفريقي تشخيص كيبني.

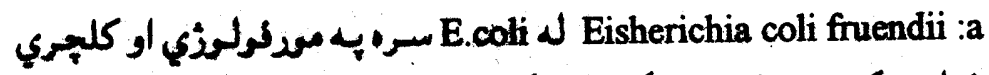

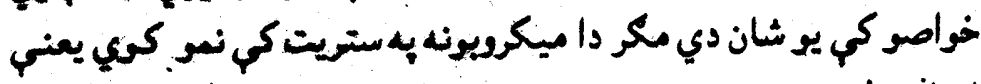
citrat ئ Aerobacter aerogen :b

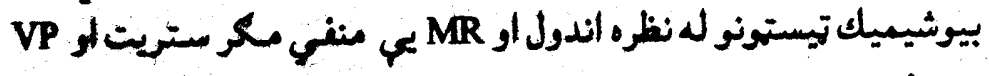

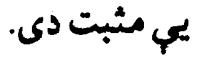

\begin{tabular}{|c|c|c|c|c|c|}
\hline Type of Bacteria & Indol & Citrote & MR & $\mathrm{VP}$ & $G c^{\circ}$ \\
\hline E.Fruendii & - & + & - & - & - \\
\hline Aerobacter Aerogen & - & + & - & + & - \\
\hline Aerobecter Colicea & - & - & - & - & + \\
\hline
\end{tabular}

:Para coli bacill Group

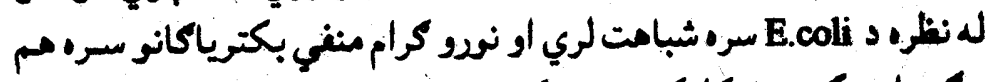

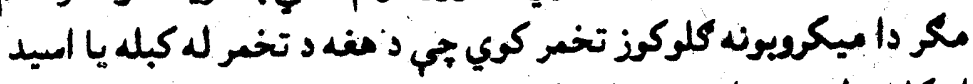

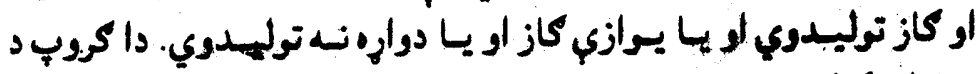

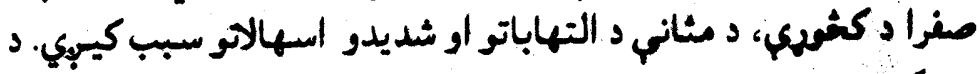

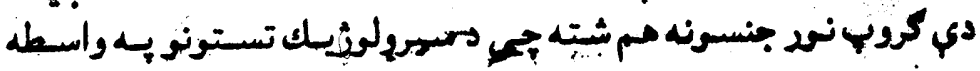
تفريخ تشخيص كيهي. 


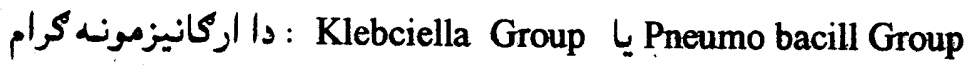

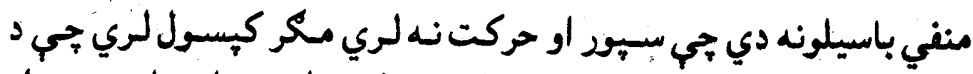

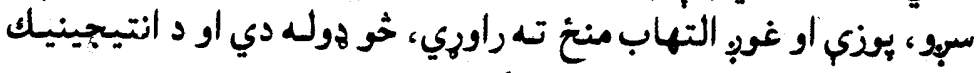

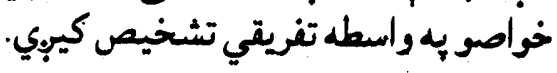

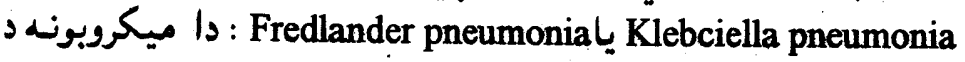

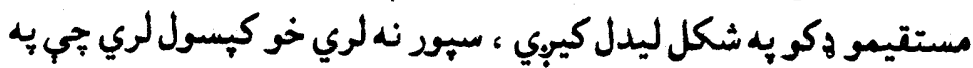

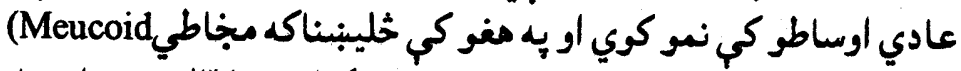

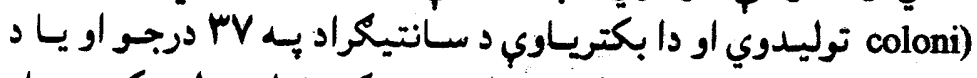

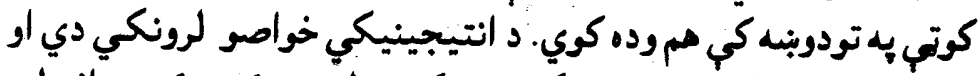

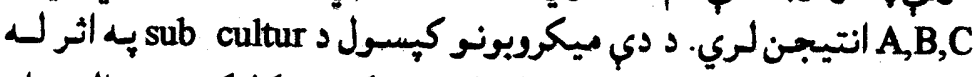

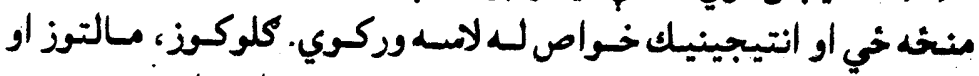

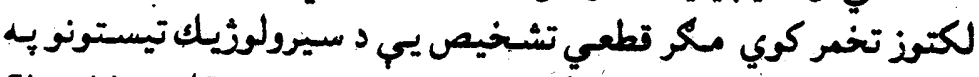

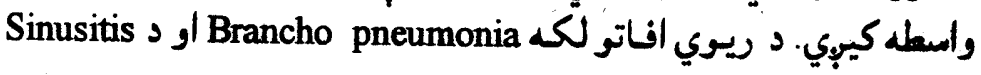
منغ ته راوري.

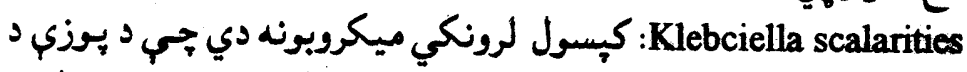

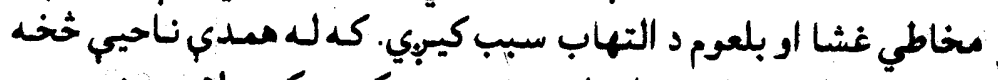

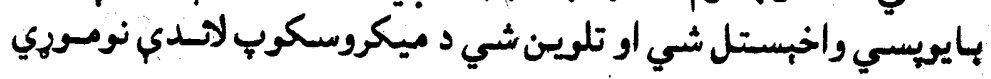

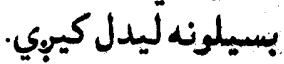
كlebciella Ozon.

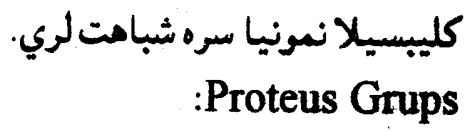

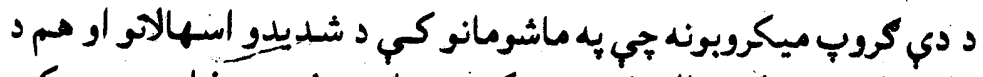

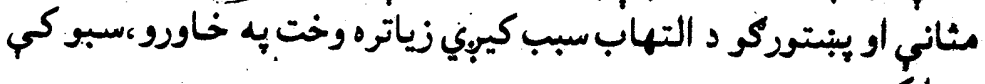
بيدا كبوي.

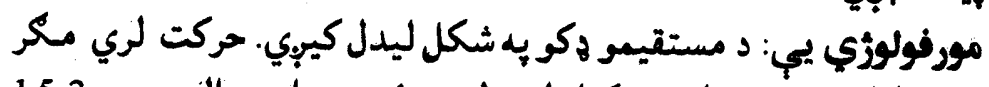

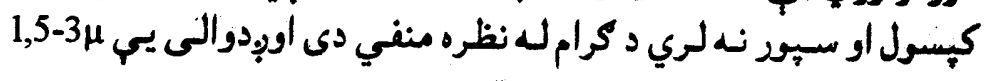

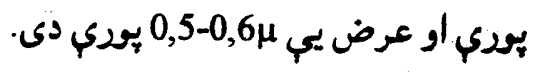




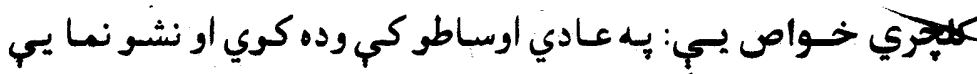

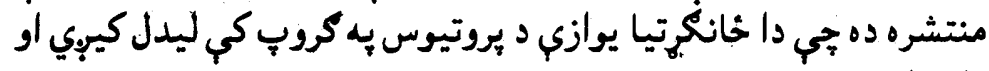

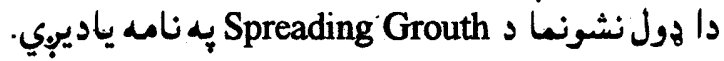

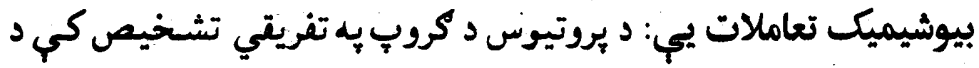

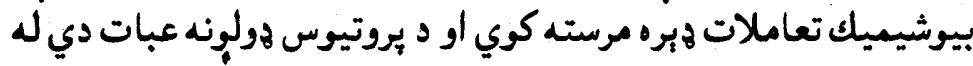

Proteus vulgaris, proteus mirabolis, proteus morganii

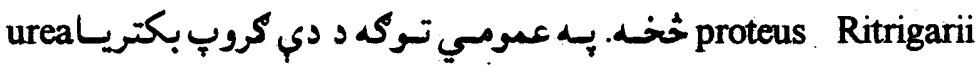

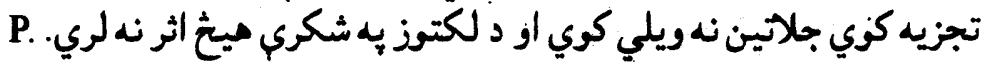

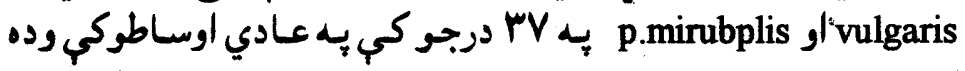

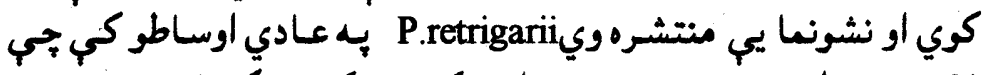

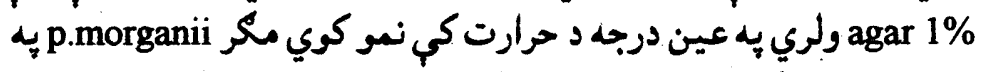

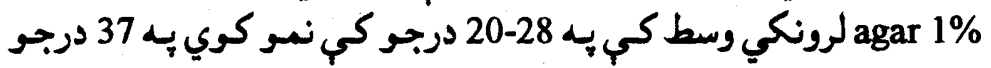

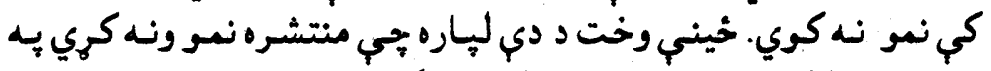

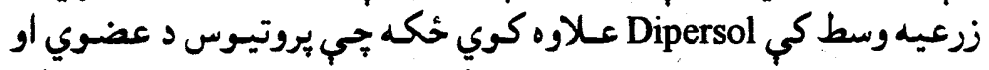

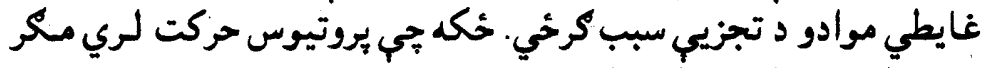

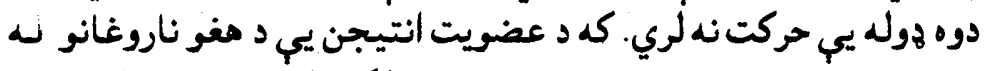

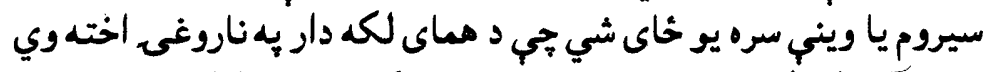

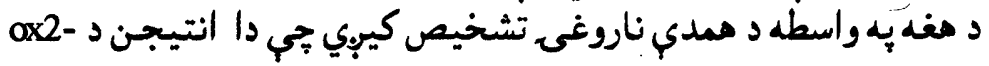
لإئ ox 19-oxk

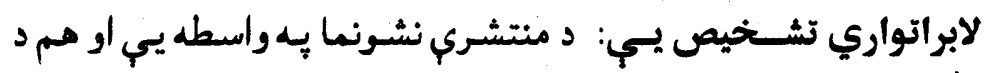

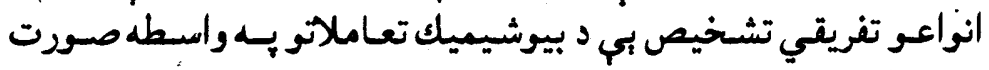

\begin{tabular}{|l|c|c|c|c|}
\hline $\begin{array}{l}\text { Type of chemical } \\
\text { meterial }\end{array}$ & $\begin{array}{c}\text { Proteus } \\
\text { vulgaris }\end{array}$ & $\begin{array}{c}\text { Proteus } \\
\text { mirabialis }\end{array}$ & $\begin{array}{l}\text { Proteu } \\
\text { smorgarii }\end{array}$ & $\begin{array}{l}\text { Preteus } \\
\text { Retri garii }\end{array}$ \\
\hline Lactose & - & - & - & - \\
\hline Saccharose & Acid+Gas & +- & +- & +- \\
\hline Manito! & - & - & - & Acid+Gas \\
\hline Indol. & + & - & + & + \\
\hline MR. & + & & + & + \\
\hline V.P. & - & ++ & - & + \\
\hline Urea. & + & + & + & + \\
\hline
\end{tabular}




\section{د وجكى يا سلمونيلا تايفايد بسيل}

\section{SALMONELLA TYPHOID BACILLI}

مورفولوزي او تلوين يسمي: د سلمرنيلا بسيل لجي د وجكى (محرقني)

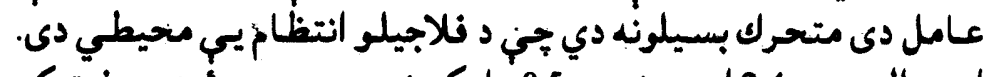

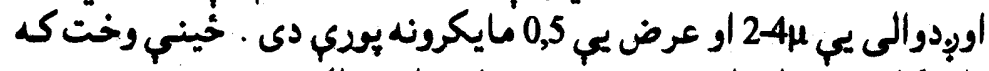

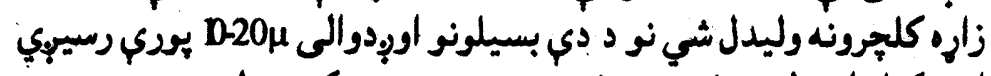

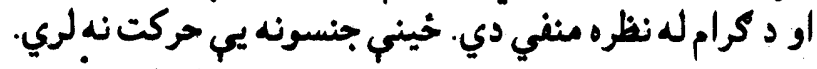

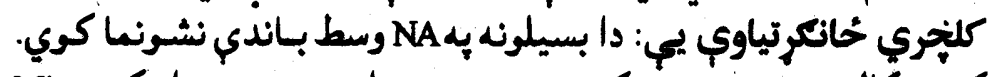

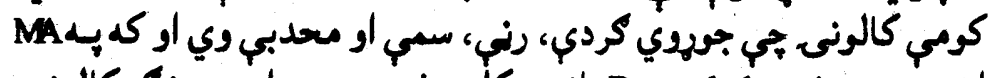

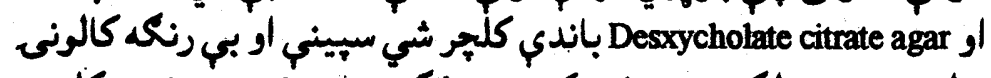

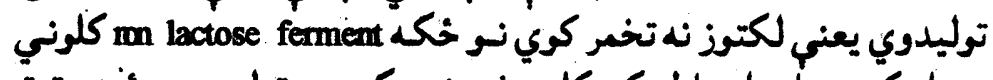

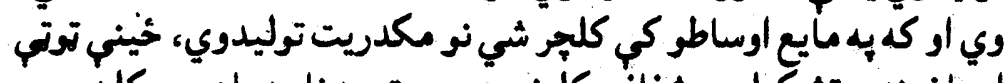

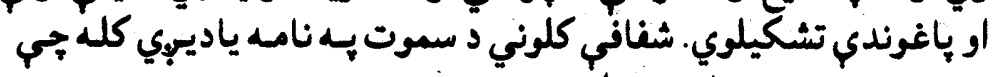

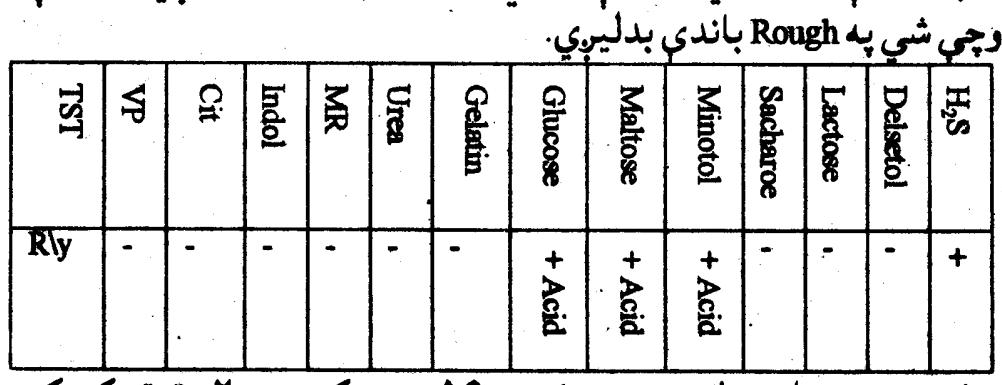

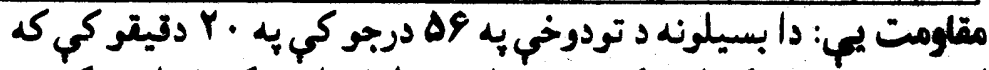

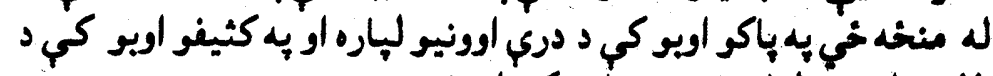

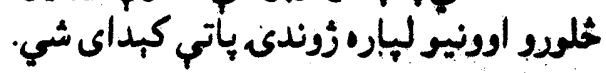

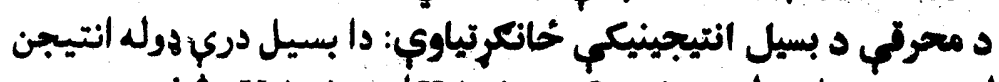

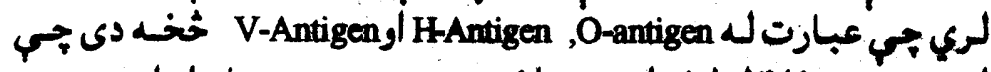

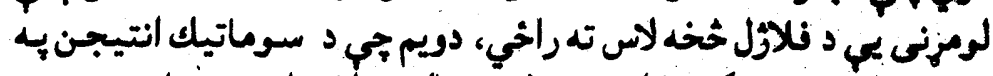

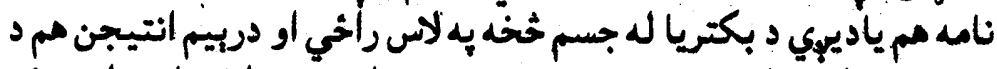

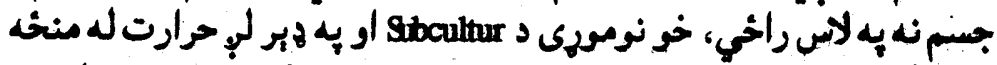

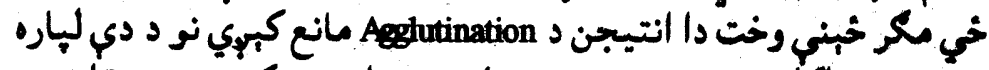
جي حقيفي اكلورتينيشن ووينو مستحلب ته حرارت وركور جيم د انتيجن 


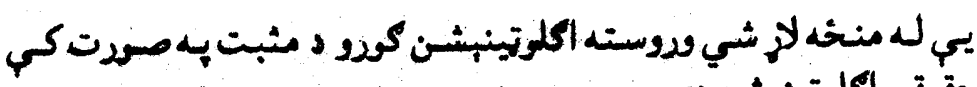
حقيقي اكلوتينهشن دئ.

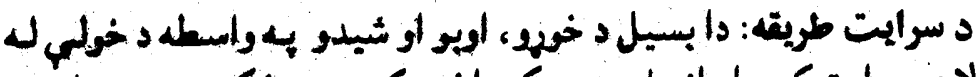

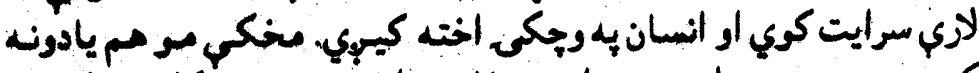

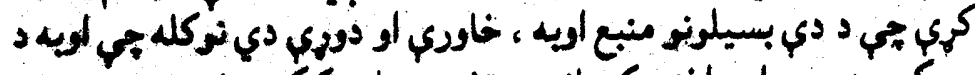

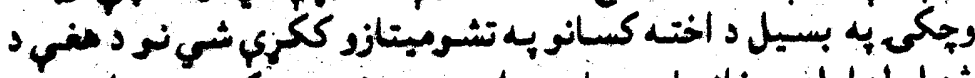

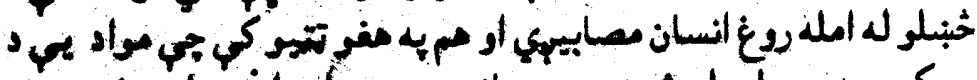

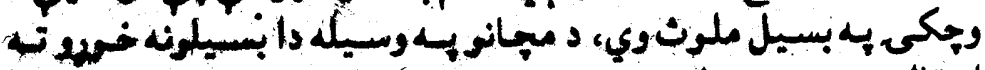

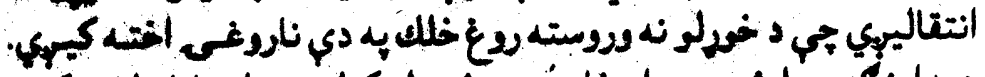

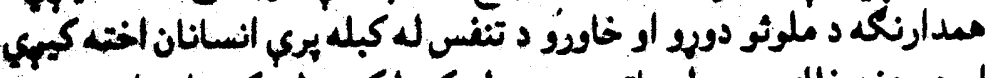

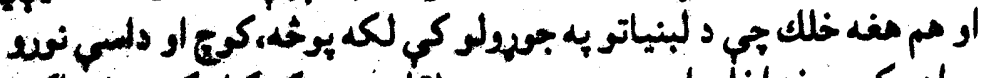

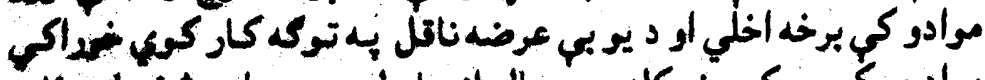

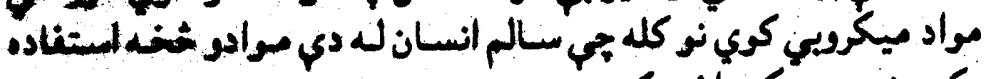
وكهي نو به وجكمى أخته كيبري.

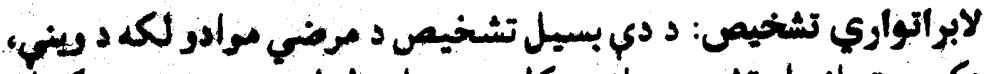

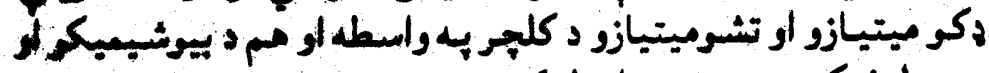
سبرو لوزيكو تيستونو يه واسطه كهيوي.

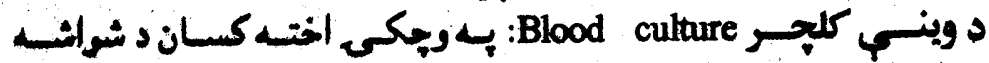

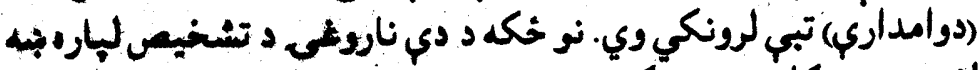

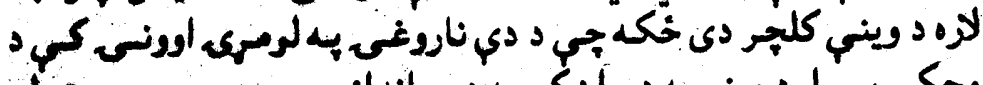

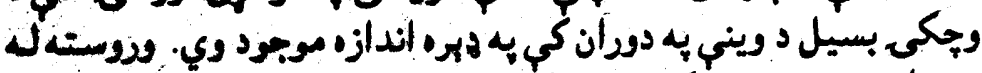

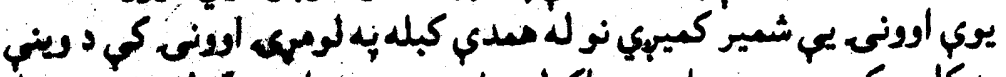

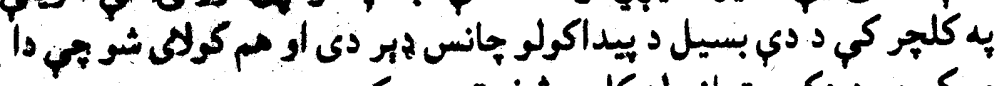

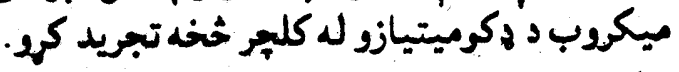

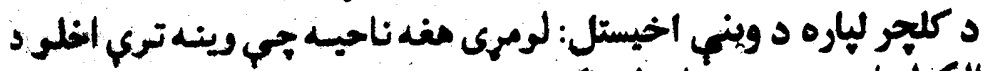

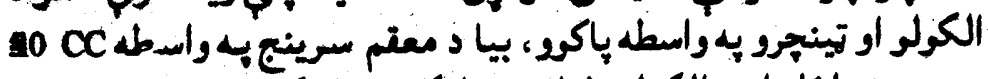

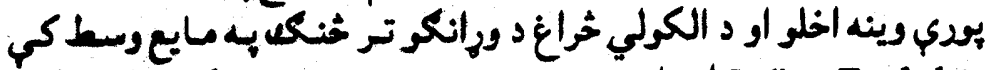

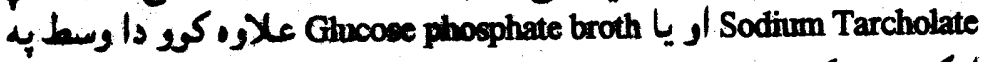

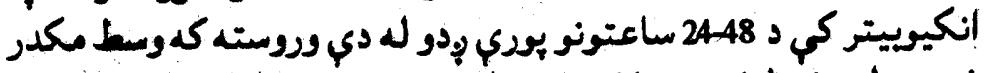

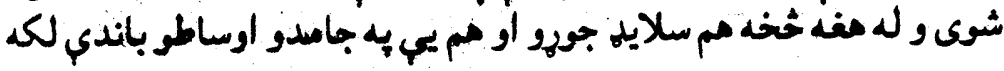




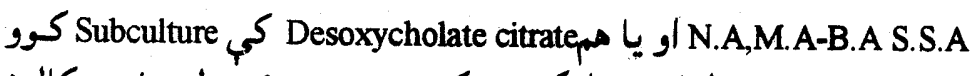
او د بورتنى مودي لهياره يب انكوييت كوو وروسته هغه توليد شوي كالوني

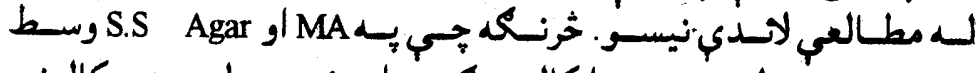
N.L.F.coloni

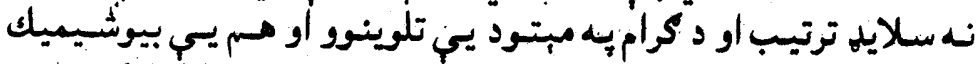

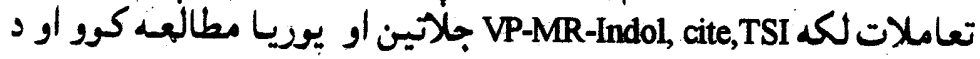

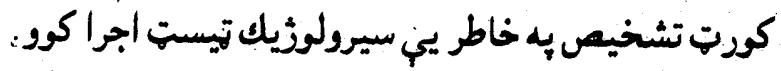
شوي :Stool culture

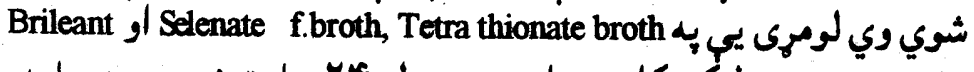
Green broth

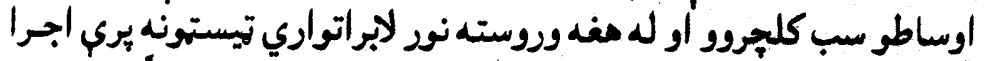

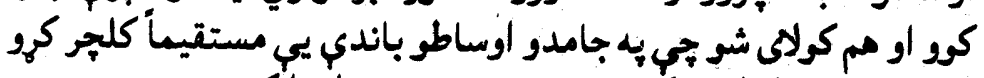

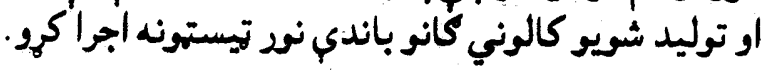
Urine culture

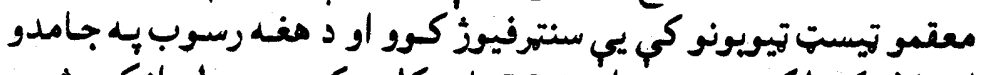

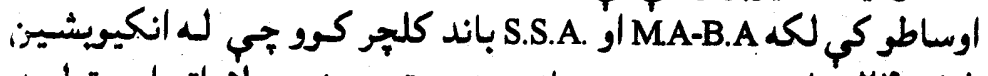

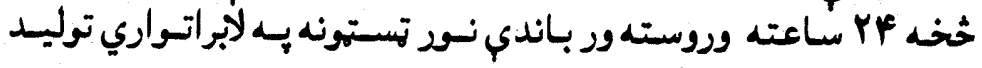

$$
\text { شوركلوني باندي اجراكوو. }
$$

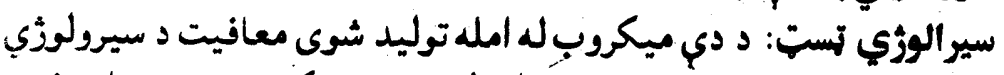

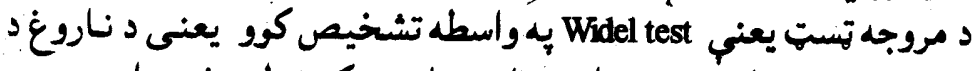

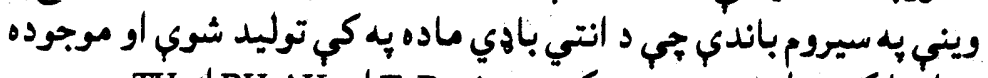

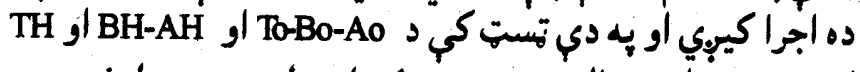

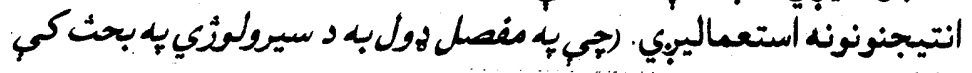

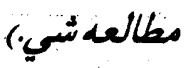

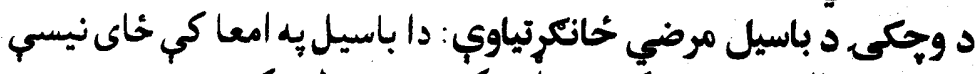

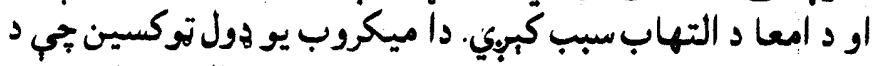

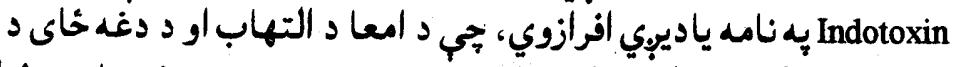

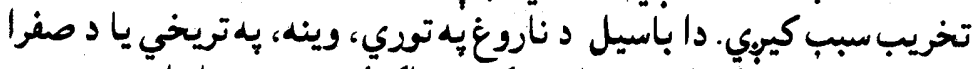

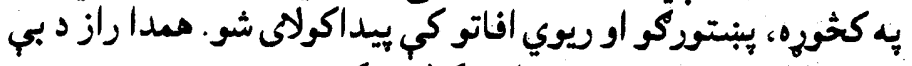

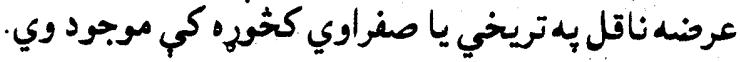




\section{Dysentry Group د ديزانتري كروب}

مورفولوزي:

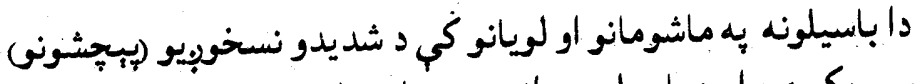

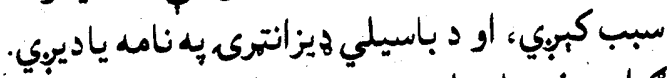

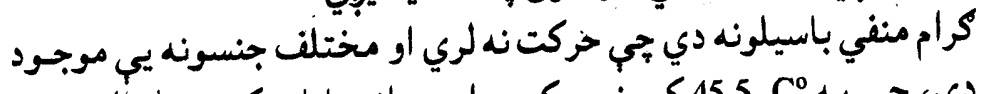

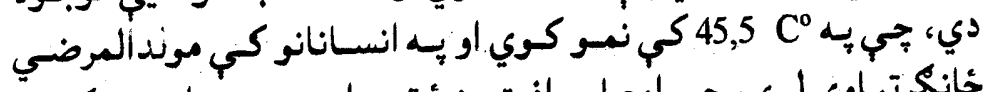

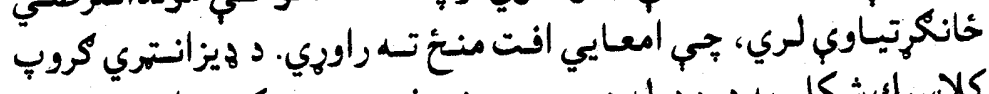

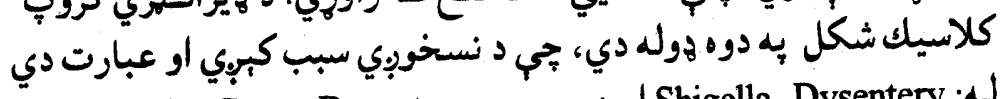

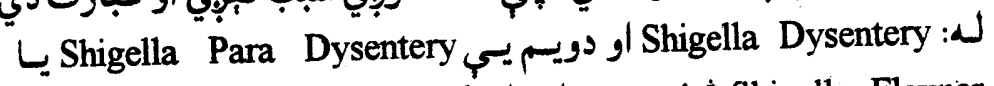
Shigella Flexner

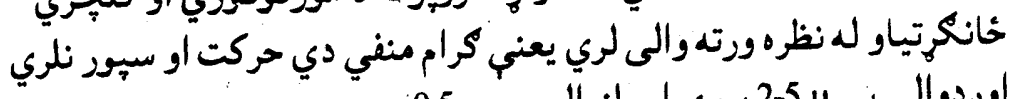

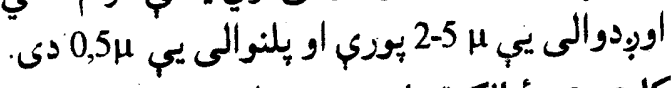

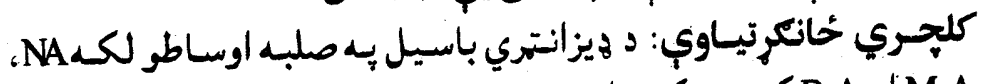

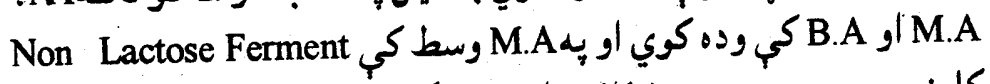

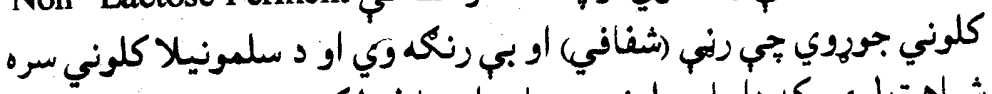

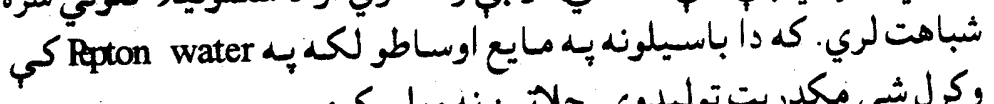

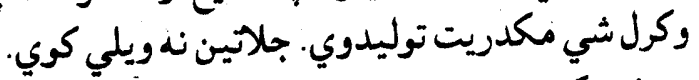

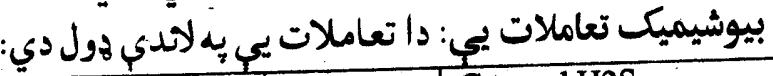

\begin{tabular}{|l|l|l|}
\hline Type of carbohydrate & Reaction & Gas and H2S \\
\hline Lactose & - & - \\
\hline Saccharose & - & - \\
\hline Maltose & - & - \\
\hline Manitol & - & - \\
\hline Dalcetol & - & - \\
\hline Glucose & $(+)$ Acid & - \\
\hline MR & - & - \\
\hline Indol & - & - \\
\hline Urea & - & - \\
\hline Gelatin & - & - \\
\hline Motility & - & - \\
\hline TS I & RY & - \\
\hline
\end{tabular}


د ديزانتري باسيل انتي جينيكي خحانكرتيـاوي: S higella Flexner

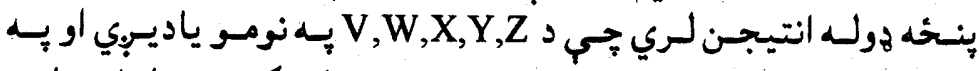

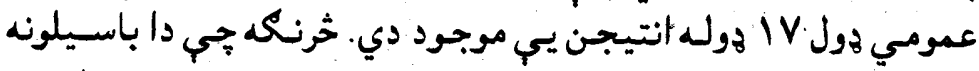

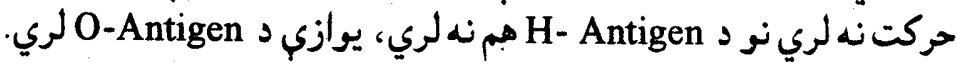

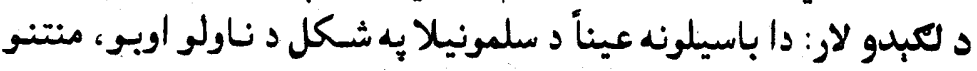

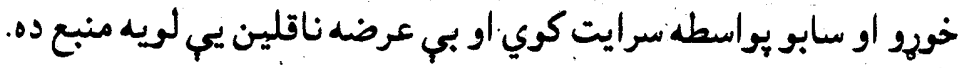

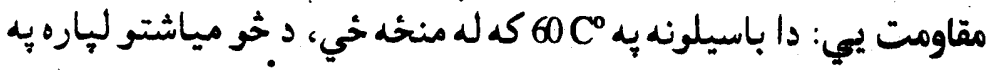

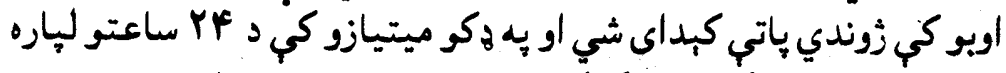

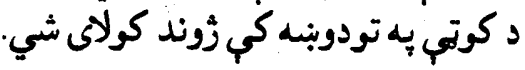

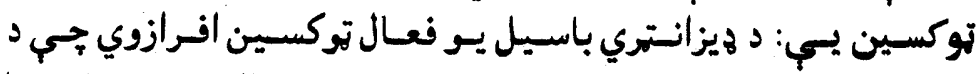
Sxotoxin

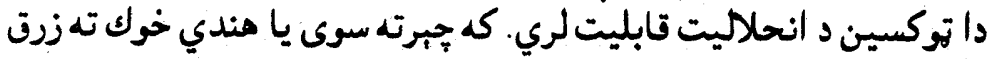

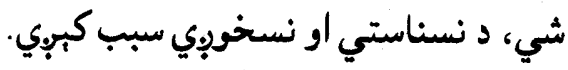

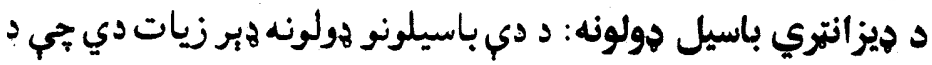

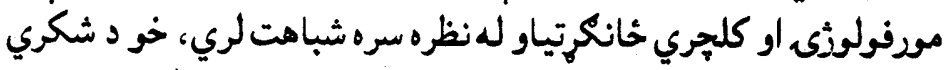

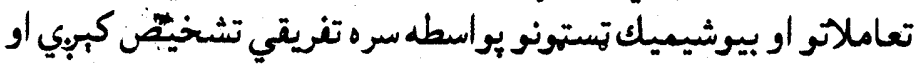

Shigella Sonnei

Shigella Boydie

Shigella Shimets

Shigella Shiga

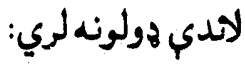

Para Shigella

Shigella Disper

Alkalesence

خيني نور ميكروبونه مم شته جي د نسناستي او نسخوبِي سبب كبوبي جي

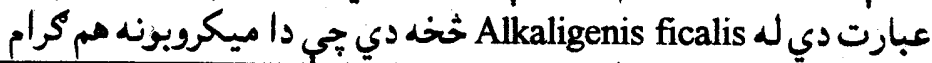

\begin{tabular}{|c|c|c|c|}
\hline \multicolumn{4}{|c|}{ د ناروغى توليدونكي شكيلا خولونه } \\
\hline $\begin{array}{l}\text { Ornithine } \\
\text { Decarboxylase }\end{array}$ & Mannitol & كروبِاو تَايب & نوم \\
\hline- & - & A & S. Dysenteriae \\
\hline- & + & B & S. Flexneri \\
\hline- & + & $\mathrm{C}$ & S. Boydii \\
\hline+ & + & D & S. Sonnei \\
\hline
\end{tabular}

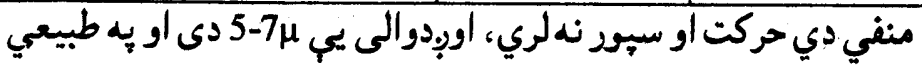

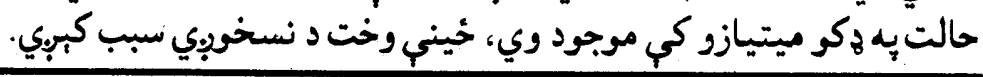


د ديزانتري باسيل مزضي خحانكرتياوب: د نسخوبري او د امعل د التهاب

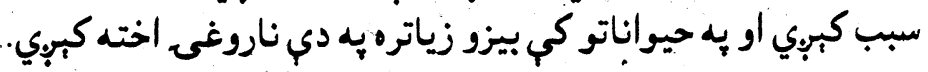

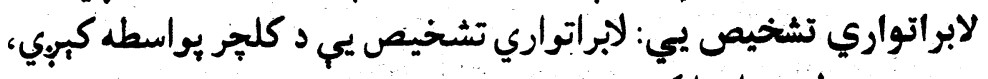

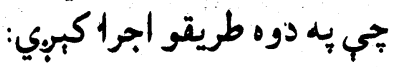

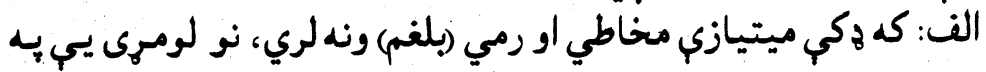
Selenite F Broth

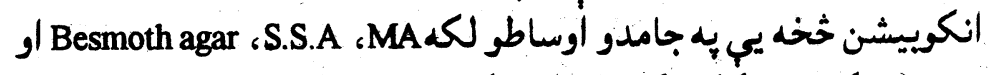
S.D.C.A

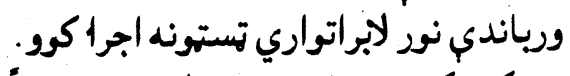

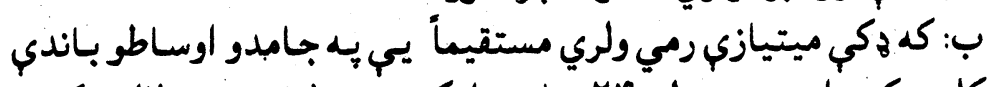

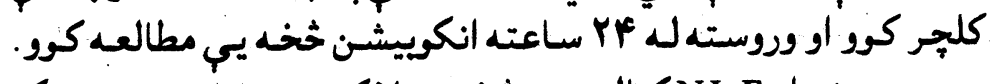

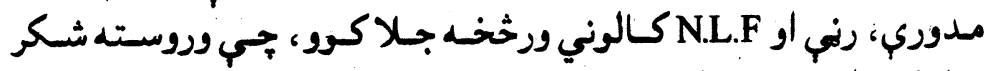

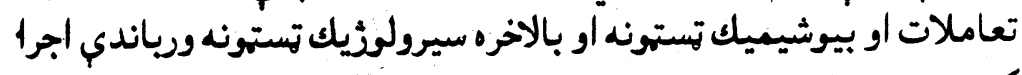
كوو. تعامل

\section{Vibriose}

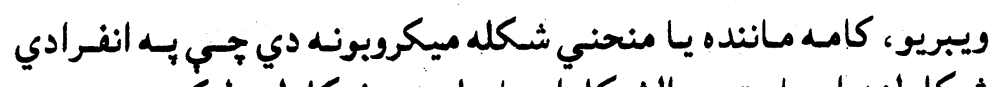

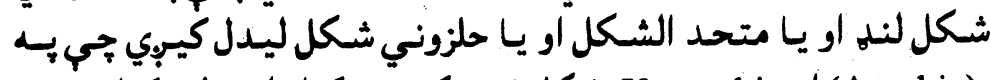

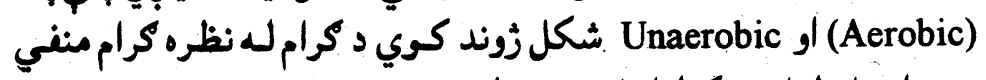
دي د انسان لياره د كولرا ناروغي توليد وي.

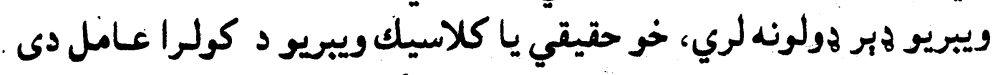

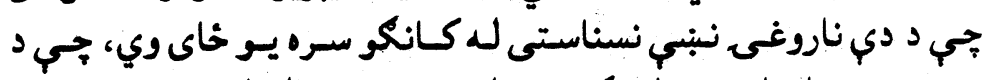

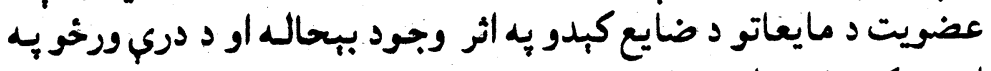

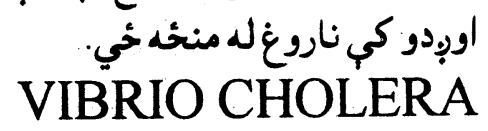

مورفولوزي او تلويني خانكرتياوي.يجي:

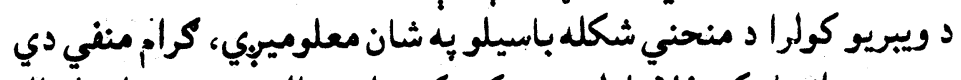

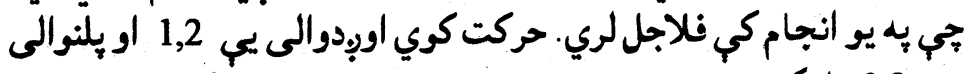
يبي 0,3 مايكرونو ته رسيبي. 


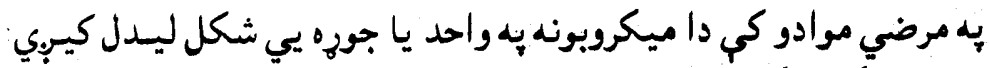

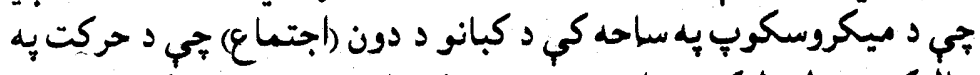

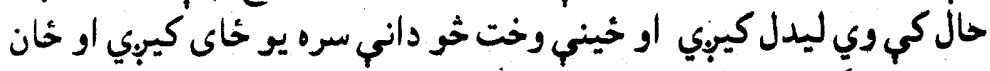

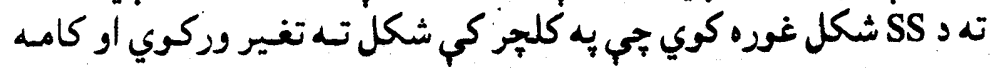

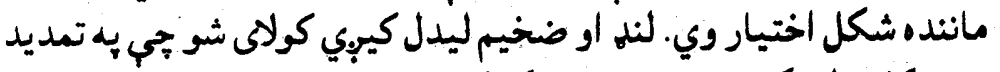

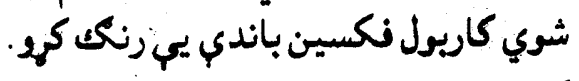

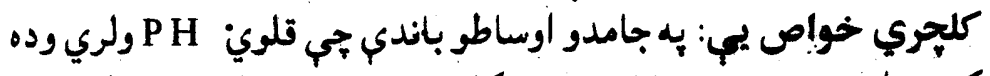

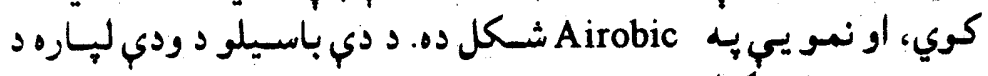

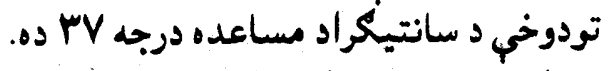

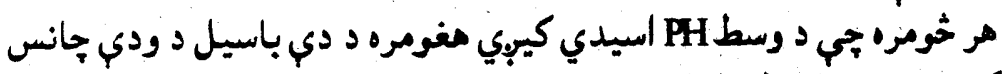

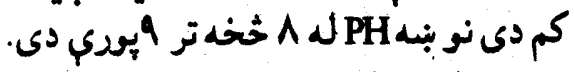

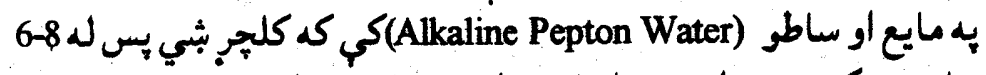

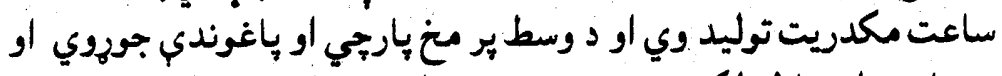

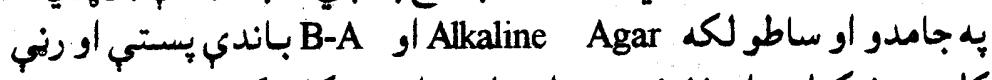

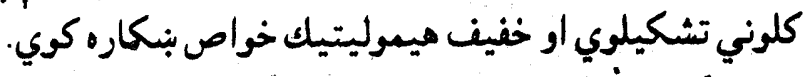

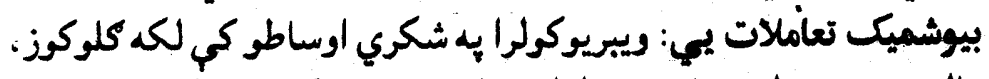

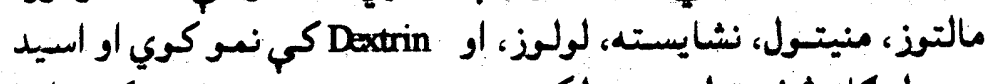

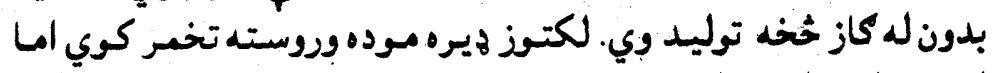
اربينوز او دوليستول نه تخمر كوي.

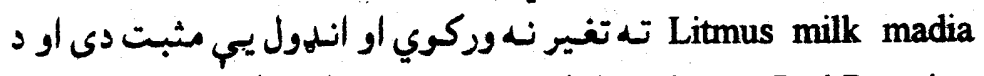
Cholera Red Reaction

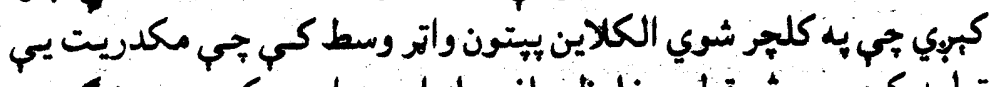

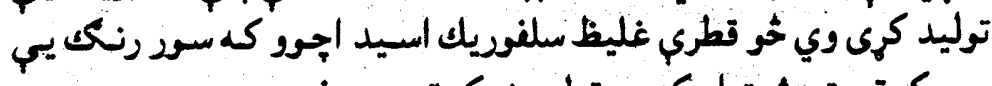

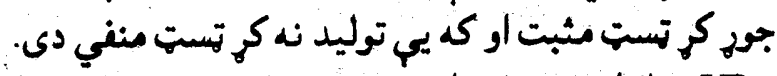

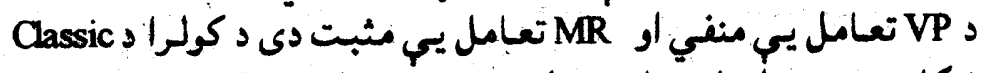

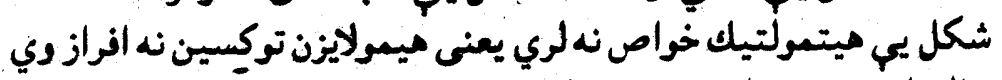

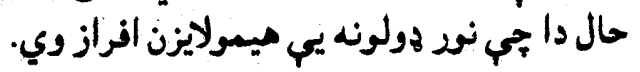

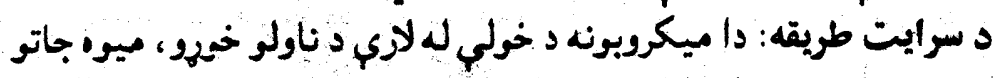
او سبزيجاتو د خوزيو به داثر سرايت كوني. 


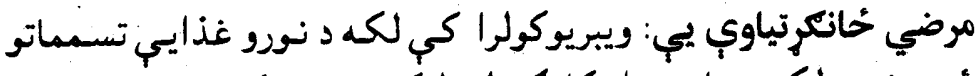

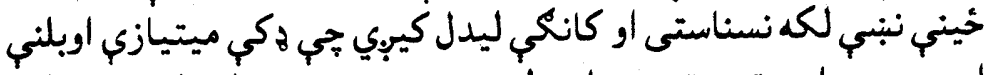

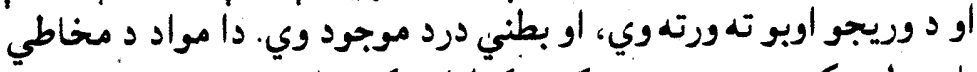

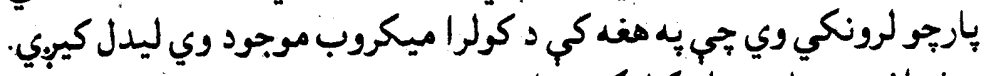

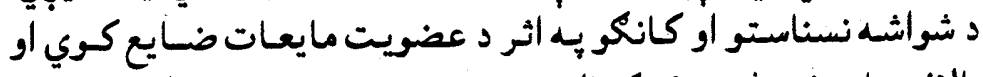

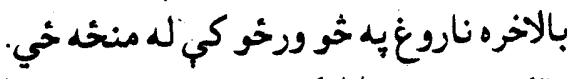

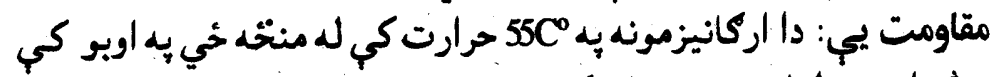

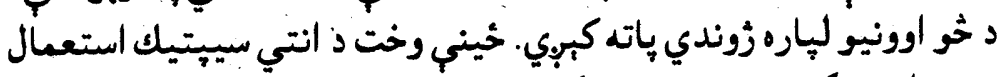

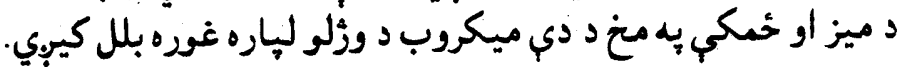

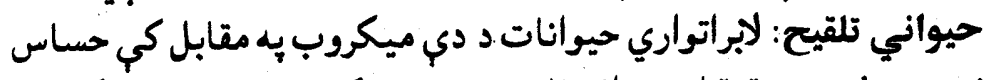

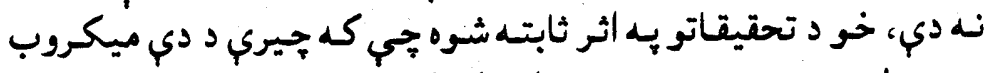

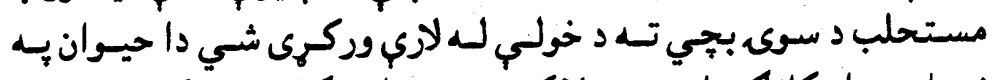

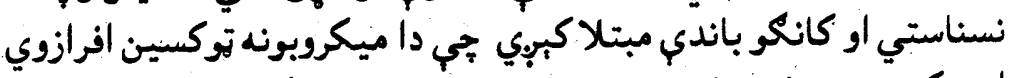

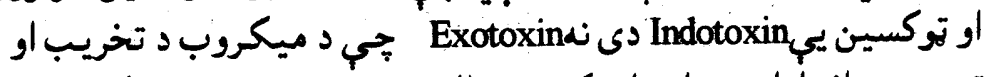

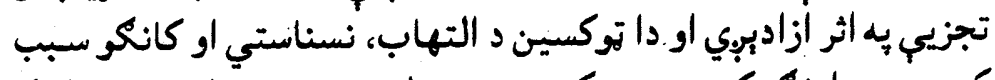

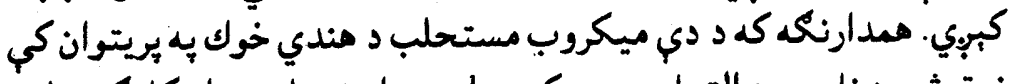

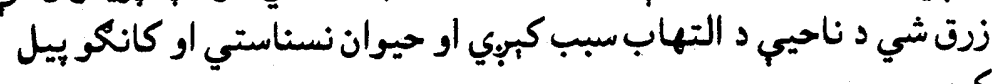
كوي.

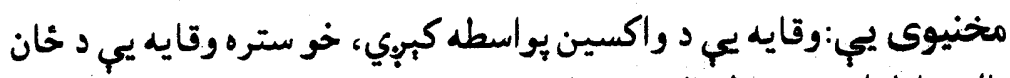

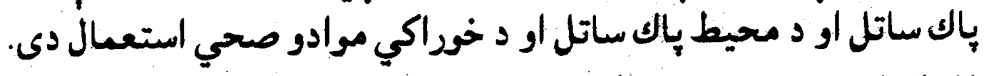

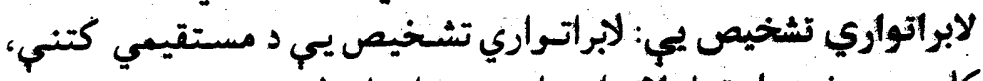

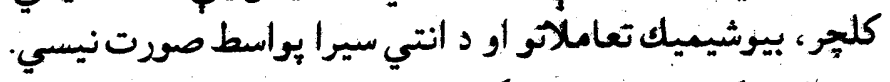

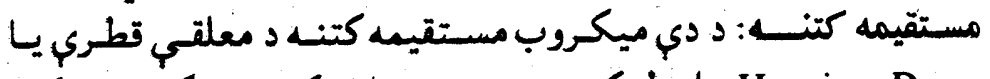
Hanging Drop

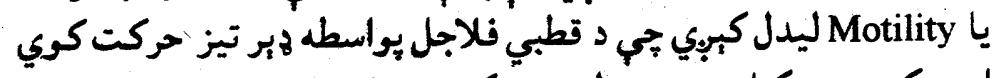

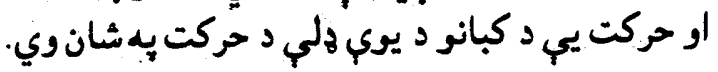

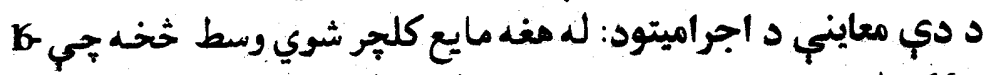

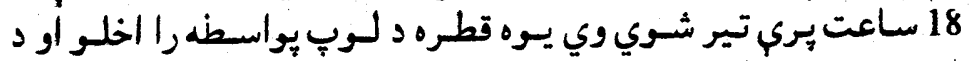




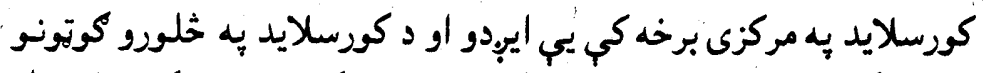

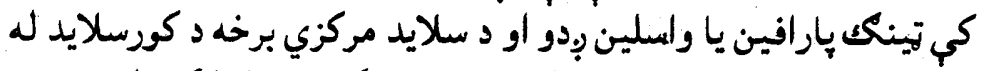

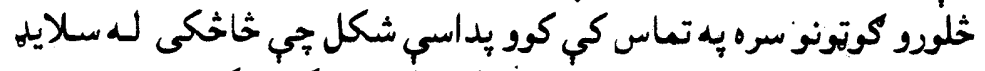

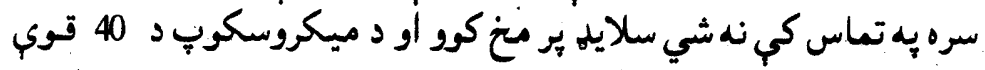
يواسطة يم حركت كمرو.

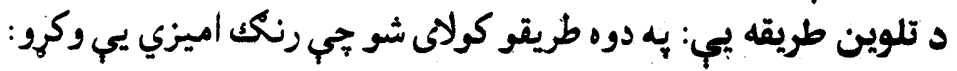

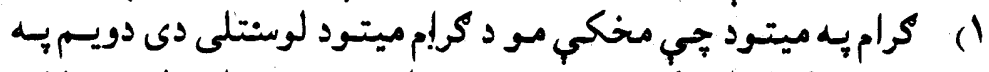

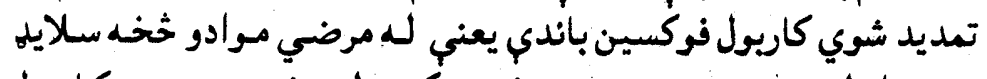

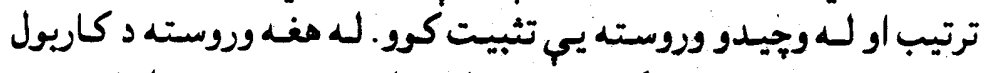

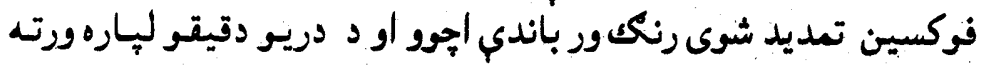

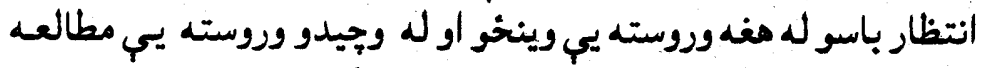

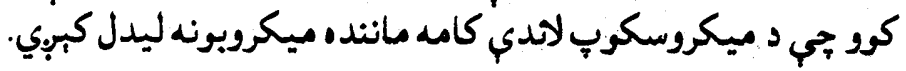

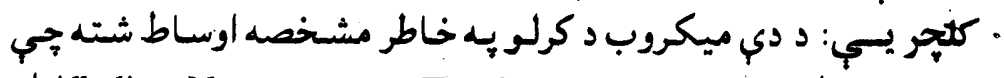

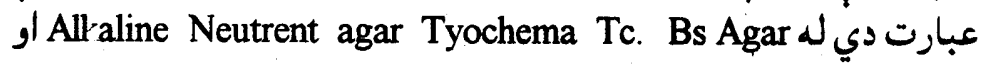
الكلاين يستون واتير دى. لي.

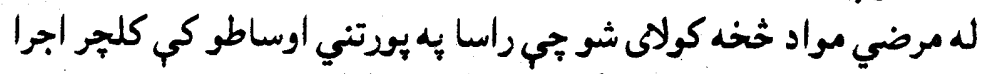

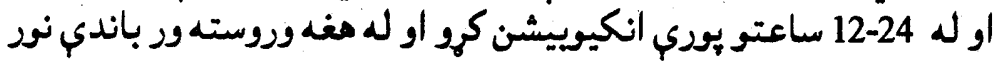

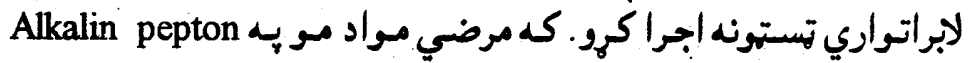

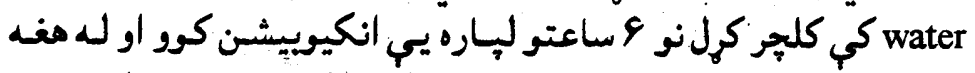

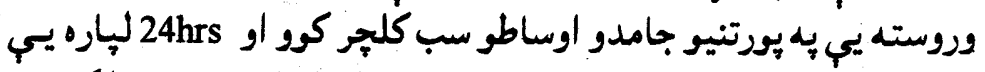

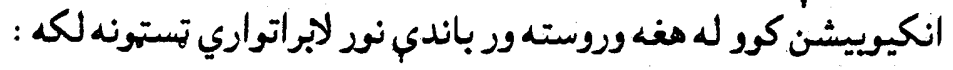

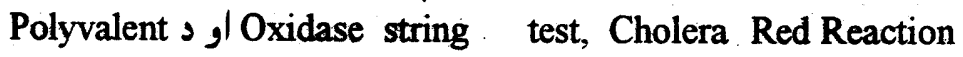

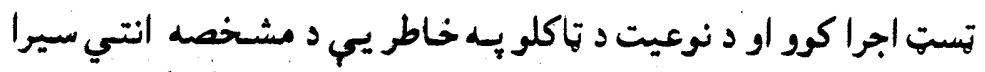

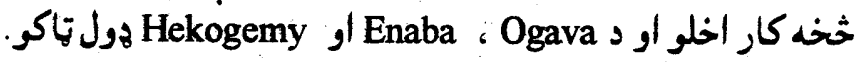

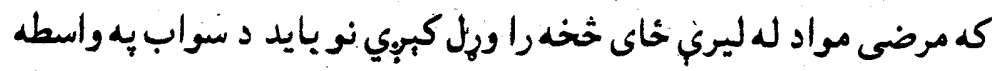

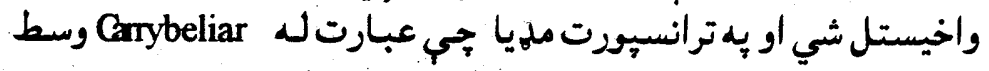

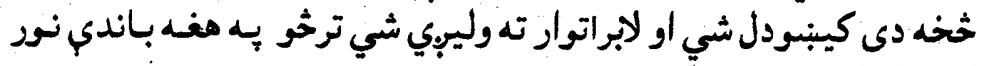
هالبراتواري تستنونه اجرا شي. 


\section{Aerobic Gram Positive spore Forming Bacilli}

\section{ايروبيك كرام مثبت سيورلرونكي باسيلونه}

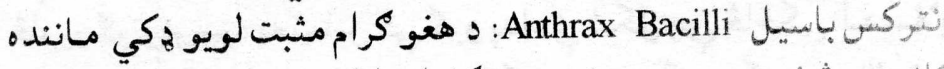

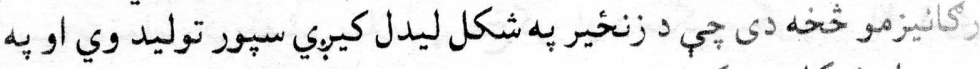

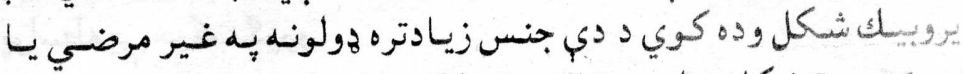

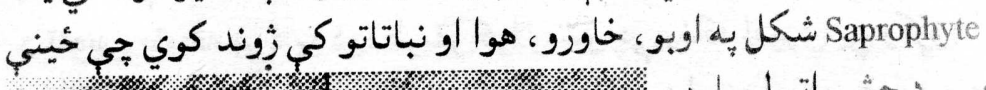

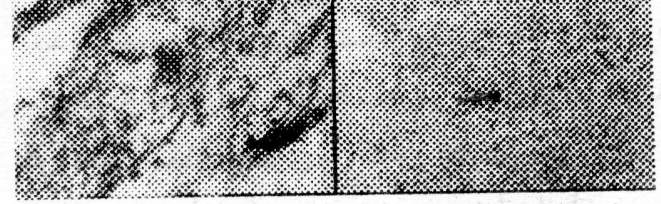

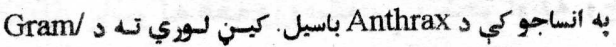

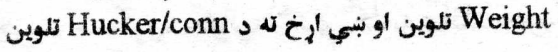

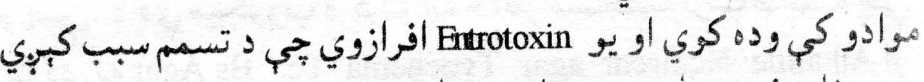

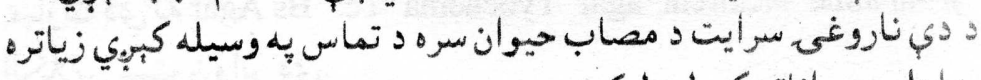

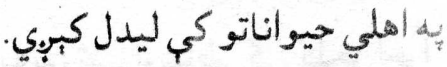

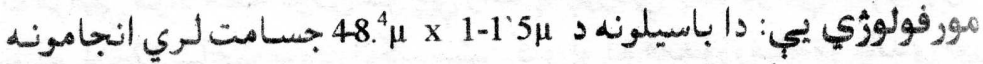

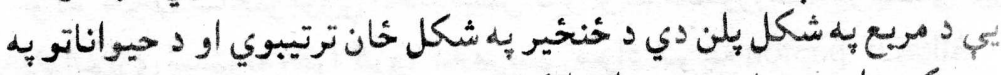

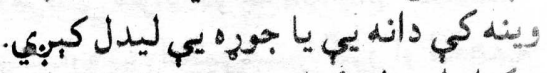

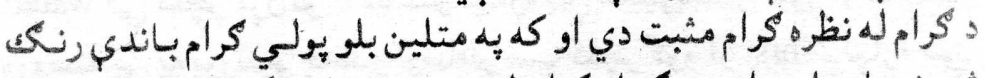

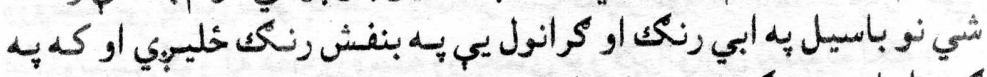

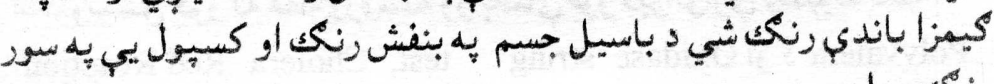

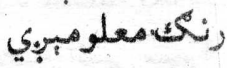
كلجري خُانكرتياوي يبي: د اباسيلونه Aerobic إو انتتياري ان ايروبيـك Facultative anaerobis

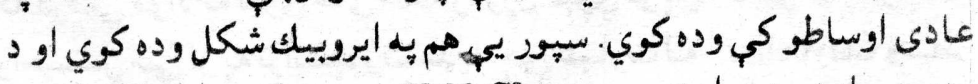

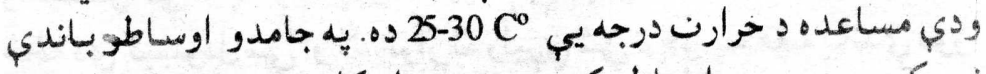

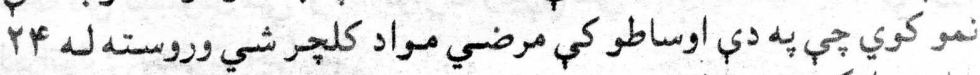

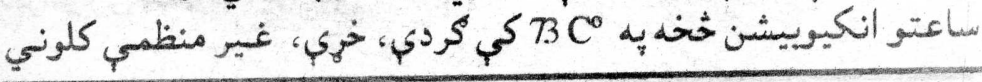




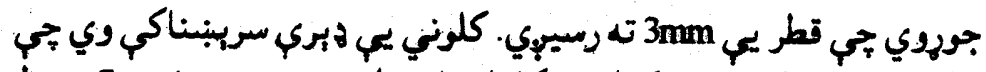

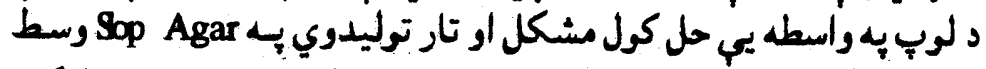

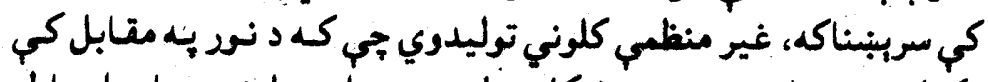

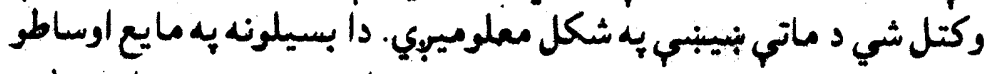

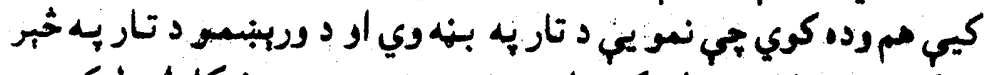

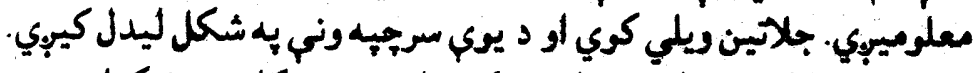

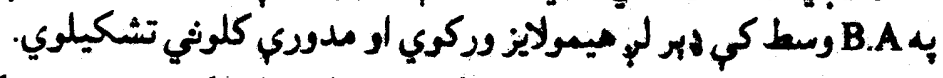

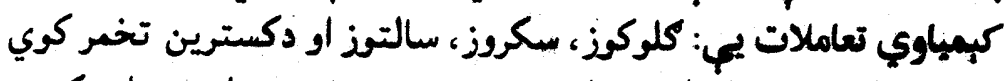

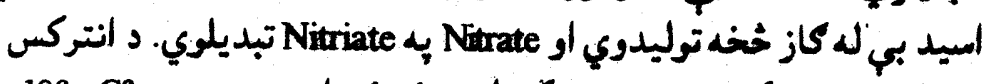

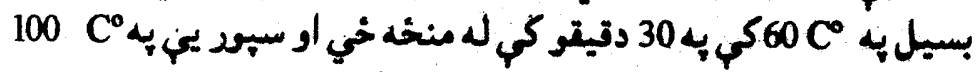

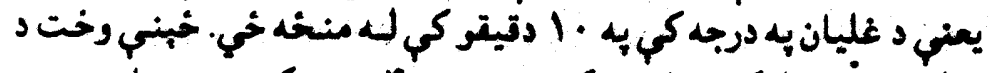

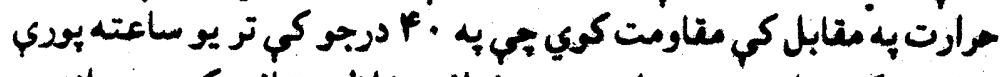

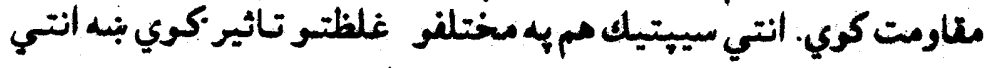

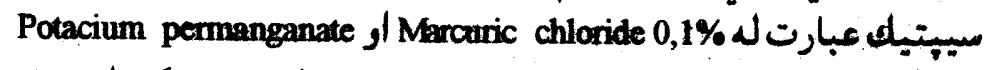

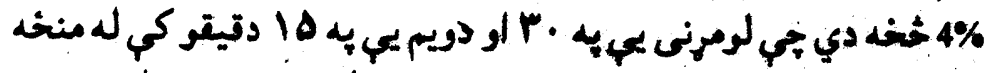

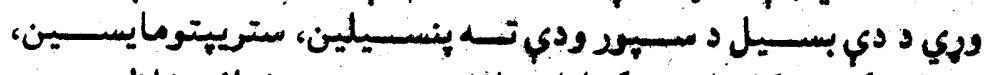

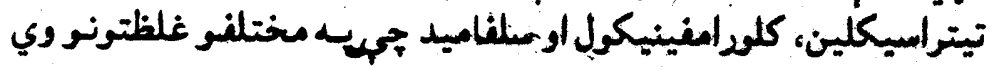
تونف وركوي.

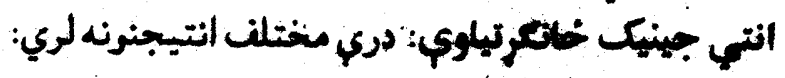
Antrax Toxin complex a : a 1 a

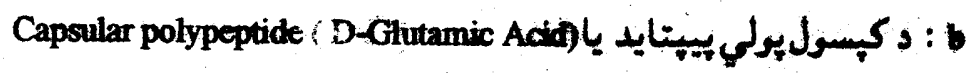

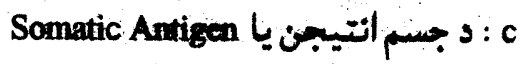

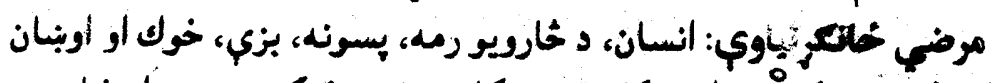

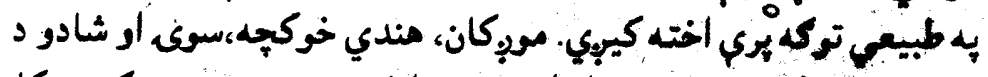
o

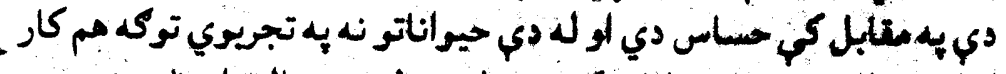

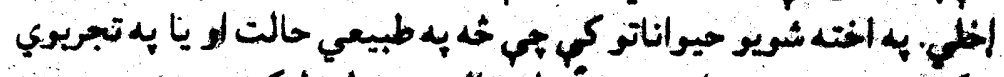

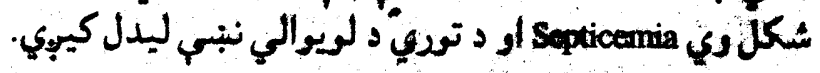


لابراتواري تشخيص يجي: كوم لابرتواري مبتودونه جي د انتركس د بسيل

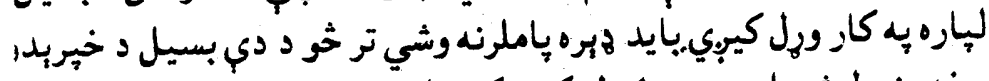

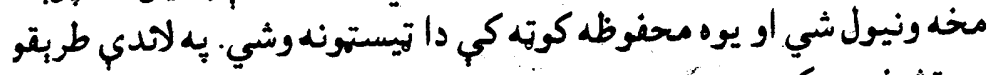
ني تشخيص كور:

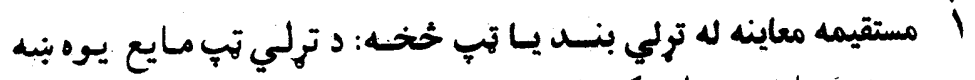

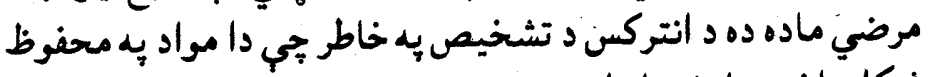

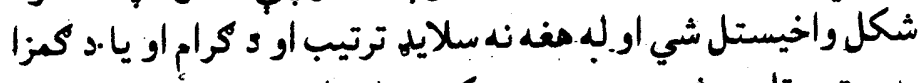

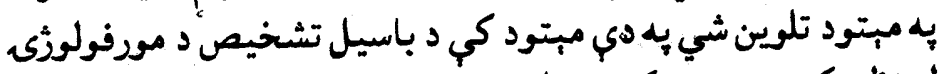

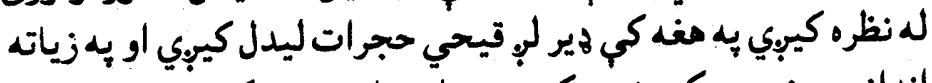

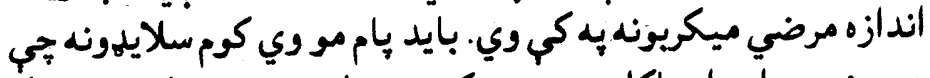

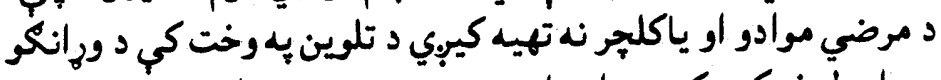

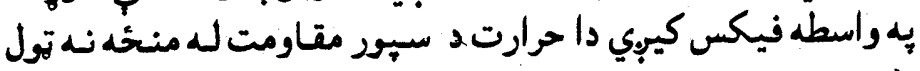

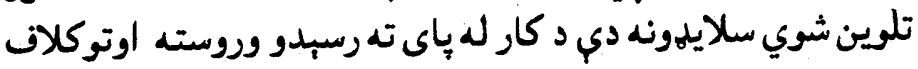
شي. r - كلِحر يجي: كولايى شو دا بسيلوند بِه مايع او جامدو اوساطو كي كلجِر

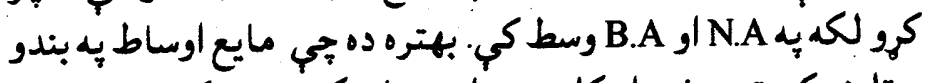

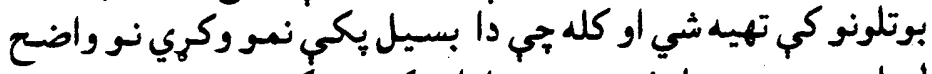

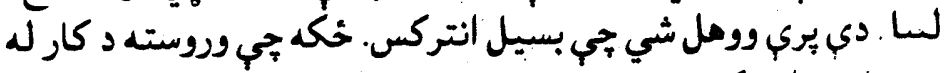

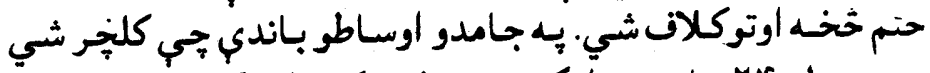

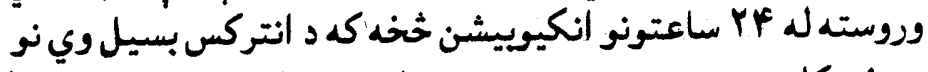

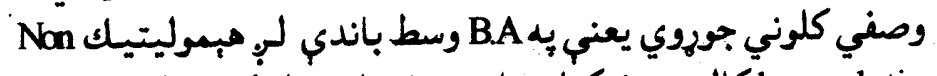

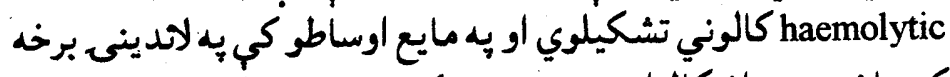

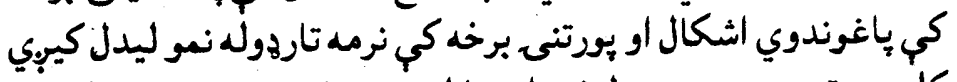

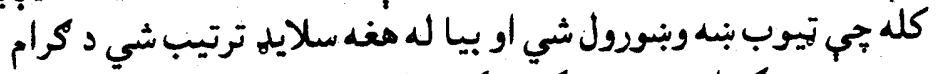

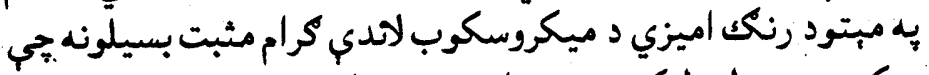

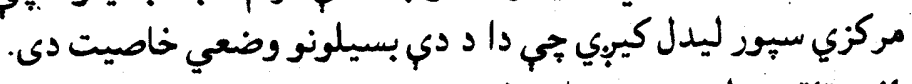

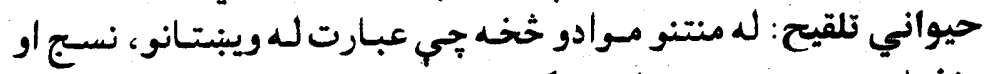

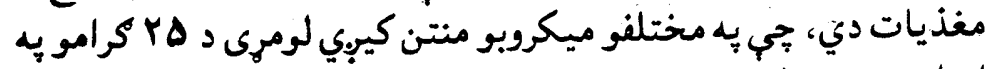

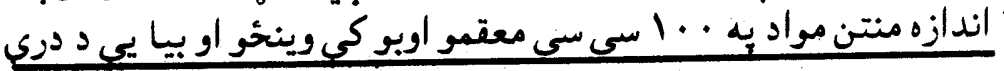




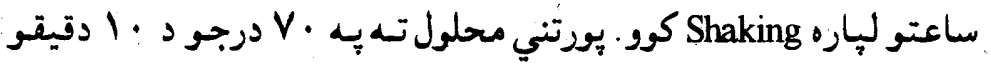

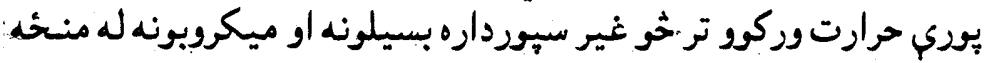

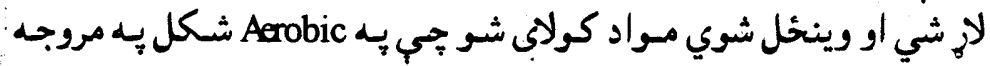

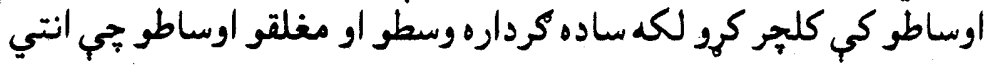

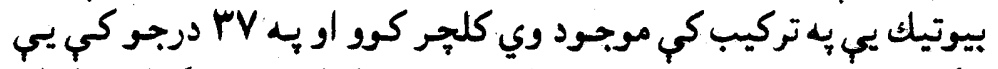

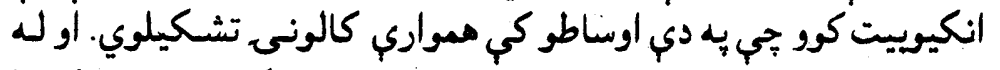

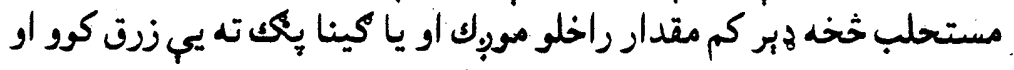

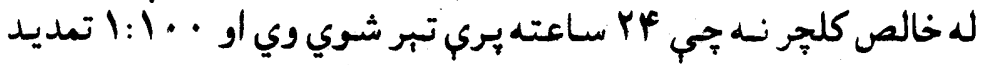

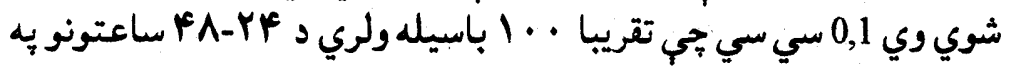

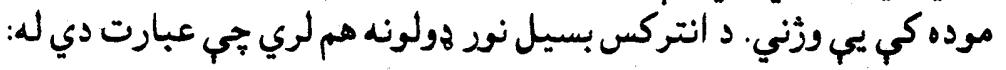
B. Stearothermophilus/B.Megatercium ،B.subtilis B.Cereus خخه. 


\section{كور او د كور هيلب}

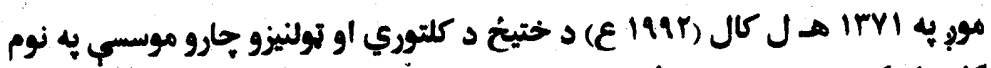

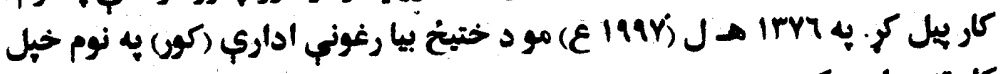
كار ته دوام وركي.

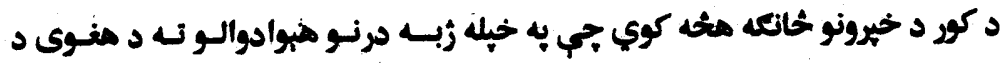

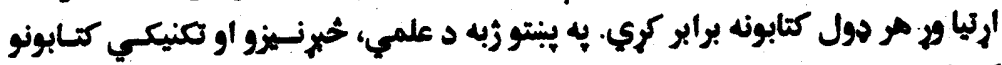

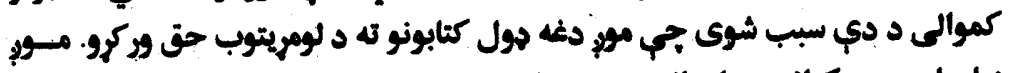

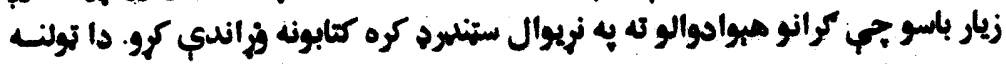

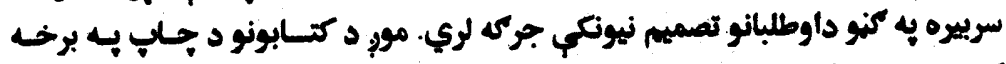

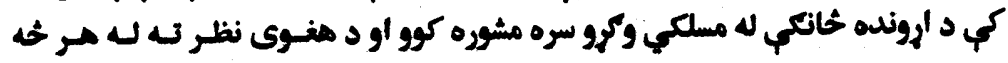
ترجيع وركول كيجي.

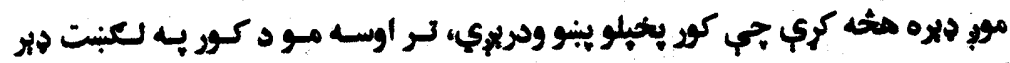

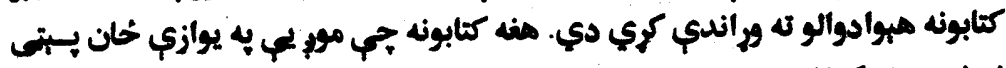

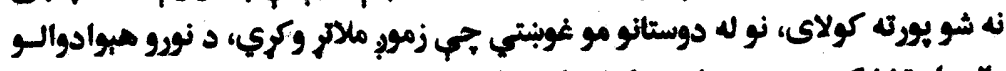

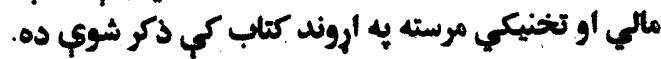

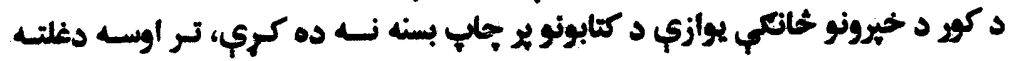

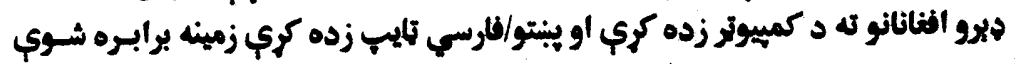

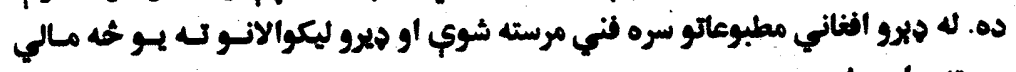
مرسته برابره شوي دها.

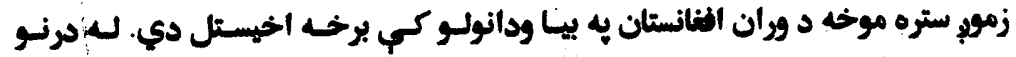

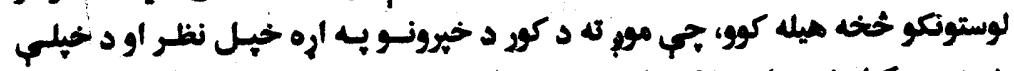

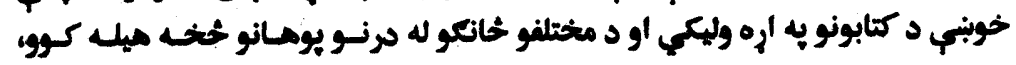

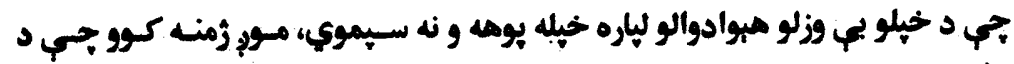

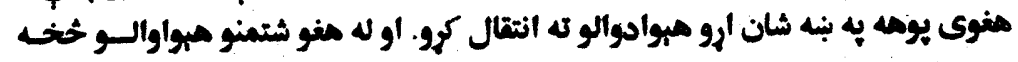

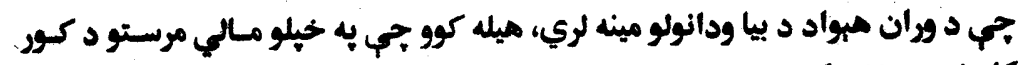
كارونه هميشني كري.

\section{خورا درنبت}

هاكتر محمد فريد بزكي

د كور بنست ايبنودونكمي اواداري مشر فرئ يزي 
ختيز بيا رغوني اداري (كور) د خيرونو خانكي تر اوسه خباره كري دي: 1.

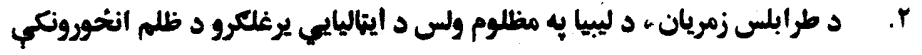
4a"

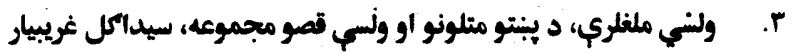

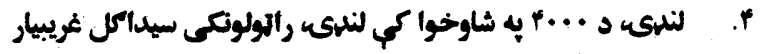

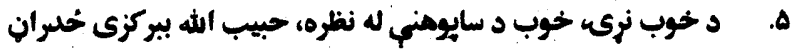

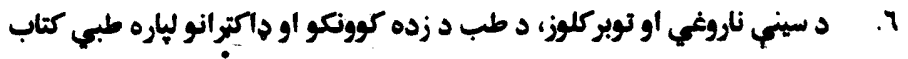

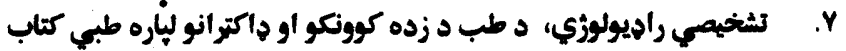

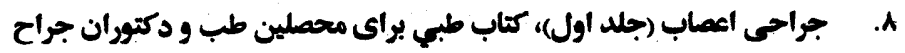

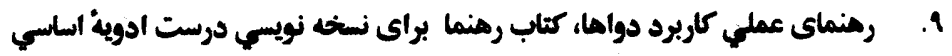
1. 1. The Ethenic Composition of Afghanistan . .11

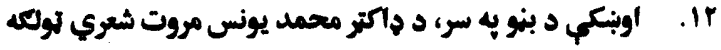

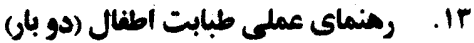

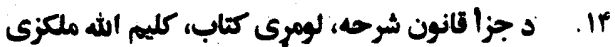

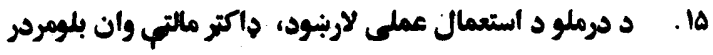
17 . د اينو لار، كاريخي قصه، استاد عبدالنفور بريبنا

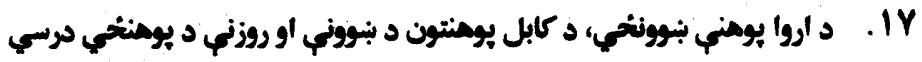
كتاب

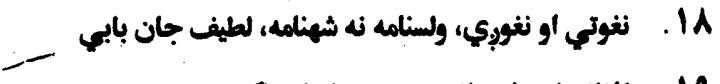

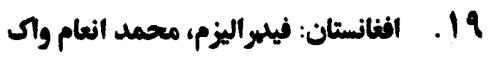

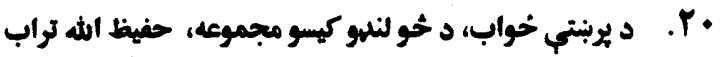

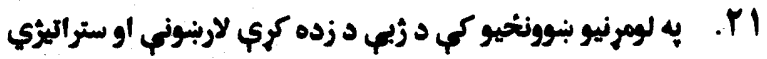

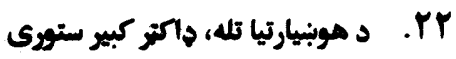

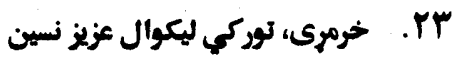

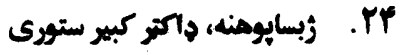

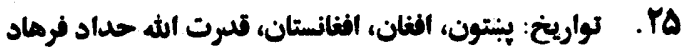

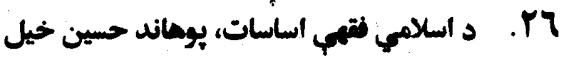


.YY

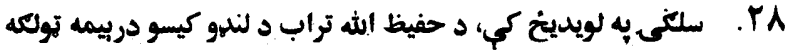

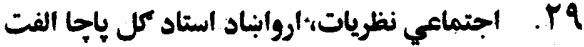
•r. . نشه يانو به إه انتباهي توكه، راتولونكى بادشاه خان شرنوال آץ. به افغانستان كي د قانون جورونب تاريخي بهير rr. ويوه د سايوهنب به رنا كي، داكتر كبير ستورى

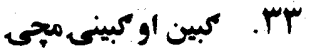

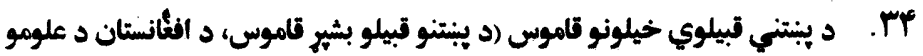
اكاهمس خنّخه كلنه خيرنه).

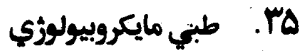
جإ

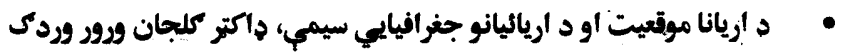

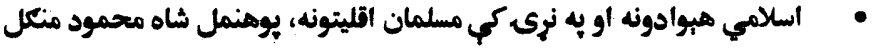

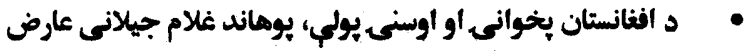
: إنها

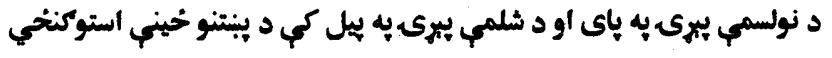

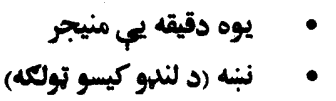

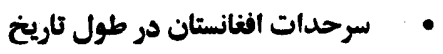
• نخجال او ملمرن ايركانريشن • • • • • •

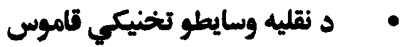

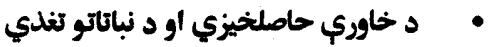

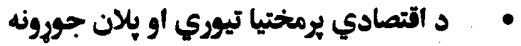

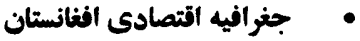

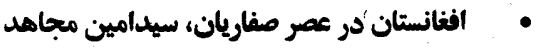
• 


$$
\begin{aligned}
& \text { د خيلو كتابونو د تصحيح، تايب، ريزاين او جابِ لِّاره زموبر سرهبه }
\end{aligned}
$$

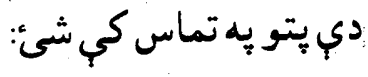

Dr. M. Farid Bazger

G.P.O. Box 607, Peshawar, Pakistan

Tel. +92-91-841280, 845637, 45504 Fax. +92-91-841089

Mobile: 092-0303 7869775

E-mail: kor_bazger@hotmail.com

او يا د دعوت د خيروني له لارب: C/O M.Tariq Bazger

P.O.Box 289, 2001 Lillestrom, Norway

Mobile: +47-90856195

Phone and fax: +47-63844384-85

E.mail: dawatnet@start.no

Website:http://home.no.net/dawatnet 


\section{د ليكوال نهبُْندنه}

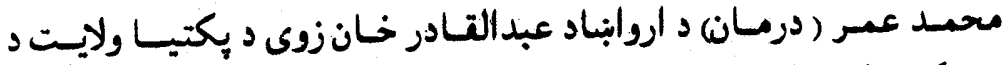

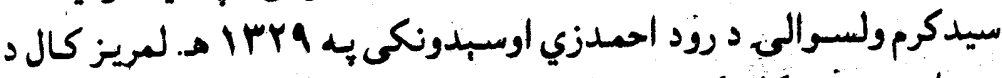

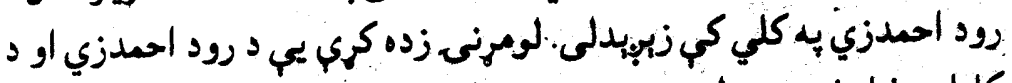

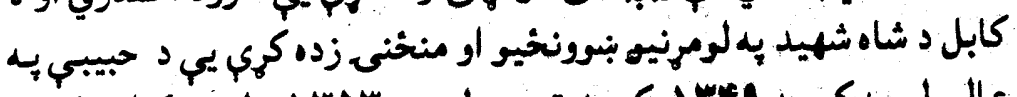

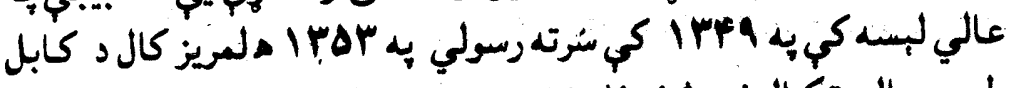

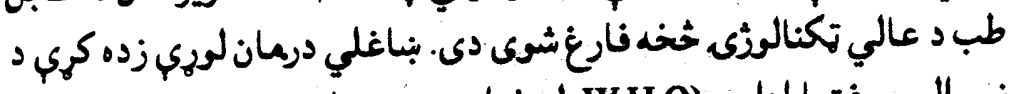

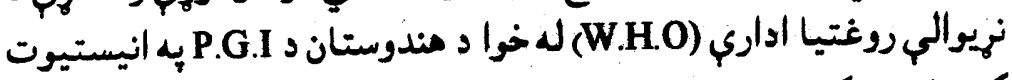
كي بشتري كري.

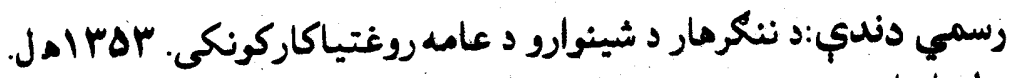

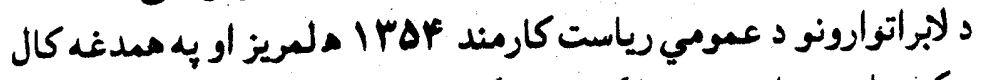

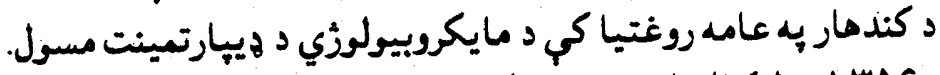

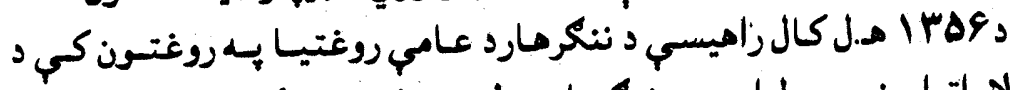

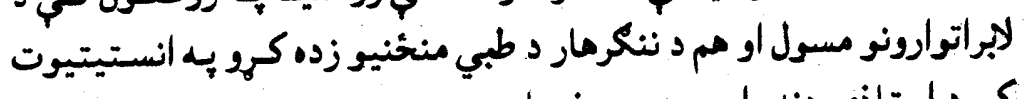
كي د استاذى دنده اوس مم برمخ بيايي.
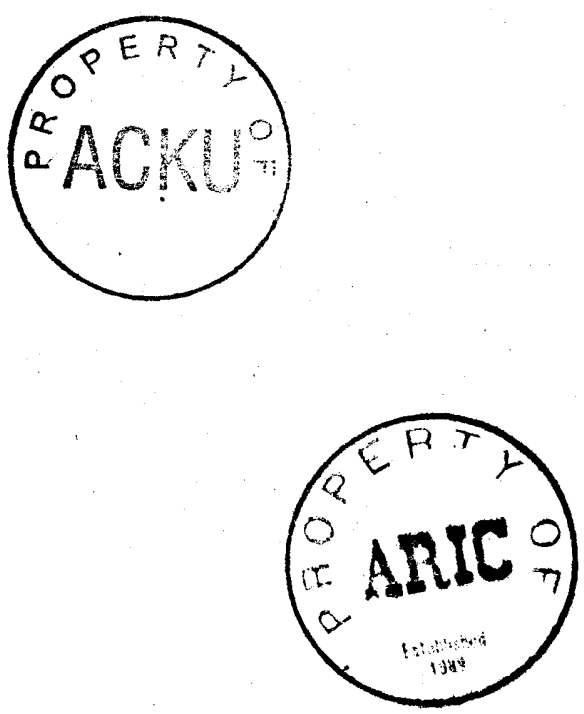
ARIG

B

$6 \cdot 50.7$. shed by:

$D A R$ iz Organization for Rehabilitation (KOR)

11.7.0.9_il: kor_bazger@hotmail.com

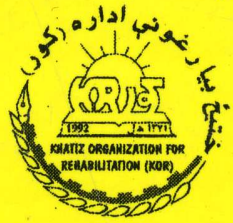

Medical
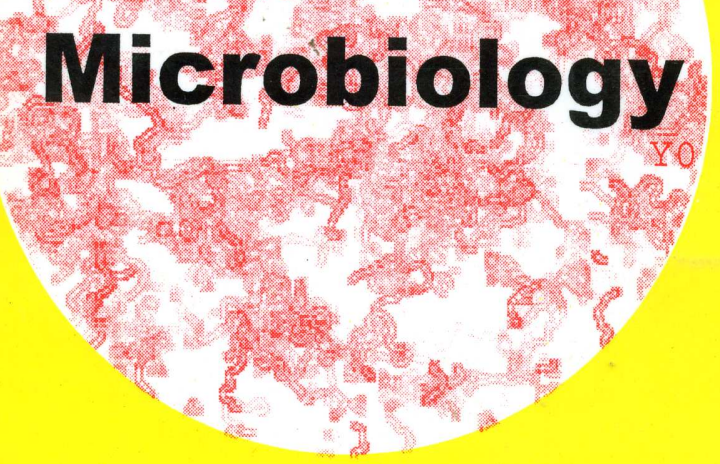

Mohammad Omar Darman 